\title{
LOS TIPOS ANFÓRICOS DEL GUADALQUIVIR EN EL MARCO \\ DE LOS ENVASES HISPANOS DEL SIGLO I A.C. UN UNIVERSO HETEROGÉNEO ENTRE LA IMITACIÓN Y LA ESTANDARIZACIÓN*
}

\section{GUADALQUIVIR AMPHORA TYPES WITHIN HISPANIC CONTAINERS FIRST CENTURY BC. A HETEROGENEOUS UNIVERSE BETWEEN THE IMITATION AND THE STANDARDIZATION}

\author{
ENRIQUE GARCÍA VARGAS** \\ RUI ROBERTO DE ALMEIDA*** \\ HORACIO GONZÁLEZ CESTEROS****
}

\begin{abstract}
Resumen: La dinámica de la investigación actual sobre la cultura material tardorrepublicana y tempranoaugustea en la Ulterior y en el resto de los territorios que constituyeron el Imperio hace que cualquier sistematización de las ánforas fabricadas en el valle del Guadalquivir (en sentido extenso) durante este periodo quede enseguida superada por nuevos hallazgos y materiales. El presente trabajo pretende ser un estado de la cuestión actual respecto al estudio de éstas ánforas del siglo I a.C. que, sin ser exhaustivo, incluya el mayor número de contextos posibles, tanto de las áreas de producción como de las de consumo. Sobre esta base material, se ensaya una ordenación tipológica que incluye diecisiete tipos anfóricos regionales incluidos en cuatro grupos cuyo criterio de formalización es, fundamentalmente, el "éxito comercial" y la duración, mayor o menor de la "vida" de los contenedores que los componen. Al análisis morfológico, que incluye novedosas propuestas de trabajo sobre el origen y el desarrollo formal de tipos como Haltern 70, Oberaden 83 y Urceus, se añade una contextualización histórico-económica y la necesaria confrontación con los repertorios anfóricos contemporáneos de otras áreas productivas peninsulares. El resultado es una propuesta tipológica y funcional compleja que, a nuestro juicio, es la que mejor parece ajustarse al estado actual del conocimiento arqueológico sobre los tipos anfóricos de la Ulterior interna durante el siglo I a. C. Evidentemente, la propuesta se presenta como tema de reflexión y base para la discusión y confrontación de ideas en los próximos años.

Palabras clave: Ánforas, valle del Guadalquivir, República romana, siglo I a.C., tipología
\end{abstract}

\footnotetext{
* El presente trabajo se inserta en el Proyecto "Amphorae ex Hispania: paisajes de producción y consumo" (HAR2011-28244).

** Departamento de Prehistoria y Arqueología, Universidad de Sevilla
}

Abstract: Current research trends on the material culture in the province of Hispania Ulterior in the late republic and the early years of the Augustean reign, make any systematisation of amphorae in the Guadalquivir valley (in a wide sense) liable to be soon superseded by new finds and evidence. The present work aims at reviewing the state of the question of 1 st century b. C. amphorae, not exhaustively but taken as many contexts into account as possible, including production and consumption areas. Starting with the material evidence, we propose a typology divided in seventeen regional amphora types in four groups, according to 'commercial sucess' and the duration of the type. The morphological analysis, which includes new proposals on the origin and development of types such as Haltern 70, Oberaden 83 and Urceus, is offered along a historic-economic contextualisation and the comparison with other coeval amphoric repertoires in the Iberian Peninsula. The result is a complex typological and functional proposal which, in our opinion, responds better to the archaeological record for the chronology and geographical context in hand. Obviously, the proposal aims at becoming the base for further discussion in the future.

Keywords: Amphorae, Guadalquivir Valley, Roman Republic, $1^{\text {st }}$. century B.C., tipology

\footnotetext{
*** Bolseiro da Fundação Para a Ciência e Tecnologia, Universidade de Lisboa - UNIARQ

**** Instituto Catalán de Arqueología Clásica, Universidad Au-
} tónoma de Madrid 


\section{INTRODUCCIÓN Y RAZONES PARA UN ESTUDIO}

La investigación enmarcada en la amplia región productora del Guadalquivir (en cuya cuenca se incluye también la del subsidiario Genil y otros afluentes menores como el Corbones y el Guadaira) viene sufriendo una evolución particular, sobre todo en los últimos 20 años, que no va a la par de la desarrollada en otras grandes zonas productoras, como pueden ser la Bahía gaditana y su hinterland inmediato, la Gallia Narbonense o el cuadrante nororiental de la Hispania Tarraconensis. Observando y analizando ese proceso con alguna distancia, e intentando hacerlo de un modo imparcial (en tanto sea posible), resulta en gran medida lógica la atención e inversión dedicada a los demás ámbitos provinciales.

Podemos decir que gran parte de la investigación dedicada a los temas anfóricos del Guadalquivir es el resultado de una "descentralización" o "despolarización" de los objetos de estudio. En otras palabras, que gran parte de esa investigación, su consecuente evolución y consolidación, se ha realizado fuera del área de producción original, con un elevado número de trabajos y aportaciones centrados en lugares de consumo por todo el mundo romano. El mejor ejemplo y exponente máximo de este paradigma lo representan las excavaciones españolas en el Monte Testaccio en Roma, seguida por una serie interminable de investigaciones y proyectos desde el Finisterre occidental que es el "mar exterior" atlántico, cruzando todo el Mediterráneo hasta llegar a Iudaea, sin olvidarse de las fronteras de Europa septentrional germanas y británica, y de todo el norte de África.

Mientras que en ámbitos como las bahías gaditana $\mathrm{y}$ de Algeciras se ha ido definiendo desde los años noventa del siglo XX y "desde dentro" la evolución de los repertorios cerámicos locales, incluyendo el estudio de los procesos de "romanización" de las morfologías anfóricas (García Vargas 1996; Lagóstena Barrios 1996a; García Vargas 1998; Bernal Casasola (dir) 1998; Lagóstena Barrios y Bernal Casasola (eds.) 2004; García Vargas y Bernal Casasola 2008; Sáez Romero 2008), en el interior del valle del Guadalquivir, la falta de excavaciones y la ausencia generalizada de niveles pre-tiberianos en los escasos alfares excavados (cf. Sáez Fernández y otros 1997), así como de materiales preimperiales en los muchos prospectados (cf. Berni Millet 2008; Barea Bautista y otros 2008) ha ocultado a la investigación durante mucho tiempo las fases más antiguas de producción de las ánforas de la Ulterior tardorrepublicana.
El boom inmobiliario de la primera década del siglo XXI ha permitido, sin embargo, contar con los primeros datos al respecto en la propia zona de producción, poniendo, además, en evidencia, el hecho de que las fases primeras de producción de ánforas de tipología romana en el valle del Guadalquivir tuvieron lugar, a diferencia de la dinámica posterior, en los espacios urbanos o peri-urbanos de las principales ciudades del valle bajo del río como Carmona (la antigua Carmo), Alcalá del Río (Ilipa Magna), Italica y la propia Sevilla (Hispalis) y no prioritariamente en ámbito rural (Chic García y García Vargas 2004; García Vargas 2010) (fig. 1).

En la actualidad, el mundo productivo de las ánforas republicanas de tipología romana del valle del Guadalquivir comienza a delinearse fundamentalmente en torno a dos núcleos de los que proceden la mayor parte de la información arqueológica: Carmona y Sevilla. De la antigua Carmo, en el valle medio del río Corbones, afluente del Guadalquivir, se conoce una importante área de alfares en la zona occidental de la ciudad, inmediatamente extramuros, que se hallaba en funcionamiento hacia los últimos decenios del siglo I a.C. Por su parte, los contextos portuarios de Hispalis arrojan datos de primer orden acerca de la circulación de las cerámicas locales y de importación en la ciudad entre las décadas finales del siglo II y el último cuarto del I a.C. (cf. García Vargas e.p.).

Estos novedosos datos, junto a los proporcionados por contextos cerámicos contemporáneos a los de Carmona y Sevilla, documentados en otros puntos del valle como Italica e Ilipa, la actual Alcalá del Río (García Vargas 2010), permiten hoy por hoy ampliar el conocimiento de las ánforas del Guadalquivir más allá de la consolidada investigación acerca de los tipos "canónicos" y bien conocidos de la región, como son las ubicuas Haltern 70 y, sobre todo, las Dressel 20 béticas.

Una primera aproximación al panorama anfórico del Guadalquivir que incluya las estratigrafías (productivas o no) del propio Guadalquivir, permitirá conocer las grandes líneas de la "evolución" morfológica de las primeras ánforas romanas de la región y, al mismo tiempo, tendrá como resultado "ordenar" y dotar de sentido a los contextos republicanos con ánforas del valle bético conocidos en el resto de la Península Ibérica o fuera de la misma. Estos son los objetivos principales de este artículo, en el que los autores hemos querido que converjan los esfuerzos que cada uno de nosotros hace en un espacio geográfico diferente para la misma época. Pero además, una ordenación del material anfórico republicano del Guadalquivir pretende constituir una aportación meditada a la comprensión de 


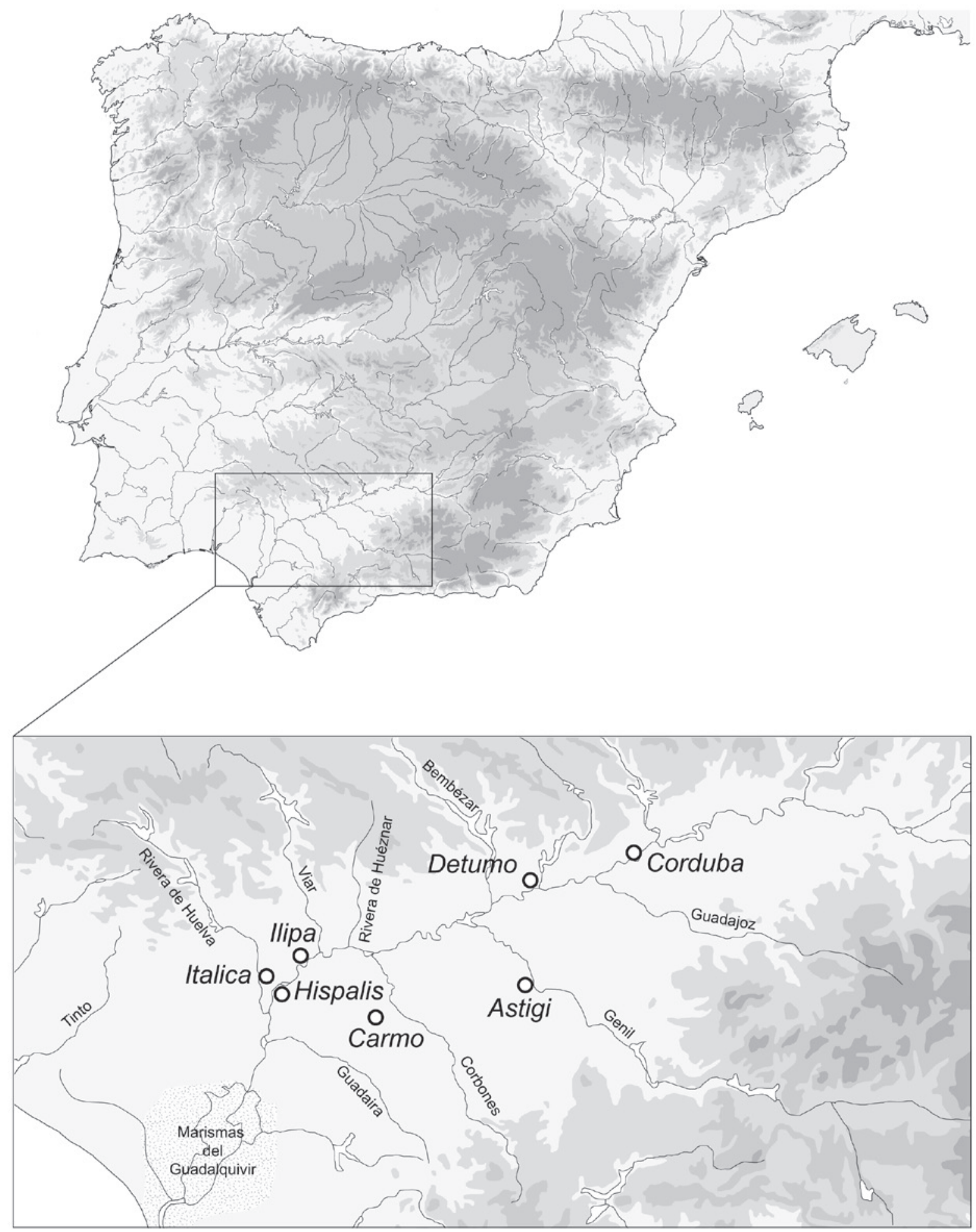

Figura 1. Valle del Guadalquivir y algunos de los principales núcleos urbanos en el siglo I a.C. 
la dinámica económica y artesanal que se encuentra detrás del surgimiento del mismo y para contextualizar su desarrollo hasta la "cristalización" de las morfologías anfóricas imperiales de la región, ampliamente exportadas hacia el Atlántico, el Mediterráneo y la frontera reno-danubiana desde los últimos años del siglo I a.C.

\section{LA ECONOMÍA DE LA ULTERIOR Y EL SURGIMIENTO DE UN REPERTORIO ANFÓRICO PROVINCIAL EN EL VALLE DEL GUADALQUIVIR}

Las alfarerías turdetanas del Valle del Guadalquivir habían venido fabricando una serie de contenedores anfóricos hoy relativamente bien conocidos $(\mathrm{Be}-$ lén Deamos 2006; Ferrer Albelda y García Fernández 2008, con bibliografía anterior) cuyo origen se encuentra en las formas de la tradición artesanal semita. Aunque los centros de producción de estas ánforas turdetanas han sido, en general, escasamente estudiados, pueden señalarse en la actual provincia de Sevilla algunos talleres con cronologías de los siglos V al II a.C., como el del Cerro Macareno, en San José de la Rinconada; el del Albollón, en el núcleo urbano de Carmona; el de Pajar de Artillo, junto al teatro de la ciudad romana de Italica, en Santiponce, y el del Palacio Arzobispal de Sevilla (García Fernández y Ferrer Albelda 2010), la vieja Spal prerromana. Todos tienen en común la ubicación periurbana con respecto a oppida prerromanos más o menos importantes (Chic García y García Vargas 2004: 310-311; Ferrer Albelda y García Fernández 2008: 204) y la fabricación de un repertorio homogéneo de ánforas cilíndricas de cuello indiferenciado y asas semicirculares conocidas en la bibliografía regional como Pellicer B-C y Pellicer D ( cf. Pellicer Catalán 1978). Recientes análisis de residuos orgánicos en el interior de ánforas de la forma Pellicer D procedentes de contextos de los siglos III-II a.C. de Alcalá del Río (la antigua Ilipa Magna) y de Sevilla, sugieren aceite de oliva como uno de los contenidos de esta clase anfórica (García Fernández y García Vargas 2010: 118), lo que indica una "tradición" regional en la producción y puesta en circulación de ánforas olearias. La difusión de estos contenedores no parece, sin embargo, haber superado en mucho los límites geográficos del suroeste peninsular, por lo que suelen considerarse ánforas destinadas a la distribución local o regional de las producciones agrícolas del campo turdetano, si bien en determinados casos, se documenta su presencia en áreas atlánticas relativamente alejadas, como Galicia (Castro de Montealegre, Vigo: González Ruibal y otros 2007: 59) y Marruecos ( Lixus, actual Larache: Aranegui, ed. 2005: 129).

Hacia las décadas centrales del siglo I a.C., un momento en el que las ánforas de tradición prerromana siguen fabricándose y distribuyéndose en cierta cantidad en el valle de Guadalquivir, al lado de éstas últimas comienza a consolidarse en la región (y hasta en los mismos alfares, caso de Carmona) un elenco de tipos anfóricos de morfología plenamente romanizada, cuyos ejemplares más antiguos, imitaciones más o menos fieles de prototipos de la costa tirrénica italiana (las conocidas Dressel 1), se remontan a los primeros decenios del siglo. A diferencia de las ánforas turdetanas, muchos de estos tipos anfóricos del interior del valle del Betis van a conocer una considerable difusión exterior, lo que se ha interpretado tradicionalmente como un indicio de primer orden sobre la expansión agrícola en la región y sobre el papel de la misma en el abastecimiento en géneros alimenticios de los mercados militares y civiles que emergen un poco por todas partes en el Mediterráneo occidental como consecuencia de la conquista romana (Carreras Monfort y Morais, eds 2010).

Aunque la conquista y el control de los territorios hispanos por los ejércitos de Roma desempeñó un papel de primer orden en el "boom" comercial experimentado por las mercancías agrícolas del área interior bética, y aunque una buena parte de este excedente alimenticio estuvo dedicado al abastecimiento de los ejércitos que se esforzaban por controlar a beneficio de la República romana las áreas interiores de la Península, resulta evidente que el abastecimiento militar no debe considerarse en exclusiva como la causa de este "despegue" económico regional.

El gran esfuerzo militar realizado tras la parte de la guerra contra Cartago que se libró en suelo peninsular, continuó prácticamente sin pausa hasta las guerras de la cornisa cantábrica ya en época de Augusto. A las continuas guerras de conquista, materializadas principalmente en el conflicto celtibérico-lusitano (154-133 a.C.), hay que sumarle las operaciones de control y sometimiento de las poblaciones vencidas, y las guerras civiles que desde Sertorio a la batalla de Accio tienen en Hispania uno de sus campos de acción principales. Los contextos militares del siglo II y del primer tercio del I a.C., nos muestran que, en estas fechas, el abastecimiento de mercancías en ánforas para las tropas en combate se hace desde la costa púnica hispana y africana y, sobre todo, desde la Italia tirrénica. El mismo panorama muestran los contextos "civiles" de consumo en ciudades como Hispalis, o Ilipa (Alcalá del Río), 
donde los contextos del último cuarto del siglo II y las primeras décadas del I a.C. (García Vargas y García Fernández 2009) están dominados aún por los contenedores campanos del tipo Dressel 1A, seguidos a distancia por las salazones gaditanas (tipos 7.4.3.3. y 9.1.1.1) y por los vinos y aceites itálicos (Lamboglia 2 y tipos ovoides brindisinos). Sin embargo, ya a principios del siglo I a.C., hacen su aparición, en la propia Sevilla y en otros lugares del interior de la región como la mina de La Loba (Fuenteovejuna, Córdoba: Blázquez y otros 2002), las primeras Dressel 1 de fabricación local que parecen preludiar un abastecimiento regional cuyo máximo no se alcanzará hasta al menos, mediados o el tercer cuarto del siglo I a.C. (García Vargas 2010: 65).

Otro de los factores que incidió decisivamente en la creación de una economía agraria excedentaria, orientada a la exportación y al abastecimiento de las necesidades del estado romano, fue la demanda que se creó en las minas del sur y del levante peninsular. Ya desde finales del siglo II o principos del I a.C., las amonedaciones del grupo de cecas que emite con una " $A$ " en el reverso (Chaves Tristán y García Vargas 1994: 384385), grupo integrado por Ilipa (Alcalá del Río, Sevi1la), Ituci (Tejada la Nueva, Paterna, Huelva), Laelia (Cerro de la Cabeza, Olivares, Sevilla) y Caura (Coria, Sevilla), y también por Onuba (Huelva) y Myrtilis (Mértola, Portugal), ya fuera del Bajo Guadalquivir, parecen indicar la existencia de una relación estructural entre estas ciudades y las grandes rutas de salida del mineral del Cinturón Pirítico luso-onubense-sevillano, a través de las cuencas del Guadiana (Mirtylis), el Tinto (Onuba e Ilipa), el Guadiamar o Menoba (Ituci y Laelia) y el Guadalquivir (Caura e Ilipa). Dicha relación, habla bien a las claras del hecho de que, tras los últimos episodios de innestabilidad en la región ligados a las consecuencias de las guerras lusitanas, el "esqueleto" administrativo y comercial de la región minera del Suroeste está perfectamente diseñado (García Vargas y otros 2008: 252-253). Es probable que entre los “itálicos" que según Diodoro (5.36) se abalanzaron ahora sobre las minas de Iberia, atraídos por las posibilidades de negocio en la región e impulsados igualmente por la convulsa situación en la Península Itálica, se encontraran no sólo personas interesadas en el trabajo directo en las minas, sino también un buen número de emprendedores dispuestos a aprovechar las oportunidades de ganancia que la circulación del dinero estaba abriendo en el ya no tan lejano Occidente (Chic García 2008a: 341).

Los trabajos recientes de J. A. Pérez Macías y A. Delgado Domínguez (2007; 2011) están poniendo en evidencia una explotación republicana e imperial inicial más amplia de lo esperado en los yacimientos de mineral de plata del área de Riotinto, controlada desde castella con guarnición militar como el de El Castillejo (El Campillo, Huelva: Pérez Macías y Delgado Dominguez 2011: 48-56) que en tantos aspectos se asemeja al del Castelo da Lousa (Mourão: Alarcão y otros 2010) y que vuelve a poner sobre el tapete el controvertido tema de las "casa-fuerte".

Con independencia de que se trate de establecimientos de defensa del territorio o de casas-fuertes de funcionalidad agrícola y ganadera (cf. Moret y Chapa eds. 2004) vinculadas a la explotación del territorio, la nueva realidad territorial que surge a principios del siglo I a.C. en torno a las áreas mineras debe llamar la atención hacia el hecho de que los desarrollos económicos de estos momentos estaban poniendo las bases de una red de aprovisionamiento y circulación de bienes envasados en ánforas que quedaba regularizada a través de las mismas ciudades, en cuyas manos se encontraba no sólo el control de los recursos y de las vías de comunicación, sino también, la gestión de los "medios de pago" de un "entramado comercial" que comenzaba a demandar abundante numerario, no tanto para financiar los tráficos como para hacer frente a las numerosas transacciones menores y pagos de servicios (Chaves Tristán y García Vargas 1994) que un mundo económico en desarrollo precisaba. Recientemente, F. Chaves Tristán $(2005,2008)$ ha caracterizado el siglo I a.C. hasta el comienzo de las Guerras Civiles en la Península como una época de transición en la que las acuñaciones ciudadanas hispanas (es decir, las comunidades que están tras ellas) comienzan a mostrar un cierto interés por la imitación de tipos y patrones monetales, incluidos los motivos ideológicos que traslucen los primeros. La autora, no duda en calificar estos motivos ideológicos como claramente itálicos, lo que, al igual que la imitación de tipos cerámicos, especialmente

1. El sistema de organización y control territorial planteado para los territorios mineros meridionales, puede extenderse a otras regiones peninsulares, como ciertas áreas de la Tarraconense. Un ejemplo similar lo tendríamos en la zona de Tarraco, donde dicha ciudad actuaría como puerto de recepción de mercancías, tanto de su propio ager como de otras regiones mediterráneas, y donde está documentada la presencia de una serie de "casas-fuertes" que defenderían los pasos interiores hacia la zona ilergeta o el valle del Ebro. Uno de estos establecimientos de carácter militar parece ser el castellum de Puigpelat (Alt Camp), en el que junto a una buena importación de ánforas itálicas y tarraconenses, se ha podido constatar la presencia de algunas béticas costeras y de una Ovoide 5 con las típicas pastas del valle del Guadalquivir, anteriormente clasificada como Dressel 12 (Díaz García, 2010, fig. 42, 4). 
anfóricos, apunta hacia el papel creciente de los elementos de procedencia italiana en la región.

A partir de esta primera romanización efectiva que incluyó, como se ha indicado, los primeros ejemplos de una ocupación del paisaje a la romana, las evidencias de la presencia de elementos romanos civiles o militares, que necesitaban de un abastecimiento adecuado en alimentos elaborados, no hace más que ampliarse a lo largo del siglo I a.C. De hecho, la activa participación de ciudadanos romanos residentes en la Ulterior en el contexto de las guerras civiles que enfrentaron a pompeyanos y cesarianos hacia mediados del siglo I a.C., muestra una situación "étnica" que incluye ya claramente a comunidades de romano-itálicos con fuertes raíces en la región. En un contexto económico y cultural en el que el estatus de una persona dependía de su capacidad para adquirir y cultivar tierras, no es descabellado pensar que una buena parte de aquellos negociantes itálicos, unidos a soldados asentados en la región y a aquéllos que de una u otra manera habían adquirido la ciudadanía romana, habían acabado ingeniándoselas para establecerse como possessores en las escasas ciudades privilegiadas de Hispania o en los más numerosos conuentus ciuium Romanorum establecidos en los oppida peregrinos. Hacia mitad del siglo I a.C. debieron ser ya tantos como para que fuera posible reclutar una legión vernacula (creada hacia 55-52 a.C. según Marín Díaz 1988: 176) cuyos integrantes, como era de esperar, tenían domicilium aut possessiones in Hispania (Bellum Ciuile, 1.86.3). Que una buena parte de estos legionarios hispanienses eran naturales del sur de Iberia se deduce del hecho de que en el contexto de la rebelión contra el gobernador cesariano de la Ulterior, Q. Casio Longino, "no había entre los (romanos) nacidos en la provincia, ni entre los soldados de la legión vernácula, ni entre los que la asiduidad (en la región) había ya hecho provinciales... nadie que no coincidiera con toda la provincia en el odio a Casio"(Bellum Alexandrinum, 53.4); de modo que parece lógico concluir (García Vargas 2001: 106-107) que debe haber sido en el entorno de los conuentus ciuium Romanorum del valle del Guadalquivir donde surgieron a lo largo del tercio central del siglo I a.C. la mayoría de los tipos anfóricos "italianizantes" que, en su conjunto, constituyeron el repertorio formal a partir del cual "cristalizaron" las morfologías regionales en época tempranoimperial (García Vargas 2009).

Aunque parece claro que fueron acontecimientos como la guerra sertoriana los que provocaron un primer incremento considerable de la capacidad productiva de la Ulterior con vistas a abastecer las tropas en combate: Fabiao 1989), la discusión acerca de si el abastecimiento anfórico en el sur de Hispania a estas alturas de siglo tuvo carácter civil o militar carácter civil o militar es, en cierto sentido, una falsa polémica. En primer lugar, porque la presencia militar en el suroeste no se restringe a los momentos de tensión bélica. J. A. Pérez Macías y A. Delgado Domínguez (2007: 123-130) han propuesto un sistema organizativo del coto minero de Riotinto en torno a vici mineros, vías de comunicación y puestos de control militar o castella desde época de Augusto-Tiberio (un momento en el que supuestamente la Provincia Bética era inerme como corresponde a un territorio de la administración senatorial), aunque es probable que la emergencia de este sistema se esté gestando ya a mediados del siglo I a.C., y que incluso acabe sirviendo de referencia para la organización de otros saltus mineros importantes como los de Panonia-Mesia Superior (Dušanić 1989). En segundo lugar, porque la actuación administrativa y organizativa del ejército en los cotos mineros borra en cierto sentido las diferencias entre la administración civil y la militar en un territorio en el que la ausencia de ciudades requería de la coordinación de esfuerzos para mantener en funcionamiento las delicadas infraestructuras mineras. Y en tercer lugar, porque el abastecimiento a los cotos mineros se debía organizar de forma centralizada a partir de los territorios urbanizados colindantes con los saltus, desde cuyos oppida se vehicularía el transporte de materias primas (madera, instrumental férrreo, etc.), productos de consumo básico (cereal, aceite en ánforas olearias) y de "prestigio" como los vinos y las salazones envasadas en ánforas (Chic García 2008b).

Desde fines del siglo II a.C. existe una correspondencia casi exacta entre las importaciones anfóricas que alcanzan las áreas mineras y los registros cerámicos de los oppida turdetanos y de las incipientes ciudades romanas de la zona. Las coincidencias formales entre los registros de Hispalis, Ilipa o Italica hablan, pues, a las claras del carácter portuario y distribuidor de estos establecimientos urbanos con respecto a los cotos mineros más o menos cercanos. Hacia mediados del siglo I a.C. la red de distribución de las ánforas romanas producidas en el valle del Guadalquivir alcanza también las áreas mineras del Mondego y el Tajo, donde se observa un cambio importante de las estrategias de control territorial a partir del periodo de gobierno de César en la Ulterior (ha. 61 a.C. cf. Fabião 2004a: 60), una época que estuvo presidida para el futuro dictador por el interés de éste en abrir nuevas rutas hacia los centros atlánticos de distribución de metales (Brigantium, en este caso. Cf. Chic García 1995). Aunque este 
esfuerzo puede considerarse relativamente fracasado hasta la culminación de la tarea en la futura conquista de la Galia libre por parte del propio César, lo cierto es que los movimientos de romanos y gaditanos (representados por Balbo, praefectus fabrum de Cayo Julio César en esta aventura militar por el Atlántico peninsular) debieron abrir para la administración romana los ricos recursos auríferos de la región del Mondego, y posiblemente también del Tajo, en el cual, una vez ya controlada la principal urbe de su desembocadura (Olisipo), se consolida la presencia romana en el área de su cuenca baja, donde la ciudad de Scallabis (Santarem) emergiría como importante centro regional en sustitución de Chões de Alpompé (¿Moron?: Fabião 2004a: 60).

Los repertorios anfóricos de establecimientos militares como el de Lomba do Canho (Arganil, fechado en el tercio central del siglo I a.C.: Fabião 1989) o la Alcáçova de Santarém-Scallabis (Almeida 2008) están estrechamente emparentados en lo que se refiere a su repertorio de ánforas del Guadalquivir, evidenciando un importante movimiento de mercancías alimentarias de esta procedencia justo en el momento en el que los cotos mineros del centro-norte de la costa portuguesa comienzan a ponerse en funcionamiento. También aquí se repite un esquema de ocupación militarizado, basado en la presencia de campamentos y castella cuyo abastecimiento no es más que el flujo principal de unos movimientos de mercancías que alcanzaron sin duda los establecimientos civiles de igual modo que los militares, y cuya demanda en ánforas béticas era a la vez causa y consecuencia de la prosperidad regional de las campiñas del Guadalquivir y del Guadalete, así como de la costa del Estrecho (cf. Fabião 2001).

\section{PANORAMA ARQUEOLÓGICO Y ESTADO DE CONOCIMIENTO ACTUAL SOBRE LAS ÁNFORAS DEL GUADALQUIVIR ENTRE EL FINAL DE LA REPUBLICA Y EL INICIO DEL PRINCIPADO}

\subsection{Los tipos del Guadalquivir: propuesta cronológica, tipológica y funcional}

Hace tan sólo unos años, las ánforas republicanas del Guadalquivir eran absolutamente desconocidas, y por lo tanto obviadas en los estudios sobre economía productiva y comercial de la Hispania preimperial. Se aceptaba una cierta "profundidad" cronológica en algunas producciones imperiales, como las Haltern 70, forma a la que se asignaba un ejemplar nunca publicado del pecio de la Madrague de Giens que se fecharía en la primera mitad del siglo I a.C. (Tchernia 1990). Pero sólo el tipo Clase 67/Lomba do Canho 67 encontró una definición adecuada en los estudios anfóricos gracias a los trabajos de C. Fabião (1989) en el yacimiento homónimo, de J. Molina Vidal (1995; 2001) al respecto de hallazgos y localizaciones del Levante peninsular y de J. Boube (1979-1980; 1987-1988) para las producciones autóctonas documentadas en la costa marroquí y en el yacimiento de Sala (Chellah, Marruecos), que hacen que estas ánforas hayan recibido la denominación alternativa de Sala I. Fue el trabajo de C. Fabião en el Congreso Ex Baetica Amphorae (2001) el que abrió definitivamente el "espacio tipológico" a una serie de contenedores republicanos del Guadalquivir independientes de las Haltern 70 y que, si bien inicialmente agrupados en la propuesta de un tipo o Clase 24 siguiendo la tipología de Peacock y Williams (1986), finalmente han sido "desdoblados" en varios tipos "ovoides" de la Ulterior por R. de Almeida (2008) y analizados por el mismo autor en el contexto de las producciones republicanas del valle bético (cf. Almeida 2010). Con los añadidos y matices propuestos por E. García Vargas (2010 y e.p.), es este mismo universo de producciones republicanas del Guadalquivir (ovoides o no) el que nos proponemos reexaminar en este trabajo contando con los últimos hallazgos y aportaciones conocidos (González Cesteros e. p.; Almeida 2010; García Vargas 2010).

Junto con la articulación temporal propuesta por E. García Vargas (2010 e.p.), fundamentada en la cronología de las producciones y dividiéndolas en un periodo de formación, otro de consolidación y uno definitivo de expansión, proponemos ahora una clasificación complementaria basada en la repercusión que tuvieron los distintos envases republicanos del Guadalquivir, ya que pensamos que en cierta medida éste fue un proceso "selectivo" en virtud del cual únicamente perduraron un conjunto restringido de tipos que son los que constituyeron la base sobre la que "cristalizó" el repertorio regional en circulación durante época imperial.

\subsubsection{Primer grupo. Contenedores precedentes con demostrado éxito provincial}

Si bien los tipos republicanos de la Ulterior de mayor personalidad y de acreditado "éxito comercial" fueron los producidos a partir de las décadas centrales del siglo I a.C., no deja de ser cierto que su aparición no se hizo en un vacío tipológico. La producción regional 
de ánforas se remonta a fechas muy anteriores en el tiempo (Belén Deamos 2006; Ferrer Albelda y García Fernández 2008), aunque a partir de principios del siglo I a.C. se observan algunas modificaciones en las tradiciones artesanales implicadas en la configuración de las formas anfóricas del valle del Guadalquivir. Así, mientras una parte de las producciones regionales de morfología turdetana aparentemente continúa hasta época de Augusto (infra), otra parte de los contenedores que se comienzan a fabricar, seguramente en los mismos alfares, denuncia un proceso complejo de cambio tipológico que asimila morfologías exteriores y que, en buena medida, se limita a imitar más o menos fielmente, tipologías externas exitosas en el Mediterráneo occidental y, por ello mismo, frecuentes en los "mercados" locales y regionales, donde llegaban de la mano de mercatores y negotiatores romanos o romanizados, para satisfacer la demanda local de vinos, salazones y aceite, sobre todo de los dos primeros .

Las "tradiciones" alfareras que sirvieron de referencia a este movimiento de "imitación" de morfologías exteriores fueron la púnica-gadirita y la romano-itálica, responsables de una buena parte de los contenedores en circulación en la zona durante la primera mitad del siglo I a.C. y vehiculadas seguramente por agentes comerciales de las mismas procedencias étnicas que los productos con que traficaban (lo que no significa necesariamente que cada grupo de comerciantes trabajara sólo con los productos de su propio origen). Resulta curioso que áreas "imitadoras", como la bahía de Cádiz (cf. García Vargas 1996) sean al mismo tiempo imitadas en sus producciones, pero en el fondo nos encontramos ante la configuración de un mercado en proceso de estructuración en el que las mercancías de diversa calidad y origen exigen una cierta diferenciación formal, sobre la que ignoramos qué pesó más, si el carácter del producto contenido en el ánfora o el "público" preferencial al que éste iría dirigido. Como quiera que sea, estas primeras imitaciones tendrán escasa perduración como morfologías diferenciadas y, a excepción de los tipos de tradición turdetana, serán sustituidas antes de la mitad del siglo I a.C. por otras ánforas diferentes, esta vez "inspiradas" en tipologías exitosas antes que fieles imitadoras de repertorios externos.

\section{Pellicer D (T.4.2.2.5) (fig. 2)}

La Pellicer D es un contenedor de transporte que responde a las características formales de las ánforas de tradición turdetana, derivadas a su vez, de prototipos fenicios imitados en la región durante la Edad del Hierro. En particular, las Pellicer D parecen sustituir a las también turdetanas Pellicer B-C (García Vargas y García Fernández 2009: 148). Ninguno de los contextos productivos de la Turdetania fechados entre fines del siglo V a.C. (Cerro Macareno-Fernández Gómez y otros 979; Ruiz Mata y Córdoba Alonso 1991) y fines del IVprincipios del III a.C. (Itálica-Luzón Nogué 1973; Carmona, Albollón-Belén Deamos 2006) se asocia con claridad a fallos de cocción del tipo Pellicer D (Belén Deamos 2006: 237-240), aunque sí a evidencias de producción de su "predecesora" la forma Pellicer B-C, lo que invita a revisar los contextos de consumo que han servido de base para darle una datación inicial a las Pellicer $\mathrm{D}$ a fines del siglo IV. Es probable, por tanto, que se trate de un contenedor surgido durante la primera mitad del siglo III a.C. en el Guadalquivir y no antes de la mitad de esta centuria en la bahía de Cádiz (cf. Niveau de Villedary y Mariñas 2002: 239-240 y nota 8.). Se asume, por tanto, una dualidad de producciones de la misma forma en talleres del Guadalquivir y de la costa atlántica, sin que hasta el momento se haya asignado con claridad la producción de este tipo a ninguno de los talleres gaditanos conocidos. Recientes trabajos dejan, sin embargo, pocas dudas (Sousa y Arruda 2010: 959) acerca de la procedencia gaditana de un grupo de estos contenedores y añaden, además, la posibilidad de una serie local "algarvia" de la forma. Por contra, se desvanece de momento la serie marroquí que ha sido propuesta a partir de los trabajos de M. Ponsich (1969) en la alfarería de Kouass, en Arcila, pues los estudios más recientes no aseguran una pertenencia local para los ejemplares de la forma detectados en este establecimiento (Aranegui y otros 2004: 366, Kbiri Alaoui 2007: 66).

De todas las producciones turdetanas prerromanas, las Pellicer D (Pellicer Catalán 1978) serán las únicas que continúen produciéndose después de la conquista del territorio por Roma. Como se ha indicado, la forma fue probablemente también fabricada en alfares del área de influencia púnica gadirita, siendo frecuente en el Castillo de Doña Blanca (Niveau de Villedary y Mariñas 2002), Castro Marim, en el Algarve portugués, donde, como se ha señalado, se propone una producción tardía del tipo (Arruda y otros 2006b: 171 , con reservas) recientemente puesta en duda (Viegas 2011: 498). En Doña Blanca es omnipresente a lo largo de la segunda mitad del siglo III a.C., pero su presencia se documenta de forma masiva en el II y todo el I a.C. en la costa atlántica andaluza, costa atlántica e interior portugués (Sousa y Arruda 2010), costa occidental gallega (González-Ruibal y otros 2007: 51-52) y 


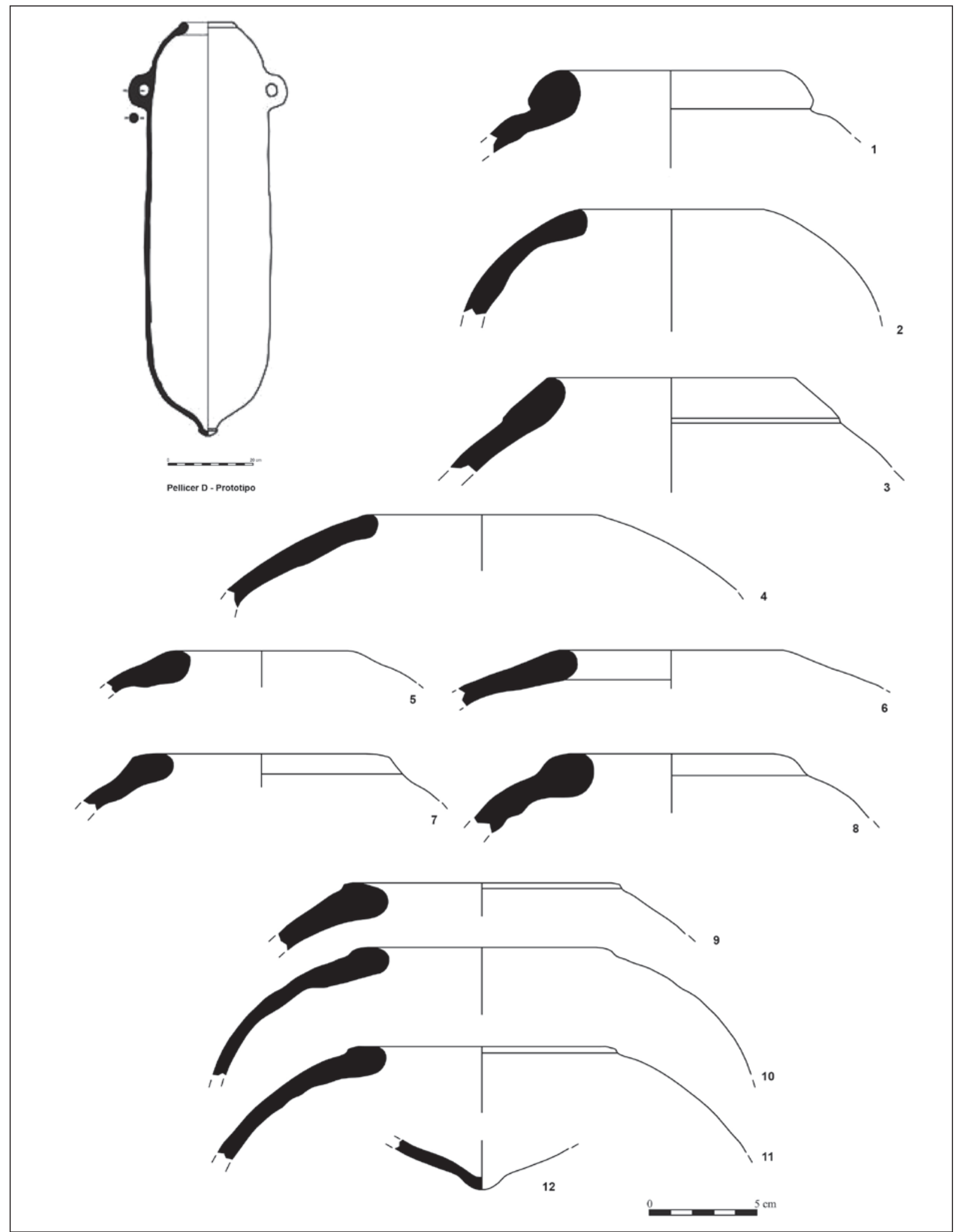

Figura 2. Pellicer D. Prototipo y fragmentos producidos en el Guadalquivir. 1-2: Alcázar de Sevilla fase I; 3-5: Alcázar de Sevilla fase II; 6: Sevilla, Calle Alemanes No 7-9; 7-12: Carmona, calle Dr. Fleming no 13-15. 
marroquí (Lixus: Alaoui y otros 2001: 160), además de en el interior del valle del Guadalquivir (García Vargas 2010; García Vargas e.p.).

Se trata de un ánfora tubular con borde entrante indiferenciado de la pared del cuerpo, excepto por una línea o resalte exterior que tiende a desaparecer desde fines del siglo II a.C., al igual que lo hace el engrosamiento interior del borde que caracteriza las producciones más antiguas. Los ejemplares del siglo I a.C. tienden, por tanto, a presentar bordes que son la continuación de la pared del recipiente redondeada en su extremo, aunque en determinados contextos productivos, como el alfar de la calle Doctor Fleming 13-15 de Carmona (ca. 30-20 a.C.: .: Conlin y Ortiz Navarrete, e.p.), donde conviven con formas claramente romanas, se observa la continuidad de rasgos "arcaizantes", como la carena superior del borde (que a veces es plano en su parte superior) y el engrosamiento interior. El resto de la morfología del ánfora resulta inalterada, con excepción de algunos ejemplares como los denominados Castro Marim I, que presentan una ligera carenación en el tercio superior del cuerpo que gira manteniéndose horizontal hasta el borde, otorgando a la parte alta del ánfora una morfología característica. Las asas son de "oreja", del tipo púnico, y los pivotes un simple botón que culmina un fondo ojival.

En contextos de consumo, como el Patio de Banderas del Alcázar de Sevilla, conviven variantes antiguas de bordes con otras muy evolucionadas. Las primeras predominan, como es lógico, en los contextos de la primera mitad del siglo I a.C. (UEs 1919, 1713), donde, sin embargo ya están presentes los bordes simples, mientras que las segundas son más frecuentes en los del tercer cuarto del siglo I a.C. (UEs 1682, 1692), donde las formas antiguas de borde son tan frecuentes, que apenas puede hablarse de residualidad.

A pesar de la perduración en el tiempo de algunos tipos de ánforas turdetanas, puede decirse que es dentro de la primera mitad del siglo I a.C. cuando, en el interior de la provincia, la tradición productiva "turdetana" (a falta de mejor designación), menos marcada que la tradición púnica en el litoral, se vio profundamente alterada con el inicio de la reproducción y manufactura de contenedores de morfología claramente romana. Asimismo, importa destacar que, por lo menos a lo largo de la segunda mitad del siglo I a.C., van a convivir estas dos familias de formas, "turdetanas" y romanas, reproduciéndose en cierta medida escenarios y dinámicas productivas semejantes a las observadas para la bahía gaditana y de Algeciras, así como para la costa de Málaga, aunque en nuestro caso con valores tal vez más reducidos (infra).
El fin de la producción de las Pellicer D debe situarse poco antes del cambio de era, momento a partir del cual deja de documentarse en los lugares de consumo habituales, sin que tampoco convivan ya con las Haltern 71 de época augustea tardía o tiberiana en los centros de producción (Sáez Fernández y otros 2001). Sí convive durante un breve período de tiempo ( ca. 3020 a.C.) en los alfares tempranoaugusteos de Carmona con Haltern 70 "iniciales" y otros tipos minoritarios del Guadalquivir, como demuestran los abundantes fallos de cocción de talleres como el excavado en la calle Doctor Fleming 13-15 de esta localidad sevillana (García Vargas 2010; García Vargas, e.p.). Hacia el cambio de era, los fragmentos de Pellicer D en los yacimientos del Guadalquivir son terminales o residuales, desapareciendo antes del boom del aceite bético que es un fenómeno augusteo y, sobre todo, julio-claudio.

\section{Dressel 1 (fig. 3)}

A lo largo del siglo I a.C. varias fueron las regiones que comenzaron a fabricar contenedores que reproducían la Dressel 1, el modelo vinario itálico, entendiéndose tal mecánica como la primera manifestación evidente de un proceso de romanización del artesanado cerámico de transporte. Este fenómeno, que se procesó con ritmos que no fueron siempre coincidentes en las distintas zonas, ni tampoco tuvieron los mismos grados de éxito o de aceptación en los mercados locales primero, y supra-regionales después, únicamente se puede observar en zonas que tenían ya una tradición de fabricación de ánforas, aunque estaba formalmente enraizada en las tradiciones artesanales locales (Fabião, 1998: 178), mediante tipos llamados "prerromanos", que se siguieron fabricando conjuntamente con los itálicos durante algunas décadas más (García Vargas 2010; García Fernández y García Vargas 2009; García Vargas e.p.).

El volumen de información del que hoy disponemos, especialmente al nivel del consumo, confirma plenamente el planteamiento hecho hace ya algunos años, según el cual a finales del primer cuarto del siglo I a.C. habría ocurrido en el valle del Guadalquivir un verdadero fenómeno de "romanización de los contenedores", más que una reorientación de las actividades productivas en favor de nuevos productos. Las Dressel 1 son el ejemplo más notorio de esta nueva coyuntura productiva y mediante su producción se intentó sacar partido de una forma de demostrado éxito relacionada con un contenido específico: el vino (Fabião 2001: 667). Las 
imitaciones de esta forma, o mejor dicho formas, de contenedores vinarios contemporáneos, oriundos de las costas tirrénicas de la Península Itálica fueron, a semejanza de la bahía de Cádiz o de Algeciras, las primeras formas en ser tempranamente producidas y exportadas desde el Valle del Guadalquivir (Fabião 2001; García Vargas 2001; García Vargas y Bernal Casasola 2008; García Vargas 2010; García Vargas e.p.). Esa mecánica es la que se puede verificar también para la tarraconense oriental (Comas i Solá 1987; Miró 1988; López Mullor y Martín Menéndez 2007; López Mullor y Martín Menéndez 2008).

Creemos que la discusión sobre la poca solidez, y consecuente rechazo, acerca de la existencia de una Dressel 1 meridional hispánica, por asociación directa la del Guadalquivir, y de la posibilidad de que estas pudiesen ocultar un prototipo muy antiguo de la Dressel 12 (Étienne y Mayet 1995; Hesnard 1998: 293) ya no tiene actualmente razón de ser. En primer lugar, y sin que pretendamos valorar excesivamente la línea puramente evolucionista, el hecho de que en la bahía de Cádiz se documenten a lo largo del siglo II a.C. imitaciones locales de ánforas grecoitálicas (Bustamante Álvarez y Martín-Arroyo Sánchez 2004; Bernal Casasola y otros 2003; Sáez Romero 2008: 574-580) -ánforas que se consideran en sus lugares de producción original como las antecesoras tipológicas de las Dressel 1- dándose además el caso de que en los hornos de San Fernando se documenaen en torno a fines de esta última centuria, formas de transición entre grecoitálicas tardías (Will E similes) y Dressel 1A de imitación que parecen sugerir una transición "reglada" y consecuente al tipo Dressel 1 "clásico", en un proceso en todos los aspectos idéntico al operado en las regiones alfareras originarias. Según esto último, estaríamos ante el surgimiento de la reproducción o copia de este último envase, con toda su serie de variaciones y detalles morfológicos inherentes, más que ante el paso a una forma novedosa, la Dressel 12, basada supuestamente en la anterior, sin que existiese un proceso de asimilación y/o reproducción del mismo. Por otra parte, a nuestro juicio, la existencia en paralelo de series de imitaciones de Dressel 1 litorales y del interior viene a poner de manifiesto el propósito de realizar auténticas imitaciones de estas ánforas itálicas.

Es cierto que las piezas hasta ahora conocidas y manufacturadas en el valle del Guadalquivir parecen carecer de una estandarización mínima, tanto en la forma como en las dimensiones, por lo que suelen presentar detalles y morfologías singulares. Con todo, si ante la presencia de fragmentos aislados pueden caber dudas de que se trate de otro tipo de envases, la observación conjunta de bordes -con sus variadísimos matices-, asas, cuerpos y fondos, pone de relieve que estamos ante copias de Dressel 1, con morfologías documentadas próximas a todos los subtipos "clásicos" de la forma (A, B y C) establecidos por N. Lamboglia, estando la mayoría cercanas a las variantes A y B del prototipo itálico. No obstante, estas tipologías presentan particularidades propias, como queda evidente en el tamaño de los contenedores (de formato reducido) o en la morfología de los bordes y bases (Garcia Vargas e.p.). De esta forma, entendemos que dicha variabilidad con respecto a los modelos itálicos, solamente se puede entender de dos maneras. Bien como una consecuencia del fenómeno de imitación que discurre a la par que el de interpretación y experimentación formal, hasta la fijación del tipo propiamente sud-hispánico (García Vargas 2001: 62), o como una intención manifiesta de imitar de manera lo más verosímil posible los contenedores itálicos contemporáneos, y que pasaría por hacerlo con todas sus variantes. Este último aspecto se puede observar en las producciones tanto de la Bahía de Cádiz (Lagóstena Barrios y Bernal Casasola 2004: 79), como de las de Algeciras (Fernández Cacho 1995: 183).

Por todo lo dicho, entendemos que antes que considerar que las reproducciones provinciales de esta forma itálica se deben clasificar como prototipos antiguos de Dressel 12 o Dressel 12 iniciales (Étienne y Mayet 1995; Hesnard 1998: 293), es plenamente justificable individualizar y considerar las Dressel 1 sudhispanas, en este caso las del Guadalquivir, objeto de nuestro estudio, como un tipo con identidad propia, en la línea de lo que desde hace unos años se viene defendiendo (Fabião 2001; García Vargas 2001: 62; Bernal Casasola y Jimenez-Camino Álvarez 2004: 600-601; Almeida 2008: 66-76; García Vargas 2010; García Vargas e.p.),

Por lo tanto, no nos cabe ninguna duda de que existe toda una serie de imitaciones provinciales de Dressel 1 (cf. Almeida 2008: 60-61) que, por lo que hoy sabemos, pueden atribuirse a los alfares gaditanos, repartidos un poco por toda la bahía, a los de la bahía de Algeciras, como el de El Rinconcillo, a los de la costa malagueña (Cerro del Mar, Vélez-Málaga), y a los del valle del Guadalquivir, que son los que aquí nos interesan especialmente.

Los centros de producción del valle del Guadalquivir no se han localizado aún con claridad, pero la identificación en centros de consumo de ejemplares morfológicamente atribuibles al tipo Dressel 1 ha convertido esta producción en una realidad tangible. Consecuentemente, se asumió que un centro, o centros habrían 
fabricado contenedores que reprodujeron esta forma, destinada probablemente a transportar vino local. Tal premisa parece verse hoy confirmada por el hallazgo de un cuello de Dressel 1A similis de pasta local recogido en superficie en el alfar de Dehesa de Arrriba (Posadas, Córdoba), lo que permite identificar este área del entorno de Córdoba como una de las primeras en la producción de vinos de la región (García Vargas y Bernal Casasola 2008: 672, García Vargas e.p.).

Los primeros indicios de la existencia de Dressel 1 del Guadalquivir surgen con la constatación de ejemplares con las pastas "arenosas" características de las Haltern 70 y las Dressel 20 (Fabião 2001: 667), en la publicación preliminar de los materiales republicanos de Mesas do Castelinho, en Almodôvar (Fabião y Guerra 1994: 280, fig. $7, n^{\circ} 3$ ). Sin embargo, considerando su grado de fragmentación, se hacía indispensable identificar algo más que fragmentos de boca para que se pudiese confirmar que se trataba de una "réplica" del contenedor itálico (Fabião 1998a: 179). Mientras no surgía esa confirmación categórica, fueron reconocidos diversos especímenes con petrografías atribuibles al valle del Guadalquivir, particularmente en la región oriental hispánica incluida en la provincia Citerior Tarraconense (Molina Vidal 1997)².

Sin embargo, habría que esperar a la publicación de nueve ejemplares fragmentarios y uno completo del poblado minero de La Loba, en Fuenteovejuna (Córdoba) (Benquet y Olmer 2002), para llegar a que las Dressel 1 del Guadalquivir fueran plenamente reconocidas como tipo propio. A pesar de que en la publicación de L. Benquet y F. Olmer se señala que un grupo de pastas de estas producciones podría corresponder a ejemplares del entorno de la bahía de Cádiz, lo cierto es que la fotografía publicada de la misma (fig.151.3) nos parece igualmente compatible con el valle del Guadalquivir. Estas producciones de Dressel 1 surgen en número porcentualmente significativo, asociadas a una gran cantidad de importaciones itálicas de contextos fechados entre el final del siglo II a.C. y el primer tercio del siglo I a.C. (110-90 a.C.) (Benquet y Olmer, 2002: 323-328). Las Dressel 1 de La Loba pueden considerarse cercanas formalmente a los subtipos A y B. El único ejemplar conservado por completo (Fig. 3) resulta próximo a la variante $\mathrm{A}$, pero tanto el pequeño tamaño del ánfora, no

2. La información disponible se encuentra en el apartado de caracterización de las producciones anfóricas, en el cual el autor apunta la existencia de Dressel 1B (un 1,8\%) y 1C (un 1,6\%) con pastas de su Grupo 9 (Molina Vidal 1997: 138) -es decir, el grupo petrográfico del Guadalquivir, común a las Clase 67, Haltern 70, Dressel 25 y Dressel 20- no volviendo a realizar otro tipo de referencia gráfica o textual concreta a esta producción. superior a los $85 \mathrm{~cm}$. de altura total, como la forma del cuerpo y la escasa altura del pivote la dotan de un aspecto singular.

Aún en la cuenca del Guadalquivir se identificaron más ejemplares en la ciudad de Munigua (Sevilla) (Fabião 2006) ${ }^{3}$, pero en contextos de recepción poco claros. Cabe destacar igualmente que además de los ejemplares de producción regional, ambos yacimientos presentaban también un porcentaje significativo de Dressel 1 producidas en la bahía de Cádiz y en otras áreas indeterminadas de la costa Bética.

Actualmente, el inventario de piezas con origen en el Guadalquivir ha aumentado en ámbito regional y supra-regional, ganando su consumo una nueva dimensión con la identificación de fragmentos en diversos contextos de la costa atlántica y en su área de penetración más inmediata, en contextos algo posteriores, de la segunda mitad del siglo I a.C., como son Santarém (Almeida 2008), Mesas do Castelinho (Parreira 2009) y Faro (Viegas 2011).

La investigación en los centros de consumo hizo sentir en la zona de producción un cierto interés por la forma, al contarse aquí con contextos cronológicamente más definidos y esclarecedores. De esta manera, en la misma Hispalis, concretamente de la excavación de 2010 en el Patio de Banderas del Alcázar de Sevilla, se recuperaron varios individuos, estando los más antiguos fechados en la primera mitad del siglo I a.C. ${ }^{5}, \mathrm{y}$

3. Agradecemos al Prof. Carlos Fabião los datos, algunos publicados parcialmente, otros en fase de conclusión, referentes al estudio de las importaciones anfóricas de Munigua.

4. Poco más se puede añadir aparte de un reducido número de puntos en el mapa, que a pesar de todo resulta bastante significativo, dado el desconocimiento generalizado que se posee de su distribución (Almeida 2008: 64), destacando: Cerro do Cavaco (Tavira), con un conjunto anfórico que se puede encuadrar en la primera mitad del siglo I a.C.; Faro (Viegas 2011: 205 y 246; Est. 29, nº 419 y $420)$, aparentemente en contextos del segundo y tercer tercio del siglo I a.C.; Mesas do Castelinho (Almodôvar), con un conjunto numeroso, con sólo algunos en contextos atribuibles al siglo I a.C. (Fabião y Guerra 1994: 279-280; Fabião 1998; Fabião 2001), y siendo la mayoría de momentos iniciales del principado (Parreira 2009: 56; Est. XII y XIII); Lisboa, con un fragmento descontextualizado (Pimenta 2005); Scallabis (Santarém), varios fragmentos, la mayoría procedentes de estratos de construcción o remodelación del último cuarto del siglo I a.C. y del primero del I d.C. (Almeida 2008: 68-69).

5. De la Fase I del Patio de Banderas del Alcázar de Sevilla se conocen dos ejemplares de borde similares a los de Dressel 1A. Ambos pueden fecharse en torno al primer cuarto del siglo I a.C., en función de su contexto estratigráfico y cerámico, que incluye ánforas Pellicer D, Dressel 1 itálicas, Lamboglia 2, ánforas púnico-gaditanas, de la Tripolitania y brindisinas, alguna con sello $A P O L L O N[i]$. Es por tanto un contexto muy próximo cronológicamente al de la mina de La Loba (Bernal Casasola y otros e.p), como indica la presencia en ambos del mismo sello brindisino. 


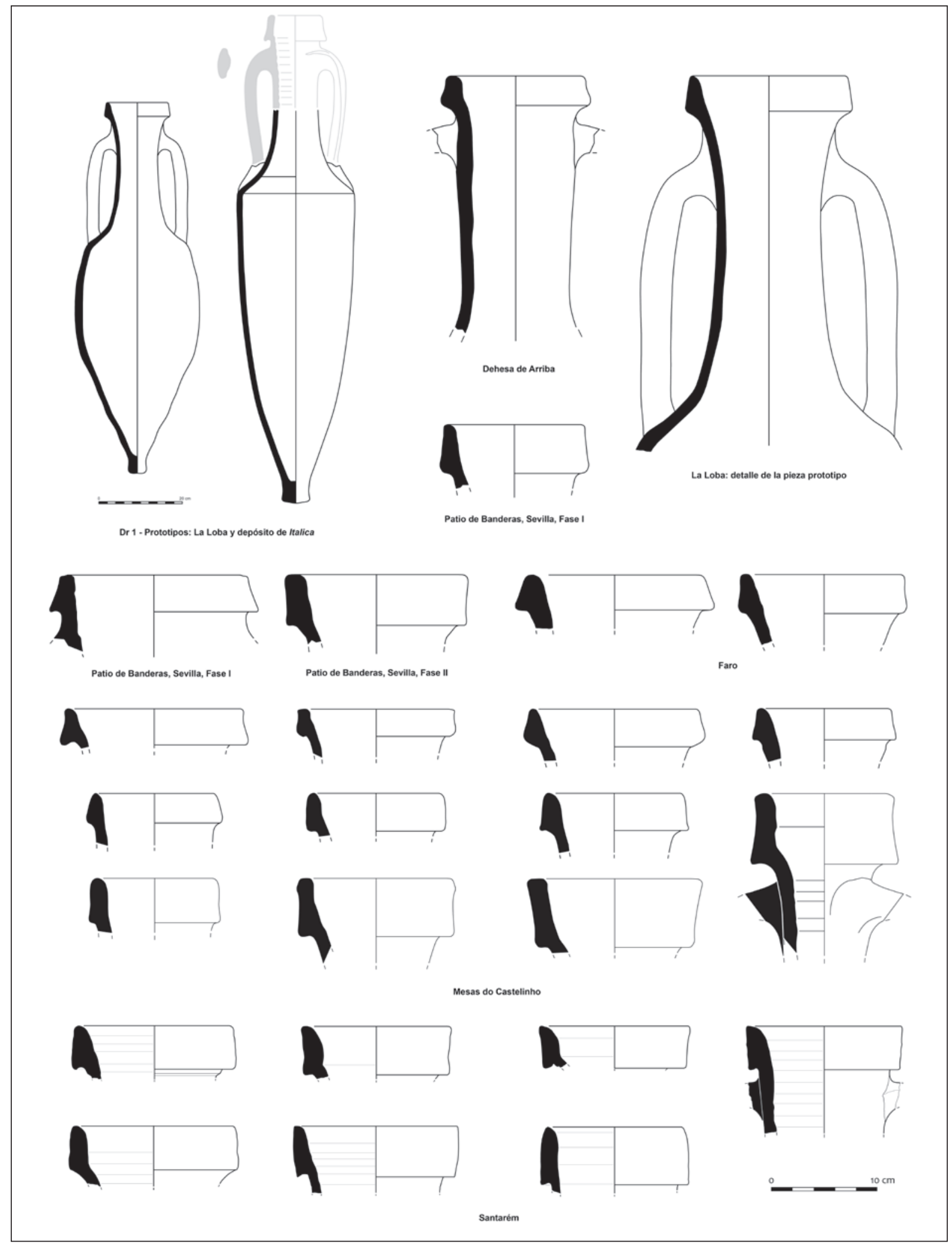

Figura 3. Dressel 1. Prototipos y fragmentos producidos en el Guadalquivir. 
los más recientes en el tercer cuarto de la centuria, todos ellos en contextos inmediatamente pré-augusteos ${ }^{6}$. Igualmente, en Itálica (Santiponce, Sevilla) se recuperó el cuerpo de una Dressel 1C local, fechada a mediados del siglo I a.C. 7 (García Vargas e.p.: 5).

Los datos ahora sintetizados revelan un cuadro de producción y difusión enmarcado entre el primer cuarto del siglo I a.C. y probablemente los años finales del mismo siglo, en el cual se realiza sobre todo una comercialización a nivel regional o supra-regional, puesto que se desconocen de momento ejemplares fuera del ámbito geográfico peninsular. No obstante, creemos que la producción de este tipo muy probablemente sería más numerosa de lo que se puede apreciar de la cantidad de hallazgos actuales, y que seguramente tenderá a aumentar al realizarse un rastreo exhaustivo, acompañado de una correcta caracterización petrográfica ${ }^{8}$.

\section{Mañá C2b (T.7.4.3.3) (fig. 4)}

El tipo tradicionalmente conocido como Mañá $\mathrm{C} 2 \mathrm{~b}$ es una de las más conocidas y difundidas producciones tardorrepublicanas de la Ulterior, tanto a nivel de producción como de exportación. El mapa de su distribución (Ramón Torres 1994: 635, mapa 83) revela que se trata de un contenedor ampliamente difundido y extensible a toda la mitad occidental del Mediterráneo, particularmente en zonas costeras y de penetración fluvial inmediata asociadas a ellas (Lagóstena Barrios 1996b : 145), con zonas de mayor concentración como pueden ser los yacimientos de la actual Andalucía, del sureste peninsular (Molina Vidal 1997) y de la fachada atlántica, tal como certifican los hallazgos del actual territorio portugués (Fabião 1989; Arruda y Almeida 1998; Almeida y Arruda 2005; Pimenta 2005) y de Galicia

6. Se trata de un borde subrectangular asimilable a la Dressel 1B, con pasta marrón similar a la de las Haltern 70 y Dressel 20 clásicas, que procede de la UE 1818 ( $\mathrm{n}^{\circ}$ inv. 1581) de la Fase II del Patio de Banderas, fechada hacia 50-25 a.C.

7. Este ejemplar que se puede adscribir a la variante $C$ de la Dressel 1 apareció en un depósito anfórico próximo al área portuaria (García Fernández 2004), asociado a ánforas Dressel 1b itálicas y locales, Ovoide 1, Ovoide 2, Ovoide 6 y Mañá C2b (o T. 7.4.3.3), una asociación que consideramos típica del periodo en torno a mediados del siglo I a.C. (García Vargas e.p.).

8. Creemos que muchos fragmentos con origen en el Guadalquivir se encuentran "camuflados" bajo la designación genérica de "Dressel 1 hispánicas" o "Dressel 1 béticas", designaciones que son escasamente útiles dada la comprobada diversidad de áreas productoras que ofrece la Provincia.
(Naveiro López 1991; González-Ruibal 2004; González-Ruibal y otros 2007).

La primacía del entorno gaditano en la producción y exportación de este tipo desde el último cuarto del siglo I a.C., está fuera de cualquier duda (Lagóstena Barrios y Bernal Casasola 2004), a pesar de haberse documentado también su producción en la costa de Málaga en un momento coetáneo, particularmente en Cerro del Mar (Arteaga Matute 1985: 213; Ferrer Albelda y García Vargas 2001: 550-551). De ese práctico monopolio dan testimonio la gran mayoría de los ejemplares identificados en los contextos de la fachada atlántica y fechables en momentos tardíos de la República (Arruda y Almeida 1998; Pimenta 2005). No obstante, en el caso de unos pocos fragmentos de Scallabis (Santarém) se puso sobre la mesa, a modo de hipótesis de trabajo, la posibilidad de que tuviesen un origen en algún alfar del Guadalquivir (Arruda y Almeida 1998: 215).

Esta coyuntura productiva y comercial ganó recientemente una nueva dimensión con la identificación y recopilación de varios ejemplares con petrografías atribuibles al Valle del Guadalquivir (Almeida 2008: con inventario de sitios). Las características de las pastas identificadas parecen apuntar hacia alfares ubicados en el curso bajo del rio, o afluentes en el mismo paralelo, con grandes probabilidades de que se localicen también en el área de las Marismas. Al incluirse el valle del Guadalquivir en el mapa de la producción de este tipo, se sumaron otras cuestiones que se relacionan con el significado, el ámbito, la cronología, el volumen de su producción y exportación, así como los que conciernen al producto o serie de productos envasados. Para algunas de estas cuestiones existen respuestas más o menos concluyentes, mientras que para otras únicamente indicios o líneas de trabajo.

En lo que concierne el posible significado y ámbito de su producción, entendemos que la manufactura de este tipo se debe de integrar, tal como el propio título de este apartado indica, en el proceso de reproducción de contenedores de éxito, en este caso supra-regional. Así mismo, este modelo anfórico, con una buena adaptabilidad ya probada en el mundo cartaginés, y que fue posteriormente elegido y asimilado por la industria salazonera gaditana para exportar un producto conocido y producido desde hacía tiempo en la región (Ramón Torres 2004: 83) comercializándose hacia Occidente a la par que los productos tirrénicos, parece haber sido de igual modo asimilado y reproducido en algunos alfares de la cuenca inferior del Betis. De ese modo, la Maña C2b del Guadalquivir representa la reproducción de más "una forma de éxito internacional", tal vez la más exitosa tras las de los tipos vinarios itálicos. 


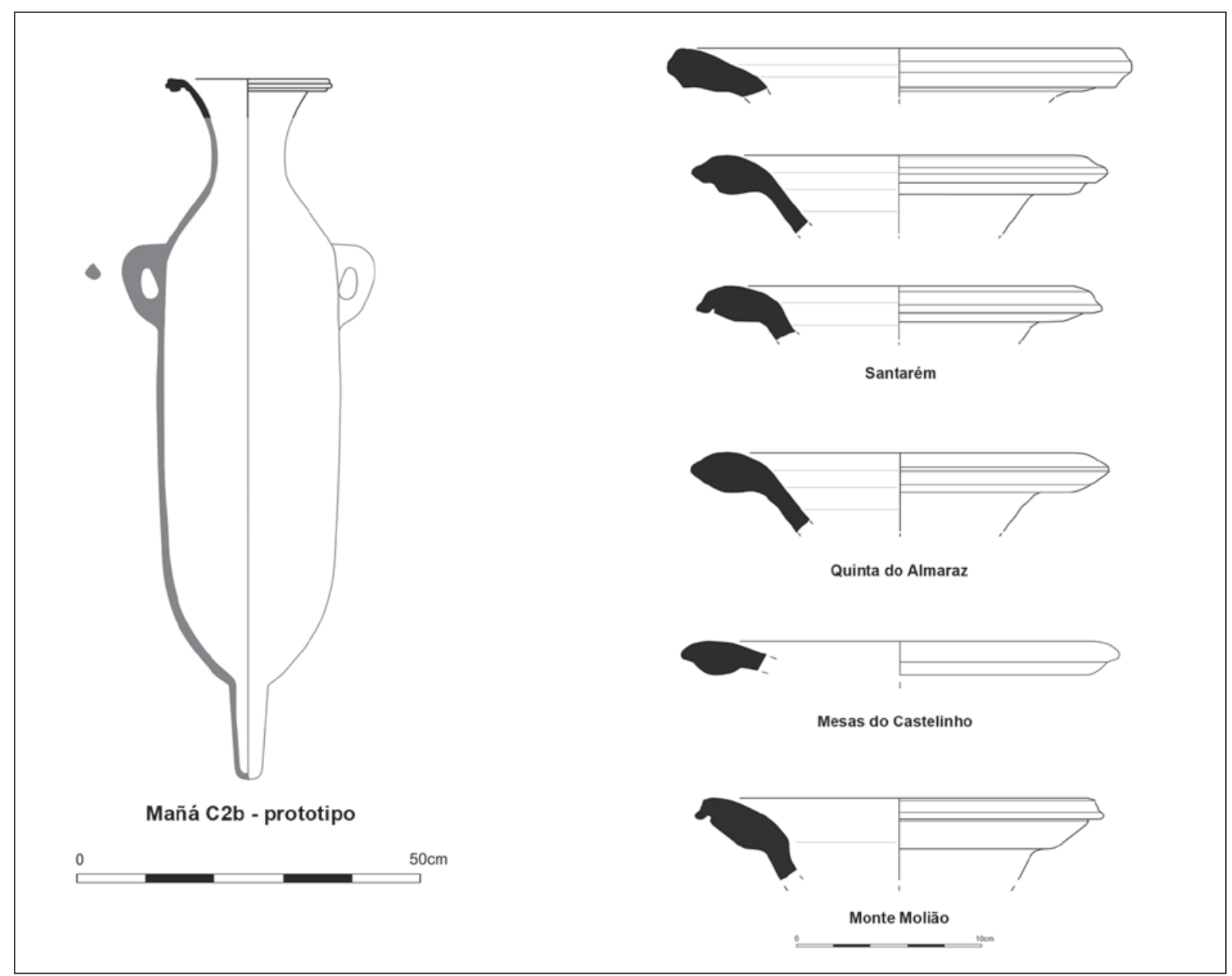

Figura 4. Mañá C2b. Prototipo y fragmentos con producción en el Guadalquivir.

Haciendo prevalecer el primado de la morfología y de la geografía, esta forma puede estar relacionada con los primeros intentos de comercialización de productos derivados del pescado del interior de la Provincia, en este caso con origen fluvial o marismeño, representando el estadio precedente de los posteriores tipos incluidos en el grupo de las Dressel 7-11 de época imperial producidas en el mismo ámbito, de las que ya disponemos de numerosos testimonios de producción en el bajo Guadalquivir -especialmente en Orippo (Dos Hermanas) y posiblemente también en Cerro de Overo y Rancho Centeno (Carreras Monfort 2001)- pero también de consumo (Morais 2005; Almeida 2008). No obstante, si valoramos únicamente el aspecto formal, también son posibles otros contenidos. En este sentido hay que recordar el titulus del ejemplar del Museo de Jerez de La Frontera que refiere ¿vin $[u m ?] / d u(\ldots)$ (García Vargas 1998: 203 y lám. 3.1), o los de Lixus, que contenían pepitas de uva o aún mejillones en vinagreta (Aranegui Gascó y otros 2004: 373). Los distintos contenidos alertan de la posibilidad de un carácter bivalente, o polivalente, donde, a pesar de todo, lo más probable es que hayan predominado los contenidos de salazones sobre los demás.

En lo relativo a la cronología y al volumen aparente de su distribución, al contrario de la región gaditana, donde la producción arranca aún dentro del siglo II a.C. (Sáez Romero 2008: 571-572), la del Guadalquivir parece desarrollarse en un momento avanzado, cercano a mediados del siglo I a.C., o ya en la segunda mitad, tal como se puede deducir de los contextos de consumo atlánticos (Almeida 2008; Almeida 2010). Sin embargo, el novedoso hallazgo de un ejemplar con pasta de las Marismas en Monte Molião (Lagos, Portugal), permite confirmar su producción/exportación ya en la primera mitad del siglo I a.C. (Arruda y Pereira 2010: 706-707). 
La localización de los conjuntos conocidos actualmente, limitada prácticamente a yacimientos del actual territorio portugués ${ }^{9}$, la mayoría relacionados de alguna forma con la presencia militar, no deja lugar a dudas en cuanto a una comercialización exclusivamente occidental para las Maña C2b manufacturadas en el Guadalquivir, aunque desconocemos el volumen de su aportación dentro de la producción local y consecuentemente del destinado al comercio supra-regional. Sin embargo, los datos que ahora se barajan parecen justificar que sigamos considerándola como una producción minoritaria en su área productiva (Almeida 2008: 58-59).

\subsubsection{Segundo grupo. Contenedores de vida} breve con escaso éxito en los mercados.

Dentro del segundo grupo de ánforas hemos incluido aquellas tipologías que por razones para las cuales en principio no tenemos respuesta, sólo fueron producidas durante un breve periodo, no llegando a tener el éxito necesario para pervivir o evolucionar hacia nuevos modelos. Podemos decir que son tipos que se quedan por el camino, que en cierta medida pueden ser considerados como experimentos " que no llegan a consolidarse y después de no más de dos o tres decenios desaparecen", bien sea debido a su rechazo o en los mercados de consumo o por su descarte por parte de los alfareros béticos.

Dentro de esta categoría entrarían varios de los "tipos minoritários" que han sido recientemente definidos y caracterizados a raíz de ejemplares documentados en la fachada atlántica, y de los cuales apenas se tiene constancia en escasos yacimientos, casi exclusivamente peninsulares (Almeida 2008; Almeida 2010). Nos estamos refiriendo principalmente a aquellos clasificados

9. De momento, su presencia se encuentra documentada en: Cerro do Cavaco (Tavira), un conjunto recogido en superficie y mayoritariamente encuadrable en la primera mitad del siglo I a.C. (Almeida 2008); poblado de Mesas do Castelinho (Parreira 2009: 50), en contextos del siglo I a.C. anteriores a la implantación del principado; Faro en contextos de la segunda mitad del I a.C. (Viegas 2011: 197) Monte Molião (Lagos), en el interior de un espacio dedicado a actividades metalúrgicas domésticas, fechado, como se ha indicado, en la primera mitad del siglo I a.C. (Arruda e Pereira 2010: 706-707); Quinta do Almaraz (Almada), también de superficie un conjunto con clara connotación tardorrepublicana (Barros y Henriques 2002); Sca1llabis (Santarém), en contextos atribuibles a momentos finales de la República e inicios del Imperio (Almeida 2008: 57-59). En la supuesta área productora sólo conocemos un fragmento descontextualizado de boca con pasta del Guadalquivir documentado recientemente en un nivel islámico (siglo XI) del Patio de Banderas del Real Alcázar de Sevilla. como Ovoide 2 y Ovoide 3, y otros tipos ovoides sin apenas difusión o con difusión limitada en el tiempo, como las Ovoides 8 y 9, el tipo 10 y ciertas formas singulares, documentadas por ejemplo en Valeria (González Cesteros e.p.), que carecen de mejor caracterización y definición, si bien no pueden considerarse como envases de tipología ovoide.

\section{Ovoide 2 (figs. 5-6)}

Una de las recientes propuestas de trabajo respecto a los contenedores minoritarios procedentes del Guadalquivir, con base en el conjunto estudiado en Scallabis, fue la definición del tipo Ovoide 2. A pesar de que no existe una evidencia material manifiestamente abundante, las características propias y singulares que presentaban los fragmentos de Santarém -que no solo no se encuadraban en ninguno de los tipos producidos en el ámbito regional, sino que tampoco encajaban en ninguna de las formas de referencia- fueron consideradas como suficientemente relevantes para su individualización como tipo independiente. Se separaron así de las ánforas ovoides "clásicas" del Guadalquivir (como son las Ovoide 1 (LC67) y las Ovoide 4 ('Haltern 70 unusually small variant") y constituyeron una nueva forma presumiblemente ovoide denominada tipo Ovoide 2 y fechada en la segunda mitad del siglo I a.C. (Almeida 2008: 84ss).

Los fragmentos de borde que se definieron como característicos de este tipo (Fig. 6) presentan un perfil simple y macizo, de sección tendente a subrectangular, que arranca directamente en la continuación de la pared del cuello, con una altura entre los 2 y $\operatorname{los} 3 \mathrm{~cm}$, y definen bocas con diámetros comprendidos entre los 13,5 y $\operatorname{los} 15,5 \mathrm{~cm}$. En su cara externa el labio se presenta bastante vertical, y en la interna puede presentarse tanto recto como ligeramente convexo. Termina de forma abrupta y bastante marcada, asumiendo al exterior el aspecto de una banda recta. Al conjunto de las características de estas bocas entendemos se asocia un cuello de reducida longitud y de perfil bitroncocónico, que conecta suavemente con el cuerpo, y del cual parten asas de perfil semicircular e igualmente cortas.

Teniendo por base estas características, se pueden asimilar fácilmente los fragmentos del tipo Ovoide 2 a las producciones brindisinas o a otros tipos ovoides del siglo I a.C. de procedencia indeterminada como lo fueron en su día las problemáticas formas 24 o 26 de la tabla de Dressel (Zevi 1966: 223; Beltrán Lloris 1970), hoy bien caracterizadas y que se atribuyen a producciones 


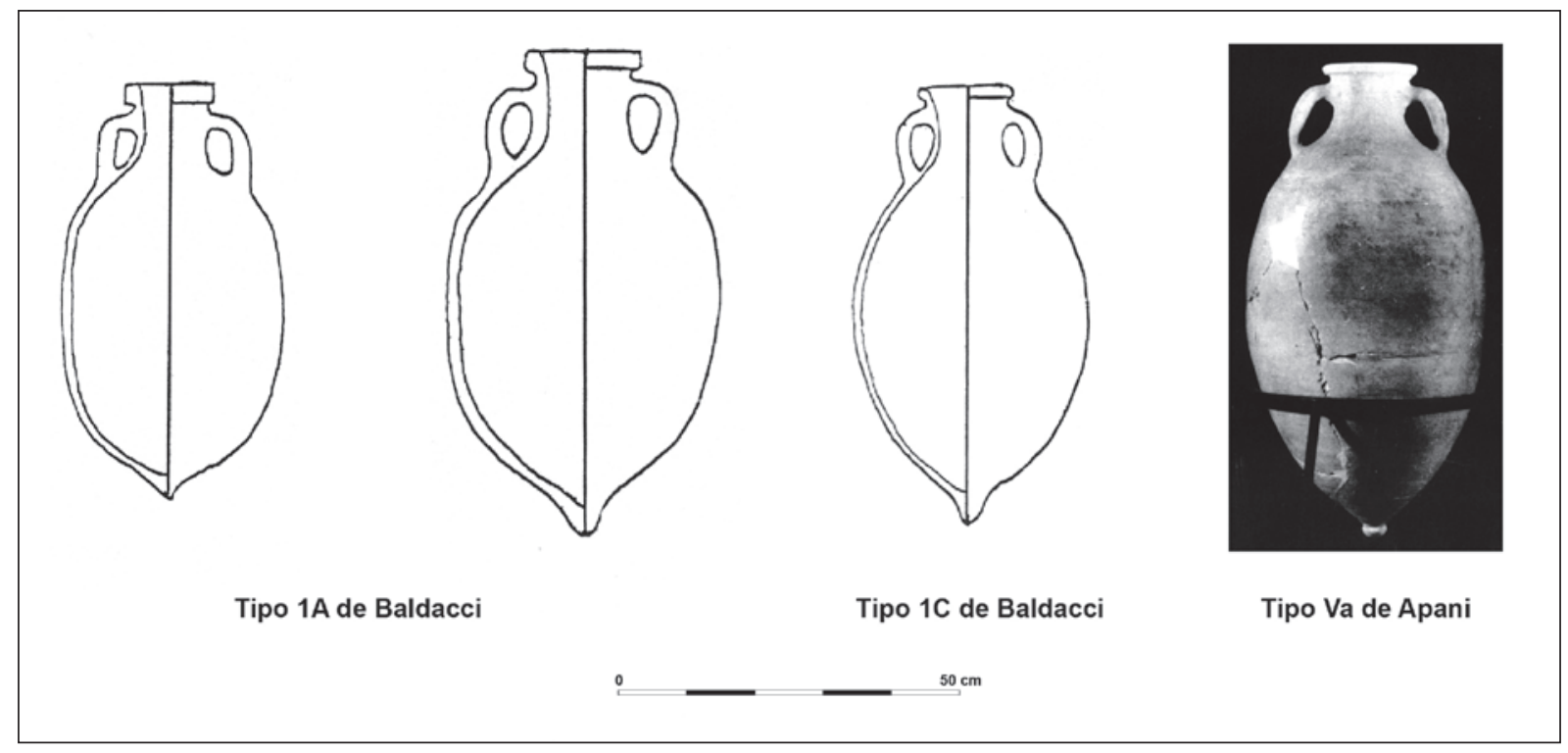

Figura 5. Probables prototipos del tipo Ovoide 2 del Guadalquivir.

especificas del Mediterráneo oriental y central, respectivamente. Clasificarlas como ánforas ovoides en general, es la solución más cómoda pero también la más peligrosa, puesto que inscribir este "nuevo" tipo del Guadalquivir en la gran familia de las designadas "ánforas ovoides" indeterminadas poco contribuye a su correcta definición y encuadre tipológico. Por otra parte, intentando establecer conexiones más concretas y cercanas, nos parece que la forma en cuestión no sólo no cabe dentro de la variabilidad formal establecida para otros tipos ovoides del Guadalquivir, como pueden ser las Ovoide 4, Ovoide 6 u Ovoide 5, sino que es importante procurar no confundirlas con las mismas, incluso cuando tan sólo se tienen evidencias fragmentarias. Estas ánforas difieren igualmente de las "ovoides gaditanas", tanto por su procedencia geográfica como por la morfología de la boca y del cuello, únicos elementos que de momento se pueden analizar con alguna objetividad. Algunas de las ovoides gaditanas presentan, es cierto, bordes de labio corto con tendencia rectangular y sin moldura -ejemplares del Museo de Jerez de la Frontera, de La Caleta (según García Vargas 1998: 74) y del Convento de las Concepcionistas de Vejer de la Frontera- pero, aun así, poseen bocas de una apertura más amplia y más exvasada, apartándose más del cuello del cual casi constituyen una prolongación (García Vargas 1998: 74; García Vargas 2001).

Como consecuencia de todo lo anterior, y pese a los riesgos que conlleva la individualización del tipo Ovoide 2 (ya algo más que provisional) consideramos que agrupar bajo la simple designación de "tipo ovoide indeterminado" todos los ejemplares que comparten las características morfológicas indicadas supra, puede complicar más que aclarar el panorama (Almeida 2008: 83), pues es sabido que bajo esta genérica designación se pueden agrupar formas no sólo de distinta cronología, sino también de distinta procedencia ${ }^{10}$.

El origen de la forma Ovoide 2, cuya individuación seguimos proponiendo, en la línea de otras publicaciones (Almeida 2008, 2010, García Vargas e. p. González Cestros e. p.), parece radicar una vez más en parámetros formales del repertorio suditálico y medioadriático, por lo que se puede admitir una producción "inspirada" o tipológicamente próxima a las mismas. Es el caso de las formas de la región apula incluidas en los tipos $1 \mathrm{~A}\left(\mathrm{n}^{\circ} \mathrm{s}\right.$ 1 y 2) y 1C ( $\left.n^{\circ} 3\right)$ de Baldacci (Baldacci 1972: 25-27 y Tav.1, ns 3, 4 y 10), y del Grupo Va de las actualmente designadas producciones de Apani (nos 4 y 5) (Palazzo

10. Se puede indicar que un escenario con estas características es el que actualmente existe para gran parte de los naufragios fechados en la primera mitad del siglo I a.C. en el Mediterráneo. En conjuntos de enorme relevancia e importancia para la comprensión del tráfico marítimo como pueden ser los pecios de Planier C, Punta Scalleta, Gianuttri, Melilla, Cap Sicié, Planier 5, Grand-Conglué 3 y Titán, en los cuales existe gran cantidad y enorme variabilidad de morfologías ovoides. Desgraciadamente, el grado de desconocimiento que tenemos de las distintas regiones productoras existentes en el Mediterráneo antiguo, y de los tipos anfóricos manufacturados en ellas, no nos permite extraer datos más precisos, persistiendo la imprecisa denominación "ovoide" para referirnos a muchos de esos contenedores. 
1989: 548-549, fig.3, 17-18). De la región del Lacio hay menos ejemplos, aunque ha de tenerse en cuenta el material de algunas de sus alfarerías, concretamente el de Astura (Hesnard y otros 1989: 24)(fig. 5)

Hasta fechas cercanas sólo se conocían los ejemplares de Santarém y otra posible pieza procedente de Itálica y depositada en el Museo de Sevilla ${ }^{11}$, pero ahora contamos con más ejemplares que pueden ser clasificados como Ovoide 2. Tal es el caso de algunos fragmentos de Castro Marim, clasificados como Haltern 70/ Ovoide 4 y Dressel 20A ( incluye Ovoide 6 y Oberaden 83. Berni, 1998) (Viegas 2011: 493-496; Estampa 104. 1321; Estampa 106.1355; Estampa 109.1385), o igualmente del de las piezas de Lixus, del horizonte Mauritano Medio, también clasificadas como Dressel 20A (Bonet Rosado y otros 2005: 122, fig. 16.6 y 7). Más interesante es el caso de un individuo de borde con cuello y arranque del asa de la ciudad de Valeria (Cuenca), en el interior de la Península, para la cual ya se plantearon algunas dudas y reservas (González Cesteros e.p.). El borde y el cuello corto bitroncocónico se ajustan plenamente al tipo Ovoide 2, pero la fractura del arranque del asa parece preludiar un asa hecha de forma tosca con dos bastones o rulos, a la manera característica de las posteriores Dressel 2-4. A pesar de ello, nos resistimos a caracterizar esta pieza como una Dressel 2-4, ya que formalmente el labio y el cuello son completamente distintos del tipo itálico, que además es posterior cronológicamente. Además, en el caso de esta pieza, tampoco habría lugar a que el asa tuviera un perfil semejante a las de las Dressel 2-4, sino más bien ha de tratarse de un asa corta, a semejanza de otros tipos ovoides. Por este motivo, pensamos que o bien se trata de un asa bífida corta o, como alternativa, puede representar un episodio de adaptabilidad mezclada con "savoir faire", es decir, puede que eventualmente represente un estadio inicial o una variante de asa de cinta acanalada en el dorso, morfología que es típica del Guadalquivir ${ }^{12}$.

11. El posible ejemplar de Itálica, que no obstante, presenta algunas características peculiares desde el punto de vista formal, se integra en un conjunto extremadamente interesante compuesto por Dressel 1 de producción itálica y regional, Maña C2b, Ovoide 6 y Ovoide 1. Hemos tenido la oportunidad de ver este conjunto en el Museo Arqueológico de Sevilla, y de estudiar algunas de las piezas (García Vargas e.p.).

12. Si no se tiene la costumbre de fabricar un asa con sección ovalada y profunda acanaladura central, se puede conseguir un efecto similar con la simple unión de dos bastones circulares, lo que resulta típico de modelos orientales y suditálicos, y, por ejemplo, alisar la parte inferior del asa. Con ello, se consigue obtener un dorso con aspecto cercano al de las "típicas" asas del Guadalquivir. Se trata de una solución técnica simple ante la carencia de un "saber hacer"
Los fragmentos actualmente documentados del tipo Ovoide 2 con cronologías fiables siempre se encuadran en marcos cronológicos ceñidos a la segunda mitad del siglo I a.C. Pese al descubrimiento de los nuevos fragmentos que se presentan aquí, que apuntalan un tanto la definición del tipo, aún no se encuentran absolutamente disipadas las dudas metodológicas y tipológicas referidas supra, acerca de la pertinencia de la formulación del tipo Ovoide 2 (Almeida 2008: 83-85), pero es quizás un referente más a la hora de discutir la existencia de producciones singulares y minoritarias cuya correcta definición se nos sigue escapando en el estado actual de la investigación (García Vargas e.p.) (fig. 6).

\section{Ovoide 3 (fig. 7)}

Al igual que el tipo anterior, también la forma Ovoide 3 fue caracterizada y definida a partir de ejemplares de Santarém, representando otro caso de difícil clasificación debido a lo fragmentario de la evidencia y a la práctica ausencia de paralelos en las tipologías de referencia. Las reservas expresadas al respecto desu individualización continúan aún siendo hoy totalmente validas, pues hay que tener presente que el tipo se encuentra justificado en la singularidad de sus detalles morfológicos, pero la definición del tipo debe ser tomada con prudencia y considerarse abierta la posible asimilación a otros tipos, aunque entendemos que ello es poco probable (Almeida 2008: 86-87).

Los fragmentos identificados en Santarém se caracterizan formalmente como bordes que definen bocas con diámetros comprendidos entre los 16 y los $18 \mathrm{~cm}$, con labios macizos de perfil moldurado de aproximadamente $3 \mathrm{~cm}$ de altura y sección de tendencia subrectangular. La parte externa del labio presenta una concavidad acentuada en su área medial, asumiendo una forma en banda recta con surco, que define a veces un apéndice basal más o menos proyectado (García Vargas e.p.). Este apéndice recuerda en ocasiones el aspecto de una doble moldura, pero no puede clasificarse como tal,

determinado. Un fenómeno similar pero a la inversa es el que podrá existir en otros momentos, a raíz de la producción de las Dressel 2-4 del Guadalquivir, en las cuales se puede observar frecuentemente que las asas son "falsas bífidas". En este caso, en un asa larga con sección longitudinal se practica un incisión profunda en ambos lados, acción bastante más sencilla, pero que a efectos prácticos permite simular el aspecto del asa bífida característica de este tipo de contenedor vinario. Sobre este tipo de ánforas, las Dressel 2-4, debe decirse que, de momento, no están constatadas de modo seguro producciones del Guadalquivir hasta época imperial (García Vargas 2004 a y b; Almeida 2008) 


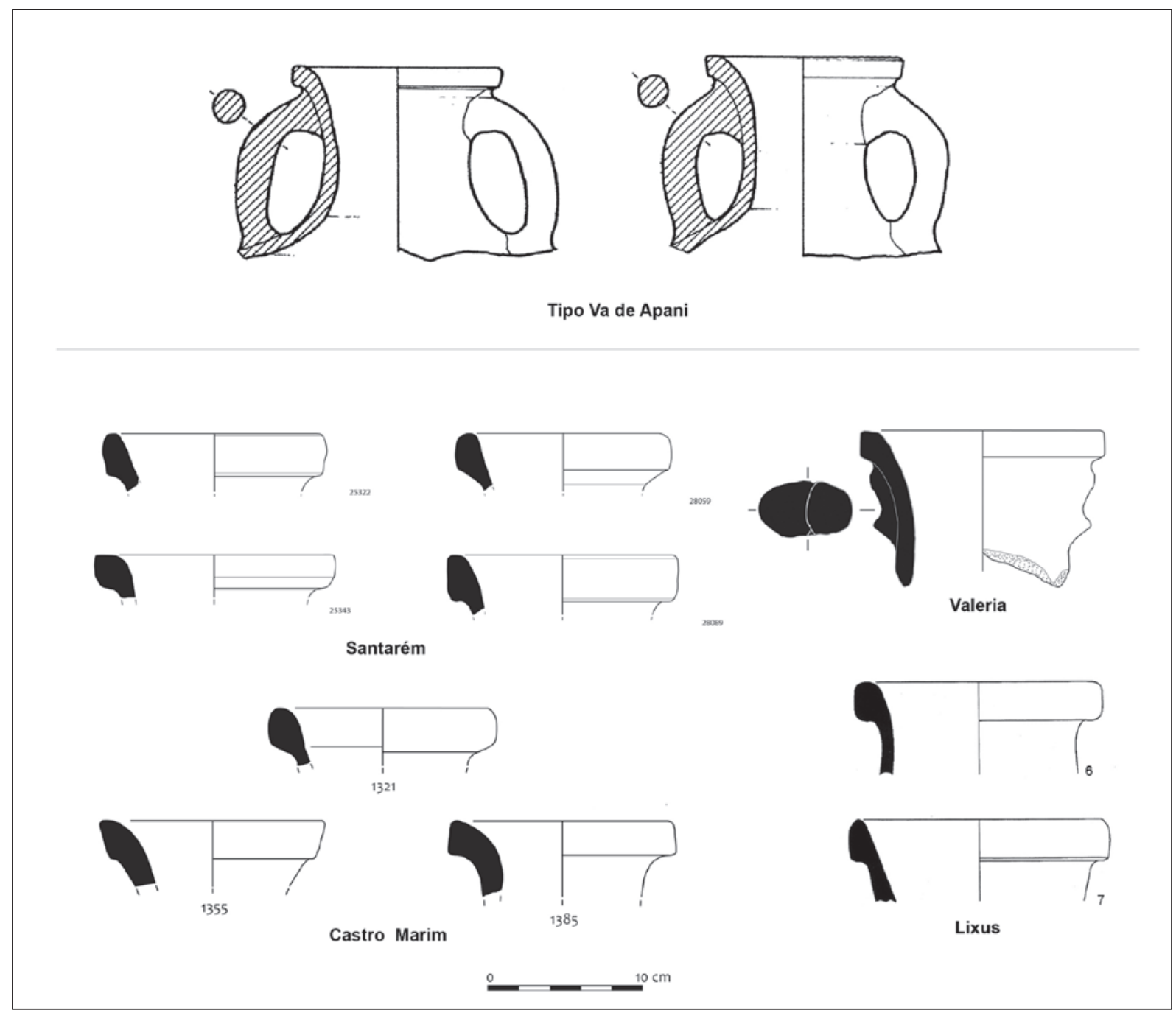

Figura 6. Formas comparativas sur-itálicas (arriba) y fragmentos atribuibles al tipo Ovoide 2 (abajo).

ya que no se trata de dos molduras claramente diferenciadas. El labio termina de forma bastante abrupta, separándose claramente del cuello. A las bocas con este conjunto de características se asocia habitualmente un cuello corto y bitroncocónico del que parten las asas, aparentemente cortas y en forma de cuarto de círculo, macizas y con una sección subcircular. Teniendo por base todos estos elementos, se planteó un contenedor de tendencia ovoide (Almeida 2008: 87), algo que parece confirmarse (infra).

Afortunadamente, y al contrario del tipo Ovoide 2 presentado con anterioridad, en este caso sí que contamos con algún ejemplar completo para plantear una morfología general. De este modo, pensamos que algunas de las ánforas transportadas a bordo del pecio
Grand-Conglué 3, que fueron clasificadas originalmente como "Dressel 10" (entiéndase tipo ovoide gaditano) (Liou 2001: 1102, lám. J, no 5), hecho a nuestro entender bastante comprensible dados algunos rasgos similares entre ambos tipos, son en realidad Ovoides 3. Parte de los detalles morfológicos descritos, particularmente el labio "pseudo-moldurado", recuerda también algunos rasgos de las ánforas de fondo plano Dressel 28, en concreto un ejemplar del naufragio de Lavezzi 1 (Liou 1990; Liou 2001: 1077, Lám.II, 4), pero la forma más maciza del borde de nuestro tipo se aleja de éstas. Así mismo, al diámetro superior y la particular forma de las asas, observable a nivel de los fragmentos, se suma un cuerpo y pivote que se presentan afines a las producciones ovoides provinciales, sobre 


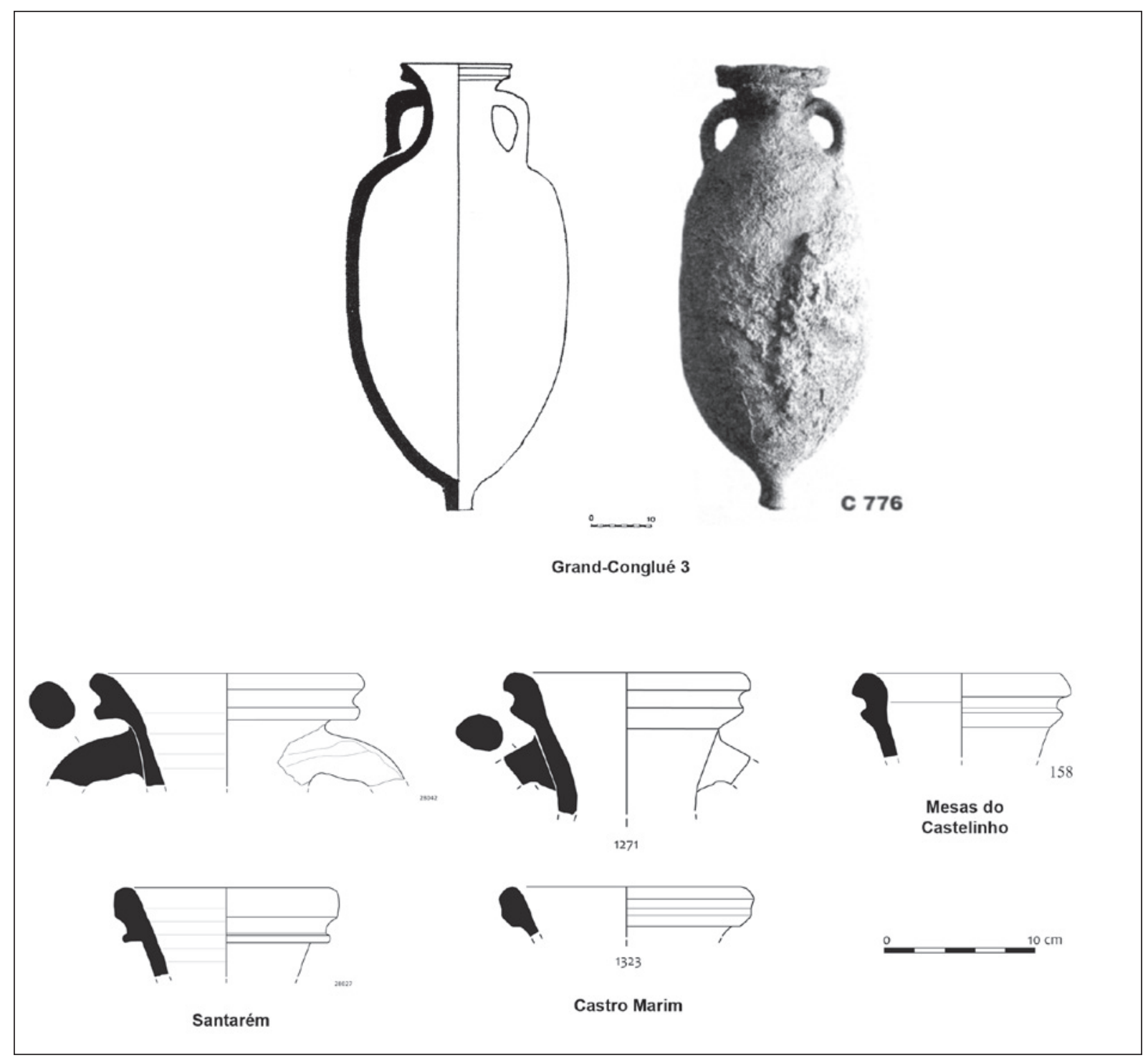

Figura 7. Tipo Ovoide 3 completo (arriba) y fragmentos atribuibles al tipo Ovoide 3 (abajo).

todo de producción del Guadalquivir, destacando la innegable proximidad morfológica que guarda con el tipo Ovoide 1, lo que en ocasiones podría llevar a equívocos entre ambos tipos.

Actualmente, la identificación de nuevos ejemplares, algunos conjugando las distintas características definidas para el tipo, mientras que otros sólo con algunos rasgos que nos llevan a atribuirlos al tipo con algunas reservas, contribuyen a la consolidación de la propuesta de una forma independiente para estos ejemplares, aunque serán necesarias más piezas completas o ejemplares fragmentarios de mayores dimensiones a los que tenemos hasta ahora, para confirmar la correcta constitución de este grupo y su homogeneidad o variabilidad interna.

Los fragmentos novedosos que entendemos como integrantes del tipo Ovoide 3 proceden de nuevo de sitios de la fachada atlántica peninsular, concretamente de la meridional: Castro Marim (Viegas 2011: 486ss) y Mesas do Castelinho (Parreira 2009: Est. XVI.158). Se trata en ambos casos de ejemplares que han sido clasificados como Ovoide 1 (Clase 67/LC. 67), aunque nos parece que se deben separar de esta forma (cf. fig. 7). Tal como en otro momento se comentó a propósito de una de las piezas de Santarém, acerca del motivo que llevó a su exclusión del tipo Ovoide 1 (Almeida 2008: 87), en el 
caso del tipo Ovoide 3 la razón para no incluir los fragmentos dentro de las Ovoide 1 es que la supuesta moldura del cuello, propia de éste último tipo, es en realidad la parte inferior del borde, pues éste se presenta, tal y como hemos señalado, con un perfil macizo y sobresaliendo del cuello, así como con un surco o acanaladura de forma más o menos pronunciada en su área central. En los casos en los que se ha conservado el cuello, como por ejemplo en el no 1271 de Castro Marim, se puede verificar, que no existe la moldura o "baquetón" en el cue1lo. Además, el asa presenta una sección de tendencia circular, y no ovalada con surcos, como las que frecuentemente se documentan para las Ovoide 1. Menos evidente es el surco o acanaladura en el fragmento $n^{\circ} 1323$ de Castro Marim (Fig. 7), pero, no obstante, su aspecto macizo y destacado nos lleva a considerarlo como perteneciente al tipo 3, y a excluirlo de la Ovoide 1 o 6.

Los contextos cronológicos para los pocos ejemplares que conocemos se centran en el tercer cuarto del siglo I a.C. (Almeida 2008: 87), como puede verse en Santarém, Castro Marim y el pecio Grand-Conglué 3, $\mathrm{y}$ en todos surge recurrentemente asociada a otros tipos ovoides del Guadalquivir, teniendo su mejor expresión en el caso del citado naufragio (Liou 2001: 1102, Lám. J, 5). Su difusión es aparentemente más occidental, pero el pecio nos indica también que estos tipos se comercializaban ya a mediados del siglo I a.C. hacia los territorios itálicos o de la Galia meridional, donde es conocida la presencia de otros tipos ovoides del Guadalquivir.

\section{Ovoide 8 (fig. 8)}

Recientes excavaciones en el Patio de Banderas del Alcázar de Sevilla, bajo la dirección del Prof. M. A. Tabales Rodríguez han sacado a la luz un conjunto de edificaciones en opus africanum interpretadas como horrea portuarios cuyos rellenos de construcción se fechan entre 50 y 25 a.C. De ellos procede un conjunto de piezas singulares con pastas del valle del Guadalquivir, muchas de ellas de tendencia ovoide, que no se dejan clasificar en ninguno de los tipos definidos hasta ahora en la región, por lo que en una publicación anterior, pareció oportuno definirlos con una nueva designación (García Vargas e.p. : 10-11 y fig. 10). Se ha optado por el sencillo sistema de continuar la seriación recientemente establecida para los tipos anfóricos minoritários del Guadalquivir, a raíz de la evidencia documentada en Santarém (Almeida 2008), que termina con la $n^{\circ} 7$, añadiéndole de este modo tres nuevas formas:

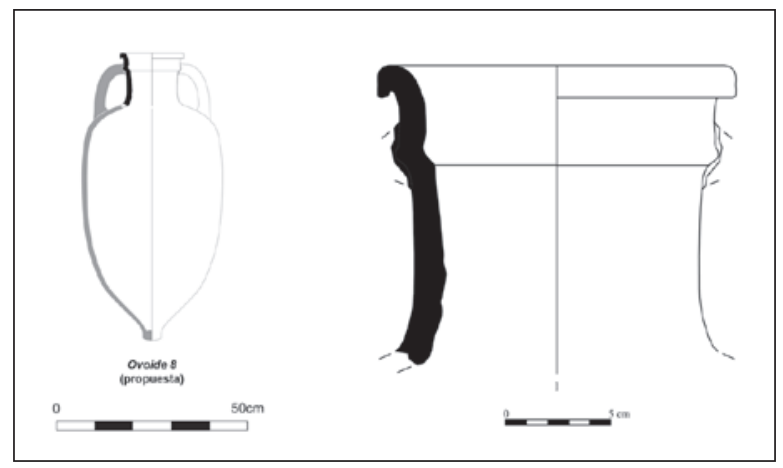

Figura 8. Tipo Ovoide 8. Propuesta de prototipo y fragmento procedente del Patio de Banderas del Real Alcázar de Sevilla.

los tipos 8, 9 y 10. Éstos se hallan representados de momento en su mayoría por los ejemplares del Patio de Banderas, pero se conocen ya nuevos ejemplares, algunos publicados y otros todavía inéditos, identificados en lugares de consumo de la fachada atlántica lusitana. Creemos que su "personalidad morfológica" es lo suficientemente acusada, como para justificar su asignación a tipos nuevos de los que, no obstante, se desconoce aún el perfil completo.

Un fragmento de ánfora republicana del Guadalquivir procedente de las citadas excavaciones sevillanas, presentan peculiaridades formales que pensamos que aconsejan su consideración como una nueva forma anfórica. Se caracteriza por tener un cuello similar al de las producciones definidas como Ovoide 5 (infra), de las que sin embargo se diferencia por el tratamiento del borde y del cuello, que carece de la tradicional moldura o "collarín", tan característica tanto de la Ovoide 1 (Clase 67/LC 67) como de la Ovoide 5. En efecto, lo que en el tipo que nos ocupa ahora puede confundirse con esta moldura, no es más que la parte inferior del mismo borde que, en la parte de arriba se convierte en un labio triangular ligeramente caído. Por su parte, dicha parte inferior crea una moldura en forma de filete, por lo que puede considerarse que estamos ante bordes altos muy moldurados y no ante molduras en el cuello.

El ejemplar del Patio de Banderas conserva todo el diámetro de borde y cuello completo carente de asas. El cuello es cilíndrico, algo más corto que la Ovoide 5 (infra) y las asas se insertan justo en la moldura inferior del borde, lo que constituye una nueva diferencia con respecto a las ánforas del tipo Ovoide 5 cuyas asas se integran en el cuello siempre por debajo del anillo medial. Estas características son las que nos llevan a la propuesta de reconstrucción que se presenta en la Fig. 8. 
Ovoide 9 (fig. 9)

Dos cuellos completos (nos. inv. 693 y 694) con borde, arranque de las asas y hombros procedentes del desmonte de unos testigos relacionados estratigráficamente con el edificio de africanum de la excavación del Patio de Banderas (García Vargas e.p.) (50-25 a.C.) son también de difícil asignación según las tipologías al uso, si bien es indudable, en función del color y aspecto macroscópico de sus pastas, que pertenecen a tipologías republicanas del Guadalquivir.

Ambas piezas presentan borde alto subtriangular con un pequeño resalte en los extremos exteriores superior e inferior, lo cual da a los bordes un ligerísimo aspecto moldurado. La parte alta del interior del borde presenta, además, una tenue línea de carenación, mientras que la base exterior del mismo es plana y ligeramente biselada. Los hombros son rectos y parecen sugerir para el cuerpo un perfil ovoide similar o cercano a los de las series ovoides que estamos describiendo. Es por esta razón por la que, siguiendo el ejemplo de publicaciones anteriores de este mismo material (García Vargas e.p.), los incluimos provisionalmente dentro de las ánforas locales de morfología ovoide, dándoles el $\mathrm{n}^{\mathrm{o}} 9$ en su clasificación. Un paralelo bastante próximo de esta forma lo encontramos una vez más en Apulia, en concreto en la variante B de la forma VII de los hornos de Apani (Palazzo 1988: 112-113; Palazzo 1989: 549 y $553^{13}$ ), una forma que arranca a finales del siglo II a.C. y de la que tal vez constituyan una variante provincial. Las asas de los ejemplares de Sevilla son muy fragmentarias, aunque el fragmento conservado de una de ellas en el ejemplar 693 sugiere la presencia de una acanaladura dorsal.

Un fragmento de bordes sin asas de la UE $1692\left(\mathrm{n}^{\circ}\right.$ inv. 2126) del Patio de Banderas (fig. 9 abajo dcha.), encuadrable en las mismas fechas, podría representar una variación interna del tipo (García Vargas e.p.) que, al igual que todos los demás tipos ovoides tendría cierto grado de variabilidad intrínseco. No obstante, siendo la morfología de éste último borde ligeramente diferente a las de los dos ejemplares anteriores, menos engrosado internamente, la superficie cóncava en su cara externa, el cuello muy corto y de tendencia cilíndrica, así como la ubicación de los arranques de asa, permiten afirmar que se está en presencia de un fragmento que se puede atribuir al tipo. Lo mismo proponemos para un fragmento procedente del Castelo da Lousa, fechado entre

13. cf. de forma complementaria la dirección http://www.dscc. uniba.it/Anfore/Leanfore.html.
40 a.C. y época augustea, aunque clasificado como Dressel 12 (Morais 2010a: 214, Estampa XXXVI.82), y para otro fragmento de la colección del Alto dos Cacos, un yacimiento con evidentes connotaciones militares, localizado muy cerca de la ciudad de Scallabis (Santarém), pero en la orilla opuesta del Tajo (Pimenta, Mendes y Almeida e.p.: Estampa 2.11).

\section{Tipo 10 (figs. 10-12)}

Una boca con cuello y arranque del asa del foro de Valeria publicado recientemente por uno de nosotros (González Cesteros 2010) presenta unas características realmente singulares, lo que nos ha aconsejado siempre clasificarlo aparte, a pesar de su "aire de familia" con las Haltern 70 iniciales y con otras ánforas de morfología ovoide (González Cesteros 2010: 33; González Cesteros e.p.; García Vargas e.p.). Sólo se conserva el tercio superior del recipiente, incluyendo un asa casi completa. El borde es rectangular, de unos 2 $\mathrm{cm}$. de altura, completamente recto con respecto al cuello y ligeramente convexo en su parte interna (González Cesteros e.p.). El asa se une al cuello por debajo del borde y presenta un ligero codo redondeado y acanaladura dorsal, lo que resulta común a la práctica totalidad de las producciones republicanas del Guadalquivir. El interior del cuello está marcadamente acanalado. Por lo demás, sus rasgos morfológicos permiten relacionarla con otros fragmentos de diversa procedencia que tienen un cuello y un perfil del borde similares. Entre ellos, destacan un par de cuellos sin asas procedentes del alfar tempranoaugusteo excavado en la calle Doctor Fleming nos. 13-15 de Carmona (García Vargas e.p.: Fig.10.2-3), en el que las tipologías mayoritarias son Pellicer D y Haltern 70.

En un trabajo anterior, uno de nosotros (García Vargas 2010: 594) había asimilado estos últimos fragmentos de Carmona con la forma definida como Ovoide 2 del Guadalquivir (Almeida 2008: 83-85), pero la posterior constatación de su cercanía morfológica con el ejemplar de Valeria, (cf. González Cesteros 2010; González Cesteros e.p.), más completo, aconsejó luego darles un nombre propio: el de Ovoide 10 del Guadalquivir (García Vargas e.p.). A la postre, este nombre puede ser también inadecuado, ya que no existe seguridad de que perteneciera a un tipo/cuerpo de morfologia ovoide.

Un examen atento de las piezas en cuestión, permite tentativamente establecer un vínculo formal entre estas piezas (con seguridad la de Valeria) y las ánforas tardorrepublicanas apulas y medio-adriáticas del 

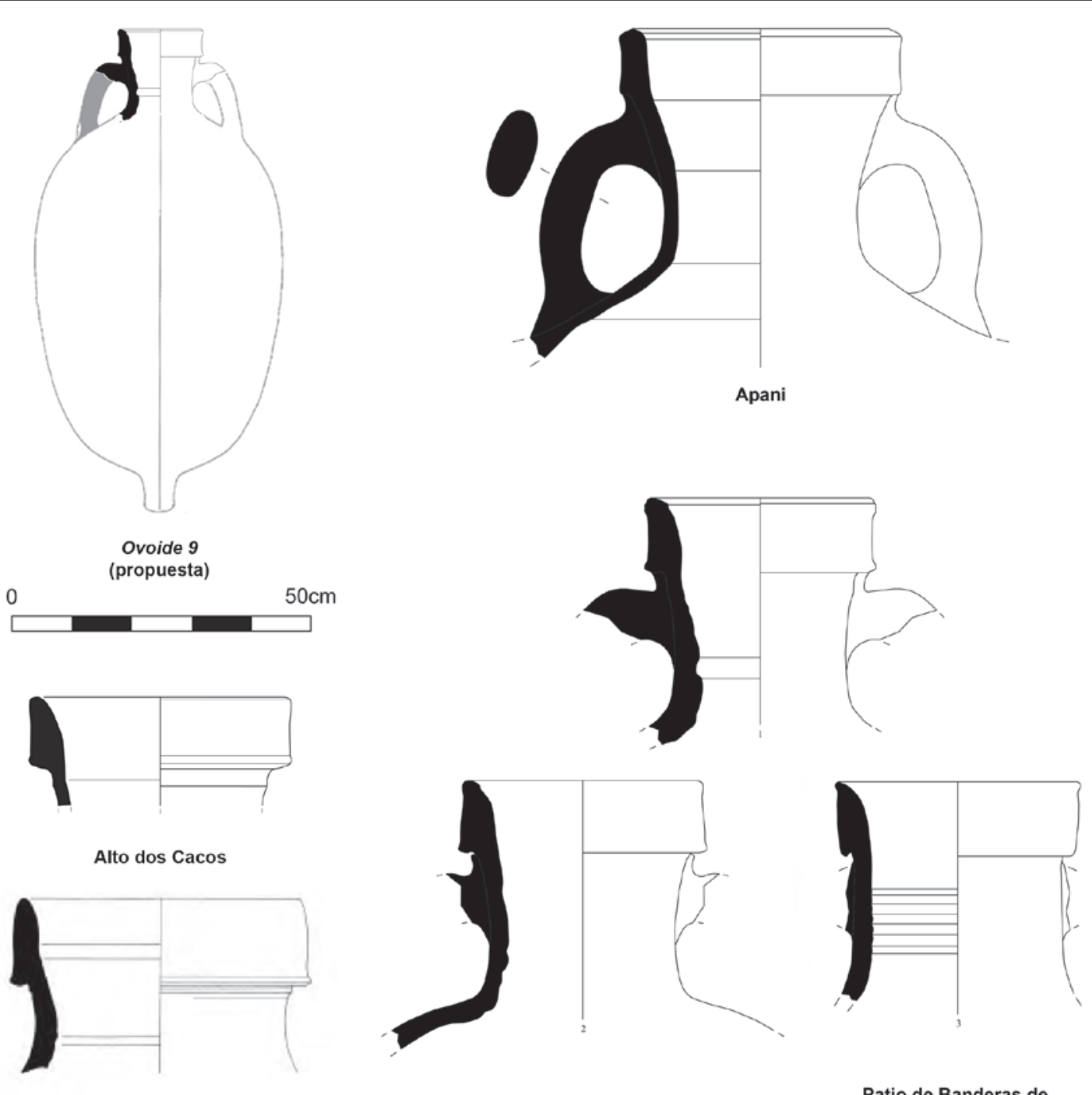

Patio de Banderas de

Castelo da Lousa

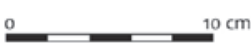

los Alcazares de Sevila

Figura 9. Tipo Ovoide 9. Propuesta de prototipo y ejemplares fragmentarios.

tipo Lamboglia 2. Este es un hecho que ya se apuntaba también en trabajo anterior (García Vargas e.p.), en el que se señalaba que, aunque la apariencia general parecía relacionarse con la de las Haltern 70 "iniciales", se separaban de éstas en la forma del borde y en el perfil y longitud del cuello y asas (sobre todo estos dos últimos aspectos), detalles morfológicos que recuerdan bastante a los característicos de los tipos asimilables a la forma Lamboglia 2 o sus sucesoras directas, las Dressel 6 adriáticas. Concretamente, a modo de ejemplo, piezas como las ilustradas en la Figura 10 y procedentes de Herdonia (Stefano 2008: 120, tav. XXIV), o en la Figura 11, algunos de los muchos fragmentos recuperados en Cartagena (Márquez Villora y Molina Vidal 2005: figuras 50-54) nos parecen especialmente próximos al de Valeria, con la salvedad de que el ánfora del Guadalquivir tiene unas dimensiones reducidas con respecto a las de la serie "original" de Lamboglia 2.

La relativa "miniaturización" de los contenedores de imitación, parece, por otra parte, característica de algunas series de ánforas "vinarias" del valle del Guadalquivir como las Dressel 1 de La Loba o de Posadas (supra), lo que puede constituir un argumento más para sostener una conexión formal con ánforas itálicas 


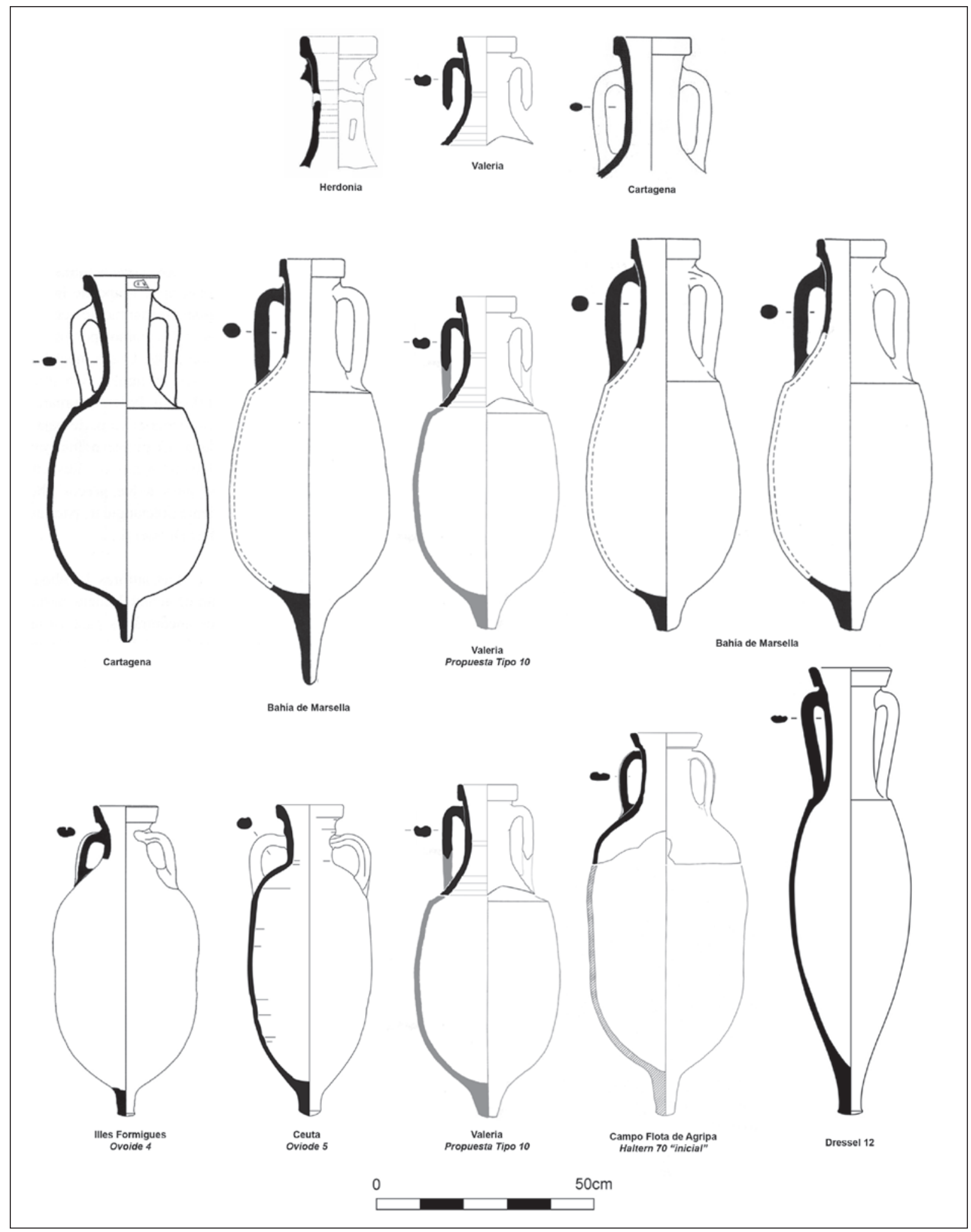

Figura 10. Comparación entre el ejemplar de Valeria y bocas de Lamboglia 2 (arriba), propuesta de reconstitución del Tipo 10 y comparación con ejemplares completos de Lamboglia 2 (medio), comparación entre la propuesta del Tipo 10 y otros tipos (ovoides del Guadalquivir, Haltern 70 y Dr 12). 


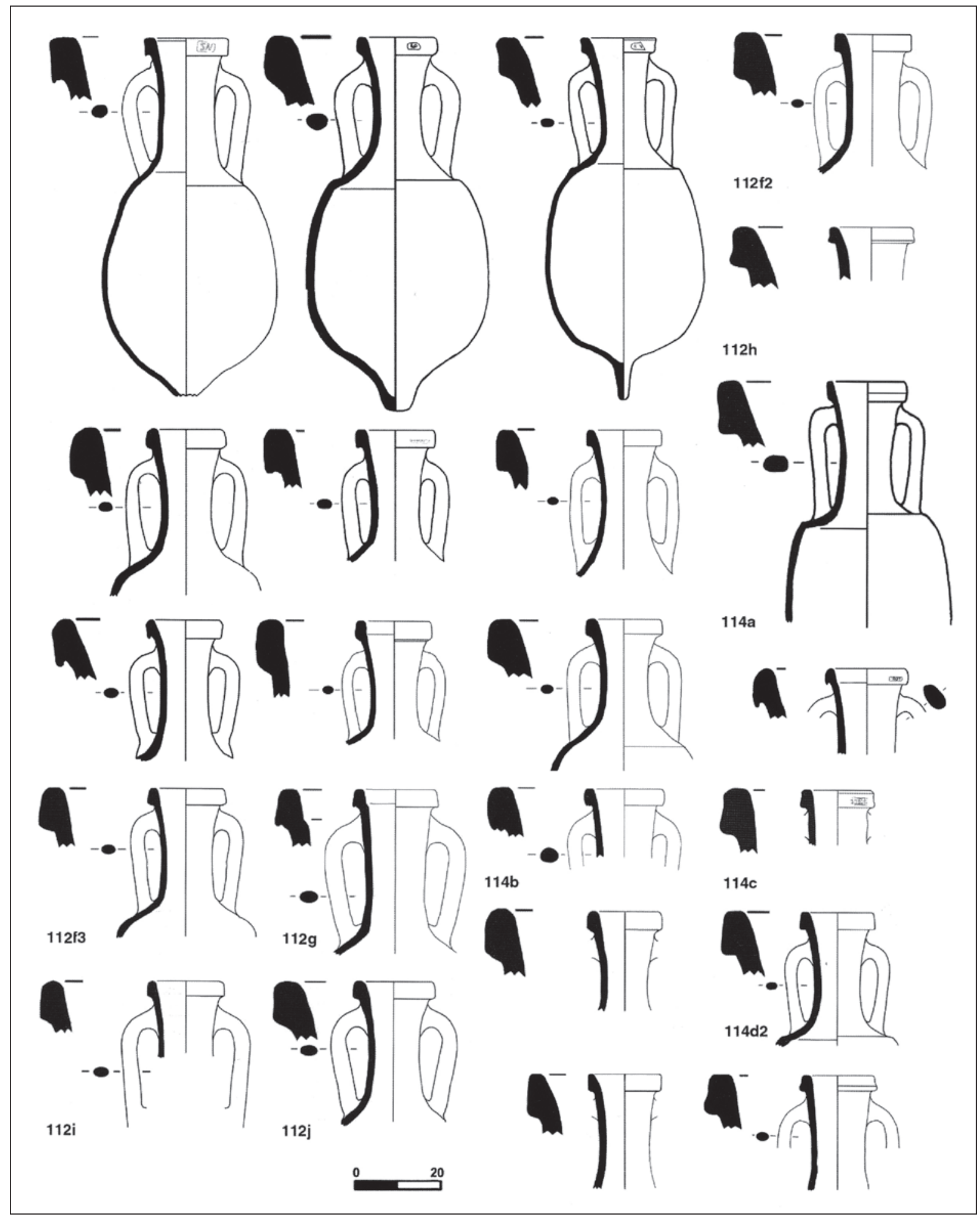

Figura 11. Ejemplo de la variablidad formal dentro del tipo Lamboglia 2. Fragmentos procedentes de Carthago Nova (según Márquez Villora y Molina Vidal 2005). 


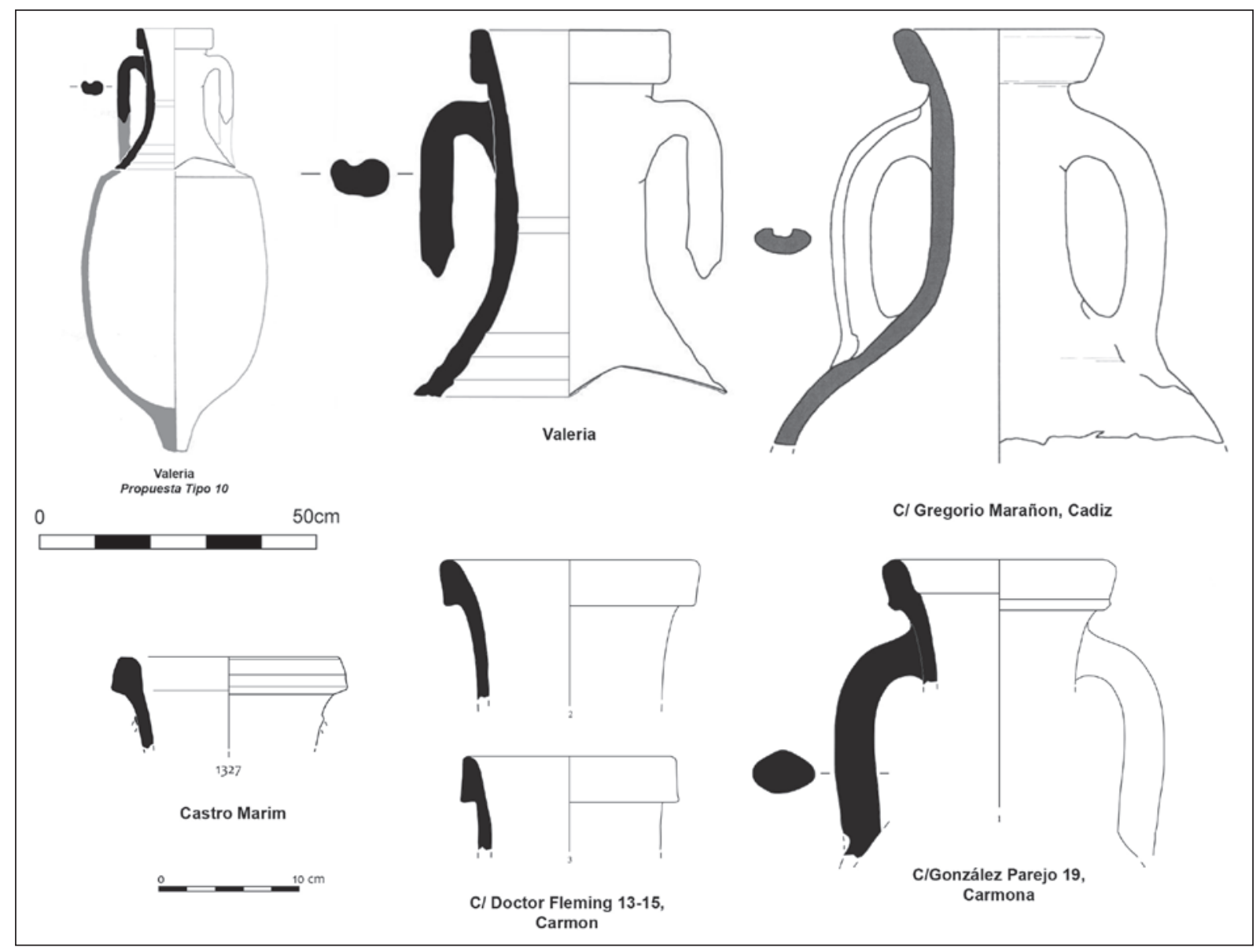

Figura 12. Propuesta de reconstitución del Tipo 10, ejemplares fragmentarios y variantes adscribibles al tipo.

contemporáneas de nuestros ejemplares de Valeria y Carmona. De momento, y con la provisionalidad a la que obliga la precariedad de nuestros datos, mantendremos el $n^{\circ} 10$ que ya le otorgamos a la denominación de estas ánforas, pero suprimiendo la indicación "ovoide", de modo que, nos referiremos a ellas como Tipo $10 \mathrm{del}$ Guadalquivir.

De cualquier forma, queremos subrayar el hecho de que los fragmentos comentados que proceden de contextos muy diversos, sin ser numerosos, parecen sugerir un "horizonte" de imitaciones regionales de ánforas Lamboglia 2 o al menos de producciones anfóricas inspiradas en esta morfología de origen itálica meridional y/o adriática. En 1998, uno de nosotros (García Vargas 1998: 345, fig. 27.3) publicó un diseño de ánfora Lamboglia 2 procedente de las excavaciones en el alfar tardopúnico de la calle Gregorio Marañón de Cádiz. Dado el estado entonces de la investigación, no la atribuimos a una producción regional, puesto que, además, fue imposible localizarla entre los materiales procedentes de la intervención que consultamos en el Museo de Cádiz. Años después, y reparando en la forma del asa, con la característica acanaladura y digitación terminal de unión al hombro, nos planteamos que pueda tratarse de una interpretación regional de la forma adriática, a lo que parece que conducen también las peculiaridades del borde. La fase siguiente del mismo solar presenta ánforas Dressel 9 de producción local y época augustea con asas acanaladas, con lo que quizás la pieza anterior sea una manufactura de la propia figlina. Ante la imposibilidad de asegurar nada al respecto con el simple dibujo del ejemplar, lo traemos aquí solamente como ejemplo comparativo y como posibilidad de estudio en el futuro con respecto a una línea morfológica influenciada por las Lamboglia 2 en el sur de la Ulterior.

Dentro de esta línea de influencia de Lamboglia 2 vemos ahora como próximo al tipo 10 un ejemplar del alfar de González Parejo no 19 de Carmona que uno de 
nosotros publica en una trabajo anterior como Ovoide 3 (García Vargas e. p.) dadas las peculiaridades de su borde. La forma del cuello y las concomitancias generales con las ánforas inspiradas o que imitan a las Lamboglia 2, creemos ahora que justifican la reubicación tipológica de este cuello de Carmona en el interior de los contenedores del Tipo 10. Tanto la pasta cerámica, como el detalle de la digitación en la inserción inferior del asa, aseguran que se trata de un ejemplar manufacturado en Carmona, tal vez en el mismo alfar en el que fue documentado.

Otro de los nuevos fragmentos que integramos en este tipo proviene de Castro Marim. Aquí, procedente de la fase de ocupación tardorrepublicana comprendida entre 60-30 a.C.; este fragmento fue integrado en los tipos olearios antiguos (Viegas 2011: 493, Est. 104). Sin embargo, entendemos que la particular morfología de su labio y cuello son perfectamente compatibles con algunas de las morfologías "canónicas" conocidas para el tipo Lamboglia 2, y por lo tanto, se debe adscribir a este nuevo tipo del Guadalquivir.

\subsubsection{Tercer Grupo. Contenedores con éxito significativo en los mercados.}

Frente a los contenedores del grupo anterior, que alcanzaron una difusión muy limitada desde el punto de vista cronológico y espacial, por lo que pueden ser considerados como formas claramente minoritarias, los del presente grupo constituyen el núcleo morfológico y funcional a partir del cual se desarrolló el repertorio provincial bético de época imperial temprana (cf. apartado 2.1.4). Su "éxito comercial" es mucho mayor que el de las formas precedentes, siendo así que la mayoría, si no todos los tipos se constatan no sólo en yacimientos peninsulares, sino también en las costas del Mediterráneo occidental y en barcos hundidos que denotan las rutas marinas por las que eran transportadas.

Aunque el proceso de definición de las formas de este grupo ha sido largo y arduo (infra), puede decirse que, hoy por hoy, las características de cada uno de los tipos que lo conforman se encuentran prácticamente fijadas, sirviendo de referente claro a la investigación sobre el comercio de alimentos en ánforas durante los años finales de la República Romana. La ordenación tipológica de esta serie ofrece, al mismo tiempo, referencias cronológicas importantes para la datación de las secuencias estratigráficas tardorrepublicanas en las que comparecen, a condición de que sepan distinguirse de los ejemplares, a menudo formalmente muy semejantes, que constituyen el grupo siguiente (2.1.4). Los tipos de éste último derivan directamente de las formas del grupo que ahora tratamos, dándose las siguientes derivaciones: Ovoide 4 - Haltern 70; Ovoide 6 (Clase 24) - Oberaden 83. Obsérvese que las ánforas de la forma Ovoide 1 (Clase 67/LC67) desaparecen sin dejar "sucesora" en la fase siguiente.

\section{Ovoide 1 (=Clase 67 / LC67) (figs. 13-14)}

Existe actualmente el consenso generalizado de que, de entre las ánforas de morfología ovoide tardorrepublicanas de producción hispánica, el tipo recientemente agrupado en el repertorio del valle del Guadalquivir como Ovoide 1 es probablemente el mejor conocido, y simultáneamente el mejor ejemplo hispano resultante de la creación de un repertorio de ánforas propio con características occidentales, pero con clara inspiración romana.

Aunque estas ánforas ovoides de cuello y asas cortos, borde almendrado y collarín o moldura bajo el borde en la separación con el cuello, son conocidas en la literatura arqueológica desde hace decenios (Lamboglia 1955: figs. 15 y 16; Callu y otros 1965: 100-101; Domergue 1973; Nolla Brufau 1974-1975: 170 y figs. 16.4; Boube 1979-80: 100), su reconocimiento como un tipo singular no tuvo lugar hasta el trabajo de C. Fabião sobre las ánforas del campamento romano de la Lomba do Canho (Arganil), donde las denominó Clase 67 (Fabião 1989: 65-73), añadiendo una clase más a la tipología abierta establecida algunos años antes por Peacock \& Williams (1986). Sin embargo, el escaso uso de la tipología británica en el ámbito de la investigación peninsular llevó a que se generalizara con posterioridad en la bibliografía de referencia como LC67 o Lomba do Canho 67, de donde deriva su nombre. En los años noventa, J. Molina Vidal dio un nuevo impulso al conocimiento y consolidación de este tipo, atestiguando su presencia en contextos tardorrepublicanos del Levante español (Molina Vidal 1995).

Este tipo surge en un momento paralelo o inmediatamente posterior al de la "reproducción de los modelos itálicos", dentro de lo que se viene definiendo como el "proceso de romanización" de los contenedores (Fabião 1998a: 398). Dada su nula conexión formal con las morfologías anfóricas turdetanas, la producción de este tipo también podría ser entendida objetivamente dentro de la reproducción de los modelos itálicos . No obstante, no existen señales clareas de presencia de un prototipo itálico en Hispania del que surgiera esta forma 
directamente y sin variación, por lo que nos parece que sería mejor incluirlo en este grupo 2.1.3, compuesto por formas que surgen en un segundo momento de ese proceso de romanización del artesanado de transporte, posterior en todo caso al del grupo 2.1.1., correspondiente a la "reproducción de contenedores precedentes con demostrado éxito regional".

A pesar de que al principio se planteó un posible origen formal enraizado en las producciones púnicas occidentales (Fabião 1989: 66), se dejó igualmente abierta la posibilidad de que entroncara con las producciones brindisinas (Fabião 1989: 67). Esta última idea es la que viene prevaleciendo en los últimos 10 años de investigación. Las propuestas que se vienen avanzando sucesivamente van al unísono (Molina Vidal 2001: 641; Fabião 2001: 672; Bernal Casasola y Garcia Vargas e.p. ; Almeida 2008: 70; García Vargas e.p.) y son concordantes en cuanto que reconocen una estrecha conexión con el universo de los modelos itálicos ovoides de las regiones meridionales (Molina Vidal 2001: 641), un elenco formal igualmente problemático y de difícil caracterización. Éstos podrían ser concretamente las formas apulas Baldacci 1C (Baldacci 1972: 26-27 y Tav. 1.12) o las formas II/III y IV de los alfares de Apani (Palazzo 1988: tav. XXIX; Palazzo 1989), o, quizás con más probabilidad, los tipos medio-adriáticos del Piceno, con labios moldurados y con asas de características prácticamente idénticas a las del tipo hispánico, datados entre el cambio del siglo II al I y el 30 a.C. (Carre y Mattioli 2003: 459-460 y Tav. I), documentados por ejemplo en el alfar de Cesano de Senigallia (Cipriano y Carre 1989: 77-80) o en la colonia de Herdonia (Stefano 2008: 120, tav. XXIV), y que tienen sus mejores referencias en el naufragio de Palombina (Mercando 1975-81).

Independientemente del parecido con unos u otros tipos del repertorio itálico meridional, lo que parece estar claro es que se configura un contenedor de producción sudhispana, que se encuentra directamente vinculado con otros tipos tardorrepublicanos suditálicos y que este hecho, lejos de ser un fenómeno aislado, va a marcar tendencia en una Hispania meridional, que parece ir progresivamente introduciendo sus productos envasados en ánforas en los circuitos comerciales romanos (Molina Vidal 2001: 641).

En la cronología apuntada para las producciones itálicas, es coherente que el inicio de las (re)producciones hispanas sea, naturalmente, posterior a la de sus modelos itálicos. En lo referente al posible marco cronológico para el arranque de su producción, dado que no existe ningún tipo de evidencia directa para el valle del Guadalquivir, los escasos datos sólidos cobran sentido a partir de los que se pueden inferir de los centros de consumo y, complementariamente, de otras regiones hispanas que produjeron tipos similares, con todos los peligros que conlleva el uso de dichos paralelismos. Por su parte, los lugares de consumo nos muestran unas primeras importaciones hacia los años finales del primer tercio del siglo I a.C., propuesta al principio por Fabião (Fabião 1989), y confirmada después por Molina Vidal en yacimientos del Levante peninsular (Molina Vidal 1995; 2001), por lo que creemos que el inicio de su producción debió de ser por estas fechas.

La evidencia disponible certifica que el período de máxima producción y exportación se sitúa indiscutiblemente en el tercer cuarto de esta centuria. Es lo que se puede deducir de su exportación mediterránea (Molina Vidal 2001: 640), y de varios naufragios que documentan su circulación en los grandes ejes comerciales para esas fechas -Grand-Conglué 3 (Liou 2001: 1091, Lám. J-K), San Ferreol (Mas García 1985: 205) o Rabat (Boube, 1979-1980)- pero sobre todo de su ya acentuada difusión en el extremo occidental del Mediterráneo, con una particular concentración en la fachada atlántica peninsular y en sus áreas de penetración más inmediata (Fabião 2001; Almeida 2008; Almeida 2010). Su desaparición de los entornos productivos y de los mercados parece ocurrir en torno a los últimos decenios del siglo (Molina Vidal 2001) o inclusive en el inicio del primer tercio del siglo I d.C., con base en los materiales de Santarém (Almeida 2008: 82).

En cuanto a la geografía de la producción, resulta paradójico que el ánfora más exportada de la Ulterior republicana sea "opaca" a efectos de centros concretos de producción en el Valle del Guadalquivir, no conociéndose ningún alfar que haya producido este tipo (Almeida 2008: 72), aunque sí referencias orales (Prof. O. Arteaga Matute) acerca de una serie costera procedente de los alfares no excavados de Toscanos (Vélez Málaga). Si esto es así, las producciones más antiguas podrían haber sido la de los alfares malagueños y gaditanos (Lagóstena Barrios y Bernal Casasola 2004) junto con la de ánforas Dessel 1 y "Ovoides gaditanas", mientras que en el área gaditana, su aparición y producción parecen encontrarse vinculadas a los alfares ubicados en el ámbito rural y relacionados con propiedades fundiarias de tipo villae. En todo caso, las cronologías aceptadas en ésta última zona no van más allá de mediados del siglo I a.C., estando por el momento ausentes de los contextos productivos periurbanos más 


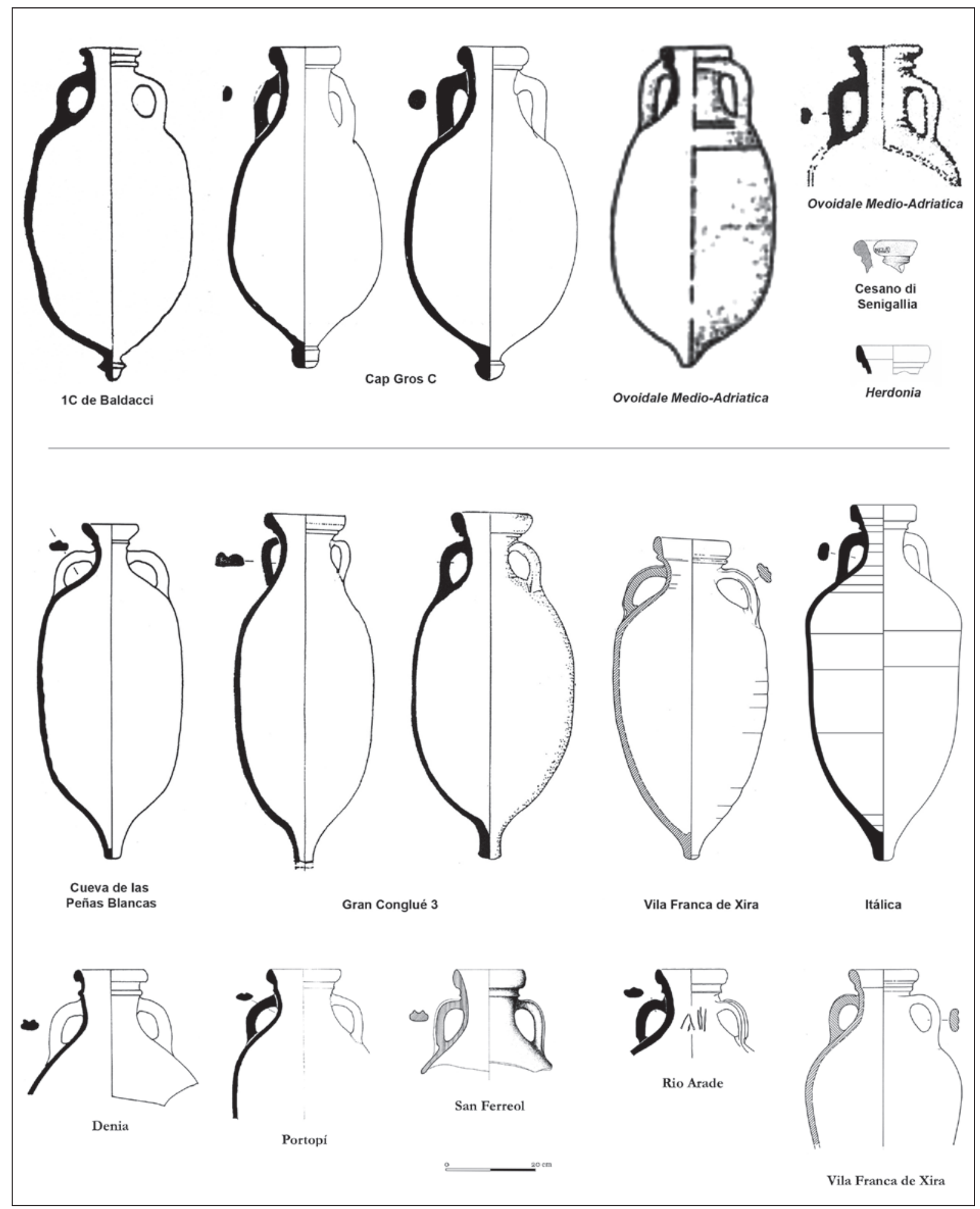

Figura 13. Ánforas ovoides de producción sud-itálica, protótipos de la Ovoide 1 del Guadalqivir (arriba) y ejemplares completos y semi-completos de Ovoide 1 (=Clase 67/LC67) (abajo). 
antiguos, como los de la isla de San Fernando (Cf. García Vargas 2001: 64).

También parece haber series costeras del tipo en la bahía de Algeciras y la Tingitana atlántica. En la primera de estas dos regiones, su producción se encuentra atestiguada en El Rinconcillo únicamente a partir de la fase III (Fernández Cacho 1995: 183, lám.4 nº s 3-5), cronológicamente mal caracterizada y que, pese a propuestas recientes de una mayor antigüedad (Bernal Casasola y Jiménez-Camino Álvarez 2004) nos inclinamos a fechar en el tercio central del siglo I a.C. . Por su parte, también se encuentra documentada la producción en el yacimiento marroquí de Sala hacia mitad del siglo I a.C. (Boube 1987-88).

Este panorama dispar, entre producción interior y litoral para el tipo ${ }^{14}$, y esto último en ambas costas del Estrecho, contrasta enormemente con el panorama de los contextos de consumo del siglo I a.C. donde se señala explícitamente procedencia de los fragmentos. En ellos, la gran cantidad de especímenes muestran las típicas pastas con desgrasantes detríticos sedimentarios del valle del Guadalquivir, cercana al 90/95\%, lo que aboga por un escenario productivo mayoritario centrado en el bajo valle del Baetis. Esto es lo que se desprende en el numeroso conjunto de yacimientos de la Citerior (Molina Vidal 2001: 638) y de la franja costera de la propia Ulterior, principalmente en el espacio del territorio actualmente portugués, en sitios como Lomba do Canho (Fabião, 1989: 60ss), Castro Marim (Arruda 1996; Arruda y otros 2006b; Viegas 2011: 487-488), Faro (Viegas 2011: 201), Santarém (Arruda y otros 2005: 286; Almeida 2008), y otros de menor entidad más al interior, sobre todo en el Guadiana, como es el caso de Castelo da Lousa (Morais 2010a), y en el Alentejo Central (Mataloto2008).

Tal como ocurre con los demás contenedores ovoides, el tipo Ovoide 1 carece de evidencias claras acerca de su contenido habitual, si es que fue sólo uno. En la primera caracterización realizada por $\mathrm{C}$. Fabião, se avanzó la propuesta de que se destinaran al transporte de contenidos piscícolas (Fabião, 1989: 66-68), sobre la base, sobre todo, del supuesto titulus del naufragio de San Ferreol (Mas García, 1985: 205).

14. Las formas anfóricas con series costeras y del interior, como las LC 67 y las Clase 24, plantean un problema de denominación que resolveremos en lo sucesivo de forma simple: cuando esté constatado un origen litoral para un fragmento o un ánfora completa, utilizaremos la denominación genérica LC 67 y Clase 24, lo mismo que si la pieza es cuestión es de origen dudoso. Sólo en el caso de que la manufactura en el valle del Guadalquivir sea evidente, utilizaremos la nomenclatura regional: Ovoide 1 y Ovoide 6 respectivamente.
Posteriormente, C. Fabião (2001: 673) y otros autores establecieron que, al igual que para otros tipos anfóricos pre-augusteos, la propuesta más probable sería que se tratase de contenedores con un carácter polivalente, habiendo servido para difundir diferentes artículos (García Vargas 2001). Esta misma premisa justificaba la posibilidad de diferentes contenidos en función de los distintos ámbitos de producción, en la estela de lo sugerido por otros autores (García Vargas 2001; Bernal Casasola y García Vargas e.p.). Por lo tanto, si bien es cierto que su producción en las alfarerías costeras y la forma de sus bocas incita a pensar en un contenedor para preparados piscícolas (tal como indica el referido titulus pictus del naufragio de San Ferreol), o que su producción en la costa atlántica marroquí puede reforzar esa posibilidad de utilización para el transporte de preparados piscícolas, pensamos que en el caso de las producciones del Guadalquivir, aunque se podrían considerar igualmente su uso para envasar salazones resultantes de ámbito fluvial o lacustre, la distancia a la costa sugiere un contenido diferente, probablemente aceite o vino. En esta última dirección indica, la morfología particular de estos contenedores, de evidentes similitudes formales con las ánforas itálicas meridionales y medio-adriáticas, especialmente con las apulas, lo que hace pensar en el aceite, un producto abundante en el valle del Guadalquivir ya incluso desde momentos precedentes, como la referencia obligatoria. Esta ánfora podría así haber constituido uno de los primeros vehículos de exportación del aceite bético, tan afamado y difundido de forma masiva en los decenios y siglos inmediatamente posteriores (Almeida 2008: 194-195), aunque tampoco se pueda descartar el vino o el defrutum como posibilidades.

No obstante, para volver a dar una tuerca más a la discusión acerca de su contenido, hay que mencionar que recientemente se ha (re)lanzado la propuesta de su posible relación con el contenido de salazones, pero esta vez de ámbito costero. Su abundante presencia en Castro Marim, particularmente en un contexto fechado entre 60-30 a.C. (Arruda 1996: 99), permitió reabrir la discusión, ya que se admite la posibilidad de diversos productos, pero se apunta al contenido piscícola basándose en los opérculos recuperados en dicho contexto, cuya analítica demostró un origen petrográfico en la bahía gaditana (Arruda y otros 2006b: 173), defendiéndose que estas ánforas manufacturadas en el Valle del Guadalquivir se transportarían vacías hasta la costa, donde se habrían rellenado y sellado con opercula de producción local. Creemos que se trata de una lectura problemática que, 


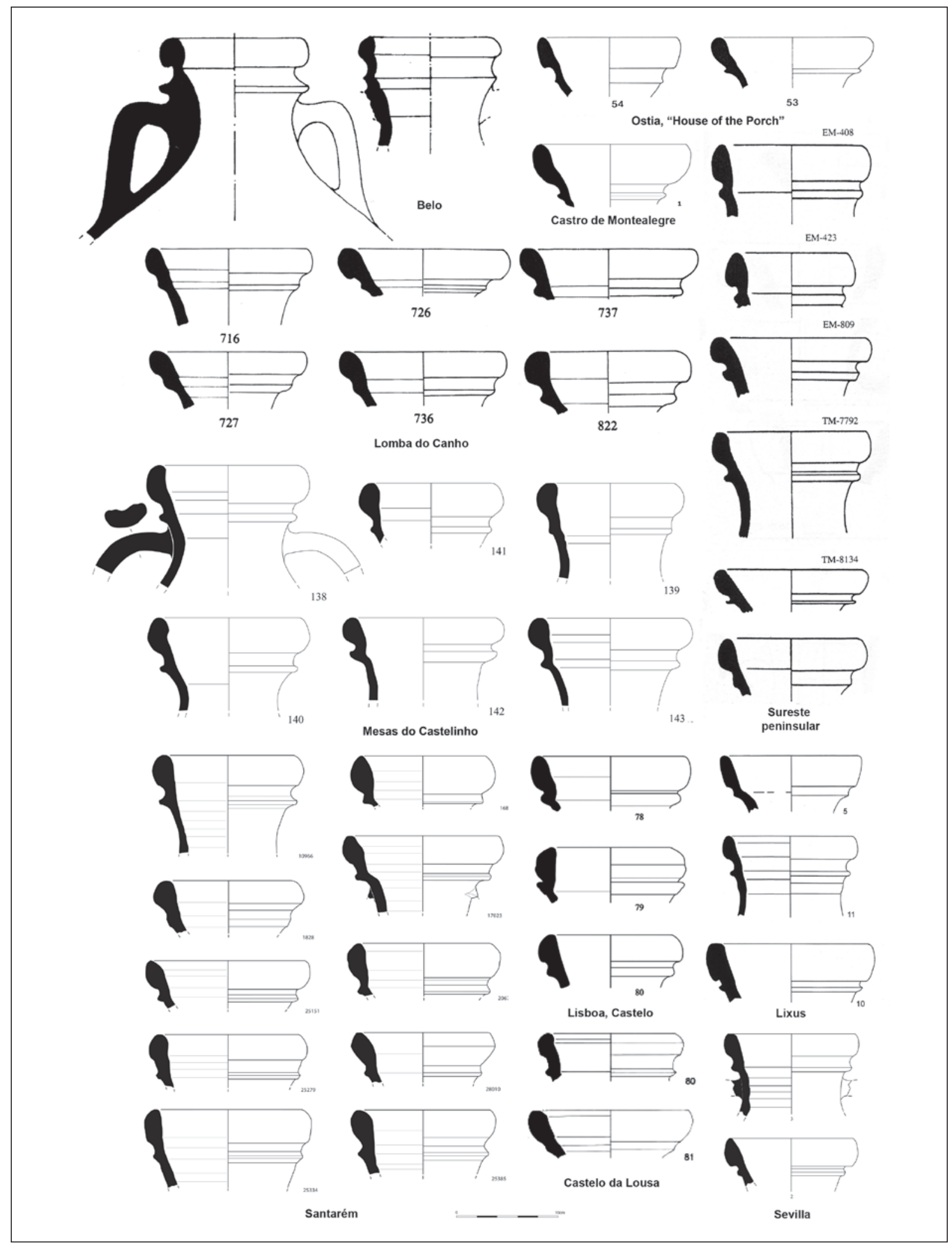

Figura 14. Ánforas Ovoide 1 del Guadalquivir. Fragmentos de algunos contextos significativos. 
no obstante se debe mantener abierta como hipótesis de trabajo futuro ${ }^{15}$.

En el reciente trabajo monográfico de síntesis realizado por uno de nosotros (Almeida 2008), se actualizó el mapa de difusión de este tipo, y se concluyó que desde el momento de su definición había crecido de forma muy significativa el número de localizaciones geográficas asociadas a la forma, por lo que se iba alejando ya de la condición de tipo minoritario (Almeida 2008: 72-76). Este mapa, que se encuentra actualmente en revisión, se ve ampliado con algunos sitios más, pero, sin embargo, poco cambia en lo que se refiere a sus principales aspectos y a las lecturas y propuestas entonces realizadas acerca de la difusión del mismo.

A pesar de que la comercialización de la Ovoide 1 no parece ser porcentualmente significativa en relación con el total de ánforas documentadas en los contextos del Mediterráneo, su recepción es un hecho incuestionable tal como lo demuestra su exportación hasta parajes lejanos, estando presente en Cesarea Marítima, en niveles herodianos (Oren-Pascal y Bernal Casasola 2001: 993, fig.4c), en Éfeso (Bezeczky 2004: 86, fig. 18), en Ostia en el depósito de la Casa del Pórtico en el tercer cuarto del siglo I a.C. (Van den Werff 1986), en Albintimilium, (Lamboglia 1955: 259-269), Vieille Toulouse (Fouet 1958), Fréjus (Février 1956: 52 y fig. 16) o en Lyon, en el yacimiento conocido como Cybèle, en contextos de 40-20 a.C. (Desbat y Lemaître 2001: 801, fig.1.11).

En la mitad oriental de Hispania (Cf. Almeida 2008: 77-76 y Mapa-Figura 17) se convierte en un tipo profusamente exportado en la segunda mitad del siglo I a.C., con documentada presencia en toda la Tarraconensis desde su cuadrante nororiental (Ampurias, en

15. Los distintos tipos de opercula conocidos para el cierre de las ánforas presentan medidas y morfologías cercanas, pudiendo además ser utilizados indistintamente en varios tipos, o por lo menos en más de uno. Independientemente del aspecto exterior de las bocas de las ánforas, el cierre se realiza en la parte superior del interior del cuello, y, a mayor o menor distancia desde la línea de la boca, los opercula encajan prácticamente en la mayoría de los tipos conocidos. De no ser así, se perdería el carácter práctico y "universal" del opérculo, o de otros elementos de cierre. En última instancia, la manufactura en un mismo alfar de distintos tipos o de un repertorio anfórico con significativa variabilidad conllevaría a la fabricación de idéntica proporción y variabilidad tipológica de los elementos de cierre. Asimismo, lo más probable es que los opercula hubiesen llegado acompañando a tipos anfóricos procedentes de la misma región productora, pues éstos están presentes en número igualmente significativo en dichos contextos, nos referimos a las Maña C2b (T-7.4.3.3), las Dressel 1, las Clase 67/LC67 y las Dressel 7-11 con morfologías antiguas, todos ellos de la costa, a los cuales se les aplica los mismos tipos de opérculos (Bernal Casasola y Sáez Romero 2008: 467-469).
Baetulo, en Tarraco y posiblemente en Iluro), y documentándose también su presencia a lo largo del principal curso fluvial navegable, el Ebro (Celsa), hasta el sureste de la provincia (Valentia, en los contextos de la Plaza de La Reina y las Corts Valencianes), en prácticamente todos los yacimientos con ocupación tardorrepublicana como Punta del Arenal, Duanes (Alicante), El Monastil (Elda), Lucentum, Ilici, El Molinete (Cartagena), Loma de Herrerías (Mazarrón, Cartagena), o la Cueva de las Peñas Blancas, en claro contraste con los yacimientos de fundación augustea, como por ejemplo el Portus Ilicitanus (Molina Vidal 1997; Molina Vidal 2001: 683; Márquez Villora 1999; Márquez Villora y Molina Vidal 2001).

En la propia provincia de la Ulterior, la zona litoral es mucho más rica en hallazgos, destacando Cerro del Mar, con su famosos "complejos 10 y 11", que van desde mediados del siglo I a.C. a inicios del principado (Arteaga Matute 1985: 216-222), donde tal vez sean de producción local, y en Baelo Claudia desde mediados del siglo I a.C., pudiendo todavía encontrarse aún en el comienzo del período imperial (Domergue 1973: 109). En Cádiz y en su área de influencia inmediata, sólo se conoce un escaso número de ejemplares importados en la Casa del Obispo, en La Milagrosa (San Fernando) y en el Convento de las Concepcionistas (Vejer de la Frontera), en una interesante asociación fechada en el último cuarto del siglo I a.C., constituida por ánforas ovoides gaditana, Ovoide 4 y Oberaden 83 u Ovoide 6 (García Vargas, 1998: 75).

En el mismo valle del Guadalquivir, además de los fragmentos identificados en la ciudad minera de $\mathrm{Mu}$ nigua (Fabião 2006: 106-107), el único ejemplar completo de Ovoide 1 publicado, que procede de un depósito anfórico de las cercanías de Itálica, y fechado en torno a la mitad del siglo I a.C., presenta un cuerpo ovoide con amplios hombros y ligeramente apuntado por la base (García Vargas 2010: Fig. 2.2.5., nº 3). Junto con él, se han dado a conocer varios fragmentos de la actual calle Alemanes $\mathrm{n}^{\circ} 25$, fechado uno de ellos entre 50 y 25 a.C., y apareciendo el otro de manera residual en un contexto del tercio central del siglo I d.C. (García Vargas e.p.). En el Patio de Banderas del Real Alcázar (García Vargas e.p.), nos encontramos este tipo en la UE 1911, datada también entre 50 y 25 a.C., ambas de la época de máxima comercialización del tipo.

Pero sin lugar a dudas es en la fachada atlántica donde podemos encontrar la concentración de hallazgos más grande, tanto en densidad como en número (Cf. Almeida 2008: 75 y Mapa-Figura 17). Destacan los hallazgos de Baesuris/Castro Marim (Viegas 2011), 


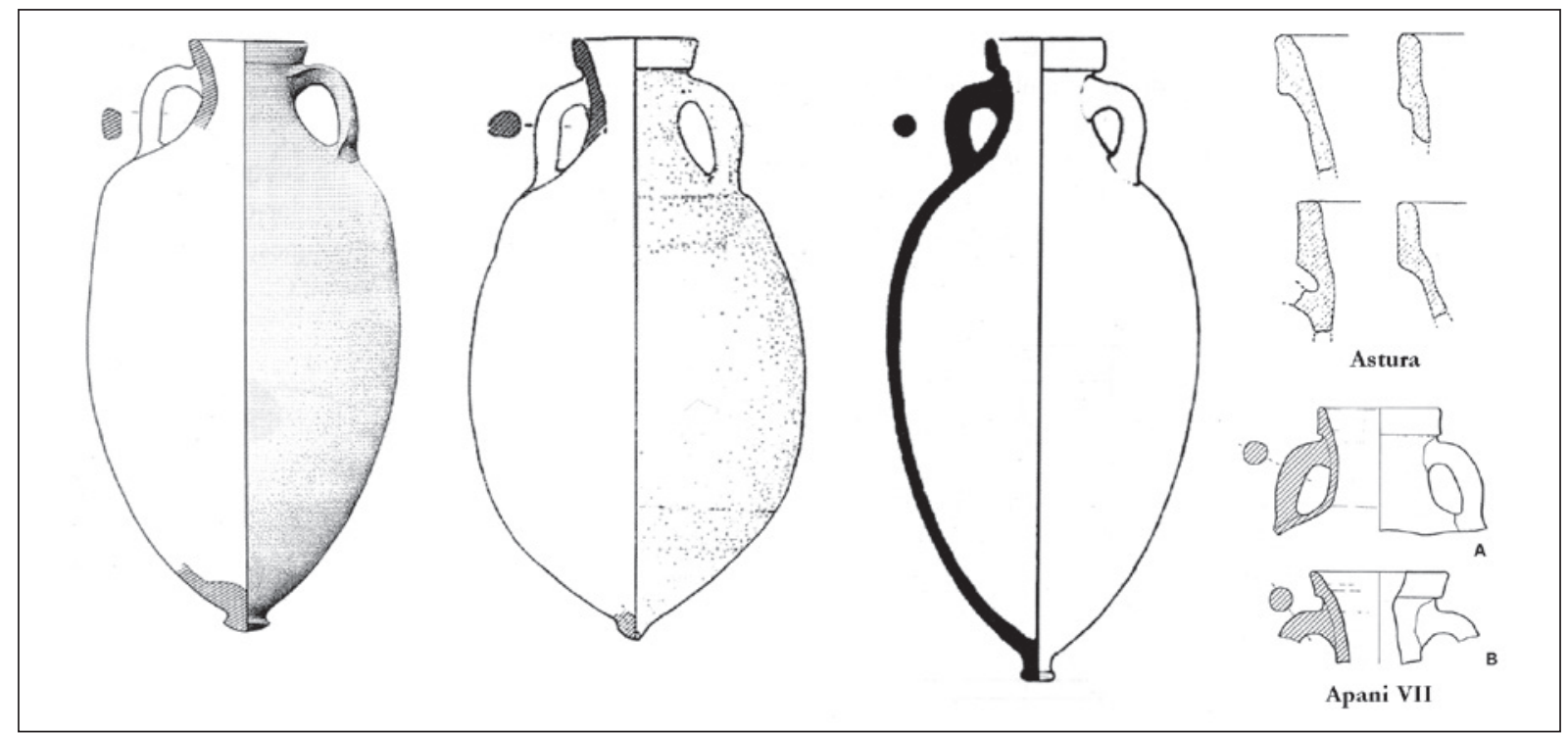

Figura 15. Ánforas itálicas de morfología ovoide, posibles prototipos del tipo Ovoide 4.

Osonoba/Faro (Viegas 2011) Scallabis/Santarém (Almeida 2008), Mesas do Castelinho (Fabião 2001; Parreira 2009), Lomba do Canho ( Fabião 1989), los castros de Vigo y de Santa Tecla (Peña Santos 1986), o aún el castro de Montealegre (González-Ruibal y otros 2007). La imagen disponible certifica que es desde la cuenca del Guadiana hasta la Gallaecia donde el tipo Ovoide 1 está bien presente, principalmente entre 6020 a.C., y en destinos con clara naturaleza militar o en contextos civiles militarizados ya que aparece en contextos civiles apenas en su momentos finales y sin que sean muchos los que revelen importaciones en número significativo.

Ovoide 4 (figs. 15-19)

El tipo Ovoide 4 sigue siendo hoy por hoy uno de los que más problemas de definición ofrece $y$, de igual modo, uno de los que suscita más animada controversia.

La cronología de su difusión y sus características morfológicas, sin precedentes en la producción de la Ulterior interior, se entienden como un reflejo de los influjos itálicos en la manufactura alfarera del Valle, y por lo tanto relacionables con las de los contenedores itálicos que tradicionalmente se agrupan en el universo de las producciones ovoides (Fabião 2001; Almeida 2008: 100). Las bocas definidas por labios cortos y rectos con tendencia subtriangular o subrectangular, así como los cuellos cortos, asas cortas y con secciones ovales, son trazos morfológicos típicos de determinadas producciones itálicas, con sus mejores paralelos en tipos del Lacio, concretamente de la alfarería de Astura (Hesnard y otros 1989: 24-25, fig.6), de la Apulia (Cipriano y Carre 1989, fig.5; Toniolo 1991: 18, fig.7; Toniolo 1996; Toniolo 2000: 183) y brindisinos de Apani, en particular de la forma VII (Palazzo, 1989: 548-549 y fig.4) (fig. 15).

Por otra parte, sus afinidades morfológicas y su cercanía con el bien conocido tipo Haltern 70 contribuyen a que persista la incertidumbre de su aceptación como tipo bien individualizado desde fechas tardorrepublicanas (por lo menos mediados del siglo I a.C.). Dichas similitudes con la forma Haltern 70 fueron en un primer momento positivas, ya que permitieron reconocer la existencia de una "anomalía formal", con manifiestas diferencias respecto al tipo Haltern 70 canónico. No obstante, a posteriori resultaron tener un efecto contrario, ya que acabaron llevando a una escasa valorización y menor atención de dicha singularidad por parte de la investigación. Tal vez sea éste uno de los principales motivos para que el "recorrido tipológico" de esta forma haya acabado siendo bastante tortuoso.

Después de que D.P.S. Peacock y D. Williams individualizaran una morfología de ánfora similar a las Haltern 70, aunque de módulo menor, incluyéndola dentro de su Clase 15 bajo la rúbrica "unusually small variant" (Peacock \& Williams 1986: 115-116), C. Fabião, de nuevo basándose en otros ejemplares hallados en el campamento militar tardorrepublicano de Lomba 
do Canho (Arganil, Portugal), y que eran claramente integrables en esta "variante", propuso la separación morfológica defnitiva entre ambos formatos, manteniendo dentro de la Clase 15 a las Haltern 70 "aunténticas" y asignando la clasificación de Clase 15A a la "variante pequeña" de los conocidos contenedores béticos (Fabião 1989: 61-64). Junto a ello, confirmaba también la existencia de otra forma republicana, a la cual se debería aplicar la designación de Clase 24 de la clasificación de Peacock y Williams, puesto que se trataba del verdadero tipo precedente de los contenedores oleícolas béticos de época altoimperial (Fabião 1989: 73-74).

Algunos años después, la constatación por parte del mismo investigador de los recurrentes problemas en su identificación fragmentaria, el parecido formal con otros tipos o sub-tipos procedentes del Guadalquivir con cronología igualmente republicana, la gran variabilidad de atributos formales existentes y las frecuentes dificultades en delimitar las fronteras tipológicas entre esos subtipos, especialmente entre la Clase 15A y la Clase 24, llevó C. Fabião a reformular el estado del conocimiento existente en esos momentos y a plantear la posibilidad de que no se tratase de tipos diferentes, sino que representaran distintas caras de un universo formal cuya principal característica era su asumida diversidad. Por ello, propuso que se agruparan en la Clase 24 las dos variantes, la Clase 24 propiamente dicha y la anterior Clase 15A o Haltern 70 small variant (Fabião 2001: 667-669).

A partir de entonces, y en gran parte debido a ese trabajo, integrado en las Actas del Congreso Internacional Ex Baetica Amphorae, que alcanzó rápidamente una enorme repercusión, comenzó a denominarse como Clase 24 a un conjunto de contenedores republicanos, que presentaban detalles morfo-tecnológicos y un "aire de familia" común a todas las producciones republicana de la Ulterior. De este modo, la Clase 24 quedó marcada por una considerable heterogeneidad, por cuanto se incluían en ella bajo una misma denominación dos subgrupo de contenedores ovoides. El primero se caracterizaban por presentar bocas con collarín marcado y exvasado, en definitiva similares a los de las Haltern 70, pero que destacaban por su pequeño tamaño, su cuello corto y sus asas de reducido arco. El segundo incluía bocas definidas por labios menos exvasados y más engrosados, que se entendían como "más" afines a los tipos olearios, acercándose a la morfología de las llamadas Dressel 20 arcaicas, Dressel 20A de Berni (1998: 26-27 y fig. 4) u Oberaden $83^{16}$.

16. Una cuestión relativamente secundaria, casi colateral, pero igualmente significativa que aportó este trabajo fue la caracterización
Como alternativa a la genérica Clase $24^{17}$, intentándose evitar probables connotaciones o asociaciones directas con otras designaciones tipológicas con las cuales estas ánforas no tienen por qué mantener un relación directa, y por mantener la secuencia interna dentro de la "familia" de ánforas ovoides de la Ulterior (Almeida 2008), dentro del cual se individualizaron hasta 7 tipos, recientemente ampliados a 10 (García Vargas e.p.), se propuso adscribir los diferentes subgrupos a dos tipos diferentes. Por lo tanto, mientras que a los segundos, los pertenecientes a la anterior Clase 24, con bocas definidas por labios de sección "almendrada" o subcircular (afines a los de la posterior Dressel 20A u Oberaden 83), se atribuyó el tipo Ovoide 6, al subgrupo definido por las bocas que se pueden genéricamente clasificar como en collarín, que se corresponden con la anteriormente llamada Haltern 70 small variant, se atribuyó el tipo Ovoide 4, denominación con la que últimamente empiezan a aparecer estas ánforas en las publicaciones que incluyen materiales béticos de época republicana ${ }^{18}$.

En lo que concierne a los atributos puramente morfológicos que se consideran propios del tipo Ovoide 4, se encuentra una boca definida por un labio ligeramente exvasado y corto, con una altura comprendida entre los 3 y $4 \mathrm{~cm}$, con perfiles de tendencia triangular o rectangular, pudiendo presentar igualmente un ligero engrosamiento superior o la pared interna presentarse también ligeramente cóncava. La boca se presenta en forma de collarín marcado, bien diferenciado y destacándose claramente del cuello. A su vez, éste último es bitroncocónico y corto, con una longitud media de $10 \mathrm{~cm}, \mathrm{y}$ de él arrancan unas asas igualmente cortas pero con una apertura considerable, describiendo un radio abierto y un perfil cercano al semicírculo, algo que deriva directamente de la forma del cuello, al igual que sucede en otros tipos ovoides. Las asas poseen una marcada acanaladura central que las recorre longitudinalmente,

de todo el conjunto incluido en la Clase 24 como el ánfora olearia bética probablemente más antigua, con morfología claramente romana, remontando su origen a mediados del siglo I a.C., al menos.

17. Debe recordarse que, como se señala en la nota 14 , reservamos la denominación Clase 24 para las ánforas olearias republicanas de la Ulterior de procedencia incierta o de producción litoral, mientras que la misma forma producida en el valle del Guadalquivir será denominada por nosotros Ovoide 6.

18. De momento, carecemos de información acerca de la existencia de un grupo Haltern 70 small variant de producción costera, por lo que no se presenta un problema de denominación similar al que referimos para Ovoide 1 y Ovoide 6. En cualquier caso, ejemplares de formas próximas a Ovoide 4 de producción costera se han integrado aparentemente sin grandes problemas en el grupo de las Ovoides gaditanas o Dressel 10 arcaicas (Berni Millet 2011: 85-86). 
terminando en una profunda digitación realizada en la base con la pasta bastante fresca. El cuerpo es de forma aproximadamente cilíndrica, semejante al de la Haltern 70 , pero en la proporción inversa, es decir, con el diámetro máximo generalmente en su mitad superior sin estar normalmente muy marcado, en otras palabras, la premisa básica de una morfología ovoide.

Muchos de estos rasgos tecno-morfológicos, sobre los cuales ya se ha llamado la atención en varias y repetidas ocasiones (Fabião 1989; Fabião 2001; García Vargas 2001; Almeida 2008) resultan comunes a prácticamente todos los tipos del valle del Guadalquivir en la Republica tardía, de modo que, ante la ausencia de varios de los rasgos diagnósticos es, virtualmente imposible distinguir cuando no poseemos más que fragmentos de labio, como ya había advertido C.Fabião (1989: 63). Posteriormente, principalmente con base en el estudio de las piezas de Scallabis (Santarém), fue posible constatar que como regla general los bordes pertenecientes a este tipo no sobrepasaban los $4 \mathrm{~cm}$ de altura. No obstante, una antigüedad basada exclusivamente en el criterio de la altura del labio, aunque sea orientativa, no es taxativa, pues, como se puede constatar, existe una verdadera heterogeneidad morfológica a este nivel, que remonta ya a los ejemplares más antiguos (Almeida 2008: 102).

Resulta significativo verificar que, al contrario de la generalizada aceptación de idéntica o mayor antigüedad en los entornos productivos costeros, desde siempre existió cierto prejuicio a la hora de aceptar la misma antigüedad para las producciones de morfología romana en el interior de la Ulterior. Paradójicamente, y a pesar de la cercanía existente entre la Ovoide 4 y la Haltern 70 , todos los ejemplares completos reconocidos en varios naufragios a lo largo del siglo pasado, como Titan o Grand-Conglué 3, fueron sistemáticamente clasificados, hasta fechas bien recientes (Liou 2001), como indeterminadas o como Dressel 10.

Conviene de nuevo resaltar que el problema más importante acerca del origen, caracterización y evolución formal de los contenedores de la forma Ovoide $4 \mathrm{del}$ Guadalquivir resulta ser, tal como se ha referido, el de sus conexiones tipológicas con las Haltern 70 "verdaderas", si es que podemos hablar en estos términos. Según la lectura realizada hace poco por uno de nosotros, no estaba aún de todo claro si representan dos formas sucesivas, derivadas la una de la otra (Ovoide 4-Haltern 70), o si son dos tipos que surgen independientemente y conviven, hasta la desaparición del primero de ellos antes del cambio de era (Almeida 2008: 103-104), continuando la producción de las Haltern 70 hasta fines del siglo I d. C., o incluso más allá si se consideran como tales a las ánforas derivadas de ella como las denominadas Verulamium 1908 (Carreras Monfort y Marimon 2004: 32). La causa principal de duda al respecto residía en la supuesta existencia de una boca presuntamente clasificable como Haltern 70, mencionado por parte de A. Tchernia, que formaba parte del cargamento del barco romano hundido hacia 70-60 en la Madrague de Giens (Var) (Tchernia 1990: 296). Lo cierto es que esta pieza no ha sido jamás publicada de forma gráfica y no se conoce hasta la fecha ningún otro contexto, en el segundo tercio del siglo I a.C., con algún ejemplar que podamos considerar como típica Haltern 70. (Figs. 16, 17 y 18).

Lo que sí que podemos constatar actualmente es que los ejemplares más antiguos de Haltern 70 con los que a ciencia cierta se cuenta, provienen de contextos datados a partir del mediados del siglo I a.C., como el alfar de la calle Javier de Burgos en el Puerto de Santa María (Cádiz: García Vargas 1998; García Vargas 2001: 141, $\left.\mathrm{n}^{\circ} 6\right)$, donde fueron aparentemente fabricadas junto a ánforas púnicas de salazón del tipo 7.4.3.3.(Mañá C2b, antiguamente Dressel 18), ánforas ovoides gaditanas e imitaciones locales del tipo Dressel 1C. Por lo tanto, tal y como ya se ha comentado en otro momento (Almeida 2008: 100-104), se torna difícil aceptar la existencia de la producción de Haltern 70 "típicas" en el espacio de tiempo comprendido en el $2^{\circ}$ cuarto del siglo I a.C., y consecuentemente habría que considerar la posibilidad de que haya un error en la clasificación del ejemplar recuperado en la Madrague de Giens, o, en alternativa, considerar que el ánfora documentada en ese naufragio se corresponda en realidad con algún otro tipo ovoide republicano extra-provincial, tal como también hicieron notar R. Étienne y F. Mayet (2000: 90), seguramente de Ovoide 4.

La documentación arqueológica actualmente existente certifica que en los contextos de mayor antigüedad, con fechas próximas a la del pecio de La Madrague de Giens y en las dos décadas posteriores, únicamente se documentan ánforas de morfología ovoide, en este caso del tipo Ovoide 4, tales como las conocidas en varios naufragios del Mediterráneo, y siempre con carácter minoritario, como es el caso de la carga de los pecios de Grand-Conglué 3 (Liou 2001), Titan (Benoit 1956), Portopí (Cerdá I Juan 2000), Cap Gros "C" (Gauthier y Joncheray 1993), Cala Bona I o Illes Formigues I, de donde procede el propio ejemplar del Museo Marítimo de Barcelona publicado por Peacock y Williams em 1986 (Martín Menéndez 2008). En contextos terrestres nos las encontramos entre el material del 


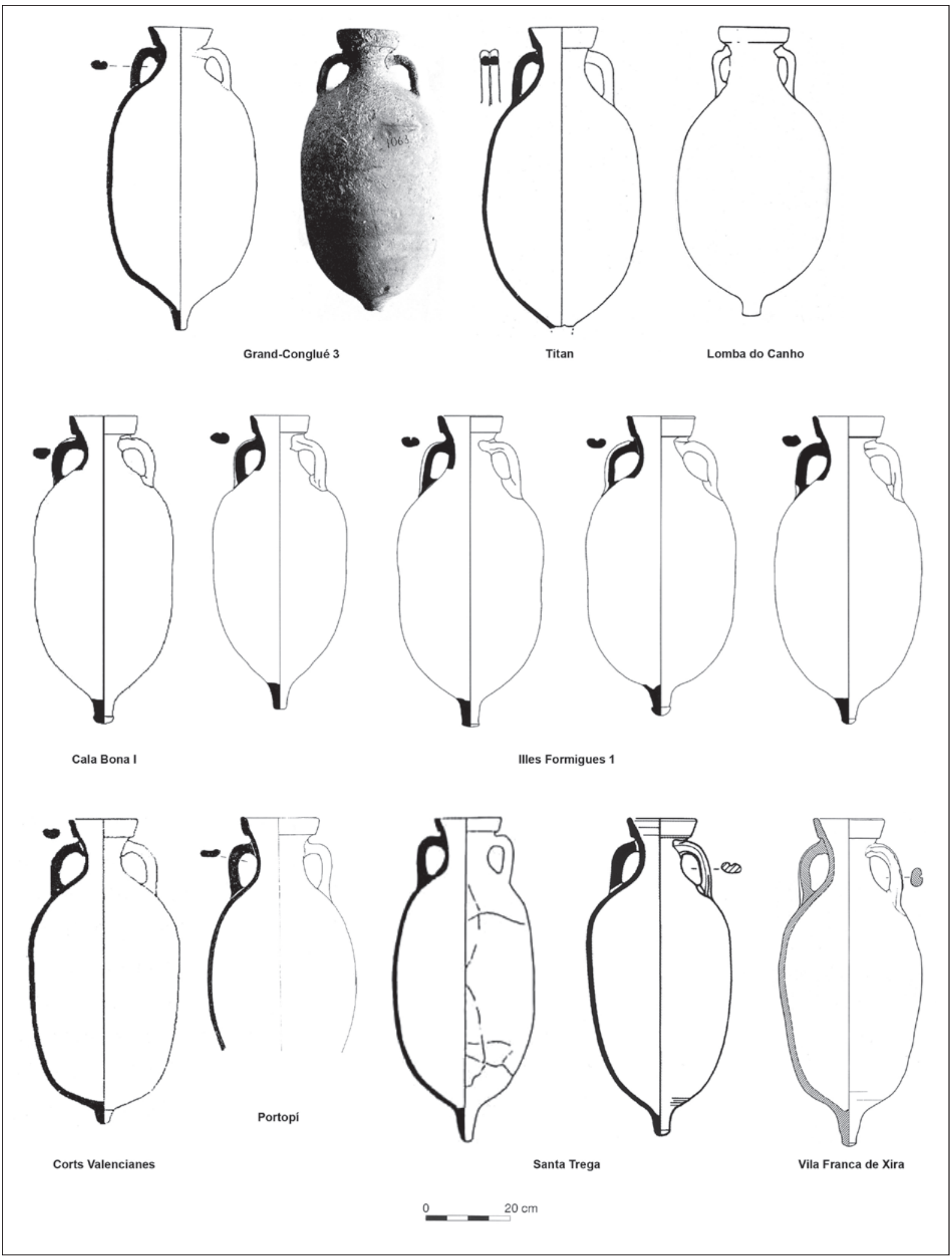

Figura 16. Ánforas del tipo Ovoide 4. 


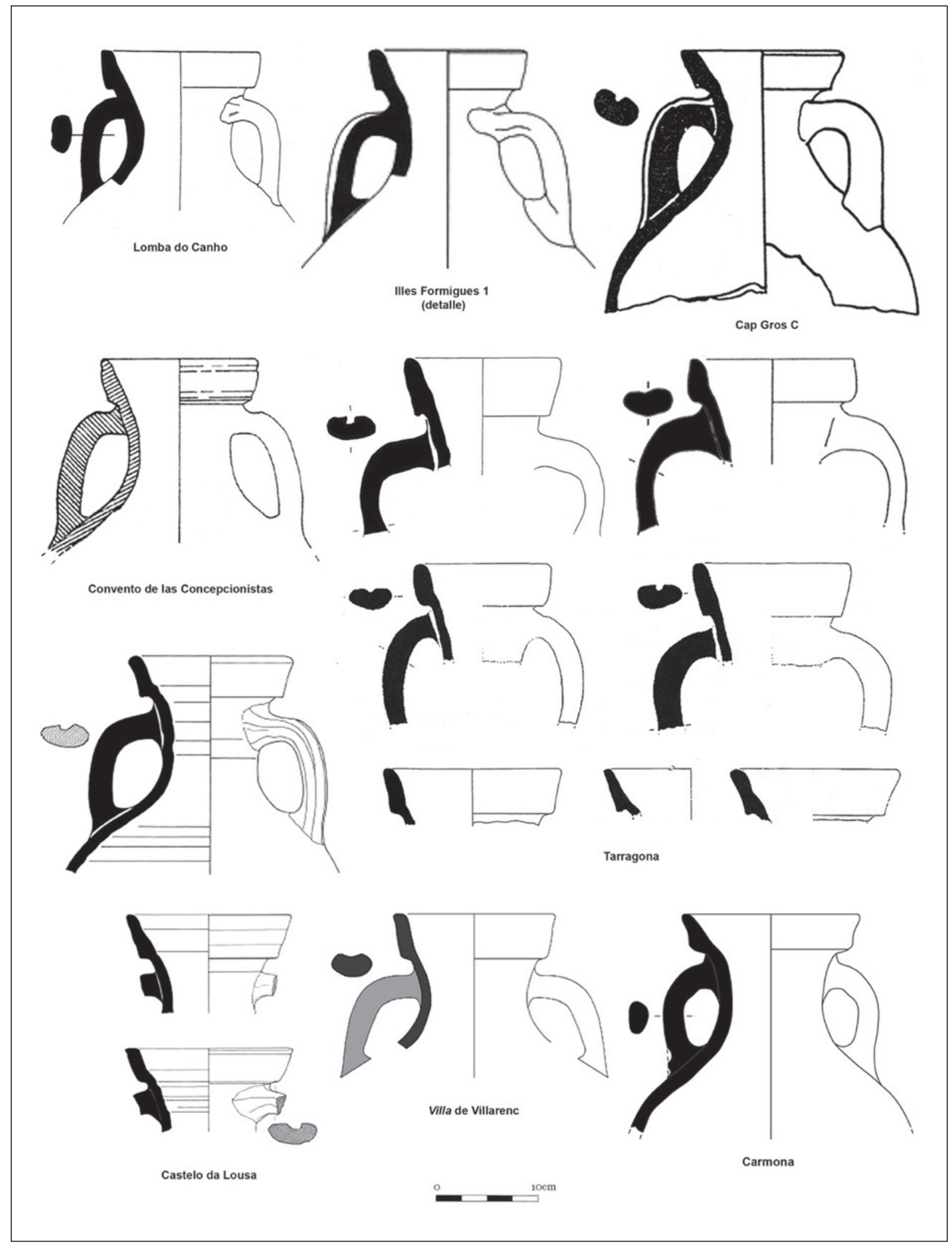

Figura 17. Ejemplares fragmentarios de ánforas del tipo Ovoide 4. 


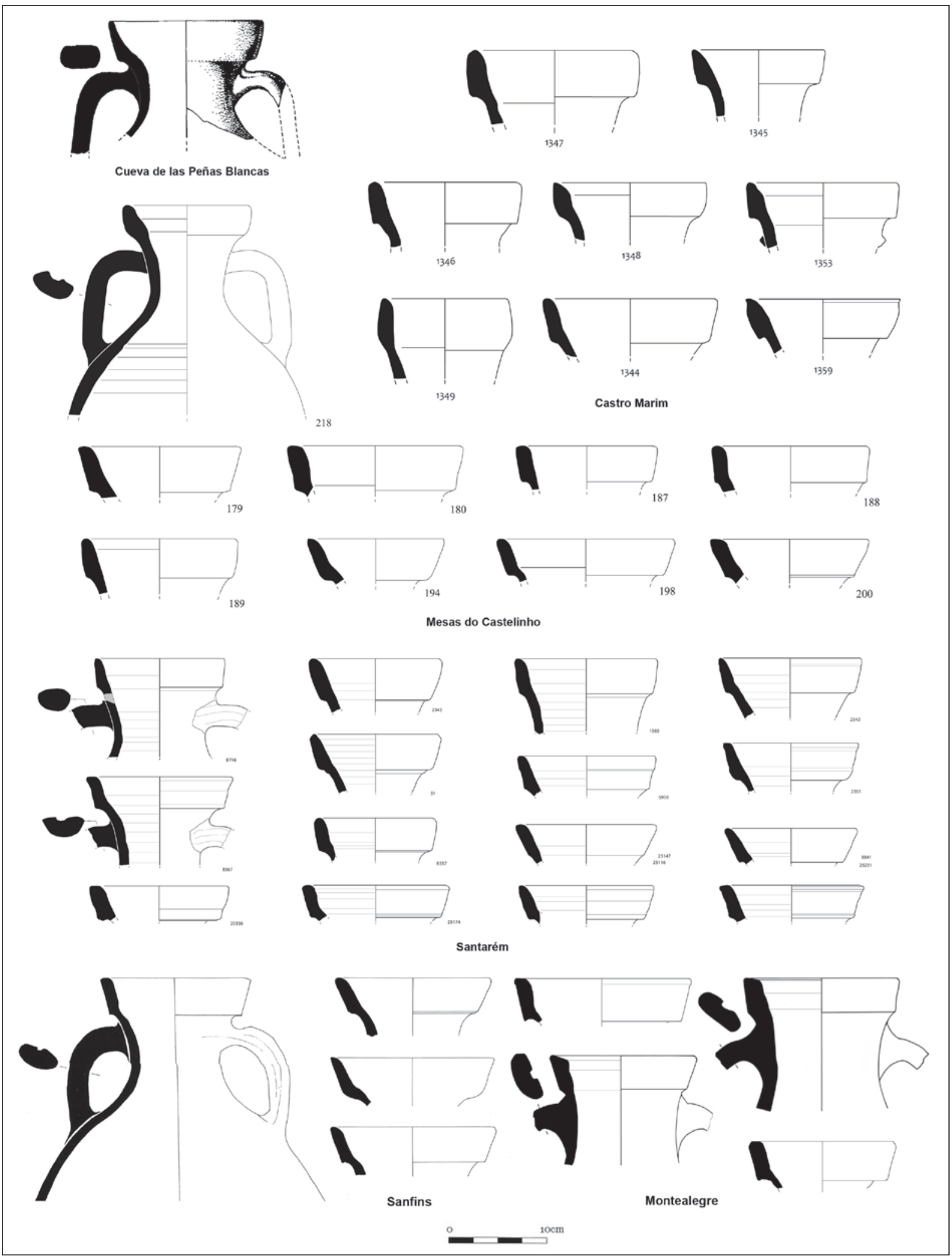

Figura 18. Ejemplares fragmentarios de ánforas del tipo Ovoide 4. 


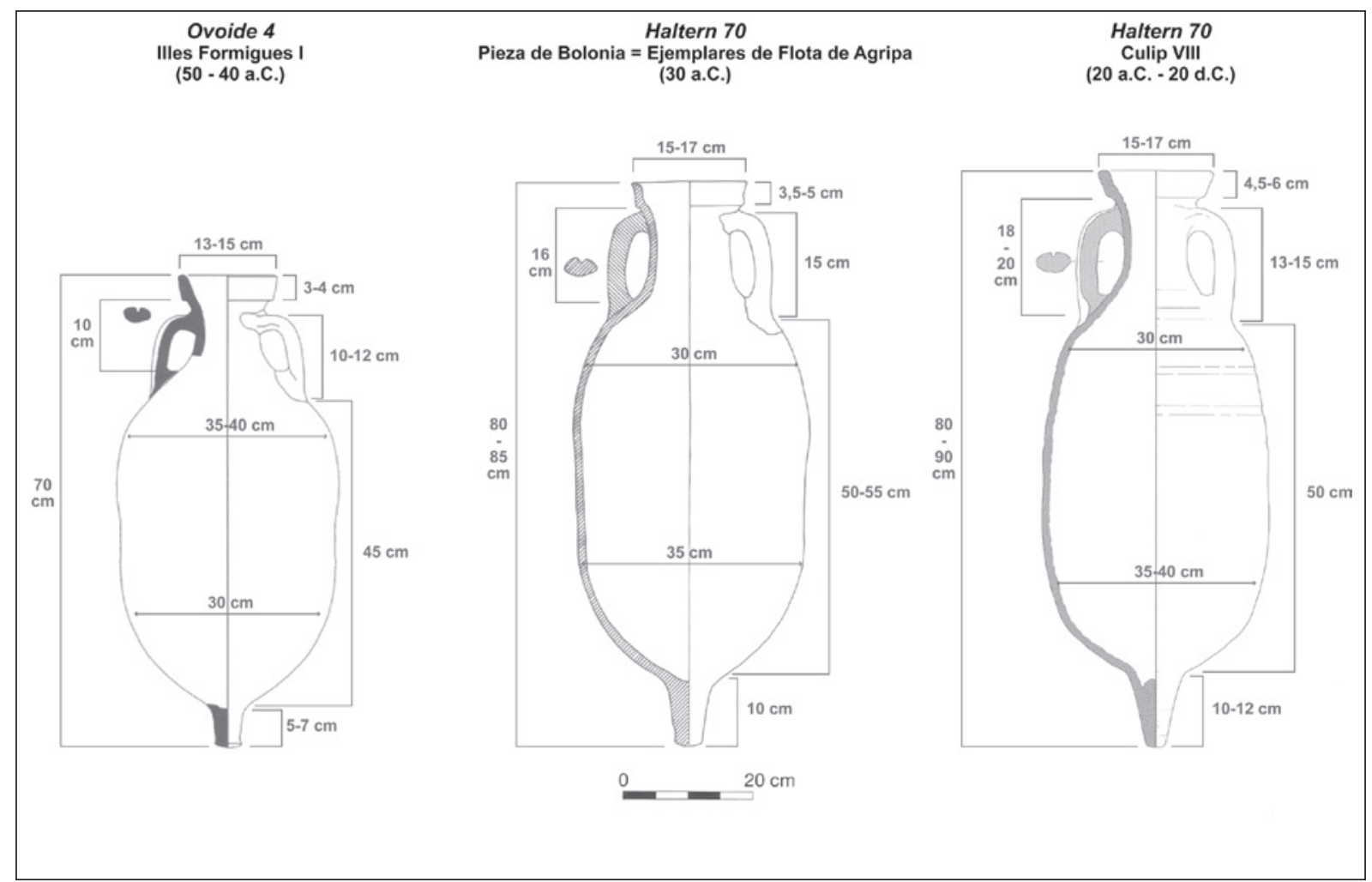

Figura 19. Esquema comparativo entre ánforas de tipo Ovoide 4 y Haltern 70 del período augusteo inicial.

horizonte 1 del denominado santuario de Cibeles (Lemaître, Desbat y Maza 1998), en el cardo D de Ampurias (Aquilué y otros 2004: 113 y fig.68.6), en el campamento de Lomba do Canho (Fabião, 1989), Scallabis (Santarém) (Almeida 2008: 100-104), Mesas do Castelinho (Parreira 2009), Castro Marim (Viegas 2011), Cueva de las Peñas Blancas (Lillo Carpio 1986: 125) o Corts Valencianes, Valencia (Pascual Berlanga y Ribera i Lacomba, 2001), si bien en algunos de estos lugares las cronologías son menos finas.

Basándonos en lo hasta ahora expuesto, pensamos que el final de la vida de este tipo anfórico coincide y se solapa parcialmente con el de inicio de la Haltern 70. Nos parece evidente que, en este caso concreto y a pesar de su posible filiación, el surgimiento de un segundo tipo no supone la desaparición inmediata de otro anterior, constatándose la continuidad de producciones que, a falta de mejor término, se pueden definir como "arcaizantes" hasta momentos relativamente lejanos de su fecha de aparición, y que conviven con los tipos dominantes en un nuevo periodo. Así mismo, entendemos como bastante probable que en el lapsus de tiempo correspondiente a lo que puede ser la etapa terminal de la Ovoide 4, e incluso de otros tipos ovoides, comprendido de una forma genérica entre 30-20 a.C., habrían seguramente coincidido con las primeras variantes de Haltern 70, muchas de ellas con trazos morfológicos aún poco claros, fruto de una fase inicial de experimentación, que dificultan de sobremanera una correcta apreciación de los momentos y morfologías de lo que creemos que sería el paso de un tipo a otro. Por lo tanto, en términos de evidencia material, las Ovoide 4 se constatan aún en contextos de los años 30-10 a.C., como Corts Valencianes, en Valencia, con ciertas conexiones con las Haltern 70 iniciales (Pascual Berlanga y Ribera i Lacomba 2001: 576; Ribera i Lacomba 2010), o de los años 20-1 a.C., como el alfar de la calle González Parejo no 19B de Carmona, donde, no obstante, pueden ser residuales (García Vargas e.p.).

Es justamente en un momento tan temprano como principios del último tercio del siglo I a.C., cuando aparentemente se produce la "cristalización" formal y el inicio del empuje comercial de las Haltern 70 del Guadalquivir como tipo bien diferenciado de la Ovoide 4. Las figuras 17-19 que se presentan aquí, y las 27-28 que se presentan infra en el apartado de las Haltern 70 
(según la fig. 29 de Almeida 2008: 103; revisada y ampliada), son esclarecedoras respecto de las diferencias morfológicas entre las Ovoide 4 y las "Haltern 70 iniciales". Entendemos, por lo tanto, que las Ovoide 4 son anteriores a las Haltern 70, que éstas últimas proceden probablemente de aquellas a partir de formas intermedias, tendiendo a imponerse sobre las primeras en los mercados atlántico-mediterráneos a partir de los dos últimos decenios del siglo I a.C., época que vería la desaparición definitiva de las Ovoide 4 del Guadalquivir. (Fig. 19).

Nuestra propuesta de trabajo al respecto de la dicotomía del complejo "Ovoide 4-Haltern 70" del Guadalquivir es, por tanto, la siguiente (cf. fig. 19):

- Ánforas de morfología antigua, Ovoides 4, tout court, con inicios hacia 70 a.C. y desapareciendo hacia el 20-10 a.C.

- Ánforas Haltern 70 iniciales, observables hacia 30 a.C, conviviendo con las anteriores.

- Ánforas Haltern 70 plenamente formadas (o "clásicas") documentadas a partir de c. 20 a.C.

La morfología del contenedor no parece ser el único punto de afinidad entre ambos tipos, pudiendo también ser el contenido. Esto al menos es lo que se puede deducir de los ejemplares del pecio de Illes Formigues 1, puesto que todos se encontraban resinados en su interior (Martín Menéndez 2008: 106-107), lo que no parece apropiado para un contenedor oleario. Por lo tanto, con base en esta evidencia, se puede apuntar el vino o un derivado del vino como un probable contenido. No obstante, la ausencia de más datos concluyentes no excluyen la posibilidad de que se trate de un envase multiusos.

En lo que concierne a la geografía de su distribución, se pueden observar tres grandes ejes, geográfica, política y económicamente distintos. Analizando desde el origen, en un primer nivel de mercado que podemos definir como de inmediato, se pueden encontrar varios contextos con el tipo en cuestión, tanto en las actuales Sevilla y Carmona (García Vargas e.p.), como en yacimientos con cronologías de mediados y de la segunda mitad del siglo I a.C., dedicados principalmente a actividades mineras o alfareras, centrados esencialmente en las provincias de Córdoba y Cádiz. Tal es el caso de las minas y escoriales de Ermita de San Sebastián, El Piconcillo y Calamón (Domergue 1987), todas en la provincia de Córdoba ${ }^{19}$, o por ejemplo las documenta-

19. Las tres estaban fechadas en entre la segunda mitad del siglo I a.C. y inicios del I a través de un elemento común, las Dressel 7-11. En todas ellas los conjuntos cerámicos se componen sobre todo por das en los alfares de la Calle Troilo (Niveau de Villedary y Blanco Jiménez 2007: 216; fig. 10.1-2) o de Rabatún, en Jerez de la Frontera (García Vargas y López Rosendo 2008: 295; fig. 10.4).

Una segunda región de mercado es el Occidente peninsular, particularmente los escenarios relacionados con el proceso de conquista tardío (Almeida 2008; Almeida 2010), pudiendo documentarse casi de manera sistemática en todos los yacimientos con ocupación clara atribuible a la segunda mitad del siglo I a.C., con clara connotación militar, o militarizados, es decir, donde de algún modo se han instalado militares. Estos representan un abanico más amplio, incluyendo sitios militares propiamente dichos como Santarém o Lomba do Canho, pero también oppida más antiguos con presencia de efectivos in situ o en las cercanias, como pueden ser Mesas do Castelinho o Castro Marim y varios de los castros del Norte de Portugal y de la actual Galicia. Por último, aún relacionados con la clase de yacimientos "militarizados", el tipo Ovoide 4 está siempre presente en los castella o establecimientos similares, sea en la cuenca del Guadiana (por ejemplo el Castelo da Lousa), en la zona circundante a Ebora (los recintos ciclópeos y los fortines del actual Alentejo Central: Mataloto 2008), o aún en los metalla del suroeste ubicados en la cuenca del Odiel ${ }^{20}$ (Peréz Macias y Delgado Domínguez 2007).

La tercera zona sería la mitad oriental de la Península. En esta gran región se verifica su presencia en yacimientos de idéntica naturaleza, con menor representación en sitios militares o "militarizados" como Pozo Sevilla (Morin de Pablos y otros 2010), pero en contrapartida con mayor número de ejemplos en los oppida romanizados, especialmente en el sureste (Molina Vidal 1997) y en los núcleos urbanos como Tarragona (Ruiz de Arbulo, y otros 2010; Gebellí Borras y Díaz 2001; Díaz García y Otiña Hermoso 2003) o en algunos rurales como El Vilarenc (Revilla Calvo 2010).

Por último, pecios como los de Illes Formigues 1, Cala Bona 1, Titán o Grand-Conglué 3 certifican de forma incuestionable la circulación de estos contenedores hacia mercados extra-peninsulares, configurándose la Galia meridional y sus principales ejes de

Dressel 1 de procedencia itálica y algunas piezas clasificadas como Dressel 7-11, que parecen documentar casos claros de Ovoide 4. Por lo tanto, deben retrasarse las referidas cronologías basadas en la presencia de los tipos salazoneros.

20. En Cerro del Moro (Nerva, Huelva), creemos que algunos de los fragmentos clasificados como Haltern 70 en realidad se corresponden con Ovoide 4 (Peréz Macias y Delgado Domínguez 2007: 153; fig. 6.1,3,4 y 6). 
penetración fluviales un mercado civil emergente ya en el tercer cuarto del siglo I a.C., tal como parece entreverse en el horizonte 1 del santuario de Cybèle en Lyon (Lemaître, Desbat y Maza 1998: 55).

\section{Ovoide 5 (figs 20-21)}

Las ánforas del tipo Ovoide 5, propuestas como tal por primera vez por uno de nosotros (Almeida 2008: 126-134) e incluidas desde entonces en los repertorios regionales (Almeida 2010; García Vargas e.p.), representan en cierta medida un caso similar al de las Ovoide 4 (supra) por cuanto ha sido, y es, habitual clasificarlas como pertenecientes a otras formas con las que, no obstante, creemos que no deben ser confundidas. En el caso de las Ovoide 5, se las suele asignar al tipo Ovoide 1 (Clase 67/LC 67) sobre la base de un rasgo común que, por lo demás, no es exclusivo de estos contenedores: la moldura o anillo medial que presentan en el cuello. Resulta evidente que rasgos morfológicos del borde, del propio cuello, de la inserción de éste en los hombros o del cuerpo de las Ovoide 5 son tan peculiares $y$, en general, definen un recipiente de tan acusada "personalidad" que no conviene que quede "oculto" o "sumido" en el interior de otras morfologías, máxime cuando estas características formales son ya las propias del tipo desde el momento de su aparición, sin que parezca que éste deba nada desde el punto de vista morfológico a las Ovoide 1 (Clase 67/LC 67).

Para comenzar, los bordes de las Ovoide 5 son siempre claramente diferenciables de los que corresponden a las Ovoide 1; mientras los de éstas últimas son redondeados o almendrados en la inmensa mayoría de casos, aunque existen ciertos ejemplares con borde de tendencia subrectangular, los de las ánforas del tipo Ovoide 5 son subtriangulares o, menos frecuentemente, subrectangulares, comúnmente rectos y con un labio colgante hacia el exterior "asumiendo casi la forma de un pequeño faldón” (Almeida 2008: 126). Los cuellos, y esto parece especialmente frecuente en los ejemplares de Ovoide 5, tienen una marcada tendencia cilíndrica, por lo que su inserción en los hombros del recipiente marca una violenta ruptura de curva, como si hubiesen sido insertados en el cuerpo "a presión", característica que sólo volveremos a encontrar en las Ovoide 9 y en algunos ejemplares de variantes tempranas de Haltern 70 (tipo Flota de Agrippa, infra). Las asas, casi siempre con sección sub-circular, con surco dorsal poco pronunciado, y una marcada depresión en la base que parece provocada por la presión del dedo del alfarero en un claro intento de asegurar su adhesión al cuerpo, son muy cortas y horizontales, dada la escasa longitud del cuello, la amplitud de los hombros y la "violenta" inserción del primero en el segundo.

Los ejemplares completos de los pecios de Illes Formigues I y Cala Bona I (Martín Menéndez 2008) muestran un cuerpo de perfil apuntado con hombros anchos y rematado en un pequeño pivote macizo, morfología que recuerda con carácter general a la de las mal definidas Dressel 25, cuya producción se duda en atribuir al Egeo o al sur de Italia y, sobre todo, a las ánforas del tipo IV de Apani (Palazzo 1988: tav. XXIX.3) o $\mathrm{n}^{\circ}$ 2 del pecio Cap Gros “C”' (Gauthier y Joncheray 1993: 178), suponiendo que este último ejemplar sea una producción brindisina.

No hay casi que recordar que estas producciones no pueden ya confundirse, ni ante pequeños fragmentos de borde, con las Dressel 12, por más que algunos ejemplares republicanos afines a éste último tipo que, para simplificar, llamaremos Dressel 12 arcaica, presenten también un anillo en la base del borde. Por una parte, esta moldura se encuentra un tanto más arriba en las Dressel 12 arcaicas y, por otra, los bordes de estas últimas son de perfil redondeado u ovalado, muy lejos del aspecto macizo de los bordes de la Ovoide 5; finalmente, las pastas cerámicas de las Dressel 12 arcaicas no corresponden, en lo que se conoce, con la de las del bajo Guadalquivir, sino más bien con las de la costa del Estrecho, mientras que la mayoría de las Ovoide 5 presentan pastas propias del valle de este río. Decimos la mayoría, porque es posible que pueda separarse algún día una serie costera de Ovoide 5 producida en los alfares de la costa mediterránea. Es lo que se deduce de los contextos del Cerro del Mar (Torre del Mar, Málaga), tanto los publicados por O. Arteaga (1985) como los procedentes de la campaña del Deutsches Archälogisches Institut (y dirigidas por el propio Arteaga) en 1998 que permanecen inéditos. En ambos casos, se asocian a Dressel 1C, LC 67 y 7.4.3.3. (en un contexto general en el que están presentes las campanienses B: Lamb. 1, 2) y presentan pastas peculiares que pueden corresponder a producciones locales. La asociación a LC67 en los mismos contextos parece demostrar una cierta independencia tipológica entre un tipo y otro, independientemente de su lugar concreto de producción, si bien las producciones del Guadalquivir parecen haber sido, si es que existen verdaderamente otras, ampliamente mayoritarias.

La escasa "visibilidad" arqueológica, hasta el día de hoy, de las Ovoide 5 (vid. ad.es. García Vargas y Bernal Casasola 2008) les confiere, como sucedió en 
su día a las Ovoide 4, un engañoso carácter de "contenedor minoritario". Sin embargo, una vez efectuada la necesaria separación de los ejemplares de Ovoide 1 y Ovoide 5 (vide Bernal Casasola 2007: 349 para una demanda clara en este sentido) queda en evidencia que el área de distribución de ambos tipos es coincidente y que el número de ejemplares, completos o fragmentarios, de las ánforas cuya atribución hacemos ahora a Ovoide 5, sin ser de momento tan alto como el correspondiente a Ovoide 1 (LC 67), está lejos de representar a un tipo de carácter "minoritario", dentro de los parámetros cuantitativos que caracterizan a las ánforas de la Ulterior republicana.

De las recientes excavaciones en el Patio de banderas del Alcázar de Sevilla proceden una serie de ejemplares fragmentarios (fig. 21) del tipo hallados en contextos que se relacionan con la construcción del edificio de africanum, una edificación cuya cronología inicial ha sido establecida entre 50 y 25 a.C. En estos contextos son incluso más abundantes que las Ovoide 4 y Ovoide 1 , lo que, aunque puede ser fortuito, también puede considerarse una muestra de que no se trata de producciones menores en número. Un ejemplar procedente de la UE 1921 (García Vargas e.p.:), carente de asas, resulta canónico de la forma Ovoide 5 y conserva la totalidad del borde y el cuello completo con su anillo medial; muy similar es el cuello, también sin asas, de la UE 1915 (García Vargas) que procede, no obstante, de un contexto tardoantiguo que alteró profundamente las unidades republicanas. Fragmentos de los típicos bordes de Ovoide 5, aunque sin conservar el cuello y el anillo del mismo, se documentan en otras unidades, como 1920 (García Vargas e.p.), relacionada igualmente con la construcción del edificio de opus africanum en el tercer cuarto del siglo I a.C. Esta parece ser la fecha de máxima difusión de la forma también en el área del bajo Guadalquivir, donde debieron encontrarse los talleres productores y donde no se constata por ahora su perduración en época augustea.

Ejemplares virtualmente idénticos a éstos del $\mathrm{Pa}$ tio de Banderas de Sevilla se documentan en Scallabis (Santarém), donde las piezas que están en "su contexto", es decir, no son residuales, se fechan entre $50 \mathrm{y}$ 25 a.C. (Almeida 2008: 134), fase 1B/1C de la Alcáçova de Santarém, en un contexto cerámico similar al de Sevilla, que incluía Ovoide 1 (LC 67). En Mesas do Castelinho (Almodôvar, Portugal) se documentan bordes de la forma en contextos que se fechan desde mediados del siglo I a.C. a mediados del I d. C., siendo evidente que al menos estos últimos son ya residuales (Parreira 2009: 72). Aquí se le denomina ánforas Castelinho 1
(Parreira 2009: 66) y, aunque es interesante en este caso la individualización del tipo, que no es confundido con ninguna otra forma bética, resulta excesivo darle una nueva denominación derivada de un yacimiento en el que, además, no fue producido, debiéndose clasificar en nuestra opinión estos fragmentos, al menos los que se tenga seguridad de que proceden del Guadalquivir, bajo la etiqueta general de Ovoide 5. Uno de los cuellos más completos de Ovoide 5 de Mesas do Castelinho ya fue publicado por C. Fabião (2001: 682, fig. 1.2) en el artículo que inauguraba "con proyección internacional" los estudios de tipología de ánforas republicanas del Guadalquivir y del que los trabajos posteriores, incluido éste, son como ecos inversos (de voz aumentada). En aquel caso, se incluían aún entre las LC 67 lo que, andando el tiempo, ha constituido, como se ha dicho, un nuevo tipo por derecho propio.

Otro tercio superior de Ovoide 5 procedente de Mesas do Castelinho estaba hasta ahora inédito y aunque en el trabajo que lo hace público (Parreira 2009: Est. XXIV, $n^{\circ} 229$ ) se da como de pasta costera del tipo 2, es probable que se trate de una producción de pasta verdosa similar a las de las cerámicas comunes regionales del bajo Guadalquivir, que es la más frecuente en los ejemplares de esta forma, pudiendo confundirse a simple vista con algunas pastas gaditanas, de las que es posible distinguirla mediante un estudio un poco más detallado. En la misma dirección apunta la morfología del asa, de sección subredondeada y con una leve depresión dorsal más que un verdadero surco, lo que es frecuente en las producciones de Ovoide 5 del Guadalquivir.

Una solución similar del asa (y del borde con labio en "faldón") presenta el ejemplar completo de Ovoide 5 del pecio de Illes Formigues I (Martín Menéndez 2008: 108) fechado hacia mediados del siglo I a.C., donde se documenta junto a Ovoide 4 del Guadalquivir, Ovoides gaditanas y Ovoides tarraconenes. Algo más profundo es el surco del ejemplar ilustrado del naufragio Cala Bona I (Martín Menéndez 2008: 116), con la misma solución del borde (junto a Ovoides gaditanas y Ovoide 4) y el del tercio superior de la Colonia San Jordi (Guerrero Ayuso, 1987: 161 y fig. 16.

Un fragmento descontextualizado y clasificado como Dressel 12(Viegas 2009: Est 104, $\mathrm{n}^{\mathrm{o}}$ 1332) de Castro Marim (fig. 21) presenta el arranque de las paredes del cuello ligeramente convergente, lo que parece una morfología alternativa a la ¿mayoritaria? de rígidos cuellos cilíndricos que hemos visto hasta el momento y a la que corresponden los ejemplares de los pecios, incluyendo el completo "pescado" en aguas de 
LOS TIPOS ANFÓRICOS DEL GUADALQUIVIR EN EL MARCO DE LOS ENVASES HISPANOS DEL SIGLO I A.C...

227

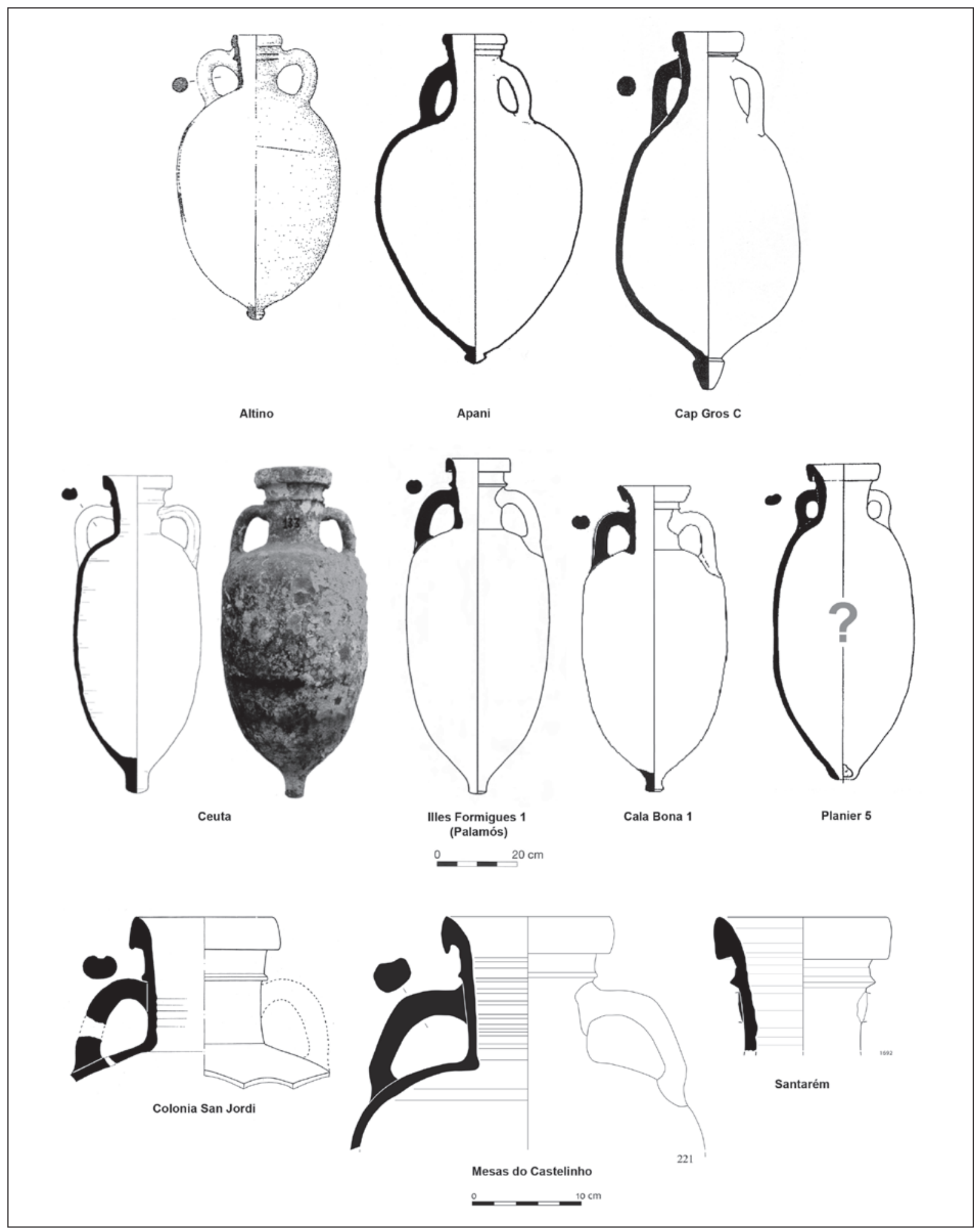

Figura 20. Tipos sur-itálicos/adriáticos comparativos: ¿Dressel 25? (arriba izquierda), Apani IV (arriba centro), brindisino indeterminado (arriba derecha) y ejemplares del tipo Ovoide 5 (abajo).

ISSN: 1133-4525 ISSN-e: 2255-3924

SPAL 20 (2011): 185-283

http://dx.doi.org/10.12795/spal.2011.i20.12 
Ceuta (Bernal Casasola 2007). Cuellos de paredes ligeramente convergentes también se documentan en: Santarém (Almeida 2008: 128, fig. 50, nº 3943); Lixus, clasificados sistemáticamente como LC 67 (=Sala 1) (Izquierdo Peraile y otros 2001: fig. 3: 1033-780 y $1033-$ 958; Bonet Rosado y otros 2005: 2022-1344 y 20221370), todos ellos del período mauritano medio (80/50 a.C.-15 d.C.); en el SE hispano (Molina Vidal 1995: 424, Lámina II, $\mathrm{n}^{\circ}$ 16-17); tal vez en Baelo Claudia (Domergue 1973: 48, fig. 14, $\mathrm{n}^{\circ}$ 1811); en el Patio de Banderas del Real Alcázar de Sevilla.

La distribución de las Ovoide 5 es similar a la que conocemos para otras producciones del Guadalquivir con "exito" en los mercados: costa atlántica de Marruecos, costa atlántica de la Península Ibérica y proyección hacia los mercados mediterráneos, con presencia en contextos submarinos de "redistribución" de la costa del NE peninsular y terrestres de las islas Baleares-Colonia Sant Jordi, en Mallorca (Guerrero Ayuso, 1987), siendo este último un ejemplar, descontextualizado y "canónico" desde el punto de vista de la forma del borde y del cuello, robusto y cilíndrico $-\mathrm{y}$ probable ejemplar de borde de Dangstetten (Ehmig 2010: Tafel 15, 449-058-1) testimonia su exportación, aparentemente a reducida escala y ya del momento "terminal" del tipo, hasta los "mercados" militares del limes germánico.

Por su parte, la Ovoide 5 guarda un lejano parentesco con las ánforas del tipo III de Brindisi (Palazzo 1988: tav. XXIX.3) y IV de Apani (Palazzo 1989: 548-549; Fig. 1.4), un contenedor de cuerpo más panzudo, pero con asas de perfil (que no sección) "deprimida" similares a las de la Ovoide 5 y que, como en esta, arrancan desde debajo de la moldura del cuello y ruptura de línea violenta entre el cuello cilíndrico y los amplios hombros. No puede decirse, sin embargo, que proceda de esta última directamente, porque en el mundo de las ánforas ovoides del Guadalquivir no se observan apenas derivaciones directas de formas adriáticas, excepto quizás en el caso de las Ovoide 4 y 6 y las escasas hasta ahora Lamboglia 2 imitadas o en ésta inspiradas (fig. 20).

\section{Ovoide 6 (figs. 22-24)}

Es bien conocido, que la producción de aceite de oliva en el valle del Guadalquivir alcanzó proporciones astronómicas durante la Antigüedad, convirtiéndose en una de las principales regiones exportadoras durante todo el periodo romano (infra). Ahora bien, a lo largo del siglo II y los momentos iniciales del I a.C., a tenor tanto de lo que nos presentan las fuentes escritas, como de la documentación arqueológica con la que contamos, hay que aceptar que una parte del suministro de los ejércitos, minas y ciudades hispanas, se efectuaría desde territorios extrapeninsulares, principalmente desde las distintas regiones itálicas.

Al ingente número de Dressel 1 fabricadas en la vertiente tirrénica, que suceden a las ánforas grecoitálicas en yacimientos hispanos de finales del siglo II y durante el I a.C., hay que sumarle el aporte de las producciones de la costa adriática, materializada principalmente por la presencia de contenedores vinarios de la forma Lamboglia 2 y de una buena representación de los distintos tipos de ánforas brindisinas, la mayor parte de los cuales parecen haber sido contenedores olearios (Palazzo 1989).

Como ya ha sido mencionado para otros tipos ovoides (ver supra), creemos que está fuera de toda duda la influencia que estas producciones de la vertiente adriática jugaron en el desarrollo de los tipos hispanos tardorrepublicanos, y en mayor medida en los del Guadalquivir, y tal vez sea en los envases olearios donde con mayor claridad se plasme. La mejor muestra de ello la tenemos en el tipo que, siguiendo a Peacock y Williams (1986), C. Fabião denominó como Clase 24 dentro del material estudiado en Lomba do Canho (1989: 73-74).

Si bien en un primer momento Peacock y Williams incluyeron dentro de su Clase 24 a todos los contenedores olearios anteriores a la aparición de las Dressel 20, pensamos, tal y como se viene defendiendo (Fabião 1989: 73-74; Almeida 2008: 145-147), que las ánforas olearias de época augustea, a pesar de tener características comunes con sus antecesoras, han de ser tratadas como tipos aparte. Siguiendo la propia publicación de Scallabis, creemos que lo más correcto es denominar a estas piezas como Ovoide 6 y asociarlas a la primera denominación que $\mathrm{C}$. Fabião le dio a los tipos olearios presentes en la Lomba do Canho, es decir, a una Clase 24 en la que no se incluyan las variedades de los últimos dos decenios del siglo I a.C. ${ }^{21}$

A pesar de la diversidad formal, que nos lleva a poner múltiples matices a nuestra descripción, pueden intuirse ciertas características formales del tipo Ovoide 6. De este modo, suele caracterizarse por un cuerpo generalmente ovoide y ancho -similar al que tendrán sus

21. Al igual que en el caso de otras producciones ovoides, estas ánforas olearias también fueron producidas en el área costera del sur peninsular. A pesar de tratarse de una misma tipología, creemos conveniente denominar a las producciones del Guadalquivir como Ovoide 6 u Ovoide 6/Clase 24 y a aquéllas del ámbito costero únicamente Clase 24, ya que no son, propiamente dicho, parte de la familia de ánforas ovoides el Guadalquivir. 
LOS TIPOS ANFÓRICOS DEL GUADALQUIVIR EN EL MARCO DE LOS ENVASES HISPANOS DEL SIGLO I A.C...

229

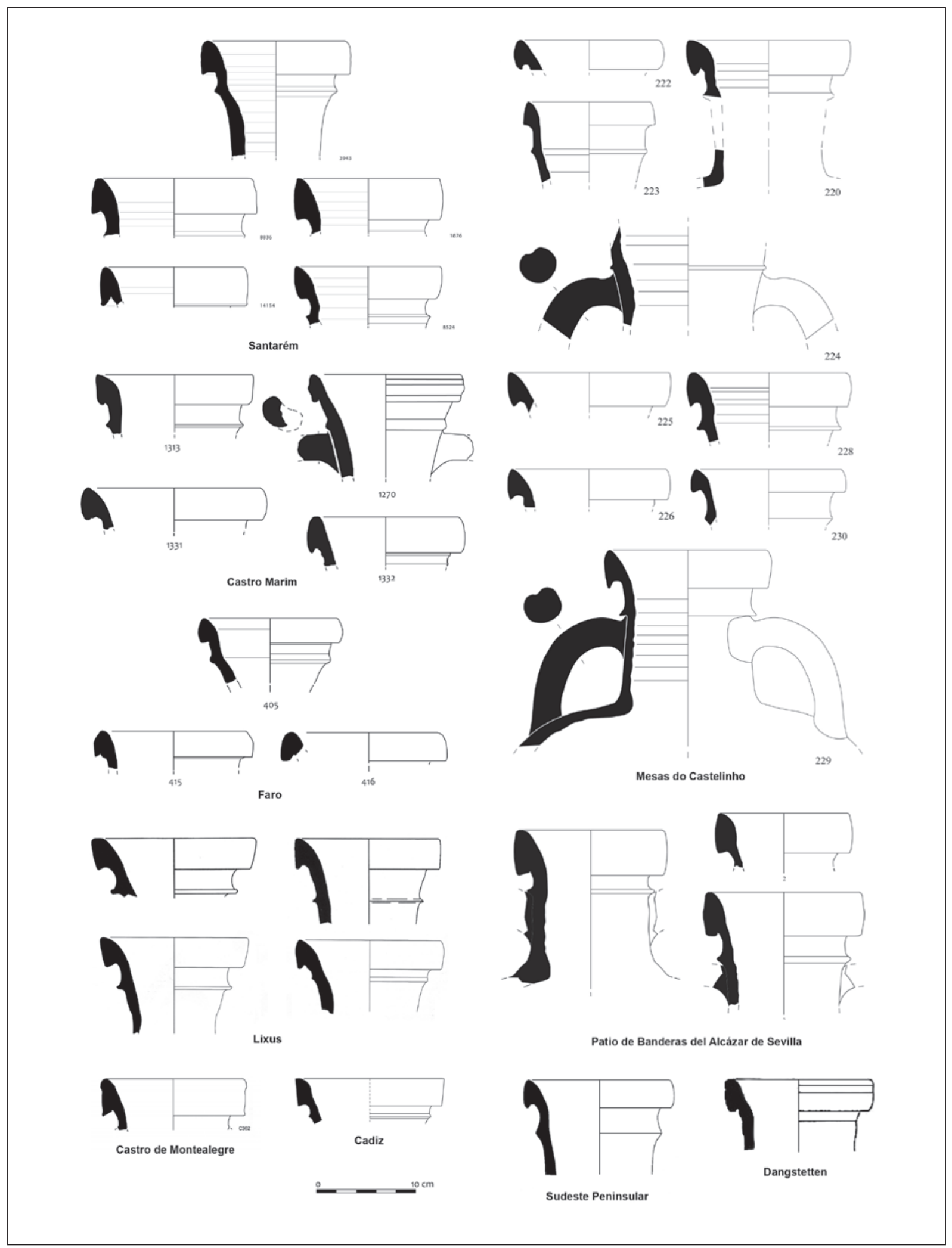

Figura 21. Ejemplares fragmentarios atribuibles al tipo Ovoide 5.

ISSN: 1133-4525 ISSN-e: 2255-3924

SPAL 20 (2011): 185-283

http://dx.doi.org/10.12795/spal.2011.i20.12 
sucesoras las Oberaden 83 (infra)- con las paredes redondeadas y con perfil claramente ovoide, estando bien definido el diámetro máximo en el tercio superior del cuerpo. Si bien es cierto que hay algunos ejemplares, como uno proveniente de Benicarló (Ribera i Lacomba y Ripolles Alegre 1977: 168 y 171, fig. 6.3), y otro de las excavaciones de Santa Perpétua de Mogoda (Vallès, Barcelona), que presentan un cuerpo mucho más ancho de lo normal ( $56 \mathrm{~cm}$ en el caso de Benicarló). Por el contrario, hay otros, como es el caso del ejemplar de Ampurias dado a conocer recientemente ( Berni Millet 2008: 82), que probablemente pertenecen a un momento más avanzado dentro de la producción del tipo, cuya configuración del cuerpo y del cuello prácticamente se inscriben ya en la línea de las posteriores Oberaden 83.

La forma de los pivotes parece variar bastante, aunque hay que destacar que en la gran mayoría de los casos cuentan con 5 y $7 \mathrm{~cm}$ de altura y suelen ser macizos, con un perfil troncocónico y parte inferior ligeramente protuberante, aunque no se descarta que en algún caso puedan ser huecos o semihuecos, es decir, con un relleno de arcilla más pequeño, como parece entreverse en la pieza presentada por P. Berni (2008: 82. Fig. 28) procedente de Ampurias. Igualmente, en Scallabis (Santarém) se documentaron un gran número de este tipo de fondos (tipos III y V), que se han atribuido a la mayor parte de los tipos ovoides ahí identificados (Almeida 2008: $180 \mathrm{ss}$ ).

Igualmente, pensamos que el cuello presenta características más o menos comunes, y que la diversidad observada es una consecuencia directa de la modulación de los cuerpos. De ese modo, aunque los diámetros del mismo pueden variar considerablemente ${ }^{22}$, la mayoría se presenta de tendencia recta y no excesivamente amplios. No obstante, en ejemplares como los de Santa Perpétua de Mogoda y Lomba do Canho, en los que el cuerpo es bastante más ancho en su parte superior, éste asume un perfil corto y bitroncocónico, detalle que conlleva naturalmente a la aplicación de asas más cortas y sobreerguidas con relación al punto donde ambos se unen. (Figs. 22 y 23).

Desde el cuello se da paso a un borde que puede presentarse de varias formas, contándose con ejemplares en los que aparece ligeramente exvasado y "almendrado" (Lomba do Canho, Santa Perpétua de Mogoda, Castro Marim, algunos de Mesas do Castelinho o de

22. Hay que destacar el cuello exageradamente estrecho que presenta el ejemplar casi completo que se encontró en el área portuaria de Itálica (García Vargas e.p.).
Saint-Roman-en-Gal), en otros suavemente lanceolado al exterior, con la parte superior de tendencia apuntada y la inferior marcando la ruptura con el cuello (Mataró, los primeros de Santarém -grupo IX.1 local- algunos de Castro Marim y de Mesas do Castelinho o otros de Saint-Roman-en-Gal). Sin embargo, en la mayoría de los ejemplares suele ser recto al interior y redondeado o engrosado al exterior, donde la parte inferior del borde suele tener una arista bien señalada, que marca claramente su separación del cuello (Ampurias, Malard, Santarém -grupo IX.4 local-y Faro, Castelo da Lousa, Ampurias, Itálica, Sevilla, Lyon-Loyasse, Lyon-Cybèle). Cabe decir que el análisis de los yacimientos mejor conocidos, con limites cronológicos bien determinados, parece revelar una mayor concentración de los últimos subtipos de bordes descritos en contextos fechados entre 40/30-20 a.C.

El perfil de las asas varía en función de la morfología del cuello y del cuerpo, de los que dependen directamente, pudiendo discurrir en paralelo al cuello, o ser más abiertas y redondeadas, inclinándose suavemente hacia el cuello. Sin embargo, un elemento constante y que se revela como un aspecto clave para su identificación, es la sección. En la totalidad de ejemplares conocidos es siempre ovalada y con un surco longitudinal que la recorre en toda su extensión, y que puede ser más o menos pronunciado, siendo rematado con una profunda digitación. Estas características, comunes a otros tipos ovoides y a la Haltern 70, están ausentes por completo en los tipo Oberaden 83 y Haltern 71, lo que, en términos cronológicos, se traduce por su desaparición en los contenedores olearios en el segundo decenio a.C.

En ejemplares muy fragmentarios, que parecen tener cuellos menos altos y cuerpos más "cilindricos", encontrándose ya muy cerca de las características definitorias de las Oberaden 83, únicamente las secciones de las asas y los pivotes nos impiden clasificarlas como tales. Este parece ser el caso de ciertas piezas halladas en contextos lioneses, como algunas del horizonte 2 del santuario de Cybèle (Lemaître y otros 1998), o sobre todo del depósito 3 de Montée de Loyasse datado entre el 30 y 15 a.C. (Desbat y Lemaître 2001). Por último, hay que resaltar que en el yacimiento luso de Castelo da Lousa (Morais 2010a), aparecieron algunos ejemplares que han de ser clasificados como Ovoide 6 (estampa XXXIII, 63 y 64, pág. 211), si bien la tónica general que parece apreciarse de las figuras expuestas se acerca más a tipos como Oberaden 83 e incluso algún borde podría entrar en la categoría de Haltern 71.

Gran parte de las características que acaban de ser descritas para el tipo Ovoide 6 nos conducen claramente 


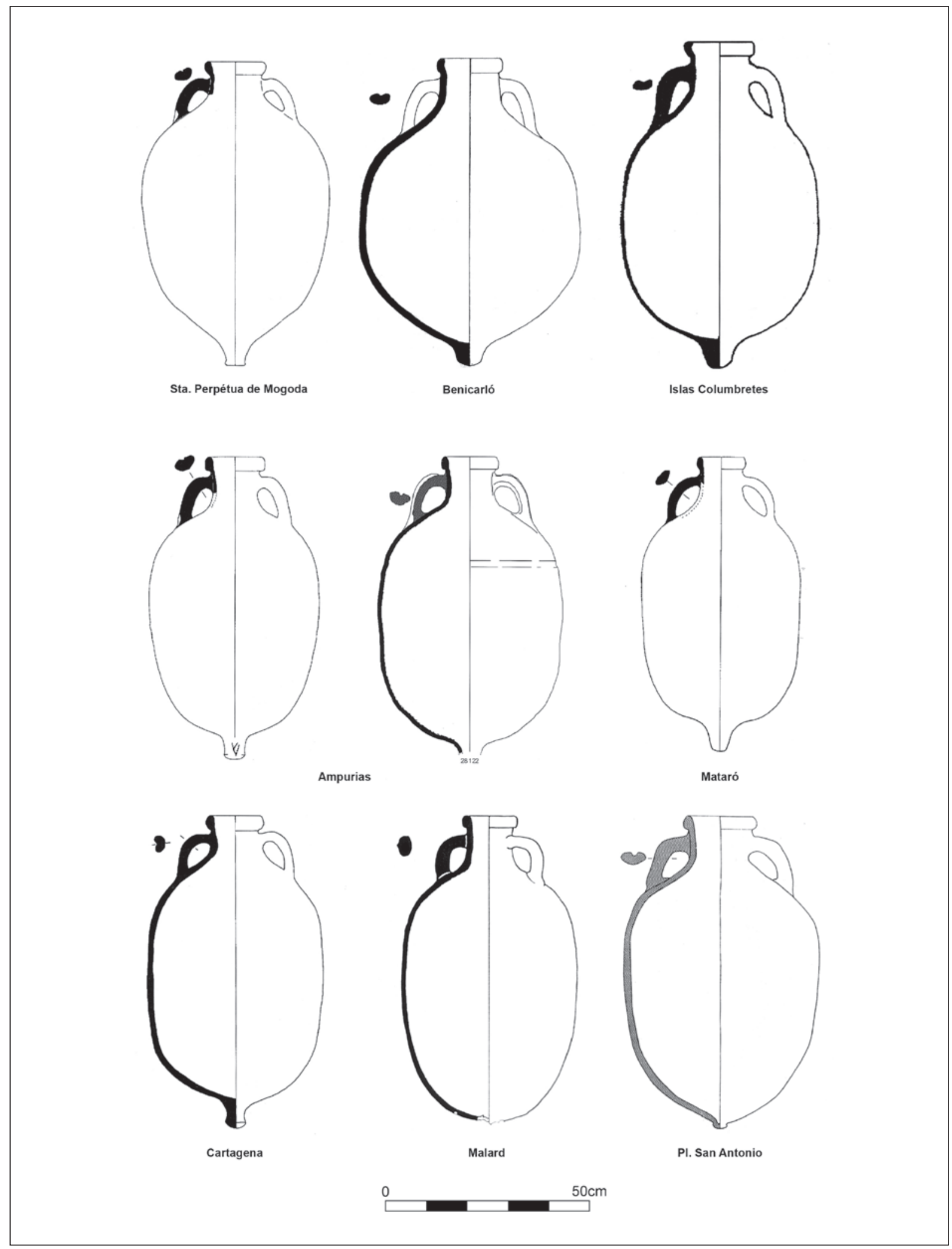

Figura 22. Ejemplares completos de Ovoide 6 (según Berni Millet 1998 y Almeida 2008, revisado y ampliado). 


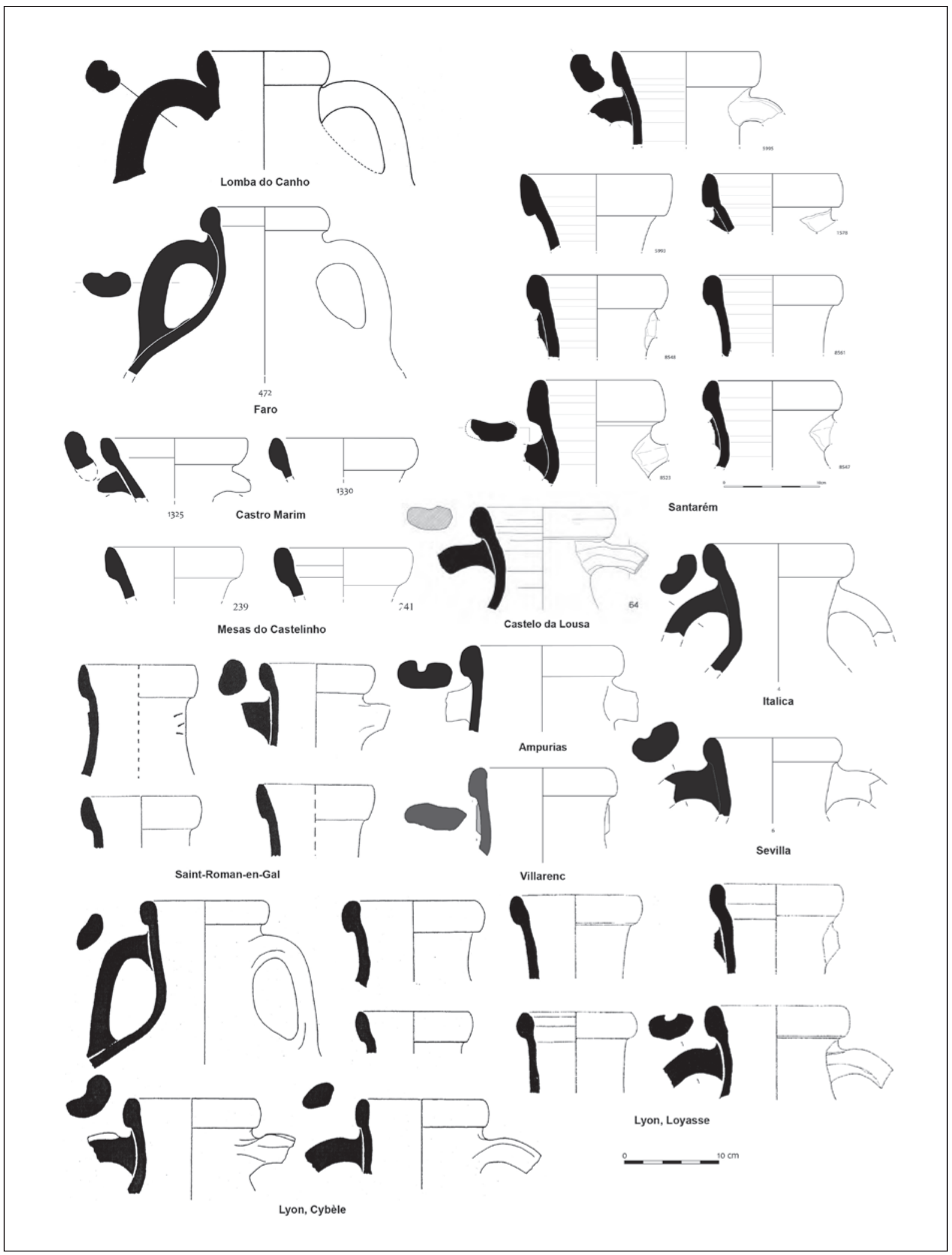

Figura 23. Ejemplares fragmentarios atribuibles al tipo Ovoide 6. 


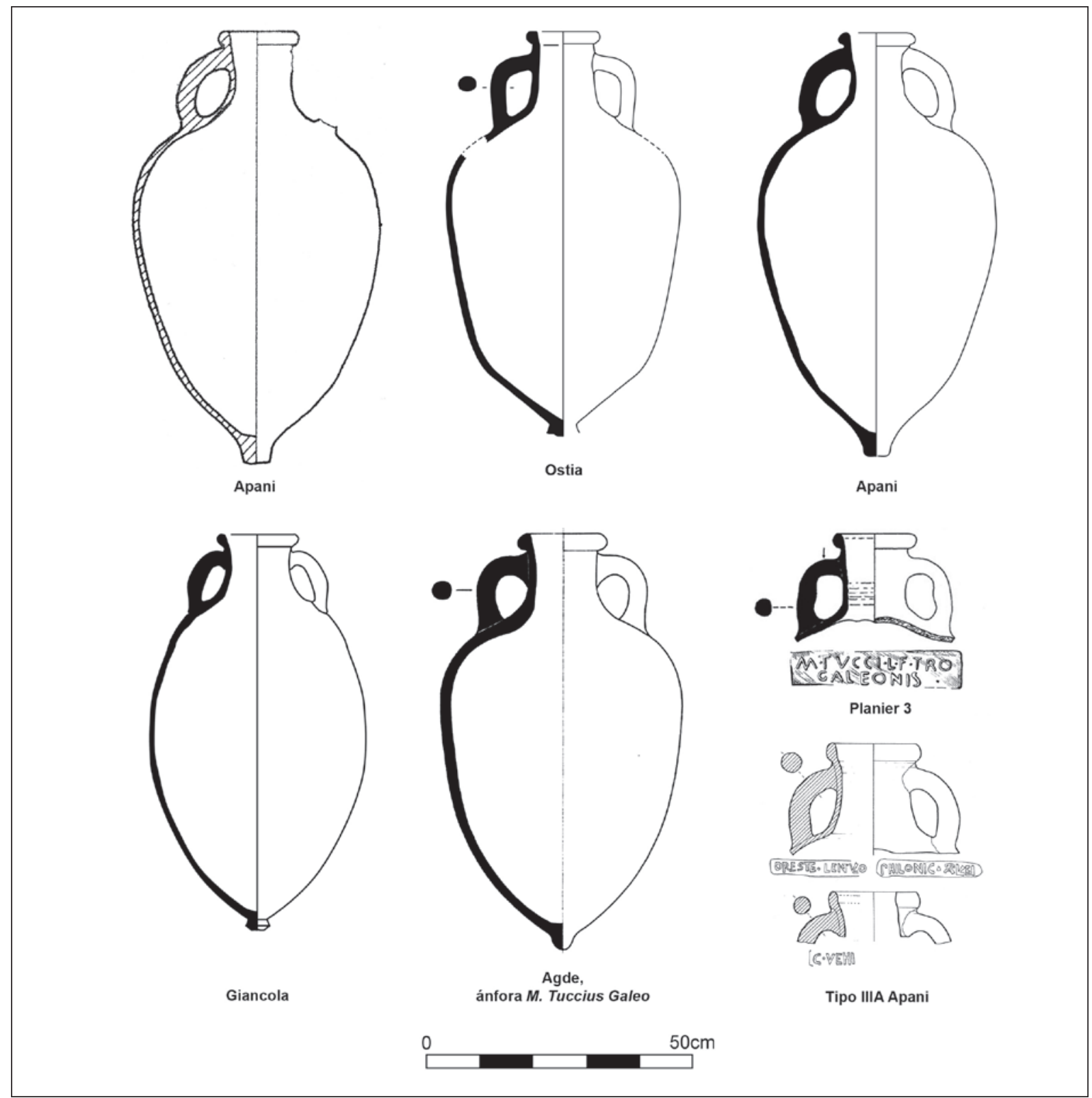

Figura 24. Tipos ovoides brindisinos relacionables con el tipo Ovoide 6 del Guadalquivir.Arriba: Apani (Palazzo 1989), Ostia (Panella 1973), Galia (Loughton 2003). Abajo: Giancola (Manacorda 2001), Agde (Cipriano y Carre 1989), Planier 3 (Tchernia 1968-1970), Apani (Palazzo 1989).

hacia la filiación con las ánforas ovoides apulas, especialmente con algunos ejemplares de los poco claros tipos I o IV de Baldacci (1972), del tipo III de Apani, $\mathrm{y}$ creemos que principalmente con el grupo de ánforas con sello M. Tuccius Galeo (Cipriano y Carre 1989: 74-77), que tal vez no fuera producido exactamente en la región apula. A tenor de los hallazgos de este grupo, concretados en Italia del sur y tirrénica, así como en la
Narbonense y comparando las dataciones de los mismos, parece ser un contenedor producido y exportado en un momento ligeramente posterior a las fechas de máxima expansión de la producción brindisina, centrada en la primera mitad del I a.C, y llegando a época augustea inicial tal como se deduce de la evidencia del alfar de Giancola (Carre y Mattioli 2003: 460). Tipológicamente, pensamos que el ejemplar procedente de las 
Termas del Nuotatore de Ostia (Panella 1973: 494-496; 625 , fig. 2, con el número 66), cuya presencia en un contexto de época flavia es ciertamente residual, entraría dentro del grupo M. Tuccius Galeo. (Fig. 24).

Antes de seguir adelante, conviene destacar un ejemplar encontrado durante las excavaciones de la plaza de San Antonio en el centro de la parte antigua de la ciudad de Cádiz (fig. 22), ya que pensamos que es la mejor muestra del parentesco suditálico. Cuenta con un cuerpo similar al que C. Panella (1973) presenta en su número 66 de Ostia, y sobre todo al de la figura 7 de M. T. Cipriano y M-B. Carre (1989: 75). Sin embargo, la pieza gaditana se diferencia de las anteriores en que acaba en un pequeño pivote que parece querer imitar a menor escala la típica forma de los fondos de las ánforas de tradición griega (entre las que habría que incluir el repertorio suditálico), pero que por el contrario, es hueco en su interior, mostrando, a nuestro parecer, un rasgo típico de las ánforas de tradición púnica sudhispanas. Igualmente, las asas se inclinan suavemente hacia el cuello y la sección muestra el característico surco dorsal de otras producciones del valle del Guadalquivir (a modo de una marca de fábrica). Es cierto que la parte superior del ejemplar de Ostia y de otras piezas del grupo de M. Tuccius Galeo, son más altas, rectilíneas y con mayor distancia entre el borde y el inicio de las asas, pero si observamos otros envases que hemos clasificado como Ovoide 6 (Clase 24), nos damos cuenta que guarda enormes paralelismos formales.

Volviendo a la pieza de Cádiz, nos encontramos que el tipo de pasta nos indica un lugar de producción en la propia bahía gaditana, lo que parece corroborarse a nivel formal al presentar un pivote hueco, algo que como ya ha sido mencionado, es un rasgo típico de la tradición púnica gadirita y se observa en las ánforas de salazones del Estrecho. No obstante, la producción de tipos olearios en zonas costeras de la Bética es de sobra conocida $^{23}$. La diferencia con el valle del Guadalquivir es sobre todo cuantitativa, ya que a pesar de que se ha puesto de manifiesto la existencia de almazaras y estructuras de producción relacionadas con el aceite de oliva (Peña Cervantes 2010; Lagóstena y Mata 2007), su volumen no tiene nada que ver con el del Baetis.

Hay que destacar que en 1969 García y Bellido (1969: 143-144) dio a conocer un sello de M. Tuccius

23. La cronología dada para el contexto de procedencia, que nos sitúa claramente en un momento tardoaugusteo, si bien junto a nuestra pieza aparecen igualmente ánforas ovoides gaditanas, por lo que por lo menos la residualidad de una parte del conjunto parece fuera de toda duda e impide datar nuestra pieza con mayor exactitud.
Galeo sobre un asa proveniente de unos movimientos de tierras para la construcción de unas viviendas frente a la playa de la Caleta, también en el casco viejo de Cádiz, a poca distancia de la plaza de San Antonio. El autor no cita un contexto estrátigráfico concreto, pero creemos que ya es de por sí significativo que el único sello de este tipo con el que se cuenta en todo el sur hispano, se haya encontrado en el mismo núcleo urbano donde se encontró una copia tan similar.

Actualmente, el número de piezas documentadas pertenecientes al tipo Ovoide 6, sin ser excesivamente numeroso, sí que nos muestra que contaron con una buena distribución a nivel local/regional que hasta hace poco tiempo era desconocida (Almeida 2008: 145146), pero que igualmente sobrepasa los límites de la Península Ibérica, penetrando por el sureste francés y llegando a lugares como Narbona, la región lionesa e incluso al área suiza donde se constata la presencia de un ejemplar en Augusta Raurica en un contexto anterior a la fundación colonial (Martin-Kilcher 1999).

En lugares de consumo y de producción de la Ulterior, contamos con algunos ejemplares que confirman las impresiones obtenidas en otros ámbitos. En el alfar de Jardín de Cano, en el Puerto de Santa María (López Rosendo 2008; López Rosendo 2010) se documenta un tercio superior de esta tipología junto con Dressel 1C locales y ánforas de la forma LC 67. Es una pieza con pastas del Guadalquivir en un contexto productivo con material claramente gaditano, pero homogéneo en fechas (60-30 a.C.) En la bahía de Algeciras, en la alfarería de El Rinconcillo (infra) existen ejemplares de la forma de los que carecemos de datos para asignarlos a producciones locales o a importaciones desde el interior (Fernández Cacho 1995, fig. 7.12-13). Volviendo al área gaditana, las ánforas Clase 24 del alfar de Rabatún, en Jerez de la Frontera (Cádiz: García Vargas y López Rosendo 2008: 294, fig. 10 9-11) tienen las mismas pastas que el resto de las producciones del alfar, lo que ratifica la idea de que se trata de un tipo que se produjo simultáneamente en el área cercana a la bahía de Cádiz y en el interior del Guadalquivir, siendo, como en el caso de las Haltern 70 o de las Ovoide 1 (=Clase 67/LC 67) las producciones del Guadalquivir las más numerosas.

En el entorno del bajo Guadalquivir, merece la pena destacar la presencia de algunos fragmentos de la forma en niveles augusteos del alfar de la calle Doctor Fleming 25 de Carmona (cf. García Vargas 2010: 597), ciudad en la que se debió producir (aunque no hay fragmentos pasados de cocción) junto a otros tipos mayoritarios como Ovoide 4 y Haltern 70. En Itálica, el depósito anfórico del área portuaria que contenía Dressel 1, 
Ovoide 1 y Ovoide ¿2? presenta también un cuerpo carente de boca de Ovoide 6 con pasta del Guadalquivir (García Vargas e.p.), junto a un cuello completo de la misma procedencia. Igualmente, dentro de una cronología amplia de la segunda mitad del siglo I a.C. apareció un cuello probablemente residual procedente de la UE 161 de la calle Alemanes $n^{\circ} 25$ de Sevilla (García Vargas 2009: fig. 4.15), mientras que unos hombros con arranques de asas (UE 1921, $\mathrm{n}^{\circ}$ inv. 1702) y un borde, adscibible al subtipo XI.1 de Santarém (Almeida 2008: fig. 58) de la UE 1818 del Patio de Banderas ( $n^{\circ}$ de inv. 1578) deben corresponder a momentos en torno al tercer cuarto del siglo I a.C. (García Vargas e.p).

A nivel de difusión extrapeninsular, además de los contextos galos, hay que indicar que el Norte de África, podría ser otro de los ejes exportadores para este tipo, ya que dentro del material de la fase púnico-mauritana II de Lixus (Aranegui y otros 2001), hoy en día pueden constatarse algunos ejemplares de Ovoide 6 (Clase 24). Decimos hoy en día pues si bien los dibujos de la publicación de 2001 no permitían determinar si eran ovoides tardorrepublicanas o se ya se trataban de Oberaden 83 (como parecia ser el caso), los nuevos hallazgos testimonian la presencia del tipo más antiguo (Bonet Rosado y otros 2005: 122-123, fig. 16).

Por desgracia, la mayoría de los contextos de recepción de la forma Ovoide 6 en el espacio extra-provincial no parecen ser demasiado concluyentes y no contamos con la precisión cronológica que tenemos para los envases de época augustea (infra). Asimismo, y a pesar de la difusión exterior con la que contaron, hay que destacar que las Ovoide 6 (Clase 24) presentan una gran variabilidad morfológica, más acusada que en otros tipos de ánforas ovoides sudhispánicas, lo que en cierta medida sorprende si tenemos en cuenta que difusión exterior y estandarización formal suelen ir unidas. A pesar de dichas lagunas, en piezas como la de Ampurias (Berni 2008: 82), de Malard (Anteas1993, 86-87), de Cartagena o Mataró (Pérez Suñé y Revilla Calvo 2001: 596), parece intuirse, hacia los momentos finales de producción del tipo, un cierto desarrollo formal, que llevaría a que estos envases se fueran distanciando cada vez más de los modelos apulos, evolucionando hacia las características de los envases olearios augusteos, aspectos que se pueden apreciar sobre todo al nivel del cuerpo y asas ${ }^{24}$.

24. En Malard, a las afueras de Narbona (Anteas 1993: 86-87), apareció un ánfora que cuenta con un cuello más estrecho y alargado, con asas que transcurren aproximadamente paralelas al mismo, de perfil ovalado y con mayor separación entre su final y el inicio del
La presencia extrapeninsular de Ovoide 6, sobre todo circunscrita al área sur de la Galia y al eje fluvial del Ródano, marca ya la tendencia que va a desarrollarse a partir de época de Augusto, abriendo el que será uno de los mercados más importantes de las productos del valle del Guadalquivir durante el periodo romano.

\subsubsection{Cuarto grupo. Primeras exportaciones masivas en época augustea. Último paso hacia la estandarización.}

Durante el principado de Augusto y en gran medida una vez que las guerras de conquista de la cornisa cantábrica han completado con éxito la unificación de todo el ámbito peninsular bajo el dominio de Roma, puede asegurarse que asistimos a una nueva fase productiva en las alfarerías hispanas, a la cual no son ajenos los centros del valle del Guadalquivir. El final de las operaciones militares en el norte de Hispania hacia el 19 a.C., supone la liberación de un gran número de soldados que van a contribuir a acelerar el proceso de "romanización" al participar en las tareas de construcción de infraestructuras de todo tipo, fundamentales para la comunicación y ordenación de los distintos territorios hispanos. Junto con ello, un gran número de soldados son licenciados y empiezan a participar activamente en la vida urbana peninsular, debido tanto al hecho de que adquieren tierras en el territorio de antiguas colonias y municipios hispanos, como principalmente gracias a la creación de nuevas colonias romanas, algunas de tanto calibre como Caesaraugusta, Augusta Emerita, o Barcino. Este hecho supuso la creación de una gran masa de consumidores "urbanos", que incidió en la consolidación y aumento del mercado interior dentro de Hispania.

No obstante, creemos que para la producción agropecuaria hispana en general, y del valle del Guadalquivir en particular, durante el principado de Augusto hay un hecho aún de mayor trascendencia que la formación de un mercado interno de cierta relevancia. Nos estamos refiriendo a la creación y consolidación de los dos

borde, que por su parte es recto y redondeado en su cara externa. A ella le podríamos sumar otra pieza aparecida en Mataró en un contexto datado entre el último cuarto del siglo I a.C. y el primero del I d.C. (Pérez Suñé y Revilla Calvo 2001: 596), si bien las asas se inclinan sobre el cuello. Aún más cercanas parece estar la parte superior de una pieza aparecida en el santuario de Cibeles en Lyon ( Lemaître y otros 1998: fig. 9, 1). Curiosamente, estos tres ejemplares, a pesar de contar con asas de sección oval, no tienen muy marcado el surco dorsal de las mismas. 
mercados extrapeninsulares más importantes para los productos de las tierras, campos y mares hispanos durante todo el periodo romano. Estos no son otros que el mercado militar de la nueva frontera septentrional y el mercado civil de Roma ${ }^{25}$.

La recepción de las importaciones hispanas en el área germánica constituye el tema de tesis doctoral de uno de nosotros, por lo que estamos en condiciones de afirmar que, una vez concluidas las campañas cántabras, un gran número de los contingentes son enviados desde allí a la frontera germana, que pasa a ser el nuevo teatro de operaciones militares de relevancia, contando con una enorme concentración de efectivos a partir del segundo decenio a.C. Se ha de tener en cuenta que los inhóspitos territorios en torno al Rin, tanto por su clima como por su geografía, nunca fueron propicios para el cultivo y elaboración de un buen número de bienes típicos de la dieta y forma de vida mediterráneas, la cual era considerada fundamental para el buen funcionamiento de la cotidianidad de las legiones romanas (Davies 1971). La ausencia de bienes tan básicos como el aceite de oliva, el vino y en este primer momento de conquista probablemente la sal, supuso un desafío logístico al que la administración romana nunca se había enfrentado con anterioridad y que debía ser resuelto con celeridad y de la manera más eficaz posible. Como bien nos muestran los restos arqueológicos encontrados en los distintos campamentos de época augustea en el área del Rin, para dar respuesta a esta problemática se puso en funcionamiento la maquinaria estatal en una gran cantidad de las provincias que conformaban el naciente Imperio romano, llegando hasta ellos productos de territorios tan distantes como la costa del Levante y el $\mathrm{Egeo}^{26}$. Sin embargo, es evidente que, en función prin-

25. El tema de la exportación de aceite de oliva bético hacia el norte de Europa y Roma ha sido estudiado desde muy diversos aspectos, haciendo que la bibliografía al respecto sea muy variada. Únicamente destacaremos algunos trabajos, sobre todo centrándonos en la investigación hispana, como pueden ser los dos congresos dedicados a la producción y comercio de aceite en la Antigüedad, celebrados en Madrid y Sevilla a inicios de los años 80, el volumen editado por Paul Erdkamp en el año 2002 titulado The roman Army and the Economy, los trabajos de la escuela española de Roma en el Monte Testaccio, o los realizados por el profesor José Remesal Rodríguez sobre la exportación de aceite bético a Germania.

26. Creemos que excede el ámbito de este artículo el analizar el grado en el que la administración romana participa en la llegada de ciertos productos a los campamentos del Rin. No obstante, somos de la opinión que si bien es cierto que habría ciertos productos como los dátiles del Levante o algunos vinos de especial calidad como los de Chios, Cnidos o Falerno, que habrían sido consumidos por la jerarquía militar y que probablemente hubiesen llegado gracias a la acción de negotiatores privados, éstos habrían seguido las líneas de cipalmente de los restos anfóricos, pero también de los toneles que nos encontramos en un buen número de yacimientos germanos (Marlière 2002), fueron las provincias occidentales las que en mayor número contribuyeron a suplir a las tropas en campaña, y hay que destacar en este periodo histórico que va de inicios del segundo decenio a.C., hasta el segundo cuarto d.C., el porcentaje abrumador, prácticamente de monopolio en productos como el aceite de oliva y las salazones, que las importaciones béticas alcanzan en dichos yacimientos.

Junto al extraordinario mercado militar que acababa de abrirse en Germania, se encontraba el no menos importante y ascendente mercado urbano de Roma. A pesar de los cruentos episodios de las guerras civiles que sacudieron el convulso siglo I a.C., el aumento poblacional de la capital del mundo romano durante este periodo fue espectacular, motivado en gran parte por la expansión del sistema de producción latifundista basado en la mano de obra esclava (Carandini 1981), que enviaron a muchos medianos y pequeños campesinos itálicos a formar parte de la plebe urbana. Igualmente, la concentración de riqueza en la capital del mundo romano, que al ser el lugar desde el que se administraba y dirigía un imperio plenamente mediterráneo, atraía a las fortunas más importantes del momento, aumentó las posibilidades de comercio de la urbs, influyendo en su capacidad de importación. Este crecimiento y concentración demográfica no parece tener precedentes en el Mundo Antiguo, conformando una masa de consumidores que apenas producían una minúscula parte de lo que consumían y por lo tanto, al igual que las tropas en Germania, demandaban todo tipo de $\operatorname{productos}^{27}$, que eran traídos desde todos los rincones del mundo romano. A tenor de yacimientos fechados en estos momentos como La Longarina (Hesnard 1988), o posteriores, como los presentados por G.Rizzo (2003) datados entre época de Nerón y la mitad del siglo II d.C. y sobre todo, gracias al extraordinario documento que supone el Monte Testaccio, puede asegurarse que la Bética jugó un papel esencial en el aprovisionamiento de Roma durante todo el periodo imperial, fundamental-

comercio abiertas por el interés del Estado para que se crease una corriente suministradora de los productos básicos carentes en Germania. Para nosotros esta corriente estaría bajo un control riguroso de la administración romana, reforzada aún más tras los sucesos de Dalmacia del 5-6 d.C.

27. Es evidente que en Roma las grandes fortunas demandaban bienes de lujo, que no tienen que ver con los bienes básicos consumidos por las capas sociales más humildes. Sin embargo, tanto unos productos como los otros provenían de todos los rincones del mundo romano e incluso de fuera de sus fronteras, y llegaban mayoritariamente vía marítima al puerto de Ostia. 
mente como principal región exportadora de aceite de oliva, un producto cuya utilidad en la Antigüedad mediterránea traspasaba el mero ámbito alimenticio.

En este panorama de aumento sin precedentes de las demandas de productos anfóricos y dentro del clima de estabilidad que se había creado después de Accio, no es de extrañar que, una vez completado un periodo que podría calificarse como de puesta en funcionamiento y formación de una base agropecuaria de alta productividad y de toda la serie de industrias subsidiarias que giran en torno a la misma, la producción sudhispana se encontrara en unas condiciones óptimas para poder dar respuesta a las grandes demandas que se planteaban en el Occidente del mundo romano. Este proceso de causa-consecuencia tuvo un efecto inmediato en los envases del valle del Guadalquivir, asistiéndose a una nueva transformación tipológica en pro de la definitiva estandarización formal.

En los dos últimos decenios antes de nuestra era, observamos la progresiva desaparición de la mayor parte de los tipos caracterizados anteriormente, y cuya fase de mayor producción se había alcanzado en el tercer cuarto de siglo I a.C. Para la debida comprensión de lo que se podría denominar como el final del primer ciclo de la producción anfórica romana del valle del Guadalquivir, cabe destacar que en los campamentos germanos o en los yacimientos de la vertiente norte de Europa, Galia incluida, hasta la fecha estudiados, no han aparecido fragmentos que puedan ser asimilables con los tipos ovoides del Guadalquivir, sin que haya rastro de que sean las Ovoides 1 (Clase 67/LC67) 4 o 5, en este caso un posible fragmento de Ovoide 5 en Dangstteten que no cambia en nada el panorama trazado.

De este modo, a partir de c. 20/15 a.C., y hasta el segundo tercio del I d.C., contamos con tres tipos anfóricos fundamentales dentro de la producción del valle del Guadalquivir, como son las Oberaden 83, las Haltern 71, y las Haltern 70. Las tres son muestra inequívoca del nuevo rumbo que parece estar tomando poco a poco la producción anfórica, desapareciendo paulatinamente las formas de tipo ovoide.

\section{Oberaden 83 (fig. 25)}

Se trata de un tipo oleario que a día de hoy sigue siendo clasificado como Dressel 20 por un buen número de investigadores, pero que en realidad resulta evidente que ha de ser enmarcado dentro del denominado Tipo A de contenedores olearios augusteos señalados por P. Berni (1998: 26-28). Fue presentado por primera vez de forma individualizada por S. Loeschke en sus trabajos sobre el material del yacimiento germano de Oberaden (Loeschke 1942) y es de ese mismo lugar de donde toma su nombre al ser clasificado por el investigador alemán con el número 83 de la tabla del material cerámico. El propio marco cronológico del yacimiento alemán, con un preciso intervalo que va del 11 a.C. al 8-7 a.C. ${ }^{28}$, nos indica el periodo de vida de esta tipología, que debió de estar en vigor en las dos últimas décadas antes de nuestra era.

Formalmente, es un ánfora que aún muestra una marcada heterogeneidad, probablemente debido a que si bien es cierto que está camino de conseguir cierta estandarización, aún le queda bastante para llegar a ella. A grandes rasgos, puede afirmarse que presenta un cuerpo todavía un tanto ovalado o incluso cilíndrico, aunque en ocasiones tiene tendencia globular, con una altura media que sobrepasa los $70 \mathrm{~cm}$. En su parte inferior aparece un pequeño pivote semi-macizo (no supera los $8 \mathrm{~cm}$ de altura), que en su parte externa inferior es semiplano con los bordes redondeados, y que al interior presenta el característico botón o pella de arcilla de las producciones del Guadalquivir, que no sobrepasa los $4 \mathrm{~cm}$ de altura. Muchos pivotes muestran grafitos ante cocturam, bien sean equis o cruces en la cara exterior, astas, o pequeñas incisiones de los dedos del alfarero en la parte superior de las pellas de arcilla. Estas marcas parecen ser una característica común a los talleres del Guadalquivir durante el periodo augusteo, como evidencia el que también aparezcan en Haltern 70 y Haltern 71 .

En su parte superior, se caracteriza por tener un cuello más o menos recto, que acaba derivando suavemente en un borde ligeramente exvasado. El diámetro de la boca suele estar entre los 13 y $15 \mathrm{~cm}$, aunque es cierto que hay ejemplares que pueden superar los 15 . Cuenta con una altura por encima de 3 y normalmente sin sobrepasar los 4,5-5 cm. La forma del labio es lanceolada o ligeramente almendrada, con la parte superior redondeada, tanto en su cara externa como interna. A pesar de que hay ejemplares con labios bastante rectos y cuellos ligeramente exvasados, en ocasiones se observan cuellos más rectos con bordes más salientes.

28. Los campamentos del valle del Lippe, donde se encuadra Oberaden, tienen una datación excepcional, debido tanto a la falta de ocupaciones posteriores al breve periodo de presencia romana, como al buen estado de conservación de los restos lígneos, que permiten hacer exhaustivos análisis dendrocronológicos. Al margen de ello, las series monetales y cerámicas nos aportan unos datos cronológicos también muy precisos que vienen a confirmar las dataciones (Schnurbein 1981). 
Para conseguir esta segunda solución formal, parece recurrirse a una ligera hendidura que se presenta en la zona media o inferior de su cara interna y que marca una pequeña carena o ruptura con el desarrollo del cue1lo. Podemos afirmar, que en líneas generales la forma de labio más extendida entre las Oberaden 83 viene a coincidir con el tipo definido como IX.2 para Santarém (Almeida 2008: 144, tabla 5).

Las asas son otro elemento importante a la hora de caracterizar a las Oberaden 83 y poder distinguirlas correctamente de prototipos olearios anteriores y posteriores. Suelen comenzar apenas termina el borde, marcando un suave paso con el mismo. Son de perfil más o menos redondeado, que generalmente se inclina levemente hacia el cuello del ánfora, si bien es cierto que hay ejemplares en los que las asas van más paralelas al cuello del ánfora. Si las comparamos con las asas de las Haltern 71 o de las Dressel 20, no son excesivamente macizas, presentando una sección generalmente redondeada u ovalada y sin acanaladura. Estos son rasgos que individualizan perfectamente a este tipo.

En el estado actual del conocimiento, creemos que las Oberaden 83 empezarían a ser producidas coincidiendo groso modo con la instalación de los primeros campamentos militares en la frontera del Rin, es decir, hacia el 20 a.C. Su principal área de importación parece haber sido los propios campamentos germanos, en donde se hallan en porcentajes muy altos, como ponen de manifiesto Oberaden, Neuss, Dangstetten, Vindonissa o Rödgen (González Cesteros y Tremmel e.p; Carreras y González Cesteros e.p a; Ehmig 2010; MartinKilcher 2003; Schönberger y Simon 1976). Igualmente, una parte de las ánforas clasificadas por S. Martin-Kilcher (1987: 53) dentro del grupo A de las olearias de Augst, pertenecen a esta forma. Son piezas importadas en los momentos iniciales de la colonia Augusta Raurica, fundada en torno al 15 a.C. Sin embargo, pensamos que la mayor parte de ánforas clasificadas dentro de este grupo pertenecen en realidad a la forma Haltern 71 y probablemente fuesen importadas a partir del cambio de era.

Por el contrario, como ya ha sido mencionado, creemos que las ánforas, o por lo menos parte de las mismas, aparecidas en el santuario de Cibeles de Lyon, o las de Loyasse también en Lyon, aún no pueden denominarse Oberaden 83 , sino que todavía habría que incluirlas dentro de las Ovoide 6 (Clase 24). Sin embargo, sí que habría que integrar dentro de nuestro tipo tanto al ejemplar de las excavaciones del taller cerámico de $\mathrm{La}$ Muette (20-0 a.C.), como algunas piezas del horizonte 1 de Saint-Romain-en Gal (30/20-15 a.C.) (Desbat y
Lemaître 2001: 806-811), que serían la continuación de las primeras importaciones béticas del periodo inmediatamente contiguo a la fundación de la ciudad en el 43 a.C., y que irían aumentando progresivamente a medida que Lyon se va conformando como un núcleo civil de primer rango, al amparo de su importantísimo papel como capital de la Galia Lugdunensis (27 a.C.) y como principal eje de comunicaciones terrestres y fluviales hacia el interior de Galia y Europa septentrional.

\section{Haltern 71 (fig. 26)}

El siguiente paso en la evolución formal de los tipos olearios del Guadalquivir lo encontramos en las Haltern 71. En líneas generales estamos de acuerdo en asimilar este tipo con el B de P. Berni $(1998,30)$. En su definición, P. Berni delimita perfectamente el marco cronológico en el que pensamos que se mueven las Haltern 71, es decir, entre el cambio de era y finales de1 reinado de Tiberio. Al igual que las Oberaden 83, el tipo fue presentado por primera vez por S. Loeschcke, pero esta vez en la publicación sobre el material del yacimiento de Haltern en 1909. Dicho yacimiento tiene una ocupación posterior al de Oberaden, con una cronología aceptada entre el 9 a.C. y el 9/16 d.C. Sin embargo, conviene precisar que al igual que en otros yacimientos militares, en Haltern contamos con varios campamentos que se superponen cronológicamente, realizándose la mayor parte de las excavaciones en el área del campamento principal que abarca unas 20 ha, y que a su vez parece tener dos fases debido a que sufrió un proceso de ampliación (Asskamp 2010). Actualmente, el material de Haltern excavado con posterioridad a la segunda guerra mundial está siendo objeto de estudio por uno de nosotros (H. González Cesteros, junto con la Dr. B. Tremmel y el Dr. P. Monsieur ${ }^{29}$ ). Estas excavaciones, como también parece ser el caso de las anteriores al conflicto bélico, se han centrado en la zona del campamento principal, cuya datación parece ser dudosa, pero a tenor de los tipos cerámicos no sería muy anterior al cambio de era, aportando una buena muestra de las tipologías imperantes durante el primer decenio d.C. Por este motivo y por el material presente en otros yacimientos con buena cronología de este periodo, creemos que la forma Haltern 71 aparecería en un momento cercano al cambio de era.

29. Este proyecto de investigación dirigido por el servicio de arqueología de Westfalia y sus resultados verán la luz a modo de una monografía, cuya aparición esperemos no se retrase excesivamente. 


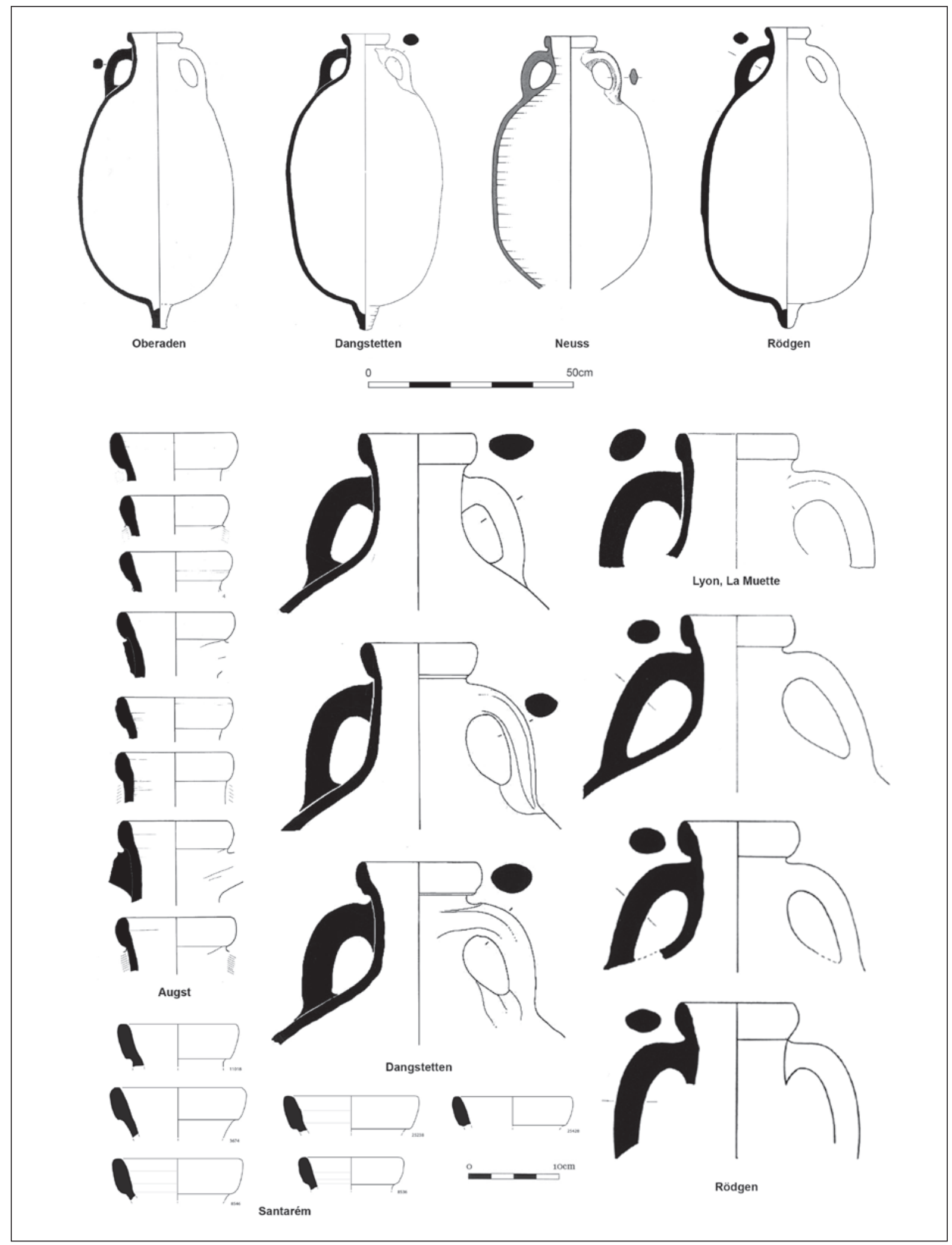

Figura 25. Ánforas del tipo Oberaden 83. 
Se trata de un envase que parte de los rasgos comunes de las Oberaden 83 , con las que en ocasiones es difícil de distinguir si no se tienen fragmentos más o menos amplios, existiendo probablemente formas intermedias o de transición entre uno y otro. Sin embargo, puede decirse que las Haltern 71 ya se acercan bastante a las primeras Dressel 20 de época Julio Claudia, presentando un alto grado de estandarización formal, mayor que en el caso de las Oberaden 83, que incluso parece manifestarse en los módulos de capacidad. Puede afirmarse que son el último paso antes de la aparición de las Dressel 20, un ánfora que se produjo en cantidades astronómicas en toda la Bética y con un elevado índice de estandarización, que hizo que en talleres distantes cientos de kilómetros fueran producidas exactamente de la misma manera, algo que aún no ocurre exactamente con el contenedor augusteo.

Se ha de resaltar que contando únicamente con fragmentos de borde o con pivotes, es bastante difícil poder llegar a discernir si se trata de Oberaden 83 o por el contrario Haltern 71. Incluso en algunos casos, aún con el cuello y las asas puede haber individuos que presenten características conjuntas de ambos tipos, como ocurre entre el material del propio yacimiento de Haltern. No obstante, a excepción de los pivotes, sí que pueden resaltarse ciertas características que individualizan claramente a nuestro tipo.

Formalmente este envase se caracteriza por tener un cuerpo de tendencia globular, si bien se ha de resaltar que los alfareros aún no han conseguido llegar a fabricar ánforas plenamente globulares, algo que conseguirán ya en época Julio-Claudia con las primeras Dressel 20. Dentro de estos intentos, un buen número de Haltern 71 presentan paredes más o menos rectas, que marcan suavemente el paso hacia la parte superior e inferior del ánfora. La altura completa suele rondar los 65$70 \mathrm{~cm}$, ajustándose la gran mayoría de los ejemplares a este canon, lo que es una muestra inequívoca del proceso de estandarización al que están sometidos los envases olearios del valle del Guadalquivir. Los pivotes suelen ser muy similares a los del tipo precedente, tal vez con alturas un poco menores $(5-6 \mathrm{~cm}$, y $2,5-3 \mathrm{~cm}$ la pella de arcilla o botón) y algo más abiertos debido a que el cuerpo es menos ovoide y las paredes inferiores son más rectilíneas. Aún así, como viene de ser mencionado, si únicamente se cuenta con pivotes es imposible llegar a determinar si se trata de uno u otro tipo.

Además del cuerpo, es en la parte superior de las Haltern 71 donde mayor diferenciación se observa con las Oberaden 83. El cuello generalmente es más curvo y de menor altura y acaba en un labio exvasado y más grueso que en el tipo precedente. La boca suele rondar los $15 \mathrm{~cm}$ de diámetro y en general la altura de los labios es algo menor que en el caso de las Oberaden 83 , estando entre 3 y $4 \mathrm{~cm}$ de media. La forma del labio puede variar considerablemente de unos ejemplares a otros, si bien creemos que pueden diferenciarse tres grupos mayoritarios. El primero de ellos sería el más cercano a los tipos olearios precedentes, ya que a pesar de ser más grueso sigue siendo fino y lanceolado, presentándose sin grandes rupturas con respecto al devenir del cuello.

El segundo también guarda semejanzas con algunos labios de Oberaden 83, al recurrir en su cara interna a una hendidura para romper con la dirección del cuello y de esta forma conseguir cierto exvasamiento. Sin embargo, en el caso de este grupo de labios, las hendiduras o surcos suelen ser ligeramente más pronunciados, iniciándose probablemente un desarrollo orientado a crear un borde en el que fijar bien las tapas del envase (Martin-Kilcher 1987: 53), que desembocará en los típicos bordes de las Dressel 20 de época flavia. El último grupo presenta bordes de tendencia rectangular, con la parte superior más o menos plana y con la carena y hendidura muy marcadas. Sobre este tipo de labio se han encontrado los primeros sellos que se tienen sobre ánforas olearias (Berni 2008: 82), procedentes de Haltern y de Augst (Martin-Kilcher: 1987). A pesar de estas diferencias, no podemos establecer ninguna secuencia cronológica entre unos y otros tipos de labios ya que nos pueden aparecer los tres en un mismo yacimiento, como puede ser el caso de Haltern o Anreppen.

Una característica bastante definitoria de este tipo son las asas. La propia proporción del cuello hace que sean más pequeñas y circulares que en sus predecesoras, mostrando generalmente un perfil más redondeado, con mayor separación entre las paredes del cuello y la cara interna del asa. La mayor parte de las ocasiones suelen ir en paralelo a las paredes del ánfora, aunque en algunas presentan una tendencia curva, que las acerca ya al cuarto de círculo. El inicio de las mismas se produce prácticamente desde el labio, juntándose con éste en su parte inferior, donde normalmente se marca un surco más o menos pronunciado en el punto de unión. La parte más elevada del asa sobrepasa este punto de unión y se queda a la mitad o tres cuartos del labio. La sección de las asas marca también alguna diferencia con la de las Oberaden 83, ya que si bien suelen ser circulares, en muchas de ellas observamos una tendencia a que la parte superior de la misma sea apuntada, o incluso hay ejemplares que presentan una pequeña cresta 


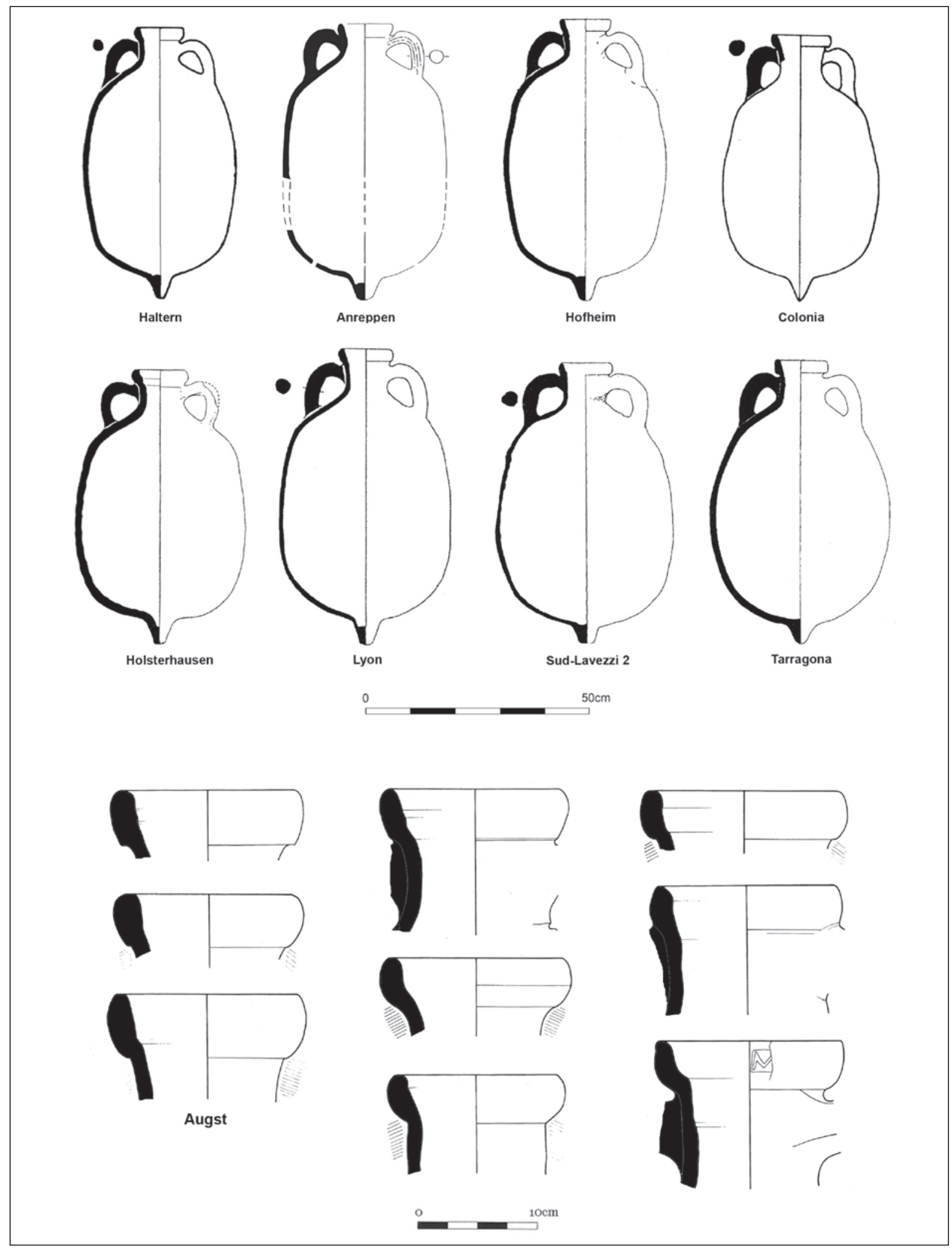

Figura 26. Ánforas del tipo Haltern 71. 
incipiente, que parecen configurar el modo de las posteriores Dressel 20 de época Julio-Claudia.

Como puede verse a raíz de las características aquí descritas, se trata de un tipo que en gran medida anticipa las características formales de las primeras Dressel 20 y que ya está plenamente desligado de las ánforas de tipo ovoide como son las Ovoide 6/Clase 24, pues se encuentra evolucionando y adaptando todas sus partes para alcanzar la forma redonda, algo que acontece probablemente ya en época de Claudio.

A nivel de difusión, los campamentos germanos siguen siendo uno de los destinos prioritarios de las Haltern 71, destacando su presencia en el Kops Plateau de Nimega, en Neuss, en Haltern, Holsternhausen y Anreppen, entre otros. No obstante, es bastante probable que llegaran aún en mayor número a los mercados centroitálicos, especialmente al de Roma. En el depósito ostiense de la Longarina, datado en los 12 primeros años de nuestra era (Hesnard 1980: 141-142) a tenor de las fotografías sobre las piezas enteras, parece observarse la presencia conjunta de Oberaden 83 y Haltern 71 (Hesnard 1980: Plate VI, Fig. 1 y 2). Creemos que está fuera de duda la datación de dicho contexto, pero también que una parte del material anfórico que se presenta debe de ser tomado como residual, lo que explicaría la presencia de ánforas olearias de Bríndisi, Tripolitanas I, o la citada Oberaden 83.

\section{Haltern 70 (figs. 27-30)}

Las ánforas de la forma Haltern 70 constituyen uno de los tipos occidentales que más tinta ha hecho correr en la bibliografía especializada. Al igual que las Haltern 71, fueron individualizadas por S. Loeschke en su estudio del campamento militar de Haltern (Loeschke 1909: 388-389), y englobadas por él mismo dentro de la forma 82 de Oberaden (Loeschke 1942). A pesar de darle un número aparte a esta tipología, Loeschke (1942: 100) y una gran parte de los investigadores de la primera mitad del siglo XX engloban a las hoy tan bien conocidas Haltern 70, dentro de varias formas de la tabla tipológica de Dressel, principalmente dentro de las Dressel $10^{30}$. La investigación española reprodujo esta equivocación, siendo sistemáticamente incluidas

30. El hecho de incluir a las Haltern 70 dentro de otras formas, fue probablemente motivado por la falta de la misma entre el material que Dressel clasificó en Roma. Su ausencia en los contextos de Castro Praetorio y Monte Testaccio es ciertamente sorprendente, sobre todo en el primero de ellos, con material que parece abarcar los últimos años del siglo I a.C., y la primera mitad del I d.C. Tal vez el bajo dentro del grupo formal de las Dressel 7-11 (cf. Beltrán Lloris 1970) los tradicionales contenedores de las salazones béticas desde fines del siglo I a.C. a fines del I d. C. Habría que esperar a la publicación del barco naufragado hacia 50 d.C. en Port Vendres (Colls y otros 1977: 33 ss.) para individualizarlas como un tipo aparte. Las síntesis más recientes como las de Puig (2004), suscitada a propósito de otro pecio con carga de ánforas béticas, el Culip VIII (VV.AA.: 2003), o la de Berni Millet (2011), han abogado por llevar a cabo una evolución cronotipológica de este tipo que permita diferenciar las diferentes fases de su producción, profundizando con ello en los trabajos previos que, en la misma dirección, habían propuesto ya una síntesis coherente de evolución formal de las Haltern 70, sobre todo imperiales (cf. Martin-Kilcher 1994, Carreras Monfort 2003).

Hoy por hoy, y al margen de las animadas controversias acerca de su contenido específico (García Vargas 2004a; García Vargas 2004b; Carreras Monfort 2004), se asume que es el segundo gran contenedor del valle del Guadalquivir en número de ejemplares producidos y exportados, sólo superado por las Dressel 20 olearias (García Vargas 2001: 88), si bien no es ésta la única zona productora del tipo en la provincia (cf. García Vargas 1998: 95-96).

Aunque se asume que la forma aparece constituida como tal en un momento tan temprano como en la década de 70-60 a.C., como ya se ha señalado al referirnos al tipo Ovoide 4, esta idea parte de una mención a un supuesto ejemplar de este tipo hallado entre la carga del naufragio de Madrague de Giens (Tchernia 1986: 142; Tchernia 1990: 296; ambas sin ilustrar). A pesar de un cierto vacío temporal que abarca desde estas fechas hasta la siguiente constatación de la forma hacia el 30 a.C., entre otros lugares en Lyon (Desbat y Lemaître 2001), se asume también en general que a lo largo de su recorrido cronológico, las Haltern 70 conservaron una morfología bastante homogénea que sólo experimentó transformaciones menores en la forma general del borde, siempre sin moldurar, que pasaría desde los ejemplos de sección subrectangular y poco desarrollo en altura (4-5 cm) a otros de mayor desarrollo (6-7 $\mathrm{cm}$ ), de forma rectangular y perfil relativamente exvasado, que en ocasiones parece tener forma de "embudo" (García Vargas 2010b: 593).

Sin abandonar este esquema general, bien asentado en los estudios sobre este tipo anfórico, quisiéramos también aportar algunas ideas acerca de la constitución

índice epigráfico registrado para el tipo, comparado con el de otros, sea lo que justifique su omisión en la tabla del investigador alemán. 


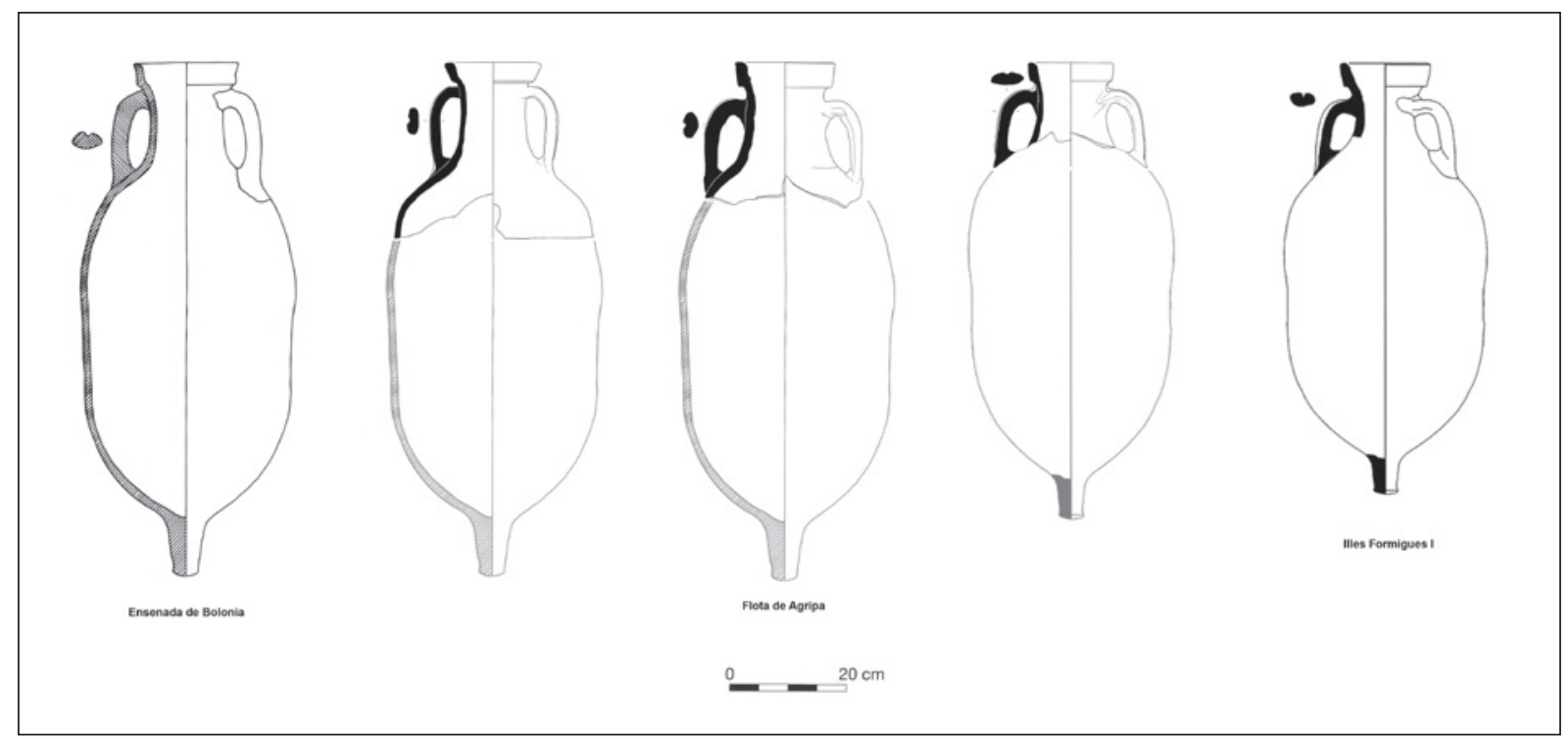

Figura 27. Ánforas Haltern 70 y ¿Ovoide 4? de la Flota de Agrippa, y ejemplares de comparación.

del tipo en los primeros momentos de su "andadura" morfológica, desde su formación como tal hacia la década de los 30 del siglo I a.C., hasta la consolidación de su morfología tal como se constata en los contextos augusteos datados en torno a las dos décadas finales del siglo I a.C. y las iniciales del I d. C.

Al exponer la problemática ligada al tipo Ovoide 4 del Guadalquivir, ya se han señalado las estrechas relaciones existentes entre esta forma y las Haltern 70 (Cf. Almeida 2008: 100-104), probablemente consecuencia de la derivación formal de la una (Haltern 70) a partir de la otra (Ovoide 4), con problemáticos pasos intermedios, de difícil caracterización y rastreo.

Sólo a partir de la fase tempranoaugustea 30-15 a.C. (Puig 2004: 27-29) el tipo Haltern 70 arraiga en el interior de la Bética, donde no se descarta que haya surgido de forma paralela a las series detectadas en la zona costera, si bien a día de hoy parece que lo hizo un poco más tardíamente. Para entonces, las Ovoide 4 parecen haber realizado ya un recorrido formal relativamente dilatado desde sus constataciones más tempranas en Lomba do Canho (60-40 a.C.; Fabião 1989; Fabião 2001), Ampúrias (c. 60 a.C.; Aquilué y otros 2003: 113), en contextos de consumo de Hispalis (50-25 a.C.), Scallabis (segunda mitad del siglo I a.C.: Arruda y Almeida 2001; Almeida 2008) y Mesas do Castelinho (segundo y tercer tercio del siglo a.C.; Parreira 2009). Resulta difícil discernir si las Haltern 70 surgen evolucionando directamente a partir de las Ovoide 4 y dando lugar a las que podríamos denominar "Haltern 70 iniciales" de la costa, o por el contrario evolucionando paralelamente desde la Ovoide 4 y con influencia de tipos vinarios itálicos.

La hipótesis de evolución formal que ahora proponemos, cambia en gran medida los modelos evolutivos existentes, que o bien proponen que estas ánforas se habían inspirado directamente en la Dressel 1 itálica (García Vargas 1998: 98; Étienne y Mayet 2000: 86; Fabião 2001; García Vargas 2001), o defienden que sean resultado de una variación formal a partir de las Ovoide 1/Clase 67 (Molina Vidal 2001: 644, fig.1). Es cierto que la influencia de las Dressel 1 en la formación de las Haltern 70 ha de ser tenida en cuenta, pero por el contrario creemos que es muy arriesgado buscar los antecedentes de esta forma en las Ovoide 1/Clase 67, forma con la que la Haltern 70 apenas presenta similitud formal en ningún aspecto, más allá de representar un cuerpo de tendencia ovoide.

Dentro del proceso evolutivo que aquí proponemos, creemos que las Ovoide 4 parecen dar paso hacia 30 a.C. a un conjunto de contenedores que, de una manera general, se caracterizan por su mayor tamaño, con un cuello más alto o estirado, y en consecuencia, asas alargadas, y cuerpo con mayor longitud. Estos ejemplares con bordes y arranque del cuello diferentes de las Ovoide 4 y más próximas a la morfología "clásica" de las Haltern 70 aparecen, como se acaba de indicar, solamente en contextos fechados en la década de los 30 del siglo I a.C.: Montée de Loyasse, en Lyon (Desbat y Lemaître 2001); Saint-Roman-en-Gal (Desbat y Martin-Kilcher 1989: 362, fig.4); Raurica, Basileia, entre 
40 y 20 a.C. (Martin-Kilcher 1999: 79-83, Tafel 60, nº. 37 y 39); Corts Valencianes, Valencia, con la particularidad de la asociación entre una Haltern 70 "inicial" y otra de morfología ovoide (Pascual Berlanga y Ribera i Lacomba 2001: 576); Patio de Banderas del Alcázar de Sevilla (García Vargas e.p.: fig. 11.2), etc. Entre 30 y 20 a.C., dichas "Haltern 70 iniciales", por llamarlas de algún modo, conviven aún con las Ovoide 4, como parece ser el caso de un ejemplar de posible reconstrucción (Figura 27) del conjunto del campo de la Flota de Agrippa (Goudineau y Brentchaloff 2009), lo que hace que a menudo se confundan unas por otras. Sin embargo, como ya hemos remarcado a lo largo de este trabajo, entendemos actualmente que se trata de dos series diferentes, de las que la primera (Ovoide 4) inicia su producción en un periodo precedente a la segunda (Haltern 70).

Al margen de las diferencias existentes entre ambos tipos, hay que resaltar que en el panorama de las "Haltern 70 iniciales" creemos apreciar una considerable variabilidad formal a la vez que una marcada diferencia con los ejemplares del mismo tipo documentados en contextos ya posteriores al 20 a.C. Así, dentro de estas Haltern 70 que denominamos de "primera época", o iniciales (entre 30-20 a.C.), se pueden documentar principalmente tres grandes grupos morfológicos. (Fig. 28).

El primero sería un grupo de ánforas que presenta una flexión exagerada de las asas dibujando un arco muy violento, en trayectoria generalmente ascendente y que acaba en unos hombros próximos y bien marcados. Estas asas arrancan próximas o directamente pegadas al borde, por lo que hemos de suponer un cuello relativamente corto, significativamente diferente del propio de las Haltern 70 clásicas, y más cercano al de las morfologías ovoides precedentes. El borde se presenta subrectangular y prácticamente en la continuación del cuello. Este es el caso del ejemplar del depósito de Montée de Loyasse (Desbat y Lemaître 2001: 805, fig. 6), de piezas de Santarém (Almeida 2008: 114; grupo VI1B y VI2B) o de Carmona (García Vargas e.p.: fig. 12.2).

El segundo es un grupo con características particulares. De cuello alto y con tendencia más cilíndrica que bitroncocónica, presentan un labio macizo, con perfil subrectangular, engrosado, sobre todo en su parte superior, y netamente separado de la pared, constituyendo un destacado collarín. El cuerpo parece configurar una tendencia aún levemente ovoide, con las asas terminando en la base del cuello más que en los hombros. La forma del bocal y del cuello recuerdan tipos itálicos, tanto las
Dressel 1 como algunas Lamboglia 2, pero en un cuerpo de morfología más ovoide. Los ejemplares conocidos que podemos tomar como referencia para esta tipología radican en un conjunto de piezas relativamente completas procedentes del llamado "Campamento de la flota de Agrippa”, en Fréjus (Goudineau y Brentchaloff 2009: 546, planche. 1), y un ánfora completa (fig. 30, arriba, centro) procedente de las prospecciones de la Universidad de Zaragoza de la ensenada de Bolonia (Tarifa, Cádiz; García Vargas 2010b: Fig. 14). A un nivel más fragmentario podemos encontrar Haltern 70 con estas características en Saint-Roman-en-Gal (Desbat y MartinKilcher 1989: 362, fig.4); en el oppidum de Castellas, donde han sido erróneamente clasificadas como Dressel 12 (Barberan y otros 2009: 308); en Valencia (Pascual Berlanga y Ribera i Lacomba 2001: 576); o en Valeria (González Cesteros e.p.).

El tercer grupo lo componen otros ejemplares de aspecto singular, para el que no sería descabellado proponer una explicación basada en la influencia de las ánforas del tipo Dressel 1, sin que en ningún momento las podamos considerar como reproducciones de las mismas, dadas las manifiestas diferencias formales entre ambos tipos. Además de en los fragmentos de Santarém (subgrupo VI1A) (Almeida 2008: 114, fig. 35), se pueden encontrar buenos ejemplos de esta tercera variante en Mesas do Castelinho (Fabião y Guerra 1994), siendo ambos conjuntos datables en los momentos finales de la Republica. Ya con cronología augustea, están presentes en Ampurias (Aquilué y otros 2004: 113-114; fig. 68.7), en Braga, tipo 1 (Morais 2004: 554, fig.8, $\mathrm{n}^{\circ} 18$ ), o aún en La Muette, Lyon (Desbat y Lemaître 2001: 796 y fig.8). Parece tratarse de ejemplares de la producción inicial de Haltern 70, que presentan trazos heredados de la morfología ovoide, concretamente la forma del borde, pero que en la altura de los mismos (en torno a $6 \mathrm{~cm}$ ) y en los cuellos buscan una "identidad propia" con referencias en los contenedores vinarios itálicos. (Figs. 28 y 29)

A partir de 20-15 a.C. las morfologías iniciales de Haltern 70 dan paso a una nueva generación de contenedores más estilizados, de bordes menos macizos y más esbeltos y cuellos que tienden a abandonar el perfil cilíndrico y se estrechan ligeramente en su sección central. Estas características se observan en los ejemplares de Culip VIII (figuras 29 y 30 en este trabajo), de Cartago (Freed 1996) y de La Muette, en Lyon (idem). Ésta morfología, que se fijará a partir de 20-15 a.C., es la que denominaremos Haltern 70 "clásica" augusteatiberiana (ejemplo Culip VIII o Cabrera 5) para diferenciarla de la Haltern 70 "inicial" (ejemplo Flota de 


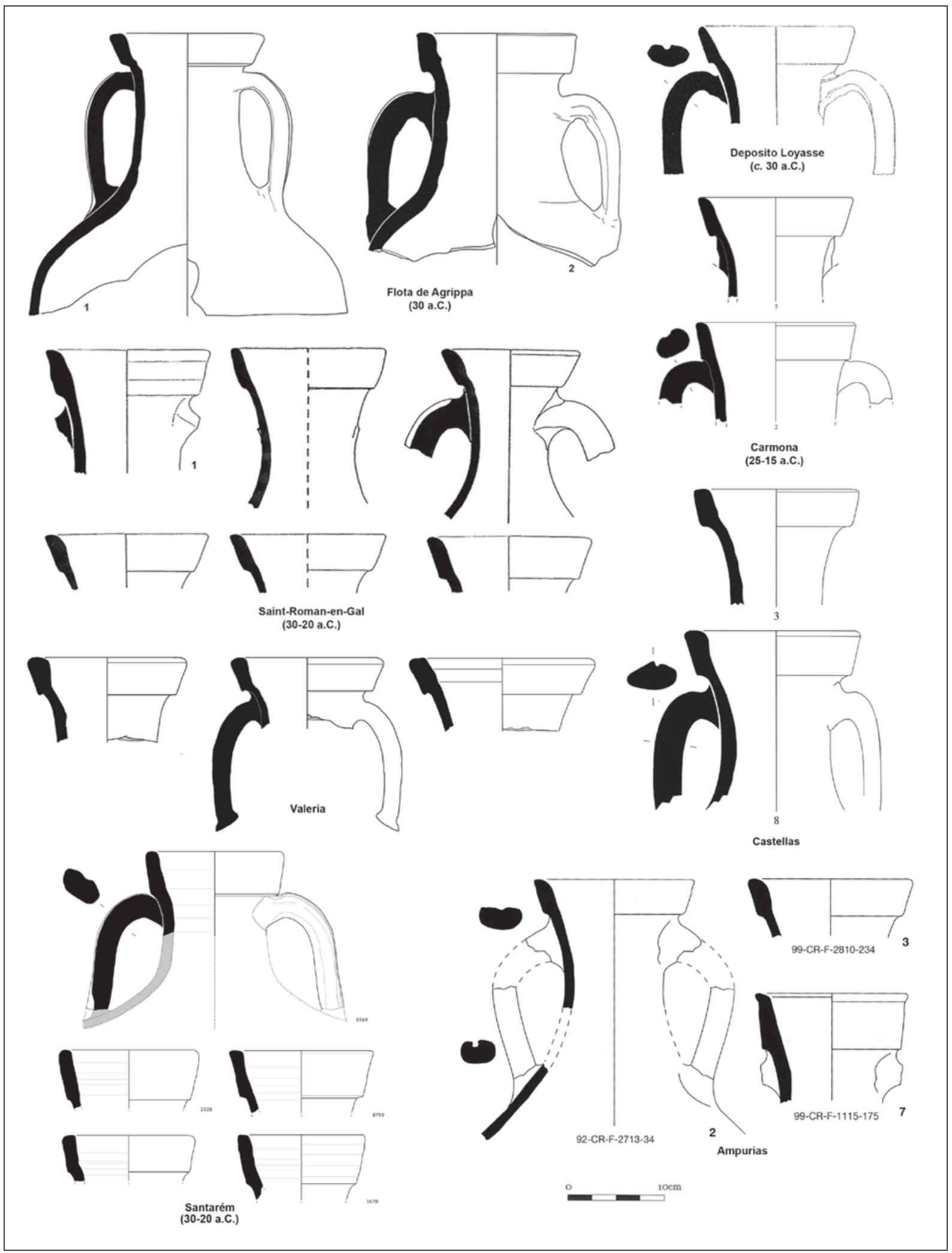

Figura 28. Ánforas "Haltern 70 iniciales". Contextos varios entre 30-15 a.C. 


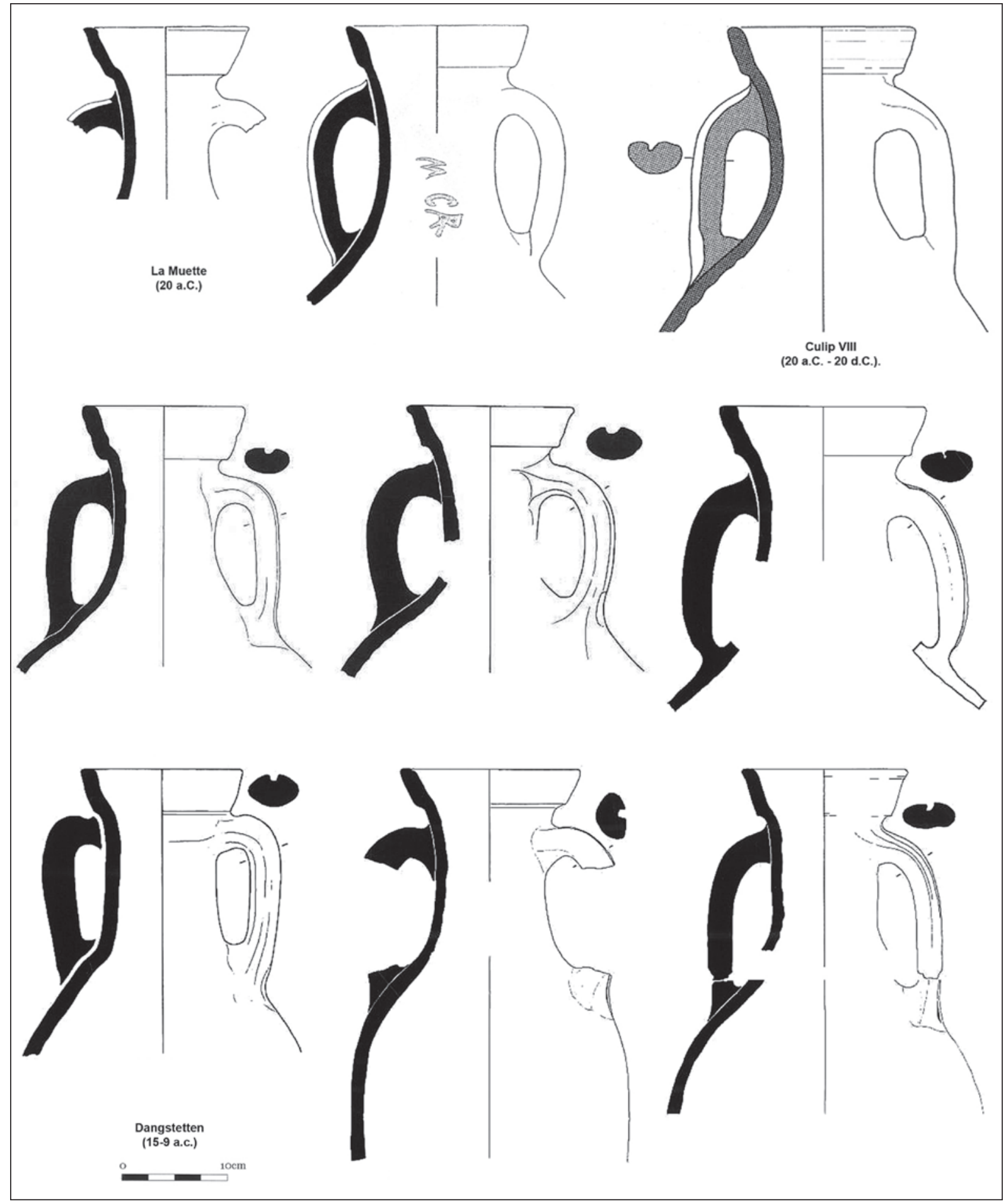

Figura 29. Ánforas Haltern 70 “iniciales” y augusteas. Contextos entre 20 y 10 a.C. 


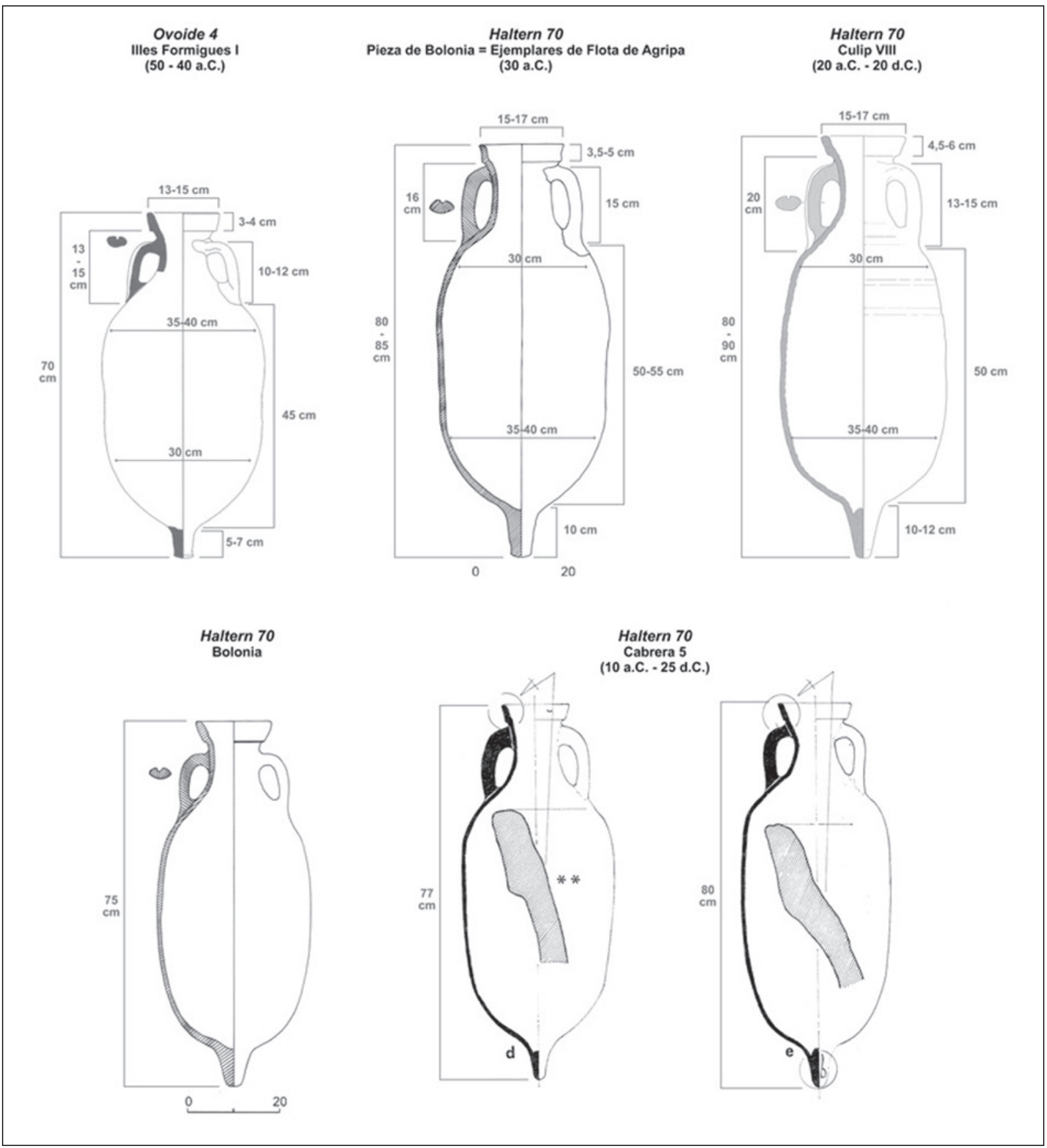

Figura 30. Comparativa de Haltern 70 del último tercio del siglo I a.C.

Agripa) y de la variante típica de época Claudia-neroniana (ejemplo Port Vendres II) que quedará claramente constituida en la década de los cuarenta del siglo I d.C. No obstante, en el campamento de Dangstetten (Baden-Württenberg, Alemania), ocupado entre el $15 \mathrm{y}$ el 9 a.C. (Fingerlin 1986; Fingerlin 1998; Ehmig 2010), a excepción de la variante más tardía, están presentes prácticamente todas las variantes antiguas de la forma, aunque con un lógico predominio de las variantes más tardías, las augusteo-tiberianas. (Fig. 30).

Antes de concluir el apartado dedicado a esta forma, queremos señalar que dentro de un conjunto 
de ánforas de la variante clásica de Haltern 70 procedentes de la prospección subacuática de las aguas de la ensenada de Bolonia (Tarifa, Cádiz) (García Vargas 2010b), apareció una pieza completa que presentaba las características habituales de las ánforas del subtipo, aunque el menor tamaño general de su cuerpo, de su cuello y de sus asas, nos ha hecho plantear la posibilidad de que se trate de un módulo menor de la forma que podría haber conservado las constantes métricas de las Haltern 70 "iniciales" o de las las Ovoide 4 (fig. 30, abajo, izquierda). Un somero estudio métrico, demuestra, no obstante, que este ejemplar se encuentra dentro de los límites inferiores de varianza de la forma, por lo que no estimamos necesario establecer una diferenciación tipológica significativa entre las Haltern 70 "clásicas" de Cala Culip VIII, entre las que pueden incluirse también las extraídas del pecio Cabrera 5, en Baleares por ejemplo (Cerdá I Juan 2000), y las similares a este ejemplar "menor" de la ensenada de Bolonia cuyas características encontramos también entre algunos ejemplares producidos en el alfar de la calle Montáchez $\mathrm{n}^{\circ} 15 \mathrm{de}$ Carmona (Gómez Saucedo e. p.).

\section{Ánforas tipo Urceus (figs. 31-32)}

A pesar de que se trata de un tipo de compleja definición que no debió de ser producido de foma generalizada en los talleres sudhispanos, hemos decidido incluirlo en el apartado dedicado a las ánforas del valle del Guadalquivir que llegaron a exportarse "masivamente", debido a que curiosamente a día de hoy la mayor parte de sus hallazgos se encuentran en ámbitos que sobrepasan en mucho el nivel local o regional. A este respecto, hay que decir, que a tenor de los datos con los que se cuenta actualmente, su principal área de difusión parece estar en la fachada atlántica peninsular (Morais 2007: 402; 2008), destacando el número de piezas en los yacimientos portugueses de Braga, Aljube (Porto) y Castelo da Lousa (Alentejo). Sin embargo, el reciente estudio del pecio de Sud-Perduto 2 en el estrecho de Bonifacio (Bernard 2008), y los datos que aquí presentamos acerca de algunos ejemplares documentados en campamentos del área del Rin, nos amplían el panorama de difusión más allá del ámbito peninsular en época augustea.

Esta forma ha sido definida hace relativamente poco tiempo, siendo Rui Morais el primero en individualizarla a tenor del material trabajado tanto en Braga (Morais 2005) como en Castelo da Lousa (Morais 2010a).
Dicha individualización ha sido plenamente positiva, poniendo de manifiesto que en el valle del Guadalquivir, al igual que aconteció en las tierras del Ródano y en el valle del Ebro, en época augustea se fabricaron envases de fondo plano con vistas a la presumible exportación de los vinos locales. Sin embargo, pensamos que aún hay que avanzar mucho para que se llegue a distinguir con mayor precisión las ánforas tipo Urceus de sus sucesoras las Dressel 28, y para poder ahondar en el conocimiento de su evolución, incluyendo los primeros estadios de su producción, probablemente a inicios del último tercio del siglo I a.C., y el momento final de la misma, que parece sobrepasar el ámbito cronológico de este estudio, llegando hasta el principado de Tiberio o Claudio. Ésta es una tarea que de momento se presenta bastante complicada, ya que en principio parecen existir varios subtipos (tal vez de carácter local o microregional), que parecen convivir en un mismo momento, siendo el caso más claro el de los ejemplares del pecio de Sud-Perduto 2 y el campamento germano de Dangstetten.

A grandes rasgos, sus principales características morfológicas serían el fondo plano o umbilicado, el cuerpo redondeado que en ocasiones presenta una especie de carena a tres cuartos de altura y un cuello corto, recto o bitrococónico, que acaba normalmente en una boca ligeramente exvasada y con un diámetro que tiende a situarse entre 14 y 18 centímetros, si bien es cierto que como indica R. Morais es bastante posible que existan varios módulos, ya que en Castelo da Lousa aparecen piezas de mucho menor tamaño (Morais 2007b: 402. Fig. A, 30-38). Con respecto a estos últimos, hay que considerar incluso la posibilidad de que se tratase de de recipientes menores, como jarros o botellas, producidos en los mismos alfares, y que viajasen junto a los contenedores de la misma forma en calidad de servicio de consumo (contenedor-"servidor").

Los labios y asas son las partes del recipiente que mayor variedad presentan, como bien puede verse en las imágenes que presenta R. Morais (2007b: 406) provenientes de distintos yacimientos del norte de Portugal y Galicia. Dentro de esta marcada heteroeneidad, tal vez puedan distinguirse tres grupos, que sin embargo no pensamos que sean exactamente los mismos que propone R.Morais (2008: 268).

El primero (tipo 1 en fig. 31) coincidiría con el grupo 1 de R. Morais, presentando un labio cuadrangular, engrosado y plano en su parte superior, que no suele llegar a los 3 centímetros de altura. El cuello parece ligeramente estrangulado en su parte inferior y las 


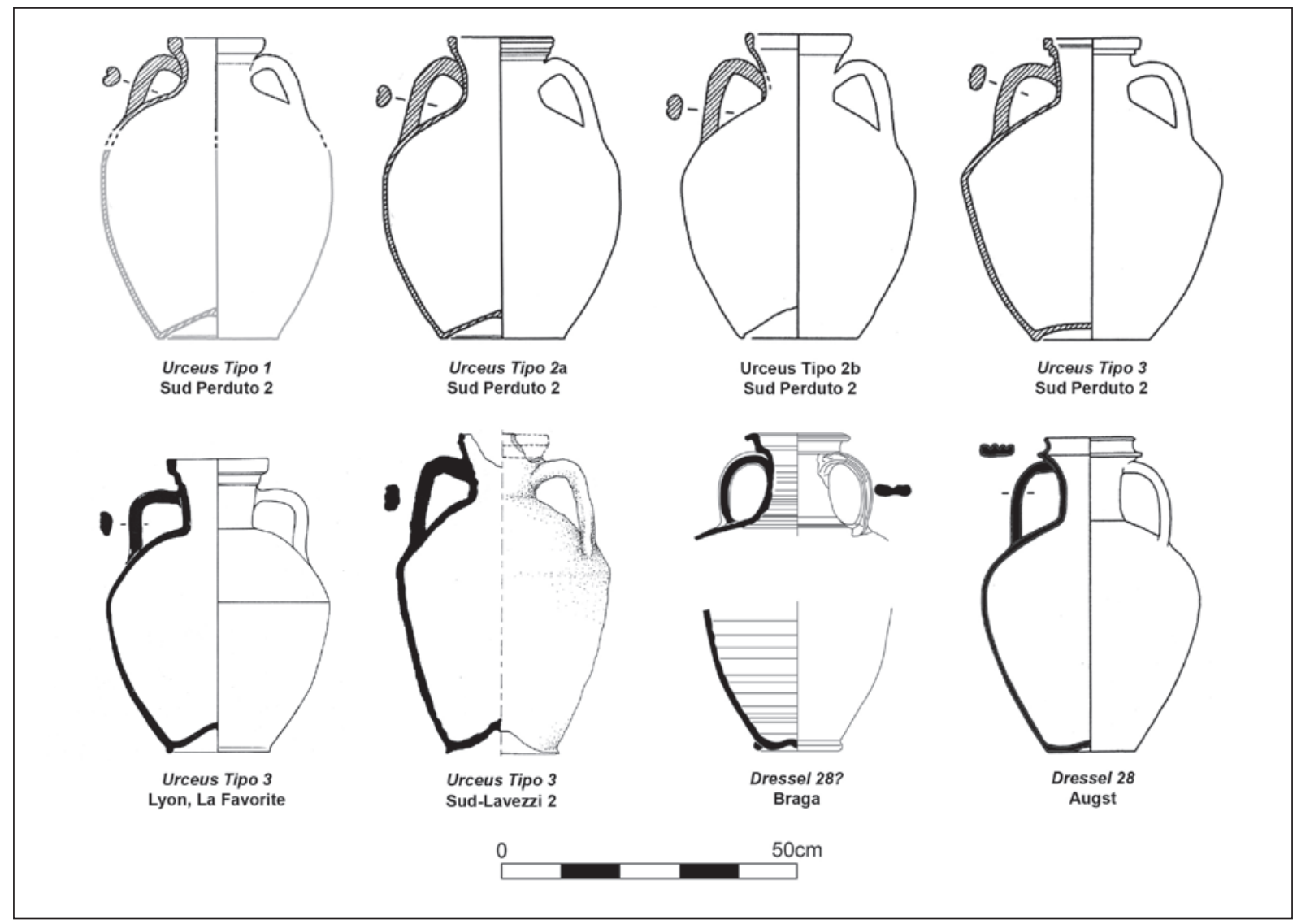

Figura 31. Ejemplares completos de Urcei y de las posteriores Dressel 28.

asas, que arrancan desde la parte media del cuello, son habitualmente de sección ovoide o rectangular y parecen mostrar un pequeño surco en su parte superior. Sería el grupo mayoritario en Braga y Castelo da Lousa (Morais2007b: 406).

El segundo grupo (tipo 2) englobaría los números 2 y 3 de R.Morais que representan dos variantes distintas. Como rasgos característicos presentaría labios más variados que están ligeramente engrosados desde la pared del cuello y que pueden estar más o menos moldurados pero por lo normal son de tendencia cóncava. Dentro de estos bordes hay algunos que presentan una serie de pequeñas acanaladuras en su parte exterior (variante A), mientras que otros son lisos (variante B). El cuello suele ser más recto y las asas similares a las anteriormente descritas. Este grupo lo encontramos en algún ejemplar en yacimientos de la fachada atlántica y en la zona productora del Guadalquivir, como los ejemplares provenientes del puerto de Hispalis (García Vargas e.p.). Sin embargo, a día de hoy contamos con mayor número de ejemplos allende la Península Ibérica, destacando la presencia de un par de piezas bien conservadas en el pecio de Sud-Perduto 2 (Bernard 2008: fig.2), y sobre todo de varios bordes y un par de fondos en Dangstetten, que U. Ehmig clasifica dentro de su forma "Dangstetten 1" (Ehmig 2010, 56 y taf.3233), si bien por las descripciones que da de la pasta y por la propia tipología, no hay duda de que se trata de urcei béticos.

El último grupo (tipo 3) es a nuestro entender el que más debió de influir en la formación de las Dresel 28, que acontece en torno a las décadas centrales del siglo I d.C. De hecho, el propio R. Morais (2008), al referirse a un ejemplar del pecio augusteo de Sud-Perduto 2 opina que ya se trata de una Dressel 28, si bien creemos que el borde y el cuerpo difieren considerablemente de los de esta última forma.

Igualmente, a día de hoy puede decirse que esta última variante es la versión que mayor homogeneidad presenta y cuenta con un número más o menos importante de piezas completas o fragmentos de buen tamaño, normalmente provenientes de contextos de fuera 
del ámbito hispano. De este modo, si bien es cierto que contamos con algún ejemplar de la región del Guadalquivir (Osset, San Juan de Aznalfarache: Vázquez Paz 2005), son los hallazgos de distintos pecios del estrecho de Bonifacio (Sud-Lavezzi 2, Lavezzi 1, Sud-Perduto 2), de la pieza prácticamente entera encontrada en el contexto lionés de Rue de la Favorite, o de las documentadas en campamentos de la frontera germana (Rödgen, Neuss, Kops Plateau en Nimega ${ }^{31}$ y tal vez en Dangstetten $^{32}$ ), los que nos dejan entrever una difusión externa de cierta importancia.

En este caso el labio presenta un característico escalón que hace que tenga dos molduras básicas (fig.31 tipo 3). El cuello es recto o ligeramente exvasado, cercano a los 18 centímetros, y las asas comienzan generalmente en la parte superior. El perfil de las asas es algo más abierto que en los casos anteriores, contando con una sección oval, que normalmente presenta dos pequeños surcos dorsales poco marcados. En los ejemplares que se conocen completos, el cuerpo presenta siempre una marcada carena en la transición del hombro hacia el cuerpo, aspecto que le confiere una morfología particular.

Como ya ha sido mencionado, el inicio de la producción de estas pequeñas ánforas parece centrarse en los momentos iniciales del principado de Augusto. De este modo, en los contextos del último tercio del siglo I a.C. de Castelo da Lousa e Hispalis ya contamos con ejemplares que se encuadran dentro de los dos primeros grupos de labios que acabamos de describir. Sin embargo, hay que destacar entre los bordes documentados en recientes excavaciones en el casco urbano de Sevilla uno de ellos (c/ Alemanes 25-27) procedente de un contexto (UE 164) datado a fines del tercer cuarto a.C., que creemos se encuadrabien dentro de nuestro tipo 2 variante $b$, siendo, por tanto, el representante más antiguo por ahora de un grupo que alcanza los años finales del siglo I a.C., como se constata, por ejemplo, en Dangsteten. Por su parte, el grupo con labio de moldura escalonada (tipo 3 ) ha sido hallado en yacimientos de carácter militar del último decenio del siglo I a.C., o el primero del I d.C, tales como Rödgen, datado entre el 11/10-8 a.C. (Schönberger y

31. Esta pieza ha sido constatada por dos de nosotros durante la campaña realizada en Julio de 2011 para la clasificación del material anfórico del yacimiento del Kops Plateau, que en breve se espera publicar conjuntamente con otros autores.

32. Entre el material presentado por Ehmig dentro del apartado de indeterminado (2010, Taf. 33), la pieza dibujada con el número1337,054-1 que cuenta igualmente con una fotografía, creemos que puede corresponderse con el borde de un Urceus de este tipo.
Simons 1976), probablemente Dangstetten (Ehmig 2010), en la primera fase del campamento del Kops Plateau de Nimega, que se enmarca entre el 12 a.C. y el 10 d.C., o en las fases augustéas de Neuss (Vegas 1975). Igualmente, en el depósito de la Rue de la Favorite en Lyon, datado groso modo en época augustea, contamos con un ejemplar cuya pasta los autores clasificaron como de posible procedencia rodia (Becker y otros 1986: 86). Este grupo parece haber pervivido durante más tiempo que el resto, ya que se encuentra entre el material de época tiberiana de Sud-Lavezzi 2 (Liou y Domergue 1990) y en el del pecio de Lavezzi 1 (Liou, 1990) que creemos ha de datarse hacia mediados del siglo I d.C. Con esta misma cronología, se conocen dos fragmentos de borde procedentes de la supuesta área de producción en el Bajo Guadalquivir. Se trata de los ejemplares de la Plaza de la Aviación de San Juan de Aznalfarache (Sevilla), la antigua Osset (Vázquez Paz 2005), asociados a TSI de época tiberiana (Consp. 18 y 37).

El desarrollo de una "familia" de ánforas con fondo plano en época temprano-augustea no nos parece un hecho casual (Carreras y González Cesteros e.p. b). El que empiecen a fabricarse de manera más o menos contemporánea en los talleres ribereños del Ebro, caso de las Oberaden 74 tarraconenses, del Ródano y su desembocadura, para las Gauloise 2, 3, 7 y tal vez 1, y del Guadalquivir en el caso de las tipo urceus, pensamos que se halla intrínsicamente ligado a la adecuación de los envases de fondo plano para el transporte fluvial en grandes barcazas de río (Carreras y González Cesteros e.p. b), descartando que se deba al temprano desarrollo de un comercio fuertemente regionalizado, casi autárquico, en las diferentes regiones occidentales del mundo romano ya en momentos augusteos ${ }^{33}$.

Con anterioridad a la aparición de las ánforas tipo urceus no está constatada la fabricación de ningún envase de fondo plano en la Ulterior, y no hay que descartar que su producción fuera debida a un influjo externo, si bien a tenor de la tipología, no creemos que se pueda establecer una línea de filiación clara. Con ello no queremos descartar que tanto las primeras ánforas galas (G.7, G.1 y sobre todo las G.2 y G.3), como las Oberaden 74 tarraconenses, pudieran haber influido

33. Pensamos que esto no es válido para el principado de Augusto, sino en todo caso para un momento tan alejado como siglo II d.C., cuando la romanización de la mayor parte de los territorios occidentales es un hecho constatado y el relativo clima de seguridad imperante incentiva la roturación de nuevas tierras y la producción agrícola. 


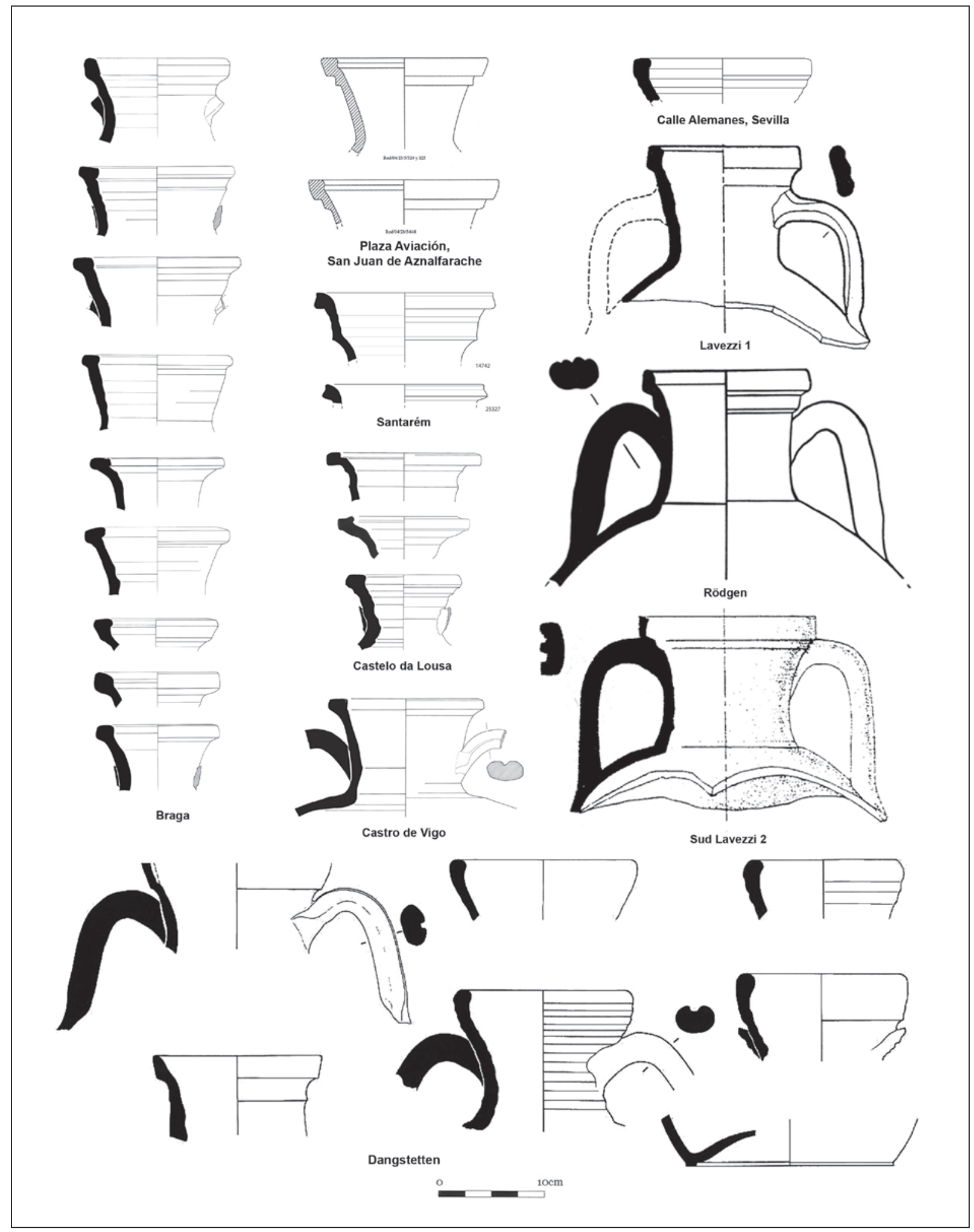

Figura 32. Ejemplares fragmentarios pertenecientes de los distintos tipos de Urcei. 


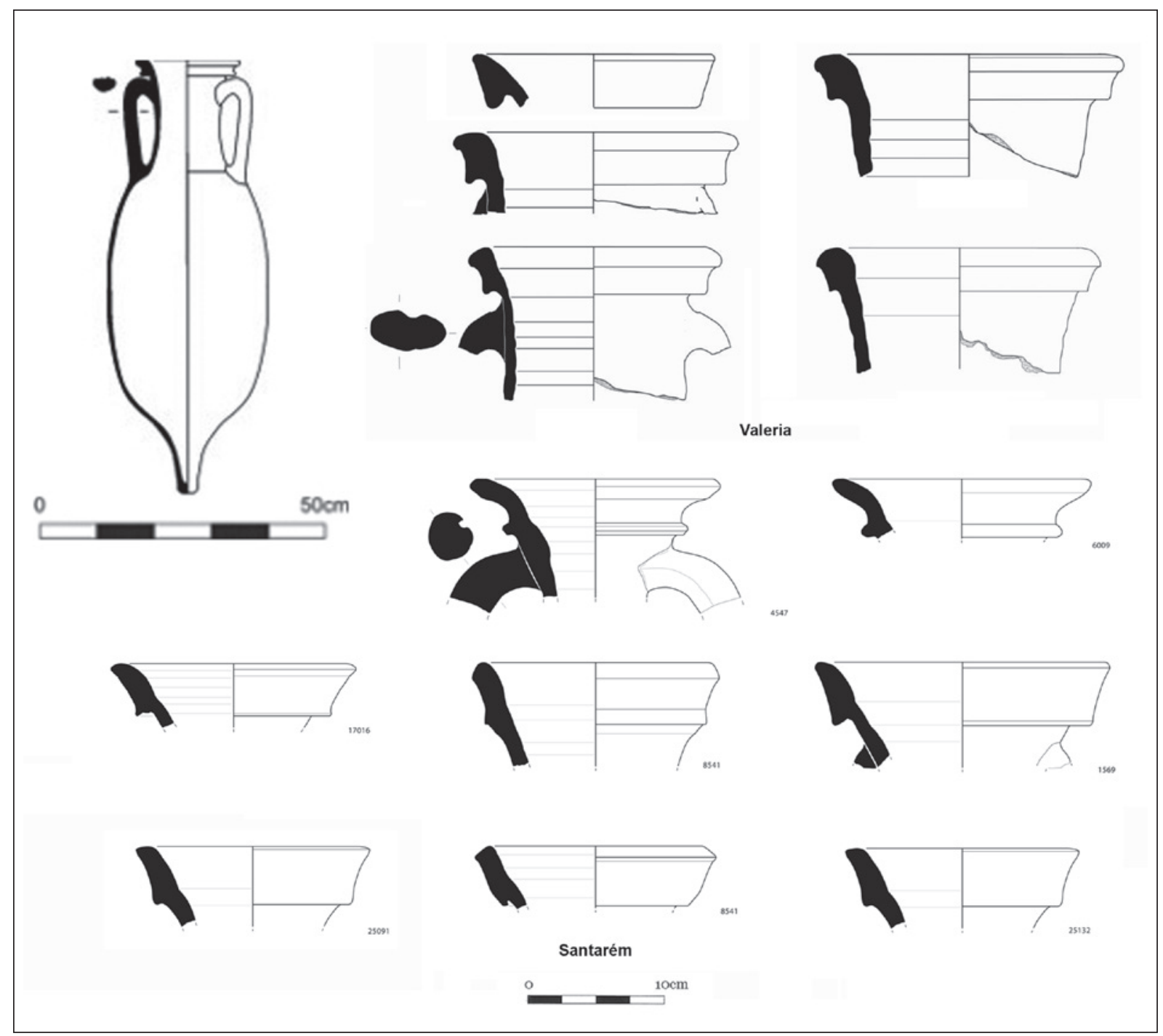

Figura 33. Prototipo y ejemplares fragmentarios atribuibles al tipo 7-11.

en la formación del modelo de ánfora plana del valle del Guadalquivir. Sin embargo, la total ausencia de esta morfología anfórica en el conjunto de la Ulterior nos lleva a plantear que, antes que la imitación de una tipología de fondo plano y posterior desarrollo de una línea de evolución tipológica, lo que acontece es más bien la adaptación de una idea surgida en las tierras del Ebro o en la desembocadura del Ródano y que se muestra perfectamente adecuada para el ámbito geográfico del Guadalquivir, donde el transporte vía fluvial es primordial.

Por último, hay que destacar que creemos que el posible nacimiento de estas tipologías en el Ebro y en el Ródano, tendría que ver en un primer momento con el impulso que provoca la presencia de tropas romanas seguido a continuación por el asentamiento de veteranos y la creación y potenciación de una red urbana de importancia en el interior de ambas regiones, que a su vez se valdría de las posibilidades del comercio que ofrecen las redes fluviales. En este sentido, en el Guadalquivir, a semejanza de los envases galos y tarraconenses, se explotarían las posibilidades de comercio fluvial, que incluso llegarían a ser sobrepasadas, exportando los vinos envasados en estos pequeños contenedores junto con el aceite y otros productos, a los mercados principales de importación, es decir, a las regiones atlánticas, los campamentos militares de Germania y la ciudad de Roma (Fig. 32). 
Formas asimilables a los tipos Dressel 7-11 (fig. 33)

Desde que C. Carreras (2001) individualizara una producción de estos típicos contenedores de la costa bética con pastas de la región de las Marismas, los investigadores comenzaron a percatarse que, efectivamente, varias habían sido las regiones en las que esta forma había sido fabricada. No es nuestra intención hacer un repaso exahustivo de un grupo de tipos anfóricos (los que se engloban habitualmente bajo el nombre Dressel 7-11 que es más bien una etiqueta para un grupo de tipos que un tipo en sí) ampliamente producidos y exportados desde el último tercio del siglo I a.C. cuyo contenido primordial fueron las salsas y conservas de pescado. Sin embargo, conviene señalar su fabricación en el valle del Guadalquivir como un tipo minoritario, pero que de la misma manera que los urcei, fue exportado siguiendo las líneas creadas por el comercio de los principales productos del Guadalquivir.

En el estado actual de nuestros conocimientos, puede afirmarse que morfológicamente no existen grandes diferencias entre las producciones costeras y las del interior, dándose por hecho que se trata de un tipo que fue inicialmente producido en los alfares situados entre la bahía de Cádiz y la desembocadura del Velez, evolucionando directamente de las ánforas "ovoides gaditanas". Este sería el razonamiento evolutivo normalmente aceptado, en el que las producciones del interior quedarían como imitaciones de unos envases que habían logrado un éxito sin precedentes en la costa. Sin embargo, los datos aportados por las excavaciones del foro de Valeria, donde apareció un pequeño lote de ánforas en un contexto del último tercio del siglo I a.C., clasificadas en un primer momento como Dressel 10-Ovoide 2 (González Cestero e.p) y que presentan pastas del bajo Guadalquivir, nos hace plantear la posibilidad de que en ambas regiones se empezaran a producir envases para las salazones contemporáneamente. Igualmente, en campamentos germanos como Oberaden, Kops Plateau, Neuss, Haltern o Anreppen, se ha podido constatar la temprana presencia de ejemplares con pastas del Guadalquivir (González Cesteros y Tremmel e.p; Carreras Monfort y González Cesteros e.p. b). Por último, dentro del mapa de dispersión de esta tipología, no podemos olvidarnos de la costa atlántica y del noreste penínsular, ya que están bien documentadas en yacimientos como Santarém (Almeida 2008), Braga (Morais 2001), Astorga (Carreras y Berni 2003) y Lugo (Carreras y Morais 2011).

De esta manera, podemos afirmar groso modo, que en época augustea, anteriormente al cambio de Era, estos envases estaban ya presentes en los mismos mercados que las ánforas olearias y las Haltern 70. Estamos convencidos que en otros muchos lugares, tales como el valle del Ródano, las costas de la Italia tirrénica, o el Levante penínsular, debieron de llegar Dressel 7-11 del interior, que han pasado desapercibidas al no hacerse distinción con las producciones costeras.

Actualmente, a tenor de las pastas documentadas, nos atrevemos a plantear que la zona de mayor producción estaría situada en torno al tramo final del Guadalquivir y las cercanías del antiguo Lacus Ligustinus. No obstante, la pasta de determinados ejemplares parece carecer de las típicas inclusiones de hematita que están presentes en los ejemplares fabricados en esa área geográfica. Ello nos induce a pensar que algunos de estos envases podrían haber portado un contenido a base de pescado de río, o en un momento determinado, otro tipo de salazones y salsas no piscícolas.

Desgraciadamente al igual que la práctica totalidad de los tipos descritos en este trabajo, en este caso tampoco se cuenta con alfares en los que se haya podido constatar su producción, lo que frena el aventurar más datos acerca de su contenido y precisar aún más su cronología.

\subsection{Los Contextos de Producción: avances en el (des)conocimiento}

Cuando en 2004 se publicaban las actas del encuentro Figlinae Ex Baetica, G. Chic García y E. García Vargas (2004: 307) constataban el absoluto desconocimiento acerca de los talleres productores de ánforas en el Bajo Guadalquivir durante la República. A ocho años vista, la situación ha mejorado relativamente, ya que, aunque todavía son escasas las noticias y las excavaciones relativas a figlinae republicanas en los ríos Guadalquivir y Genil, una serie de hallazgos parcialmente publicados aún (García Vargas 2010; García Vargas e.p.) nos ponen sobre la pista de los lugares de producción de las más antiguas ánforas de tipología romanas del valle bético.

En lo referido a las ánforas de tipología romanizada más antigua, en concreto, Dressel 1 con pastas del valle del Guadalquivir, el panorama actual viene revelando algunos datos escasos pero bastante novedosos, que certifican la manufactura inequívoca en la región de imitaciones de esta forma de origen itálico. Se conoce (García Vargas e.p.), un tercio superior, sin asas, de un ejemplar de Dressel 1 del Guadalquivir procedente de hallazgo superficial en el alfar de Guadalbaida 
o Dehesa de Arriba en Posadas (Córdoba), la figlina Trebeciana de CIL XV, 3814 (cf. Berni Millet 2008: 483). Esta alfarería, situada a la salida de la población actual de Posadas (la antigua Detumo), aguas abajo de Córdoba, produjo ánforas Dressel 20 con seguridad desde mediados del siglo I hasta el siglo III d. C., conociéndose para la segunda mitad del siglo I d. C. una producción, con sellos propios de este taller, de ánforas vinarias del tipo Dressel 2-4 provinciales (García Vargas 2004a; 2004b). Esto parece sugerir la posibilidad de que en fases anteriores a las documentadas en superficie, la misma figlina produjera contenedores vinarios, aunque el fragmento de Dressel 1 mencionado no es un defecto de cocción y, obviamente, no tiene por qué ser necesariamente una producción local.

En cualquier caso, el perfil de esta Dressel 1 ¿A? de la Dehesa de Arriba que conocemos gracias a la amabilidad de Juan Solís (q.e.p.d.), se asemeja a lo del ejemplar completo publicado como procedente del poblado minero de La Loba (Fuenteovejuna, Córdoba, Benquet y Olmer 2002: 150a) en el tamaño reducido de la pieza y en el borde corto que, sin embargo es morfológicamente diferente (supra). Los contextos de La Loba se fechan en las primeras décadas del siglo I a.C., momento en el que en la ciudad de Sevilla ya se reciben ánforas locales de imitación de la forma Dressel 1A, razón por la que se ha propuesto (García Vargas 2010; García Vargas e.p.) una fecha dentro de la primera mitad del siglo I a.C. para las Dressel 1 regionales como las que, supuestamente, debieron ser fabricadas en la Dehesa de Arriba.

La ciudad de Posadas se encuentra unos $100 \mathrm{~km}$ al sur de Fuenteovejuna y está relativamente bien conectada por tierra con las mineralizaciones de las Subbéticas cordobesas, estribaciones a las que pertenece Fuenteovejuna, de modo que no es difícil pensar que algunos alfares del curso medio del Guadalquivir comenzaran a producir ánforas vinarias para el abastecimiento minero en un momento (primeras décadas del siglo I a.C.) en que éste estaba aún dominado por las ánforas itálicas, como muestran los contextos de La Loba. Nada hay seguro, sin embargo, al respecto, excepto el hecho de que ésta es la fecha también en que las Dressel 1 locales aparecen en otros contextos de consumo de la región, como la portuaria Sevilla (supra), lo que indica una cierta infraestructura productiva ya en estas fechas iniciales.

Por desgracia, y aunque los contextos de consumo evidencian la progresiva expansión de la distribución comercial de las ánforas del Guadalquivir a lo largo del segundo tercio del siglo I a.C., (García Vargas e.p.) no volvemos a tener evidencias de producciones locales en talleres del Bajo Guadalquivir hasta los años iniciales del principado de Augusto, momento en el que en la ciudad de Carmo, la actual Carmona, posee en su zona periurbana, sobre la Vía Augusta y a la salida de la puerta occidental de su muralla (actual Puerta de Sevilla), un conjunto de talleres que se han ido excavando en los últimos 25 años $^{34}$ y que actualmente se encuentran en curso de publicación (algunas noticias en García Vargas 2010 y García Vargas e.p.). En general, las evidencias de producción cerámica (incluidas ánforas) de este sector occidental extramuros de Carmona se datan por el material cerámico entre 30 a.C. y 50 d.C., produciéndose con seguridad en los hornos aquí excavados ánforas de las formas Pellicer D, Ovoide 4, Ovoide 6, Tipo 10, Haltern "iniciales" 70 y Haltern 70 "clásicas" augusteo-tiberianas.

En otras localidades del valle del Guadalquivir como Ilipa (Alcalá del Río, Sevilla), aunque los contextos de amortización indican la presencia de ánforas de tipología preimperial o tempranoaugusteas en lugares como calle Santa Verania, con Ovoide 4 y Haltern 70 (Cervera Pozo y otros 2007: 307-308) o la fosa de fundación de la muralla romana en la excavación del Pasaje Real (Izquierdo de Montes 2007: 202, fig. 14, con Ovoide 4, T. 7.4.3.3 gaditanas y LC 67), los escasos contextos de producción conocidos corresponden ya a época tardoaugustea, cuando no tiberiana (calle Mesones 40-44: García Vargas 2010b, fig. 13).

Ninguna evidencia material más puede señalarse hoy por hoy acerca de los centros de producción de las ánforas republicanas del Guadalquivir. Allí donde se ha documentado unos inicios relativamente antiguos de la producción rural de ánforas, como en Las Delicias (Écija: Sáez Fernández y otros 1997) o en La Catria (Remesal Rodríguez 1977-1978; Chic García 2001), Sevilla ( García Vargas 2003, a partir de material residual en un área de alfar de la segunda mitad del siglo I d. C.), los testimonios iniciales de la producción no van nunca más allá de época tiberiana o claudia (Cf. García Vargas 2010b). Esta es también la fecha en la que se documenta el inicio de la práctica de sellado sistemático de los contenedores, de manera que cabe preguntarse si existe una relación más o menos directa entre la práctica del sellado en las ánforas y los inicios de la “industrialización” de su producción con la apertura de los grandes talleres rurales como Las Delicias o La Catria, por poner sólo dos ejemplos bien conocidos.

34. Cf. Rodríguez Rodríguez 2001 para una publicacion de síntesis. Vide también Gil de los Reyes y otros 1987; Cardenete y otros 1989; Gómez Saucedo e.p.; Conlin y Ortiz Navarrete e. p.). 
Con anterioridad a 30-50 d.C. sólo se conocen de momento producciones suburbanas como las de Carmona que, además, presentan la particularidad de no estar dedicadas en exclusiva a la producción de ánforas y de que las ánforas que fabrican no son en todos los casos de tipología romana. En los talleres más antiguos de Carmona, las Haltern 70 de morfología tempranoaugustea conviven con ánforas Pellicer D producidas aún en cantidad similar o ligeramente superior a la de las ánforas de tipología romanizada. Por su parte, la producción no anfórica en los talleres de Carmona es en buena medida una producción de morfología tardoturdetana, con predominio de urnas pintadas, cuencoslucerna, platos con líneas pintadas o lisos y lebrillos, a veces decorados estos últimos con pintura roja al interior reproduciendo líneas onduladas perpendiculares al borde o retículas formadas por líneas rojas en el interior del recipiente.

La producción tardorrepublicana y tempranoaugustea, al menos en Carmona, muestras, pues, escasas evidencias de "especialización", lo que en parte puede deberse al carácter excéntrico de los talleres carmoneses con respecto a los grandes ejes fluviales, como el Guadalquivir y en parte al hecho de que la gran eclosión exportadora de las ánforas del Guadalquivir hacia la Galia y el limes reno-danubiano es algo posterior a las fechas de plena actividad de los alfares suburbanos de Carmona. Hacia 50 d.C., la actividad en las figlinae carmonenses ha desaparecido casi totalmente y no será hasta época flavia cuando comiencen a producir en cantidad "industrial" las alfarerías de la desembocadura del Corbones, a unos $15 \mathrm{~km}$. al norte de Carmona, pero aún en el área de influencia inmediata de la ciudad. Es sellado es ya habitual en estas producciones del Corbones, lo que, junto al elemento POR(tus?) denota una actividad alfarera volcada totalmente a la exportación masiva de ánforas olearias del tipo Dressel 20 (Chic García 2001).

\section{EL VALLE DEL GUADALQUIVIR VERSUS OTRAS REGIONES ALFARERAS HISPÁNICAS. PROBLEMAS EN EL ESTUDIO DE UN UNIVERSO COMPUESTO POR DIFERENTES REALIDADES (A VECES COINCIDENTES...).}

En este amplio artículo hemos intentado dar un paso más para rescatar del anonimato a la producción de envases cerámicos destinados a la exportación de los bienes agropecuarios del valle del Guadalquivir en época tardorrepublicana y augustea. Por lo tanto, lo que pretendemos es presentar una nueva herramienta de base, o mejor dicho una herramienta actualizada, que nos pueda servir (en primera instancia a los especialistas "hispanos", los que más probabilidades tenemos de encontrarnos con este tipo de evidencia, pero igualmente, a sabiendas que el carácter actual de su dispersión empieza a mostrarnos la importancia que puede tener para la investigación en otros ámbitos geográficos) para ahondar en el conocimiento de la economía y sociedad de este área geográfica y de las regiones que importaron sus productos.

Sin embargo, consideramos que sería un error no echar cuanto menos un vistazo a las evidencias históricas y arqueológicas que nos presentan otros territorios peninsulares en este mismo periodo, ya que podemos afirmar que en el marco del comercio en la Antigüedad, donde el ir y venir de personas y mercancías era constante (cuanto menos en el final de la República y los dos primeros siglos de nuestra era), en rara ocasión las ideas se desarrollaban en un único lugar al margen de la influencia externa.

En estos momentos tardorrepublicanos en todas las regiones costeras mediterráneas y en la zona atlántica meridional de la Península Ibérica, al igual que en el valle del Guadalquivir, asistimos a un proceso de influencia y colonización itálica efectiva, que lleva a que la producción agropecuaria y la ordenación del territorio empiecen a regirse por patrones de tipo itálico. De este modo, la orientación de la explotación de los recursos de la tierra y el mar estará marcada por una producción intensiva con vistas a la exportación de sus excedentes, que irán dirigidos principalmente a unos consumidores de origen o costumbres romano-itálicas. Ello tiene evidentemente su reflejo en los envases destinados a la exportación de estos excedentes, creándose un universo formal que tiene como modelo a los contenedores itálicos más difundidos del momento, que en una primera etapa son literalmente copiados, pero que pronto adquirirán en cada región un marcado carácter local, fruto de las tradiciones alfareras precedentes.

El caso de las tipologías ovoides es muy ilustrativo, ya que a pesar de ser el valle del Guadalquivir donde mayor relevancia tuvieron, también fueron fabricadas en otras regiones sudhispánicas, e incluso en el noreste peninsular o en la costa occidental de la Lusitania. Este hecho resulta en ocasiones problemático para la investigación arqueológica, ya que parece que un mismo tipo fue fabricado en distintas regiones -caso de las Ovoide 1 (Lomba do Canho 67), de las Haltern 70, o de los distintos tipos de ánforas olearias, e igualmente es posible que ánforas como las Ovoide 4 hayan podido 
producirse en alfares de ámbitos geográficos distantes, o cuanto menos que se hayan alcanzado soluciones formales muy similares para el envasado de productos similares- lo que puede llevar a confusiones entre ellos y a imprecisiones a la hora de determinar la importancia de las exportaciones de cada zona.

En este apartado, hemos decidido centrarnos en las demás regiones hispanas, principalmente la costa bética y la Tarraconense nororiental, sin duda alguna las áreas más activas en época tardorrepublicana y augustea, al margen del Baetis, pero sin olvidarnos de la emergente Lusitania occidental. La Bética costera con sus distintas áreas productoras comparte una serie de características comunes con el valle del Guadalquivir, ya que en cierta medida se trata de la zona natural de salida de sus productos por vía marítima. La segunda de ellas, el litoral del noreste peninsular, es bastante más distante y presenta una tradición prerromana bien distinta, por lo que creemos que es de gran interés observar la evolución de una y otra al amparo del influjo romanizador y ver su reflejo en el repertorio anfórico. La Lusitania, cuenta actualmente con un volumen de información bastante menor, pero que empieza a mostrar las primeras señales de que podría haber desarrollado un proceso similar, aunque a una escala aparentemente más reducida.

\subsection{La Costa Bética: bahía gaditana, bahía de Algeciras y litoral malacitano}

\subsubsection{Bahía de Cádiz.}

No resulta fácil realizar una síntesis de la producción de ánforas en la bahía de Cádiz y las costas del Estrecho durante los años finales de la República romana, dada la complejidad en estos momentos de la evolución formal de las mismas. En efecto, desde antes del fin del siglo II a.C., una serie de influencias morfológicas de diversas procedencias comenzarán a transformar lentamente las formas de hacer del artesanado cerámico local, hondamente arraigadas en las tradiciones alfareras semitas occidentales (Ferrer Albelda y García Fernández 2008). La alfarería tardopúnica del sur de Iberia fue, pues, una suma de tradiciones que se superpusieron casi de forma estratigráfica y que afectaron también a los territorios mauritanos, extendidos, entre el Mediterráneo y el Atlántico, al otro lado del estrecho de Gibraltar (Aranegui Gascó y otros 2004). Puede hablarse entonces de un repertorio anfórico propio y común a todos los enclaves púnicos del Círculo del Estrecho en el que, a partir de finales del siglo II / inicios del siglo I a.C., va adquiriendo un peso creciente el factor itálico.

Desde el tercer cuarto del siglo II a.C., dos nuevas series de contenedores, las ánforas T.7.4.3.2/7.4.3.3 y las imitaciones de ánforas Dressel 1 , sobre todo de la variante $\mathrm{C}$, van imponiéndose sobre el resto de los grupos morfológicos aún en circulación, la casi totalidad de los cuales estaba integrada por formas de más antiguo origen (series: T.12.1.1.0 y T. 9.1.1.1: Sáez Romero 2008). Este será el punto de partida para la gran transformación de la morfología general de los contenedores gaditanos que procederá según una serie de fases crono-tipológicas que pueden resumirse del siguiente modo (cf. Sáez Romero 2008: 517).

\section{A) Ánforas gadiritas de transición entre el mundo púnico occidental y el tardopúnico en vías de romanización (140/30-80/70 a.C.).}

Las ánforas neopúnicas gaditanas del tipo 7.4.3.3 o Mañá C2b son viejas conocidas de la Arqueología tardorrepublicana en Occidente (cf. Mañá 1951), dada su enorme difusión entre el último tercio del siglo II a.C. y los años iniciales del principado de Augusto (Ramón Torres 1994: 635, mapa 83). Se trata de una versión local, relativamente fiel al original, de las ánforas púnicas de Cartago del tipo Mañá C2b o 7.4.2.1/7.4.3.1, de las que surgen a través de una primera imitación occidental denominada 7.4.3.2. (Ramón Torres 1994: 212). Ésta última se interpreta más bien hoy, sin embargo, como una variante contemporánea del tipo más habitual, razón por lo que se comienza a hablar de ambos tipos como una sola forma con la denominación 7.4.3.2/7.4.3.3 (Sáez Romero 2008: 566). En cualquier caso, el protagonismo de las 7.4.3.3. es evidente desde principios del siglo I a.C., habiéndose señalado dos grandes fases productivas. La primera de ellas ocuparía desde los inicios de la producción hacia 140-130 a.C. hasta 80/70 a.C., y la segunda desde estas fechas hasta 40-30 a.C. En ambas fases se produjeron contenedores de morfología muy similar, aunque, como es lógico, con variaciones formales apreciables entre un momento y otro (Sáez Romero 2008: 567-569), aunque, quizás, lo más interesante desde el punto de vista general de la estructura de la producción es que pequeños cambios en la morfología de las variantes de este contenedor se asocian a esquemas productivos específicos: "suburbana" y concentrada en la primera fase, y dispersa en establecimientos rurales en las campiñas gaditanas durante la segunda fase de producción. 
Las imitaciones de contenedores extrapeninsulares no resultó ninguna novedad en los talleres púnicos gaditanos después de la conquista romana. Imitaciones de contenedores de tradición griega, como las ánforas "marsellesas" fabricadas en Campo Soto en el siglo VI a.C. fueron relativamente frecuentes en los alfares insulares gadiritas, incluso antes de la presencia romana efectiva. Se documenta así en la segunda mitad del siglo III a.C. una serie amplia de ánforas Grecoitálicas de morfología antigua, tipo Will A, Adria 3-4 o MSG V (Sáez Romero 2008: 573), a las que sigue hacia fines de este siglo y comienzos del II a.C. las imitaciones de las series “clásicas” de Grecoitálicas Will C-D, Adria 5-7 o MSG V-VI (Idem: 574. Cf. García Vargas 1998: 69-71) y, ya en el segundo cuarto del siglo II a.C. las Grecoitálicas "evolucionadas", o de transición entre las Grecoitálicas finales (Will E o MSG VI) y Dressel 1A que perduran probablemente hasta fines del siglo II (Sáez Romero 2008: 574).

\section{B) Primer horizonte de romanización de la morfología anfórica gaditana (80/70-40/30 a.C.)}

Por encima del carácter tradicional o novedoso de las imitaciones de formas itálicas en la alfarería tardopúnica gaditana, merece la pena señalar que los cambios en los modelos de implantación de los talleres, consecuencia sin duda de nuevas realidades territoriales en la Bahía, ponen de manifiesto una efectiva "romanización" de las estructuras de producción anfórica que ya fue apreciada hace unos años (García Vargas 1996). Ésta nueva fase, más romanizada, de la producción está sin embargo presidida por la variante reciente de los contenedores púnicos del tipo 7.4.3.3., caracterizados por un cuello algo más esbelto que sus predecesores y un labio más colgante y moldurado. A ellos, se asocian sistemáticamente las imitaciones de ánforas de tipología itálica que reproducen, con bastante fidelidad, el perfil de las Dressel 1 C. La mayoría de los talleres que produjeron estas formas se conocen sólo por prospección (Lagóstena Barrios 1996a y b; García Vargas 1998), pero, en general, se adivina un horizonte que se hace visible en los decenios iniciales del siglo I a.C. y que incluye las ánforas de tipología ovoide (Ovoides gaditanas), las primeras Dressel 12, que en ocasiones no es fácil distinguirlas de las Dressel $1 \mathrm{C}$ y, aparentemente, también las series gaditanas de las ánforas del tipo Lomba do Canho / LC 67.

En este mismo contexto productivo empiezan a aparecer las denominadas "ánforas ovoides gaditanas", un tipo de envases aún por sistematizar de manera precisa, pero que ponen de manifiesto la existencia en los alfares costeros de un proceso evolutivo muy similar al que acontece en el valle del Guadalquivir, resaltando el estrecho vínculo entre una y otra zona, que se manifiesta no sólo en la producción de un mismo tipo de ánforas en los talleres de uno u otro ámbito, sino en la influencia de unos mismos modelos extrapeninsulares dentro del repertorio tipológico, que en este caso se plasma por medio de las ánforas de forma ovoide del sur de Italia, pero también de las Dressel 1 tirrénicas.

No obstante, hay que resaltar las diferentes adaptaciones que de estos prototipos itálicos se efectúan en uno u otro lugar, y que a nuestro modo de ver han de ponerse en relación con las diferentes orientaciones de la economía agropecuaria de cada espacio geográfico, primando el vino y el aceite en el interior y las salsas y salazones de pescado en la costa. Este sería el motivo por el que, mientras que en el Guadalquivir las producciones de Dressel 1 tendrían a las variantes A y B como su principal referente, en el ámbito costero, habiéndose producido igualmente estes subtipos (García Vargas y Bernal Casasola 2008: 664-668), son la Dressel $1 \mathrm{~A}^{35} \mathrm{y}$ sobre todo la $\mathrm{C}$ las que en mayor número parecen haber sido fabricadas. La mayor producción de Dressel 1C en el ámbito costero bético podría estar determinada por la utilización de esta tipología como envase para pescado en la propia Italia, como parece indicar la alta presencia de Dressel 1C de producción local aparecidas en las excavaciones de la pesquería y puerto de Cosa (McCan 1987: 201-204). Igualmente, las producciones ovoides gaditanas parecen adaptar las formas al contenido salazonero, teniendo por lo general bocas más exvasadas, cuellos habitualmente algo más anchos, asas más cortas y pivotes huecos, haciendo posible una más fácil extracción de un contenido que suele ser en gran parte sólido (trozos de pescado en salazón o salmuera) o semisólido (salsas que debían ser frecuentemente gelatinosas).

Estas primeras series gaditanas de morfología romanizada comparecen en cargamentos como los de los pecios Titán, Grand Conglué C, Cap Bear, Illes Formigues I y Cala Bona I, así como en yacimientos terrestres

35. En los últimos años, han aparecido una serie de contenedores con pastas gaditanas y con restos de pescado en su interior en Baelo Claudia (Arévalo y Bernal Casasola, cord. 2007). Ello que testificaría la utilización en el ámbito costero sudhispano para el envasado de productos piscícolas, de una tipología que, si bien es bastante variable morfológicamente (Tchernia 1986: 312-320) y podría haber portado múltiples contenidos, generalmente suele ser asociada a la exportación de vino. 
en Fréjus (Goudineau y Brentchaloff 2009), Cartago (Martin-Kilcher 1993), Toulouse (Benquet y Grizeaud 2009) o Petrisberg (Trier, Alemania).

En estos lugares no parecen acompañarlas las Dressel $1 \mathrm{C}$ locales y las 7.4.3.3, lo cual es bastante significativo pues parece indicarnos que habitualmente no fueron exportadas de forma conjunta. Sin embargo, los alfares del entorno de la desembocadura del río Guadalete, muestran sistemáticamente, la producción de ánforas "neopúnicas" y "romanizadas" al mismo tiempo. Lo mismo sucede con los escasos talleres suburbanos, como el de la Calle Gregorio Marañón o el de la Avenida de Portugal, en Cádiz, y el de la calle Javier de Burgos de El Puerto de Santa María, una aglomeración rural cuyos orígenes se sitúan en un momento indeterminado del siglo II a.C., probablemente en su segunda mitad. Por su parte, los pocos contextos de consumo bien fechados en el Bajo Guadalquivir, como los de Sevilla (calles Argote de Molina y Patio de Banderas: Campos Carrasco 1986; García Vargas 2009; García Vargas e.p.) están repletos de ánforas gaditanas del tipo 7.4.3.3 desde fines del siglo II a. C., siendo especialmente abundantes en el tercio central del siglo I a.C. y perdurando, aparentemente, hasta época augustea inicial. Esta misma asociación de contenedores de éxito de producción gaditana es la que circula a partir de mediados de la centuria a los contextos de la fachada atlántica, pudiéndose apuntar Castro Marim (Viegas 2011), Faro (Viegas 2011), Mesas do Castelinho (Parreira 2009) o Santarém (Arruda y Almeida 1998; Almeida 2008) como algunos de los casos mejor estudiados y más emblemáticos.

\section{C) Horizonte de "cristalización" del}

repertorio anfórico tempranoimperial

gaditano (40/20 a.C.-10/20 d.C.)

Hacia fines del siglo I a.C. (40/30 a.C.) hace su aparición en la bahía de Cádiz un conjunto de tipos anfóricos de morfología romanizada que no constituyen ya imitaciones directas de ánforas itálicas, aunque sí deben estar inspiradas en las últimas series republicanas tirrenas y adriáticas. Se trata de la conocida familia de las Dressel 7-11 cuyos ejemplares de morfología más antigua hasta ahora conocidos proceden de los alfares de San Fernando (Gallineras, Cerro de los Mártires)(cf. García Vargas 1998). En un primer momento, se fabrican exclusivamente las formas Dressel 7, 9 y 10. La Dressel 9 y 10 derivan directamente de las ánforas denominadas Ovoides gaditanas o Dressel 10 arcaicas, propias de la fase anterior, mientras que en la constitución del tipo Dressel 7 deben haber intervenido diversas influencias formales, entre las que la de las Dressel 1 y las Lamboglia 2 parecen haber sido las más importantes. $\mathrm{Su}$ ámbito de producción mayoritaria es el mismo que para el grupo anterior: talleres rurales que, sin embargo, no se limitan ahora a las campiñas de la desembocadura del Guadalete y a los talleres suburbanos de la ciudad de Cádiz, sino que se extienden también de manera súbita a las campiñas interiores de los actuales términos de Chiclana, Puerto real y Jerez de la Frontera donde su manufactura aparece en parte ligada a explotaciones rurales del tipo villa, en parte a centros alfareros aparentemente independientes en torno a afloramientos arcillosos importantes, como ocurre en el entorno de Cerro de Ceuta (Puerto Real).

De los tipos del período anterior sólo la Dressel 12 sobrevive sin grandes cambios morfológicos aunque presenta un cuello que ha perdido ya la moldura medial característica de los ejemplares tardorrepublicanos y desarrolla grandes bocas con bordes rectos y escasamente moldurados. Se trata de la primera serie de ánforas gaditanas con pivote macizo, un detalle morfológico ajeno por completo a la tradición local, por lo que se supone una conexión directa entre las últimas Dressel 1C y las primeras Dressel 12. Hasta el punto de que R. Etienne y F. Mayet (1995) propusieron considerar a las Dressel 1C gaditanas como Dressel 12 arcaicas. Resulta tentador trazar una línea evolutiva ininterrumpida entre las "Dressel 12 arcaicas" tardorrepublicanas de la primera mitad del siglo I a.C. y las Dressel 12 "terminales" de fines del siglo II - principios del III d. C. de Puente Melchor (Puerto Real Cádiz: García Vargas 1998: fig. 57.2-4 y 58.1-2), pero basta un examen atento de las características morfológicas de las Dressel $1 \mathrm{C}$ del alfar de la calle Gregorio Marañón, que imitan hasta en sus más pequeños detalles la morfología de sus homólogas tirrénicas, o de las Dressel 1A del depósito de fines del siglo II a.C. de la ciudad de Baelo Claudia (Arévalo González y Bernal Casasola 2007; Bernal Casasola y otros 2003) para advertir que estas ánforas Dressel 1 imitadas forman parte de la vieja tradición gadirita de producir series de imitación junto a las de morfología tradicional en la región y que esta "tradición" se va a alargar en el tiempo hasta al menos mediados del siglo I a.C., un momento en el que las Dressel 1 B y C del alfar de la calle Javier de Burgos de El Puerto de Santa María mantienen los rasgos generales que permiten que las reconozcamos como Dressel 1 en un momento en el que, si hemos de confiar en los pecios, las Dressel 12 se encuentran totalmente formadas. 
No vamos a entrar en la polémica acerca de la existencia de una serie de Dressel 12 del valle del Guadalquivir, ni en la de los contenidos prioritarios de las Dressel 1 gaditanas, pero, en cualquier caso, la presencia en esta región interior del Guadalquivir de una serie de Dressel 1 imitadas que desaparece sin dar paso a una producción, al menos numerosa, de Dressel 12, parece ofrecer un argumento adicional para sostener que las imitaciones de Dressel 1 (como las que hemos apuntado supra de Lamboglia 2) constituyen un "episodio morfológico" con entidad propia en el sur de Hispania, sin que sea conveniente diluirlo en el seno de una producción regional, como la de las Dressel 12 , conceptualmente diferente a pesar de las conexiones entre ambas formas. También las Dressel 8 que no hacen su aparición hasta época medio-augustea (García Vargas 2001: 77) o augustea tardía (García Vargas 2010b: 590 presentan una serie de concomitancias formales con las 7.4.3.3., incluso en la articulada molduración del borde, sin que parezca lícito denominar a las primeras Dressel 8 iniciales o arcaicas. Aunque la línea de continuidad entre las Ovoides gaditanas y las Dressel 10 es mucho más directa, preferimos mantener la primer denominación en preferencia de Dressel 10 arcaicas para las primeras por razones que en este caso no son tan directamente formales, como conceptuales (conexión con el fenómeno hispano de las series ovoides tardorrepublicanas) y económicas (pertenencia a unas estructuras de producción y distribución ciertamente diferentes), como la incipiente epigrafía sobre Dressel 7-11 (sellos y tituli) se encarga, por otra parte de certificar.

\subsubsection{Bahía de Algeciras y costa del Estrecho}

Las ánforas republicanas de la costa del Estrecho y la bahía de Algeciras presentan una situación paradójica desde el punto de vista de su conocimiento científico: por una parte fue precisamente en el entorno del Estrecho donde por primera vez se propuso y definió la existencia de series regionales de imitación de ánforas itálicas (infra); al mismo tiempo, ha sido en esta zona donde más dudas y dificultades se han mantenido a la hora de definir el carácter de las producciones detectadas y, sobre todo, su cronología exacta (cf. Bernal Casasola y Jiménez-Camino Álvarez 2004).

Después de la publicación por parte de $\mathrm{Cl}$. Domergue (1969: 449; 1973: 114) de los ejemplares de Dressel 1C y de Dressel i21-22? de fabricación local documentados en los sondeos realizados por la Casa de
Velazquez en la ciudad romana de Baelo Claudia, en plena costa del Estrecho de Gibraltar, se asumió, como se ha indicado, una manufactura local de estas producciones, con una cronología genérica de segunda mitad del siglo I a.C. Aunque Cl. Domergue propuso un origen en la propia Baelo para estas imitaciones locales de ánforas itálicas, lo cierto es que la publicación casi simultánea de unos hornos de ánforas en la playa de El Rinconcillo (Algeciras, Cádiz) entre cuyas producciones se contaban ánforas de la serie "clásica" de los contenedores salsarios sudhispanos (Dressel 7-11 y Dressel 12) con elementos epigráficos similares a los documentados sobre las ánforas republicanas de Baelo y, lo que es más importante, cuellos de Dressel 1C virtualmente idénticos a los de Baelo (Sotomayor Muro 1969), hizo razonable una producción de estos contenedores en el Rinconcillo y su exportación a la relativamente cercana ciudad de Baelo Claudia (cf. Bernal Casasola 1999). En cuanto a la cronología de la serie, se imponía la idea de que las ánforas Dressel 1C y Dressel 21-22 eran más antiguas fechándose en el tercer cuarto del siglo I a.C., como había supuesto Domergue, mientras que las series de Dressel 7-11 y 12 correspondían ya a época imperial.

En 1970, Miguel Beltrán Lloris (1970) cambiaba los términos cronológicos de la cuestión al señalar una producción contemporánea entre Dressel 1C y Dressel 7-11 de El Rinconcillo, proponiendo una datación tardía (época augustea) para el inicio de su manufactura, y un límite superior reconocido en época de Claudio que era la fecha propuesta por M. Sotomayor para la actividad de los hornos excavados por él en Algeciras. Esta datación tardía de las Dressel 1C de El Rinconcillo no ha podido mantenerse tras la excavación en 1991 de otro sector de la alfarería por S. Fernández Cacho (1994; 1995), al que siguió una nueva intervención en el yacimiento con escasos resultados cronológicos en 2000 y una final en 2002 que ha permitido intervenir de nuevo en el área de los hornos excavados por Sotomayor y definir con algo más de claridad los límites del yacimiento (Bernal Casasola y otros 2004).

La estratigrafía obtenida en El Rinconcillo en 1991 por S. Fernández Cacho, consta de cinco fases sucesivas, de las que sólo las cuatro últimas corresponden a la actividad del alfar, para el que se propone el siguiente esquema funcional y cronológico (Fernández Cacho 1994: 88-90):

- Fase II: Corresponde a la instalación y funcionamiento de un pequeño horno cerámico dedicado tal vez a la fabricación de los opérculos de cierre de las ánforas. Segundo tercio del siglo I a.C. 
- Fase III: Nivel de abandono de la actividad alfarera en este sector de la alfarería y de amortización de las estructuras. Sin propuesta cronológica explícita, aunque los materiales parecen residuales y ofrecen una composición idéntica a la de las unidades estratigráficas de la fase anterior.

- Fase IV: Vertidos cerámicos procedentes de otras áreas del taller que se superponen a los niveles de amortización del mismo. Fines del siglo I a.C. y primer cuarto del I d.C.

- Fase V: Segundo vertido de material cerámicos sobre el anterior: segundo cuarto del siglo I d.C.

Según esta propuesta, la actividad del alfar se iniciaría (fases II y III) con la producción de ánforas de las formas Dressel 1A y C, ¿Haltern 70? y LC 67, a las que se unirían hacia fines del siglo I a.C. (fases IV y V) las Dressel 7-11 y las ánforas Clase 24.

Sobre este esquema cronológico inicial D. Bernal Casasola y R. Jiménez-Camino Álvarez (2004: 600) proponen las siguientes modificaciones que afectan a la datación de las fases establecidas por Fernández Cacho:

- Retrasar los inicios de la producción en el taller (fase II) hasta 100-75 a.C.;

- Establecer como límite cronológico superior (más reciente) de actividad de las fases IV y V la época de Augusto.

Esto supondría admitir unos inicios para la producción de las variantes locales de Dressel 1 en el primer cuarto del siglo I a.C., momento en el que estarían acompañadas por ánforas de la forma LC 67 . Hacia el tercio central del siglo I a.C. harían su aparición las Dressel 7-11 junto a las ánforas de la Clase 24. No se ofrecen datos suficientes acerca del aspecto macroscópico de las ánforas de los tipos Haltern 70 y Clase 24 que permitan asegurar su manufactura en el taller, por lo que su adscripción a estas series locales de El Rinconcillo es hipotética en el estado actual de la investigación.

Un examen detenido del repertorio cerámico documentado en las excavaciones de 1991 en El Rinconcillo que incluya, además de las ánforas, el resto del material cerámico, nos parece hace inclinarnos por la propuesta de datación inicial, la de Fernández Cacho, para los inicios de la producción en el sector por ella excavado (sector 3, fases II y III), en función de:

- La presencia de lucernas del tipo 2 de Dressel, más frecuentes en los contextos hispanos del tercio central del s. I a.C., que en los del primer tercio de la centuria, donde son más frecuentes las lucernas
Ricci E y Dressel 1. El facetado del disco de la lucerna de la UE 18 (fase II) ilustrado por Fernández Cacho (1995: fig. 14) nos parece que la encuadra en las lucernas Dressel 2A, con canal en el pico y propias de mediados del siglo I a.C;

- La presencia de las formas de paredes finas Mayet 3 y 3 A (UE 18, fig. 2), y ausencia de las formas I y II, propias de los decenios finales del siglo II y los iniciales del I a.C.:

- La presencia de las cazuelas de cocina itálicas Celsa 89.27 que se generaliza en estas fechas, aunque se trata de un tipo anterior en el tiempo.

Las fases IV y $\mathrm{V}$ deben ser fechadas en torno a la década de los 30 en función de:

- Las Haltern 70 de la UE 14 (Fernández Cacho 1994: fig. 7.8-11) cuyos bordes, grosor del cuello y perfil de las asas las asimilan a las Haltern 70 "iniciales" (del tipo Bolonia-Flota de Agripa, supra) fechado en la década de los 30 del siglo I a.C.;

- Las Dressel 7, en todo similares a las producciones iniciales de los alfares gaditanos de Gallineras-Cerro de los Mártires (García Vargas 1998).

- Las Clase 24 similares a las de Montée de Loyasse (Lyon) para estas fechas 40-20 a.C. (Desbat y Lemaître 2001: 805)

Finalmente, la fase V, con profusión de Dressel 7 iniciales, Haltern 70 y perduración de ¿LC 67? y Dressel $1 \mathrm{C}$ ? y con ollitas de borde vertical similares a las del repertorio itálico contemporáneo, si no ellas misma itálicas, se sitúa sin grandes problemas en torno a los decenios finales del siglo I a.C. (Desbat y Lemaître 2001: 806, La Muette y Rue des Farges, Lyon).

Los niveles de los sondeos 29 (Va), 26 (VI) y 40 (V) de Baelo Claudia que Cl. Domergue (1973: cuadro de síntesis en p. 105) propone fechar en el tercer cuarto del siglo I d.C. presentan un material anfórico y no anfórico coherente con esta cronología y sustancialmente coincidente en tipología y características técnicas con los de la fase II de El Rinconcillo, incluyendo entre las formas anfóricas Dressel 1C, LC 67 y también ánforas atribuidas a la forma $21 / 22$ de Dressel que, en virtud de sus elementos epigráficos, debieron ser fabricadas en los mismos talleres que los otros dos tipos. Este horizonte de Dressel 1C, LC 67 y "Dressel 21/22" es, pues, el característico de los decenios centrales del siglo I a.C. ${ }^{36}$ en el Estrecho y puede considerarse como

36. La producción y uso de las Dressel 21/22 aún sigue siendo objeto de controversia, al igual que el origen exacto de su 
una fase morfológica de clara influencia itálica previa a la formalización, a partir de 30 a.C., del repertorio "clásico" antoimperial, centrado ya en las Dressel 7-11 y Dressel 12 a las que desde fines de época augustea se unirán las ánforas del tipo Beltrán IIA (Beltrán Lloris 1977).

Que las facies mejor caracterizadas de las producciones anfóricas del Estrecho sean las que se fechan a partir de los años centrales del siglo I a.C. no significa que la producción comience necesariamente en estos momentos. Recientemente (Bernal y otros 2011) se ha propuesto la existencia de una producción anfórica en el entorno de Carteia entre fines del siglo II y comienzos del I a.C. sobre la base de fragmentos de desechos de alfar en distintos contextos de los sectores "púnico" y "romano" de este yacimiento de la bahía de Algeciras. Las piezas defectuosas corresponderían a ánforas de la forma 7.4.3.3. y, tentativamente, 9.1.1.1., lo que añadiría al panorama descrito con anterioridad una fase primera con ánforas de tipología tardopúnica a las que habría que añadir las Dressel 1A de fabricación local documentadas tal vez como material residual en la fase II del sector 3 de El Rinconcillo. El panorama completo de las producciones anfóricas republicanas del área del Estrecho en la orilla peninsular quedaría tras lo expuesto del siguiente modo:

- Horizonte tardopúnico y romanización inicial: fines del siglo 120-70 a.C. Formas producidas: Dressel 1A, 7.4.3.3. y i7.9.91?;

- Horizonte de romanización: 70/60-30 a.C. Formas producidas: Primeras Dressel 7-11, Dressel 1C, LC67, ¿Clase 24?, Dr. 21-22, ¿Haltern 70?

- Primer horizonte imperial: 20 a.C. -10 d. C.: Dressel 7-11, Dressel 12, ¿Haltern 70?,¿LC 67?, ¿Dressel 1?

\subsubsection{Costa mediterránea de la Ulterior}

Otra de las areas costeras sudhispanas en las que se documenta la producción de ánforas de tipología

\footnotetext{
producción, que parece estar en Italia meridional o tal vez en Sicilia. Ante la falta de ejemplares completos de fabricación hispánica, no puede asegurarse plenamente que los ejemplares de El Rinconcillo y Baelo Claudia sean versiones sudhispanas de estos envases. Sin embargo, el marco cronológico del tercer cuarto del siglo I a.C., coincide perfectamente con un momento en el que ya se observa la presencia de ejemplares itálicos en Ostia (Van den Werff 1986: 114, 117; en contra Botte 2009: 145). Si bien creemos que este último hace una mala lectura del texto de Van den Werff y de Bonifay 2004: 105)
}

romana en época republicana es la costa mediterránea de la Ulterior, integrada desde inicios de época imperial en el conuentus Gaditanus. A pesar de que aparecieron publicadas hace ya bastantes años (Arteaga Matute 1985), evidencias de una "industria" alfarera relativamente desarrollada en la Costa del Sol durante los siglos II y I a.C., lo cierto es que no se han experimentado avances sustanciales en su conocimiento arqueológico. El fenómeno del "boom" inmobiliario que ha permitido el reconocimiento y excavación de alfares púnicos y tardopúnicos en la bahía de Cádiz, no ha tenido el mismo impacto en las costas malagueñas y granadinas donde todos los talleres excavados en estos años arrancan de época alto o medioimperial (Figlinae Malacitanae 1997; Bernal Casasola, ed, 1998; García Vargas 2001).

Los trabajos en el Cerro del Mar (Torre del Mar, Vélez-Málaga) permiten documentar la presencia de bordes de ánforas de la forma 7.4.3.3. junto a otros de las series tardías del grupo de las 12.1.1.0. ya a fines del siglo II a.C. Si hemos de juzgar por la morfología del borde de las 7.4.3.3. del Cerro del Mar, y suponiendo que éstas sigan el modelo evolutivo de las gaditanas tal como ha quedado establecido por A. Sáez Romero (2008: 567), las ánforas de este tipo de los complejos 14 al 10 (Arteaga Matute 1985) deben fecharse entre 80/70 y 40/30 a.C., estando acompañadas en estos niveles por ánforas de la forma Ovoide 5 (complejos 13 al 11) y por bordes de LC $67^{37}$ desde el complejo 11 al 9 y Dressel $1 \mathrm{C}$ con bordes muy moldurados en los ejemplares más antiguos (complejos 14 al 11) y más rectos en los recientes (10 y 9). Sólo en los contextos del último tercio del siglo I a.C. (9 y 8), con presencia ya de TSI, las ánforas Dressel 1C, 7.4.3.3. y LC 67 (¿cuántos de los últimos tipos son residuales?) aparecen acompañadas de Dressel 7-11, lo que situaría la aparición de la forma en la costa malagueña hacia 4030 a.C. Excavaciones inéditas en el Cerro del Mar en 1998 documentan una evolución muy similar, siendo las pastas cerámicas de las Dressel 1, las 7.4.3.3. y las ánforas ovoides similares entre sí y de origen muy probablemente local.

37. Según informaciones orales del Prof. Oswaldo Arteaga, en las excavaciones dirigidas por el Dr. Niemayer en el emplazamiento de Toscanos, en la orilla opuesta a la que ocupa el Cerro del Mar en la desembocadura del río Vélez, el prof. Niemayer detectó un horno productor de estas ánforas LC 67 . Otra posible alfarería con producción de esta forma estaría ubicada en la antigua Barbesula, actual yacimiento de Guadiaro (San Roque, Cádiz), en el límite entre las provincias de Cádiz y Málaga (Cf. García Vargas 2001: 71). 
Algunos fragmentos descontextualizados de bordes en apariencia similares a los de las ánforas 7.4.3.3. en el alfar de la Calle Carretería, Málaga (Rambla y Mayorga 1997: fig. 5, $\mathrm{n}^{\circ}$ 17), han servido para proponer unos inicios de la producción cerámica en el mismo siglo I a.C. Pero lo cierto, es que, si se observa con detenimiento, el borde de este ejemplar corresponde a una Beltrán IIB un tanto peculiar, pero reconocible, lo que, en principio, nos deja sin testimonio alguno publicado para una producción cerámica republicana en la capital malagueña, a no ser que el borde de, esta vez sí, 7.4.3.3. publicado por A. López Málax-Echeverría ( 1971-1973) como procedente del alfar altoimperial de Puente de Carranque (1971-1973, fig. 11.8) corresponda a una producción del alfar. Del mismo lugar, se ilustra otro fragmento que puede corresponder a LC 67 (muy sumariamente dibujada: fig. 11.2) lo que permite suponer, si las piezas aducidas corresponden a las producciones iniciales del taller, unos inicios para la actividad del mismo en el siglo I a.C. sin más especificaciones.

En conclusión, la evolución de la costa mediterránea de la Ulterior parece similar a la de las costas atlánticas de la provincia, con producción de ánforas de tipología púnica (12.1.1.0 y 7.4.3.3.) y primeras ánforas itálicas del tipo Dressel 1 entre 120 y 80/70 a.C., una producción que incluye 7.4.3.3., Dressel 1C, LC67 y Ovoide 5 local, en las décadas centrales del siglo I a.C. y la aparición de la serie de las Dressel 7-11 hacia 40/30 a.C.

\subsection{La Tarraconense Oriental}

Es evidente que en el área catalana se asiste a la expansión del cultivo de la vid durante el siglo I a.C., que va acompañada de cambios en el sistema productivo que han podido ser bien identificados y que se manifiestan en varios niveles (Revilla Calvo 1995). Así, junto con la creación de nuevos núcleos urbanos plenamente romanos y a la puesta en marcha de una nueva organización del territorio fundamentado en los esquemas lógicos de centuriación territorial, se observa la aparición y expansión del sistema de explotación del territorio basado en villae, en el que es innegable el papel relevante que juega el cultivo de la vid con vistas a su exportación excedentaria. Este fenómeno de expansión del cultivo de la vid es un tema ampliamente conocido, que conlleva la aparición de tipologías anfóricas basadas en los prototipos romanos más comunes del momento y que podría dividirse en las siguientes etapas temporales:

\subsubsection{Imitaciones de las producciones itálicas} (desde las décadas finales del siglo II a.C., hasta el tercer cuarto del I a.C) $)^{38}$

En este proceso, al igual que en la Ulterior, se ha de señalar una mínima producción de imitaciones de los tipos finales de ánforas grecoitálicas (tipos D y E de Will), así como la constatación en Mataró de un lote de Lamboglia 2 con pastas típicas de la zona del Maresme (López Mullor y Martín Menéndez 2008: 43-44, fig. 3. 4-6). Sin embargo, fundamentalmente se han de resaltar las imitaciones de las variantes A, C y sobre todo B, de las Dressel 1, que en algunos casos parece que fueron exportadas allende la región catalana.

\subsubsection{Inicio de producciones propias, ánforas con rasgos "ovoides" (segunda mitad del siglo I a.C.).}

El siguiente paso tras el periodo dominado por las imitaciones itálicas, vendría dado, al igual que en el caso del sur de Hispania, por la creación de un universo formal propio, que se concretaría en las denominadas Tarraconenses 1, 2 y 3 (López Mullor y Martín Menéndez 2008: 44-55). Esta serie de formas, con gran variación formal entre unas y otras pero con rasgos comunes, empiezan a ser producidas en los años centrales del siglo I a.C., probablemente algo después del inicio de las producciones ovoides béticas.

La división efectuada por A. López Mullor y A. Martín Menéndez entre los tipos Tarraconense 1A hasta E, 2 y 3, si bien es cierto que no está exenta de problemas, no es sino un valiente intento por poner orden a un universo formal que, al igual que en el valle del Guadalquivir, se encuentra en plena evolución, conviviendo un buen número de morfologías tas. Más allá de las similitudes del proceso en sí, resulta evidente que ciertos tipos tarraconenses tienen una gran similitud con algunas de nuestras tipologías ovoides. De este modo, las tarraconenses $1 \mathrm{C}$ y sobre todo las $1 \mathrm{D}$, guardan gran parecido con las Ovoide 4 del Guadalquivir e incluso primeras formas de Haltern 70, mientras que el tipo Tarraconense 3, cuya producción únicamente ha

38. López Mullor y Martín Menéndez (2007: 41-42) llevan la producción de Dressel 1 en la Tarraconense hasta la primera década de la segunda mitad del siglo I a.C., y si bien es cierto que remarcan que puede que perduren hasta el final del segundo cuarto a.C., creemos dudosa la presencia de Dressel 1 tarraconenses en yacimientos con cronologías posteriores como Dangstetten (Ehmig 2010), ya que a día de hoy no tenemos su presencia constatada en contextos de la propia provincia, su principal área de expansión. 
sido documentada en los vertederos asociados a la villa de El Vilarenc (Calafell), es posible que pueda tratarse de una especie de "imitación" local de las Ovoide 1 (Clase 67/LC67) del Guadalquivir.

Las ánforas adscribibles al tipo Tarraconense 1A, mayoritariamente producidas en la costa de la Laietania central y septentrional, son también más frecuentes de lo que hace bien pocos años se podría pensar, particularmente en contextos de la actual Cataluña y área francesa cercana. A lo largo de las últimas tres décadas generaron frecuentes problemas y dificultades en su clasificación, definición y caracterización al ser confundidas con las formas ovoides del Guadalquivir, principalmente el tipo Ovoide 1 (Clase 67/LC67). Afortunadamente, este panorama se encuentra hoy en gran medida superado, existiendo un buen cuadro de definición formal basado no solo en los atributos formales si no también en la petrografía de las producciones layetanas (Martín Menéndez 2008; López Mullor y Martín Menéndez 2008).

Así mismo, para los casos actualmente conocidos en que se posee una caracterización/ descripción petrográfica, o representación gráfica de calidad, y puede llegar a determinarse la procedencia de la pieza, es posible verificar la presencia conjunta de los tipos Tarraconenses y de ánforas ovoides sudhispanas (principalmente del Valle del Guadalquivir), en yacimientos terrestres del sector oriental peninsular fechados groso modo en mediados del siglo I a.C. Aún más reveladores que los contextos terrestres -en los cuales pueden esperarse dichas asociaciones, siendo más difícil determinar la naturaleza o el grado de fiabilidad de las mismas- son los hallazgos subacuáticos, que ilustran de forma inequívoca la circulación de productos béticos y tarraconenses en contenedores con morfologías similares.

Buen ejemplo de ello son los naufragios Illes Formigues $\mathrm{I}^{39}$ y Cala Bona I, que nos aportan no solo una prueba segura de la contemporaneidad existente por lo menos desde mediados del siglo I a.C., entre los tipos Ovoide 3, 4 y 5 del Guadalquivir y los tarraconenses, concretamente varias variantes de Tarraconense 1 , sino también una buena muestra de la comercialización conjunta de estos contenedores con procedencias distintas, dentro de un comercio que sobrepasaba el ámbito peninsular inmediato, alcanzando otras provincias, que en el caso particular de los pecios mencionados parecen

39. Este naufragio es habitualmente conocido en la bibliografía de referencia como Palamós, cuyo conjunto anfórico fue revisado y oportuna estudiado por A. Martín Menéndez (2008). ser los mercados de la narbonense (Martín Menéndez 2008: 103).

A modo de conclusión de este punto, tenemos que añadir que, en nuestra opinión, la aparición de las tipologías con rasgos ovoides en el Noreste peninsular, se enmarca dentro de un proceso complejo que la falta de datos arqueológicos concluyentes impide precisar, pero en el que creemos que hay varios factores que juegan un papel importante, destacando dos de ellos. El primero sería que la exportación vinícola del Noreste hispano, y junto a ella evidentemente la producción anfórica, ha alcanzado ya un punto cuantitativo que hace posible su reconocimiento en los mercados de importación, sin que sea necesario recurrir al "préstamo" de otros tipos anfóricos. Por el contrario, se hace más bien necesario el poder encontrar un envase de características propias que pueda asimilarse con un contenido plenamente individualizado, en este caso los vinos de la región. El segundo factor a tener en cuenta sería el recurrir para los prototipos anfóricos a una corriente generalizada, que en este caso se materializa con las ánforas de tipología ovoide de la zona de Bríndisi, los tipos antiguos de ánforas tripolitanas, y desde nuestro punto de vista con las tipologías ovoides del sur de Hispania, entre las que habría que destacar a las Ovoide 1 (Clase 67/LC67) y las Ovoide 4 y 5, que aparecen ya en algunos contextos tarraconenses de inicios de la segunda mitad del I a.C. (para el área de Tarraco: Gebellí y Díaz, 2001; Díaz y Otiña, 2003; Díaz, 2000, 2009;), y que son los tipos con los que mayor semejanza tipológica parecen guardar.

\subsubsection{Consolidación de mercados más cercanos y exportaciones masivas hacia Gallia (último cuarto del I a.C., primero del I d.C.).}

Desde el último tercio del I a.C. o quizás un poco antes, se produce en la mayor parte de los alfares del territorio del posterior conventus Tarraconensis, la forma Pascual 1, que es una de las ánforas de época augustea que mayor difusión encontró, orientándose su exportación principalmente hacia las regiones del sur de Galia, pero llegando en buen número al área atlántica francesa, a los campamentos germanos del Rin y sus afluentes, y a los mercados itálicos tirrénicos. La consolidación del mercado galo como el principal receptor de ánforas tarraconenses, llevó a que la mayor parte de los envases fuesen transportados por vía fluvial aprovechando la magnífica red de ríos con la que se cuenta al norte de los Pirineos. Ello se adaptaba 
perfectamente a las características de las ánforas de fondo plano, entre las que destaca la Oberaden 74, producida en época de Augusto y Tiberio en varios alfares del noreste peninsular y que curiosamente parecen tener un destino destacado en los campamentos militares del área renana (Carreras y González Cesteros e. p. b), si bien hay que tener en cuenta siempre que se trata de un tipo minoritario tanto en los alfares en los que fue producida, como en los centros de importación localizados.

La producción de estos dos envases amplía el número de alfares conocidos en el noroeste de la tarraconense con respecto al periodo anterior, aunque muchos de los que estaban activos anteriormente parecen seguir haciéndolo en estos momentos, entre otras razones debido a que en muchos de ellos se produjeron de manera contemporánea los tipos Tarraconenses y las Pascual 1 y Oberaden 74. Centrándonos en las características de los nuevos tipos que asoman en este periodo, si bien la creación de los envases de fondo plano parece ser algo totalmente nuevo que estaría en relación con la "conquista" del interior por medio de los ríos en el norte de Hispana y área galo-germana, resulta evidente que las Pascual 1 son unas ánforas que guardan una gran similitud con algunos de los tipos señalados de Tarraconense 1 y que han de derivar directamente de ellas. Sin embargo, en este caso, al contrario que en el valle del Guadalquivir para la Haltern 70, no puede decirse que estemos ante un ánfora con "reminiscencias" ovoides, ya que es plenamente cilíndrica, estando su cuerpo más cercano de tipos tirrénicos como las Dressel 1 o las Dressel 2-4.

\subsubsection{Cambio de mercados unido a cambios tipológicos. La fabricación de Dressel 2-4 tarraconenses (fines del siglo I a.C./siglo I d.C.).}

A mediados del principado de Augusto se da un proceso curioso de vuelta a la imitación de tipos dominantes en las producciones tirrénicas. La causa de este proceso viene motivada por un cambio de mercado, ya que progresivamente el mercado de las Galias comienza a cerrarse para los vinos tarraconenses y pasa a ser Roma el lugar de importación más relevante. No obstante, es cierto que las Dressel 2-4 tarraconenses tienen unas características formales propias, y estamos de acuerdo con A. López Mullor y A. Mártínez que tal vez sería más correcto denominarlas simplemente Dressel 2-3, ya que la forma 4 de la tabla de Dressel no se produjo en los alfares del noreste peninsular.
Este cuarto periodo ha de ser considerado como un paso peculiar dentro de la producción anfórica de época romana, y nos atrevemos a asegurar que las regiones vinícolas del conventus Tarraconensis, son las únicas zonas productoras en las que, durante el periodo tardorrepublicano y altoimperial, tras haberse activado la fabricación de ánforas con unas tipologías propias, optan por abandonarlas en pro de la imitación de prototipos ajenos. No vamos a seguir por esta línea, ya que adentrarnos en profundidad en los motivos de esta peculiar evolución formal, sobrepasa con creces el ámbito temporal de nuestro trabajo.

Como es evidente, a excepción del vuelco tipológico de la última fase, podemos afirmar a grandes rasgos que estamos ante un esquema similar al que se desarrolla en el sur hispano, en el que partiendo de la imitación de las ánforas itálicas más difundidas, se llega a la aparición de un repertorio tipológico propio que tiene una primera fase "ovoidal", en este caso materializada por algunas de las distintas variantes de las formas Tarraconense 1 y 2 (López Mullor y Martín Menéndez 2008), al que le sigue un nuevo envase que partiendo de los tipos ovoides más estilizados, se consolida al abrirse hueco de manera definitiva en los mercados exteriores. Pensamos que es bastante lógico que el proceso evolutivo en el sur y noreste hispano sean similares, ya que puede asegurarse que en los dos casos se persigue el mismo fin, que no es otro que exportar los excedentes de la producción local agropecuaria en una cantidad cada vez mayor y a mercados más amplios.

\subsection{La Lusitania costera occidental}

El arranque de la producción anfórica en época romana en la costa occidental lusitana, y las lagunas que se hacen sentir actualmente en su estudio, recuerdan enormemente lo ocurrido en la investigación para la misma etapa en el valle del Guadalquivir. De hecho, parece que asistimos a un dejá vu que radica en: ausencia de datos relativa a centros productores versus abundantes datos en centros de consumo. Así mismo, el panorama de la evidencia material referente al origen de la producción de contenedores de transporte cambió radicalmente en la última década, habiéndose pasado de consolidadas síntesis en que se subrayaba su carácter claramente romano y de época imperial (Fabião 2004b: 401) a la existencia de producciones con origen incierto, pero seguramente atribuibles a la segunda mitad del siglo I a.C. (Morais 2004b; Morais y Fabião 2007). 
Las evidencias más antiguas de la producción romana remontan únicamente al período julio-claudio, concretamente a época tiberiana, y proceden de los alfares del Largo da Misericórdia (en el área urbana/ periurbana de la ciudad de Cetobriga, Setúbal: Silva 1996), Pinheiro y Abul (Mayet y Silva 1998 e Mayet e Silva 2002), todos en el bajo Sado, y aparentemente también en Morraçal da Ajuda, en Peniche (Cardoso y Rodrigues 2005; Cardoso otros 2006), en la costa central atlántica. Las formas producidas en esta esta etapa inicial, y que carecen aún hoy de sistematización, revelan notorias afinidades con las existentes en la Hispania meridional, particularmente con las Haltern 70 del Guadalquivir y la familia de las Dressel 7-11 de los talleres gaditanos, con las cuales a menudo se establecen conexiones formales (cf. Fabião 2004a y 2008, para detallada problemática).

Este panorama, que actualmente ya sorprende como tardío, contrasta sobre manera con una serie de yacimientos y conjuntos anfóricos, con contextos y cronologías no siempre muy claros o precisos, pero seguramente atribuibles a la segunda mitad del siglo I a.C., mayoritariamente al último cuarto de la centuria, donde se hace evidente la expresión y presencia significativa de fragmentos con características petrográficas atribuibles al complejo bajo Tajo/Sado y con morfologías que se pueden relacionar con las formas romanizadas de las ánforas béticas (Fabião 2008: 725-726).

Los tipos que cobran más relevancia son justamente los que se pueden atribuir a la familia de ánforas ovoides, que, tal como se encuentra definida actualmente (Morais y Fabião 2007), presenta una gran variedad formal. No obstante, el estado muy fragmentario de gran parte de los ejemplares conocidos tampoco permite lecturas tipológicas conclusivas (de hecho para la mayor parte de los mismos no se puede ni siquiera asegurar su "condición" de ánfora ovoide...). Esta premisa parte de la evidente similitud formal al nivel de las bocas entre muchos de estos fragmentos (cf. Morais 2004 y Morais y Fabião 2007 para un análisis detallado) y parte de los tipos béticos romanos que se presentan en este trabajo, concretamente las Ovoide 1 y 4, pero también con morfologías ovoides de origen gaditano, e inclusive morfologías atribuibles a las primeras formas de la serie de las 7-11. De un modo general, y dada la tendencia que se desarrollará posteriormente, se acepta que se trata de formas que se destinaban a contenidos piscícolas (Morais y Fabião 2007: 132).

El mapa de distribución no se encuentra circunscrito a un área particular, aunque se observa un mayor número de ocurrencias en la cuenca del Tajo y afluentes directos, presentando más bien una dispersión amplia en la fachada atlántica y en las áreas de penetración inmediata, sobre todo en los cursos de los grandes ríos, incluida la actual Galicia. Importa destacar la ausencia momentánea de estos tipos anfóricos en la costa meridional de la futura provincia Lusitania, aspecto que no se debe seguramente a la ausencia de investigación ${ }^{40}$, sino a otros factores para los cuales no existen respuestas por el momento. Los sitios cuyos hallazgos de ejemplares "lusitanos antiguos" los convierten en puntos de atención obligatoria son groso modo los mismos de referencia para los circuitos de distribución de los productos béticos del interior y de la costa a partir de mediados del siglo I a.C., mayormente coincidentes con contextos de conquista o de control y gestión de los recursos o del territorio, con carácter militar o militarizado -destacando Lisboa (Bugalhão 2001; Filipe 2008a; Filipe 2008b), Santarém (Arruda, y otros 2006), Castelo da Lousa (Morais 2010a), sitios del Alentejo central (Mataloto 2008)- y yacimientos urbanos y rurales integrantes del proceso de "romanización" y articulación de los territorios interiores de las principales cuencas fluviales -Alcácer do Sal (Pimenta y otros 2006), Coruche (Quaresma y Calais, 2005), Aljube/Oporto (Morais y Fabião 2007) y gran número de yacimientos en el bajo Duero y Miño (Morais 2004b).

A pesar del gran número de sitios y conjuntos materiales hoy por hoy conocidos, nos parece - sin que poseamos una base empírica consistente, debido a la referida carencia de contextos y cronologías finas que permitan datar también el "arranque" de su recepción - que el inicio de producción/circulación no deberá retroceder hasta mediados del siglo I a.C., tal como últimamente se viene planteando (Morais 2004: 40; Morais y Fabião 2007). El hecho de que sea justo en estas fechas cuando se asiste al despegue de las importaciones del Guadalquivir en territorio de la futura Lusitania, coincidente con el proceso de conquista tardío de parte de ese territorio; su ausencia, por ejemplo, en los contextos tardorrepublicanos de Santarém (Almeida 2008: Capítulo 7; Arruda y otros 2006), o de Lisboa (Filipe 2008; Filipe 2008b), y su presencia significativa en Castelo da Lousa (Morais 2010a) o en otros castella y fortines del Alentejo central, del entorno de la ciudad de Ebora (Évora) a la cuenca del Guadiana, estos últimos de cronología aparentemente algo posterior, del

40. El reciente estudio de C. Viegas (2011), para los núcleos urbanos del Algarve central y oriental con certificada ocupación del siglo I a.C. y d.C. no reveló la presencia de alguno de los tipos ovoides lusitanos. 
inicio del último cuarto del siglo I a.C. (Mataloto 2008: 139ss), nos lleva a considerar que es en un momento algo más avanzado, probablemente coincidente con el inicio del principado, cuando debe de arrancar la producción de esas ánforas lusitanas de clara inspiración bética. La estrecha afinidad entre los repertorios iniciales de ambas provincias, con las debidas reservas impuestas por el lapsus de tiempo existente entre el inicio de la producción en cada una, parece sugerir, tal como otros autores han tenido la sagacidad de plantear, una relación que se puede deber al desplazamiento de alfareros béticos hacia las alfarerías del extremo occidente peninsular (Morais y Fabião 2007: 132).

\section{A MODO DE CONCLUSIÓN}

Dada la extensión que ha tomado ya este trabajo dedicado a la reordenación y actualización tipológica de la evidencia material sobre las ánforas republicanas del valle del Guadalquivir, quisiéramos desarrollar en este apartado unas conclusiones no demasiado extensas, en las que quedaran enmarcadas las líneas de trabajo que creemos han de seguirse en el futuro, pero sin meternos de lleno en las conexiones conceptuales entre la tipología y la investigación histórica y económica, sino tan sólo retocar algunos apuntes de carácter tipológico, cronológico, funcional y económico que se desprenden de lo señalado hasta ahora, es decir, casi como si se tratara de realizar una apretada síntesis de lo dicho en la que enfaticemos sobre todo determinados aspectos de especial interés.

El primero de ellos es el esfuerzo por presentar una tipología analítica que reúna en un mismo trabajo la sorprendente cantidad de tipos regionales producidos entre fines del siglo II a.C. y fines del I a.C. A pesar de la aparente falta de unidad y de la caótica proliferación de formas cerámicas para un mismo cometido o para cometidos muy similares, hemos propuesto algunas líneas de sistematización tipológica que nos parecen al menos útiles en el estado actual de la investigación.

La primera es la posibilidad de incluir los distintos tipos en varios grupos en función de la procedencia de su morfología y de su "éxito" en los "mercados". Estos grupos son:

- Los tipos regionales que imitan contenedores de otra procedencia geográfica que alcanzaron cierta distribución en las áreas interiores del valle del Guadalquivir. En el grupo se incluyen las formas "heredadas" de la tradición artesanal prerromana, muy influenciada desde siempre por los desarrollos de los establecimientos semitas de la costa andaluza;

- Aquellos tipos que no imitan fielmente morfologías extrañas, sino que se inspiran en ellas (especialmente en la suditálica) para dar lugar a un conjunto de contenedores característicos del Guadalquivir que sin embargo pueden ser considerados como formas de vida breve con escaso éxito en los mercados (supra);

- Un grupo conceptual y formalmente similar al anterior, pero que está integrado por morfologías regionales con éxito significativo en los mercados. La mayoría de las bien conocidas ánforas imperiales del valle del Betis derivan de uno u otro de estos tipos iniciales, también con un reconocible "aire" suditálico, especialmente adriático;

- Un grupo que es el que enlaza ya con las producciones imperiales y que corresponden a los primeros contenedores que sufren un proceso de "estandarización" incipiente, y que será objeto de exportaciones masivas desde época augustea. Hay que señalar que en este grupo hemos incluído contenedores que si bien no fueron producidos de forma masiva, si que llegaron a los mismos mercados que el resto.

La segunda es la posibilidad de "entroncar" las producciones regionales con formas "de referencia" que parecen haber servido como punto de apoyo o como "inspiración" para el surgimiento de las morfologías de la Baja Andalucía. El elenco de formas únicamente sigue fielmente las características tipológicas de uno o varios "prototipos" de referencia durante la primera mitad del siglo I a.C., en que se imitan ánforas itálicas de las formas Dressel 1A-C y tardopúnicas gaditanas de la serie de las 7.4.3.3. Hacia el tercio central del siglo I a.C., se desarrollan, sin embargo, formas muy variadas de las que, como se ha dicho, al menos algunas (Ovoide 1, Ovoide 4, Ovoide 5 y Ovoide 6) tuvieron un cierto "éxito" interprovincial. De todas, tan sólo la Ovoide 6 se asocia claramente a un contenido concreto: el aceite, mientras que para la Ovoide 4

se deduce sobre la base de sus problemáticas relaciones con Haltern 70, y en los ejemplares con el interior resinado recuperados en Illes Formigues 1, un contenido vinario o de productos relacionados con la uva. En este segundo momento de producciones regionales "romanizadas", no se observan copias fieles, sino, todo lo más, influencias cruzadas entre tipos que generan un 


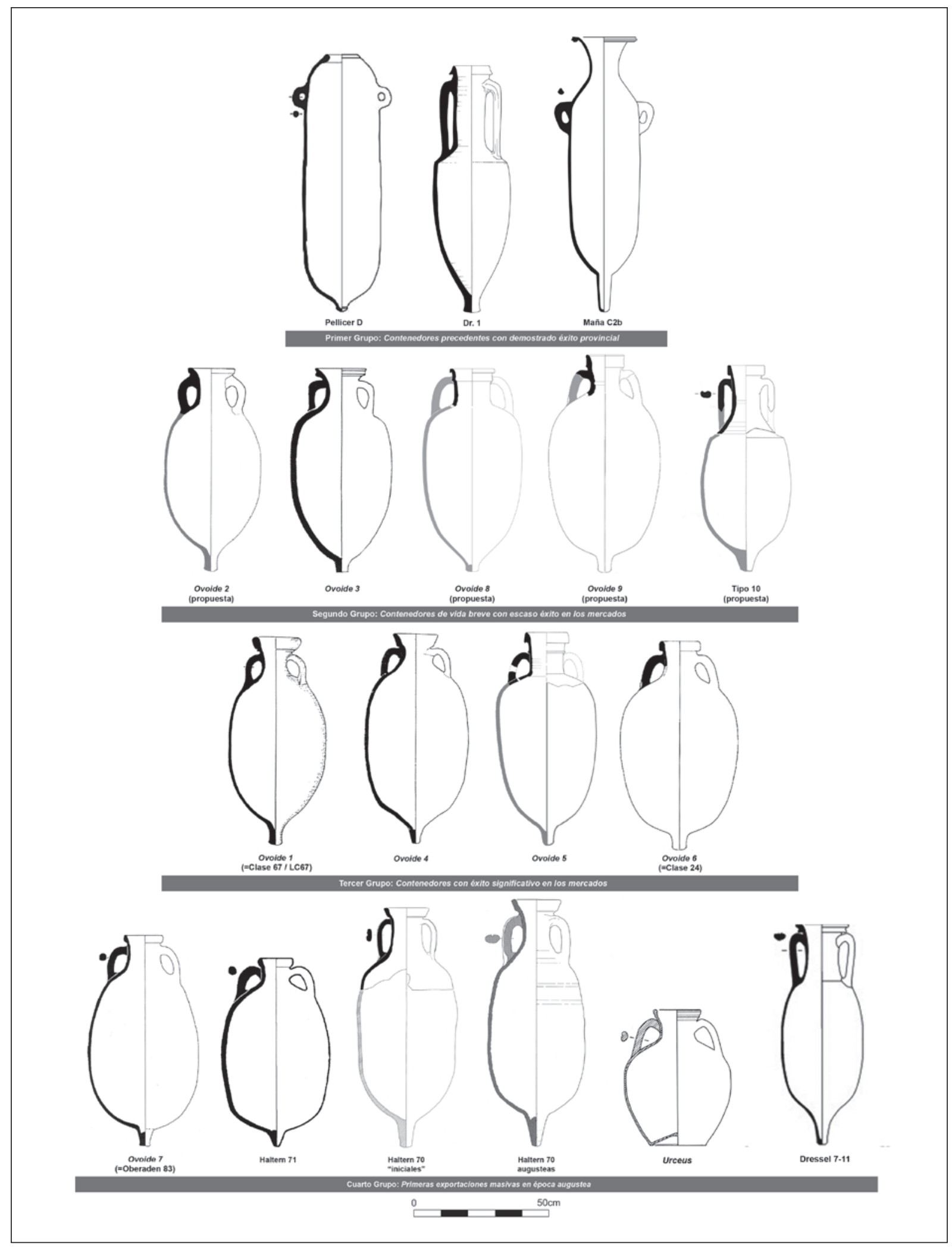

Figura 34. Repertorio anfórico del Guadalquivir durante el siglo I a.C. 
1. Caesarea Maritima

2. Éfeso

3. Brindisi

4. Apani / Giancola

5. Herdonia

6. Palombina

7. Cesano de Senigallia

8. Ostia

8. Ostia, Casa del Porche

8. Ostia, Termas del Nuotatore

9. Roma

10. Lavezzi 1

11. Sud-Lavezzi 2

12. Gianuttri

13. Sud-Perduto 2

14. Cap Gros "C"

15. Titán

16. Cap Sicié

17. Madrague des Giens

18. Planier 5

19. Grand-Conglué 3

20. Port-Vendres II

21. Albintimilium

22. Fréjus

22. Fréjus, Campo de la Flota de Agrippa

23. Castells

24. Vieille Toulouse

25. Malard

26. Sant-Romain-en-Gal

27. Lyon

27.1. Lyon, Loyasse

27.2. Lyon, santuario Cybèle

27.3. Lyon, rue de la Favorite

28. Augusta Raurica / Augst

29. Vindonissa

30. Dangstetten

31. Rödgen

32. Trier

33. Neuss

34. Nimega

35. Haltern

36. Oberaden

37. Anreppen

38. Cartago

39. Ceuta, pecio

40. Kouass, Arcila

41. Lixus

42. Thamusida

43. Sala

44. Rabat, pecio

45. Cabrera 5

46. Colonia San Jordi

47. Portopí

48. Culip VIII

49. Cala Bona I
50. Ampurias

50.1. Ampurias, Cardo D

51. Illes Formigues I

52. Iluro

53. Mataró

54. Badalona, Baetulo

55. Santa Perpétua de Mogoda, Vallès

56. El Villarenc

57. Tarragona, Tarraco

58. castellum de Puigpelat, Alt Camp

59. Celsa

60. Benicarló, pecio

61. Valencia, Valentia

61.1. Valencia, Plaza de la Reina

61.2. Valencia, Corts Valencianes

62. Valeria

63. Ercavica

64. Segobriga

64.1. Segobriga, Rasero de Luján

65. Pozo Sevilla

66. Denia

67. Punta del Arenal (Duanes)

68. Lucentum

69. El Monastil (Elda)

70. Portus Ilicitanus

71. Ilici

72. San Ferreol

73. Cartagena, Carthago Nova

74. El Molinete (Cartagena)

75. Loma de Herrerías (Mazarrón)

76. Cueva de las Peñas Blancas

77. Cerro del Mar

78. Málaga, C/ Carreteria

79. Guadiaro, Barbesula

80. El Rinconcillo

81. Baelo Claudia

82. Ensenada de Bolonia

83. Vejer de la Frontera, Convento de las Concepcionistas

84. San Fernando

84.1. San Fernando, Campo Soto

84.2. San Fernando, Cerro de Los Mártires

84.3. San Fernando, Gallineras

84.4. San Fernando, La Milagrosa

85. Cádiz

85.1. Cádiz, c/ Gregorio Marañón

85.2. Cádiz, Casa del Obispo

85.3. Cádiz, La Caleta

85.4. Cádiz, Plaza San Antonio

85.5. Cádiz, Avenida de Portugal

86. Puerto Real

86.1. Puerto Real, Cerro de Ceuta

87. Puerto de Santa Maria

87.1. Puerto de Santa Maria, Castillo de Doña Blanca
Figura 35. Mapa con los sitios referidos en el texto.

87.2. Puerto de Santa Maria, C/ Javier de Burgos

87.3. Puerto de Santa Maria, Jardin del Cano

88. Jerez de la Frontera

88.1. Jerez de la Frontera, C/ Troilo

88.2. Jerez de la Frontera, Rabatún

89. Rancho Centeno

90. Cerro Overo

91. Dos Hermanas, Orippo

92. Coria, Cauria

93. Osset, San Juan de Aznalfarache

94. Cerro de la Cabeza, Laelia

95. Sevilla, Hispalis

95.1. Sevilla, Calle Alemanes 25

95.2. Sevilla, Palacio Arzobispal

95.3. Sevilla, Patio de Banderas del

Alcázar

96. Santiponce, Italica

97. Alcalá del Rio, Ilipa Magna

97. Ilipa

98. Carmona, Carmo

98.1. Carmona, Albollón

98.2. Carmona, C/ Doctor Fleming

98.3. Carmona, C/ González Parejo

98.4. Carmona, C/ Montánchez

99. Munigua

100. Écija, Astigi

101. Posadas, Detumo

101.1. Posadas, Dehesa de Arriba

102. Córdoba, Corduba

103. La Loba

104. Tejada la Nueva, Ituci

105. Cerro del Moro

106. El Castillejo

107. Huelva, Onuba

108. Castro Marim

109. Cerro do Cavaco, Tavira

110. Faro

111. Monte Molião

112. Mesas do Castelinho

113. Mértola, Myrtilis

114. Castelo da Lousa

115. Quinta do Almaraz

116. Lisboa, Olisipo

117. Santarém, Scallabis

118. Alto dos Cacos

119. Chões de Alpompé, Moron?

120. Lomba do Canho

121. Porto, Aljube

122. Braga

123. Castro Santa Trega

124. Castro de Vigo

125. Castro de Montealegre 

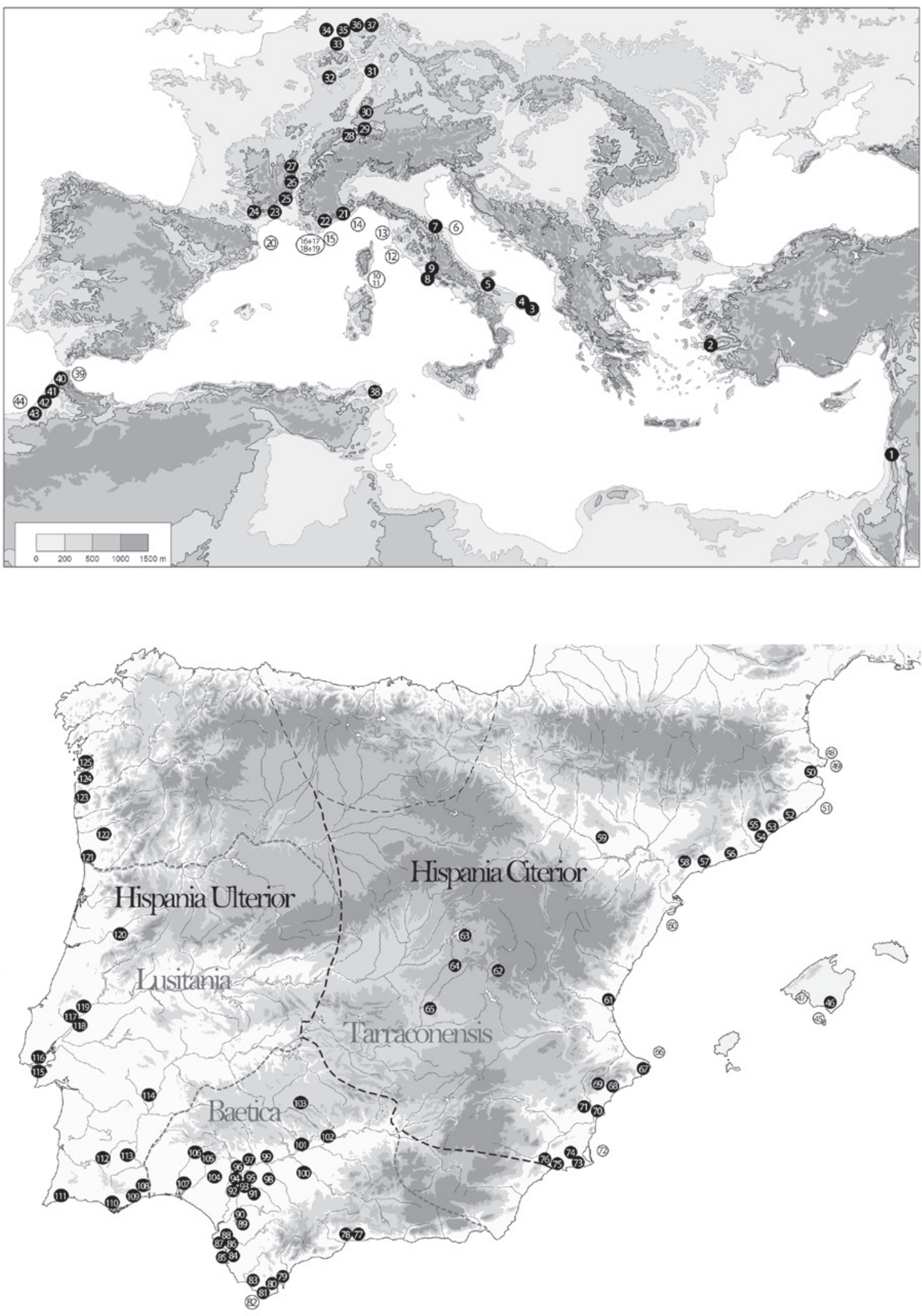

ISSN: $1133-4525$ ISSN-e: $2255-3924$ 
elenco anfórico amplísimo con un cierto "aire adriático", o más concretamente, brindisino. Así, un mismo tipo ovoide itálico, parece dar lugar o influir en la formación de varios tipos ovoides hispanos. Este es el caso, por citar sólo un ejemplo, de la forma VII de Apani cuyos rasgos son reconocibles tanto en la Ovoide 4 como en la Ovoide 9 o 6, de la Ulterior, mientras que ésta última recibe a la vez influjos "directos" de la forma IIIA de Apani. Sin embargo, la total ausencia de sellos en la Ulterior hasta después del cambio de Era, frente a su abundancia en Apulia, es un recuerdo oportuno de que, aunque pueda suponerse la existencia de artesanos emigrados de una zona a otra, no debieron ser similares las estructuras de la producción entre ambos mundos, y esto tal vez explique en parte las tempranas diferencias formales. La existencia de dos mundos artesanales muy diferentes es evidente, por ejemplo, en detalles técnicos como la morfología de los hornos cerámicos, que en Italia mayoritariamente son de forma cuadrada con sustentación de la parrilla medial mediante muros con arcos, mientras que en el Guadalquivir casi siempre suelen ser redondos con pilar central y parrilla sustentadas en un trasdós abovedado, lo que puede interpretarse como una perduración de las formas de hacer del artesanado local prerromano o turdetano ${ }^{41}$.

De hecho, el interior del valle del Guadalquivir parece diferenciarse también de la Apulia en que es una región que, si hemos de parafrasear la expresión de Estrabón (3.2.1-141-), referida a la colonia hispalense, estaba poblado de forma poco "brillante", es decir, adolecía de miembros de los ordines superiores de la sociedad con residencia fija en ella. Esta es una situación contraria a la que encontramos en la Apulia republicana (Manacorda 1988, 2001) donde los "medios de producción" relacionados con el cultivo y la exportación de las mecancías agrarias se encontraban claramente en manos de élites locales y también de familias senatoriales emigradas o absentistas una parte del año, al tener su residencia en Roma.

El repertorio anfórico del Guadalquivir no creemos que refleje entonces un mundo formal ligado a estas estructuras sociales suditálicas, sino que más bien se inspira en un "repositorio" formal surgido en otro lugar y que corresponde a otro universo de relaciones económicas y sociales. En cierta medida puede verse cierto paralelismo en los tipos monetales de las ciudades de la Ulterior republicana en este mismo siglo I a.C., los cuales representan (Chaves 2005) una imitatio formal, más o

41. Cf. la aportación a este mismo volumen de F. J, García Fernández y E. García Vargas. menos próxima, de referentes ideológicos metropolitanos, pero a cargo de elementos subalternos socialmente que, sin embargo, gracias a su ciudadanía romana o latina, comenzaron a destacar en medio provincial.

La emergencia social de las elites provinciales es un fenómenos posterior y se encuentra ligada a la intervención estatal en la producción y distribución del aceite bético $y$, por eso mismo, se relaciona con formas anfóricas ya fuertemente estandarizadas, normalizadas y selladas, cuyos primeros pasos se encuentran aún sepultados en las decenas de alfarerías rurales del Guadalquivir y del Genil que esperan aún ser excavadas y cuyo estudio se encuentra ya fuera del marco cronológico que aquí consideramos.

Con respecto a la distribución de las ánforas republicanas sudhispanas, si bien en principio muchas de ellas se constatan en contextos militares previos a la etapa augustea, o abandonados durante estos años, también las encontramos en núcleos civiles del interior peninsular en el tercer cuarto del siglo I a.C. Según nuestra opinión, puede decirse que las necesidades de abastecimiento que durante más de un siglo acuciaron a los ejércitos romanos en la Península Ibérica y las necesidades de abastecimiento de las áreas mineras, acabaron haciendo que se desarrollase una producción agropecuaria significativa en el sur de la Península. Ello llevó a que la región del Guadalquivir, perfectamente comunicada con la costa pero también relativamente bien con el interior, se constituyese como uno de los "epicentros" abastecedores de estos contingentes, principalmente con aceite, lo que no excluye que también fuesen exportados vinos y otros productos derivados de la vid, como bien parecen mostrar desde las imitaciones de Dressel 1 y algunos tipos ovoides, hasta la fabricación de envases de fondo plano, e incluso salazones como parece manifestar la producción de Dressel 7-11. Unido a ello está el desarrollo de una pudiente industria alfarera que satisface la demanda de envases.

El punto álgido de este proceso se alcanza ya en el último cuarto del I a.C., cuando una necesária producción adquiere un volumen relativamente importante y alcanza en altos porcentajes "mercados" exteriores, estando capacitada para poder abastecer satisfactoriamente, junto con las producciones de la costa sudhispana, la increíble demanda que va a generar el mercado del Norte de Europa, principalmente militar, pero también el civil oleario $\mathrm{y}$, en menor medida vinario, de Roma, ampliándose el radio de recepción de las ánforas del Guaddalquivir en el Occidente del Imperio y más allá.

En este proceso de crecimiento y consolidación de las mercancías agropecuarias sudhispanas no sólo se va 
a "cristalizar" en un elenco provincial con personalidad propia (García Vargas 2010a), sino que, en un fenómeno en buena parte contrario a éste, va a desechar la mayor parte de las formas surgidas durante estos años, que no conseguirán sobrevivir al proceso de "estandarización" que se consolida con el paso al imperio y al que hacemos alusión en el título de este trabajo. La razón principal es, como se ha dicho, que no se constituye hasta relativamente tarde un elenco estándar y plenamente establecido, sino que los alfareros del valle del Guadalquivir y, en menor medida, también los de la región gaditana, se encuentran durante unos años en proceso de "experimentación" ante la ausencia de una tradición regional consolidada que diese lugar a morfologías bien definidas para el transporte de los productos de la región. La constitución de estas morfologías regionales se haría poco a poco, imperceptible e inconscientemente, en medio de un mercado cada vez más ampliado por razones económicas y políticas. El "fermento" para este proceso serían, como se ha señalado, las ánforas del sur de Italia, tomadas como referencia, pero no directamente imitadas, tanto para las series "vinarias" como para las olearias.

No quisiéramos poner fin a estas líneas sin enfatizar la necesidad de diferenciar con claridad en las publicaciones de informes de excavación o de presentación de contextos cerámicos los tipos anfóricos presentes más allá de atribuciones genéricas, poco útiles para la investigación, del tipo "ovoide sudhispana" o "ánfora ovoide republicana". Dado el estado actual de la investigación es ya inexcusable la diferenciación entre los repertorios anfóricos oriundos de cada región del Occidente romano (Italia adriática, costa de la Ulterior, Noreste de la Penísula Ibérica, Tripolitania...). Sólo de este modo puede determinarse con ciertas garantías en cada área de consumo el peso de las importaciones de cada región. Sin la exigencia de la mayor precisión posible en las atribuciones, si no formales por lo menos de procedencia, se corre el riesgo de perpetuar un escenario marcado por la indefinición de lugares de procedencia, que amenaza con anular a efectos de interpretación histórica los loables esfuerzos realizados en la contextualización y presentación de los materiales, y presentarnos un panorama falseado o cuanto menos sumamente sesgado.

Por otra parte, la correcta clasificación y, con ella, la segura constatación de la presencia de las ánforas republicanas sudhispanas, y en concreto del valle del Guadalquivir, en sus diferentes áreas importadoras y la cuantificación de los porcentajes de presencia permitirá una valoración más ajustada del desarrollo de la economía agropecuaria del sur peninsular que si bien ya venía desarrollándose con un destacado ritmo productivo desde finales del siglo II a.C., sufre una rapidísima evolución en la segunda mitad del siglo I a.C., que llevará a que productos como el vino o el aceite béticos se conviertan al final del periodo en mercancías protagonistas del proceso de integración económica de las provincias del extremo Occidente en la red "comercial" y económica del imperio, junto a los metales de la misma procedencia.

Los cambios constantes y vertiginosos que hemos constatado en las tipologías anfóricas regionales y la enorme diversidad y líneas de desarrollo de las mismas se presentan de momento como un reflejo de contornos aún poco delimitados en un espejo arqueológico que esperamos, sin embargo, no nos devuelva una imagen en exceso distorsionada.

\section{BIBLIOGRAFÍA}

ALARCÃO, J.; CARVALHO, P.J.C. y GONÇALVES, A. (2009): Castelo da Lousa: Intervenções Arqueológicas de 1997 a 2002. Stvdia Lvsitana 5. Mérida, Museo Nacional de Arte Romano / EDIA.

ALMEIDA, R.R. (2008): Las Ánforas del Gualdalquivir en Scallabis (Santarém, Portugal). Aportación al Conocimiento de Los Tipos Minoritarios. Col. Leció Instrumenta 8. Barcelona, Publications de la Universitat de Barcelona.

- (2010): "The incorporation of the Baetican Hinterland into the Western supply during the Late Republic. A reading based on the distribution of the Guadalquivir's minority amphora types", en Carreras Monfort, C. y Morais, R. (eds.), The Western Roman Atlantic Façade. A study of the economy and trade in the Mar Exterior from the Republic to the Principat. BAR International Series 2162: 191196. Oxford.

ALMEIDA, R.R. y ARRUDA, A. M. (2005): “As ânforas de tipo Maña C em Portugal", $V$ Congresso Internacional de Estudos Fenício-Púnicos. Cerdeña.

ANTEAS, J.M.F. (1993): "Les fouilles de Malard à Narbonne. Résultats préliminaires d'un sondage sur un lit d'amphores du 1er Siécle aprés J.-C", Cahiers D'Archéologie Subaquatique XI: 67-79.

AQUILUÉ, X.; CASTANYER, P.; SANTOS, M. y TREMOLEDA, J. (2004): "Geografia del Consum de les Haltern 70. Les Àmfores Haltern 70 d'Empúries", en VV.AA., Culip VIII i les Àmfores Haltern 70, Monografies del Casc 5: 112-117. 
Girona, Museu d'Arqueologia de Catalunya / Centre d'Arqueologia Subaquàtica de Catalunya.

ARANEGUI GASCÓ, C., (ed.) (2001): Lixus. Colonia fenicia y ciudad púnico-mauritana. Anotaciones sobre su ocupación medieval. SAGVNTVM Extra 4.

- (ed.) (2005): Lixus 2. Ladera Sur. Excavaciones arqueologica marroco-españolas en la colonia fenicia. Campañas 2002-2003. SAGVNTVM Extra 6: 87-140.

ARANEGUI GASCÓ, C.; KBIRI ALAOUI, M. y VIVES-FERRANDIZ, J. (2004): "Alfares y producciones cerámicas en Mauritania occidental. Balance y perspectivas", Actas del Congreso Internacional Figlinae Baeticae. Talleres Alfareros y Producciones Cerámicas en la Bética Romana (ss.II a.C. - VII d.C.). B.A.R. International Series: 363-378. Oxford.

ARÉVALO GONZÁLEZ, A. y BERNAL CASASOLA, D. (2007): Las Cetariae de Baelo Claudia: avance de las investigaciones arqueológicas en el barrio meridional (2000-2004). Sevilla, Junta de Andalucía, Consejería de Cultura.

ARRUDA, A. M. (1996): "O Castelo de Castro Marim”, De Ulisses a Viriato, O Primeiro Milénio a.C.: 95-100. Lisboa, Instituto Português de Museus / Museu Nacional de Arqueologia.

ARRUDA, A. M. y ALMEIDA, R.R. (1998): “As ânforas da Classe 32 da Alcáçova de Santarém”, Conimbriga 37: 201-231.

- (1999): “As Importações de Vinho Itálico Para o Território Português. Contextos, Cronologias e Significado", III Table Ronde Sur la Lusitanie Romaine. Collection de la Casa de Velázquez 65: $307-$ 337. Madrid, Casa de Velázquez.

- (2001): "Importação e consumo de vinho bético na colónia romana de Scallabis", Actas del Congreso Internacional Ex Baetica Amphorae. Conservas, Aceite y Vino de la Bética en el Império Romano (Écija-Sevilla 1998) Vol II: 703-715. Écija.

ARRUDA, A.M. y PEREIRA, C. (2010): "Fusão e produção: actividades metalúrgicas em Monte Molião (Lagos), durante a época Romano-Republicana", XELB10. Actas do $7^{\circ}$ Encontro de Arqueologia do Algarve: 695-716. Silves, Câmara Municipal de Silves.

ARRUDA, A.M.; VIEGAS, C. y BARGÃO, P. (2005): "As ânforas da bética costeira na Alcáçova de Santarém”, Revista Portuguesa de Arqueologia vol. 8, $\mathrm{n}^{\circ} 1: 279-297$.

- (2006a): “Ânforas lusitanas da Alcáçova de Santarém”, Simpósio Internacional "Produção e comércio de Preparados Piscícolas durante a Proto-História e a Época Romana no Ocidente da Península
Ibérica-Homenagem a Françoise Mayet (Setúbal, Maio 2004). Setúbal Arqueológica 13: 233-252. Setúbal.

ARRUDA, A. M.; VIEGAS, C.; BARGÃO, P. y PEREIRA, R. (2006b): “A importação de preparados de peixe em Castro Marim: da Idade do Ferro à Época Romana", Simpósio Internacional "Produção e comércio de Preparados Piscícolas durante a Proto-História e a Época Romana no Ocidente da Península Ibérica-Homenagem a Françoise Mayet (Setúbal, Maio 2004). Setúbal Arqueológica 13: 153-176. Setúbal.

ARTEAGA MATUTE, O. (1985): “Excavaciones arqueológicas en el Cerro del Mar. Campaña de 1982. Una aportación preliminar al estudio estratigráfico de las ánforas punicas y romanas del yacimiento", Noticiario Arqueoloógico Hispánico 23: 197-233.

ASSKAMP, R. (2010): Haltern, Stadt Haltern am See, Kreis Recklinghausen. Römerlager in Westfalen 5. Münster.

BALDACCI, P. (1972): “Importazioni Cisalpine e Produzione Apula", Recherches sur les Amphores Romaines. Collection de l'École Française de Rome 10: 7-28. Rome.

BARBERAN, S., MALIGNAS, A., MARTÍNEZ FERRERAS, RENAUD, A., SILVEREANO, S. , GHISLAIN, V. (2009): “Un ensemble augustéen mis au jour au pied du monument corinthien de l'agglomération du Castellas (Murviel-lès-Montpellier, Hérault) ", SFECAG, Actes du congrès de Colmar 2009. Marseille : 289-318.

BAREA BAUTISTA, J.S.; BAREA BAUTISTA, J.L.; SOLÍS SILES, J. y MOROS DÍAZ, J. (2008): Figlina Scalensia. Un centro productor de ánforas Dressel 20 de la Bética, Col.lecció Instrumenta 27. Barcelona, Publications de la Universitat de Barcelona.

BARROS, L. y HENRIQUES, F. (2002): “A última fase de ocupação do Almaraz", $3{ }^{\circ}$ Encontro Nacional de Arqueologia Urbana (Almada, 1997): 295311. Almada, Monografias Arqueologia, Câmara Municipal de Almada.

BECKER, C.; CONSTANTIN, C.; DESBAT, A.; JACQUIN, L y LASCOUX, J.-P. (1986): "Le dépôt d'amphores augustéen de la rue de la Favorite à Lyon", Figlina 7: 65-89.

BELÉN DEAMOS, M. (2006): “Ánforas de los siglos VI-IV a.C. en Turdetania”, Spal 15: 217-246. http:// dx.doi.org/10.12795/spal.2006.i15.11

BELTRÁN LLORIS, M. (1970): Las Anforas Romanas en España. Zaragoza. 
- (1977): "Problemas de la morfología y del concepto histórico-geográfico que recubre la noción tipo. Aportaciones a la tipología de las ánforas béticas", Méthodes Classiques et Méthodes Formelles dans l'Étude des amphores. Collection de L'École Française de Rome 32: 97-117. Roma.

BENOIT, F. (1956): "Épaves de la cote de Provence. Typologie des Amphores", Gallia 14: 23-34.

BENQUET, L. y OLMER, F. (2002): "Les amphores", en J.M. Blázquez Martínez, C. Domergue y P. Sillières, La Loba (Fuenteovejuna, Córdoba). La Mine et le Village Minier Antiques: 295-331. Burdeos.

BENQUET, L y GRIZEAUD, J.J. (2009): "Découvertes récentes dans le quartier Saint-Roch à Toulouse (Haute-Garonne)", Actes du Congrès de la Sfecag à Colmar: 655-670. Marsella.

BERNAL CASASOLA, D. (dir.) (1998): Excavaciones arqueológicas en el alfar romano de la Venta del Carmen, Los Barrios (Cádiz): una aproximación a la producción de ánforas en la bahía de Algeciras en época altoimperia. Madrid-Cádiz.

- (ed.)(1998): Los Matagallares (Salobreña, Granada). Un centro romano de producción alfarera en el siglo III $d$. C. Salobreña.

- (1999): "Transporte de envases vacíos en época romana: a propósito de dos talleres anfóricos béticos de época alto (El Rinconcillo, Algeciras, Cádiz) y bajoimperial (Los Matagallares, Salobreña, Granada)", II Congreso de Arqueología Peninsular (Zamora, 24 al 27 de septiembre de 1996): 359364. Alcalá de Henares.

- (2007): "Vinos tarraconenses más allá de las Comunas de Hércules. Primeras evidencias en la Baetica, Lusitania y Tingitana", La producció i el comerç de les àmfores de la Provincia Hispania Tarraconensis. Homenatge a Ricard Pascual i Guasch. Monografies Museu d'Arqueologia de Catalunya 8: 319-352. Barcelona.

BERNAL CASASOLA, D.; ARÉVALO GONZÁLEZ, A.; LORENZO MARTÍNEZ, L. y AGUILERA, L. (2003): "Imitations of italic amphorae for fish sauce in roman Baetica. New evidence from the salt fish factory at Baelo Claudia", Rei Cretariae Romanae Fautorum Acta 38: 305-313. Abingdon.

BERNAL CASASOLA, D. y JIMÉNEZ-CAMINO ÁLVAREZ, R. (2004): "El taller de El Rinconcillo en la bahía de Algeciras. El factor itálico y la economía de exportación (ss. I a. C.-I d. C.)", Actas del Congreso Internacional Figlinae Baeticae. Talleres Alfareros y Producciones Cerámicas en la Bética Romana (ss. II a. C.-II d. C.). B.A.R. International Series 1266: 589-606. Oxford.
BERNAL CASASOLA. D. y SÁEZ ROMERO, A.M. (2008): "Opérculos y ánforas romanas en el Círculo del Estrecho. Precisiones tipológicas, cronológicas y funcionales", Rei Cretariae Romanae Acta 40: 455-472.

BERNAL CASASOLA, D., ROLDÁN L., BLÁNQUEZ, M. y SÁEZ, A. M. (2011): "De la producción anfórica de Carteia en época republicana. Primeras evidencias", Homenaje al profesor Antonio Caro Bellido: 65-82. Cádiz, Servicio de Publicaciones de la Universidad de Cádiz.

BERNAL CASASOLA, D. y GARCÍA VARGAS, E. (en prensa): Gades como centro de consumo entre el S. II a.C. y la antigüedad tardía. Aportaciones del registro anfórico procedente de las excavaciones en la Casa del Obispo.

BERNAL CASASOLA, D.; GARCÍA VARGAS, E. y SÁEZ ROMERO, A. (en prensa): "Ánforas itálicas en la Hispania meridional" Immensa Aequora-Ricerche archeologiche, archeometriche e informatiche per la ricostruzione dell'economia e dei commerci nel bacino occidentale del Mediterraneo" (Roma 24-26 gennaio 2011).

BERNARD, H. (2008): "Nouvelles épaves hispaniques de Corse : Sud Perduto 2 (Bonifacio) et Marina di Fiori (Porto Vecchio)", en J. Pérez Ballester e G. Pascual Berlanga (eds.), Comercio, Redistribución y Fondeaderos. La navegación a vela en el Mediterráneo.V Jornadas Internacionales de Arqueología Subacuática: 461-471. Valencia.

BERNI MILLET, P. (1998): Las ánforas de aceite de la Bética y su presencia en la Cataluña romana. Col. Leció Instrumenta 4, Barcelona, Publications de la Universitat de Barcelona.

- (2008): Epigrafía anfórica de la Bética. Nuevas formas de análisis. Col.lecció Instrumenta 29. Barcelona, Publications de la Universitat de Barcelona.

- (2011): "Tipología de la Haltern 70 bética", Ánforas romanas de Lugo (comercio romano en los Finisterrae). Traballos de Arqueoloxía 3: 80-107. Lugo.

BEZECZKY, T. (2004): "Early Roman Food Import in Ephesus: Amphorae from the Tetragonos Agora", Transport Amphorae and Trade in the Eastern Mediterranean. Monographs of the Danish Institute at Athens 5: 85-97. Aarhus.

BLAZQUEZ MARTINEZ, J.M.; DOMERGUE, C. y SILLIERES, P. (2002): La Loba (Fuenteovejuna, province de Cordoue, Espagne): la mine et le village minier antiques. Burdeos, Institut Ausonius. 
BONET ROSADO, H. FUMADÓ ORTEGA, I., ARANEGUI GASCÓ, C., VIVES-FERRÁNDIZ SÁNCHEZ,J., HASSINI, H., KBIRI ALAUI, M. (2005): "La ocupación mauritana", en C. Aranegui Gascó, C. (Ed.), Lixus 2. Ladera Sur. Excavaciones arqueologica marroco-españolas en la colonia fenicia. Campañas 2002-2003. SAGVNTVM Extra 6: 87-140. Valencia, Universidad de Valencia.

BONIFAY, M. (2004). Études sur la céramique romaine tardive d'Afrique. BAR International Series 1301. Oxford.

BOTTE, E (2009) : Salaisons et sauces de poissons en Italie du sud et en Sicile durant l'Antiquité, Collection Archéologie de l'artisanat antique, 1. Nápoles, Centre Jean Berard.

BOUBE, J. (1973-1975): "Marques d'amphores découverts à Sala, Volubilis et Banasa", Bulletin d'Archéologie Marocaine IX: 163-235. Rabat.

- (1979-1980): “Amphores prérromaines trouvées en mer au voisinage de Rabat", Bulletin d'Archéologie Marocaine 12: 163-235.

- (1987-1988): “Les amphores de Sala à 1'époque mauritanienne", Bulletin d'Archéologie Marrocaine 17: 183-208.

BUGALHÃO, J. (2001): A indústria romana de transformação e conserva de peixe em Olisipo. Núcleo arqueológico da Rua dos Correeiros. Lisboa, Insituto Português de Arqueologia.

BUSTAMANTE ÁLVAREZ, M. y MARTÍNARROYO SÁNCHEZ, D. (2004): "La producción de ánforas greco-itálicas de imitación y su evolución en la bahía gaditana durante el siglo II a. C.: los contextos de la Avenida Pery Junquera en San Fernando (Cádiz)", Actas del Congreso Internacional Figlinae Baeticae. Talleres Alfareros y Producciones Cerámicas en la Bética Romana (ss. II a. C.-VII d.C.). B.A.R. International Series 1266: 441-446. Oxford.

CALLU, J. P. y otros (1965): Thamusida I. 2eme suplemente de Mélanges de l'École Française de Rome et Athénes, Paris.

CAMPOS CARRASCO, J. (1986): Excavaciones arqueológicas en la ciudad de Sevilla. El origen prerromano y la Hispalis romana. Sevilla.

CARANDINI, A. (1981): "Sviluppo e crisi delle manifatture rurali e urbane", Società romana e produzione schiavistica, vol. II: 249-260. Roma-Bari.

CARDENETE, R.; GÓMEZ, M.T.; JIMÉNEZ, A.; LINEROS, I. y RODRÍGUEZ, I. (1989): "Excavaciones arqueológicas de urgencia en el solar de la calle Montánchez 4, Carmona (Sevilla)", Anuario
Arqueológico de Andalucía, vol III-Actividades de Urgencia: 585-591. Sevilla.

CARDOSO, G. y RODRIGUES, S. (2005): “Olaria romana do Morraçal da Ajuda (Peniche-Portugal)", Actas do Congresso a Presença Romana na Região Oeste: 83-102. Bombarral.

CARDOSO, G.; RODRIGUES, S. y SEPULVEDA, E. (2006): “A olaria romana de Peniche", Simpósio Internacional "Produção e comércio de Preparados Piscícolas durante a Proto-História e a Época Romana no Ocidente da Península Ibérica - Homenagem a Françoise Mayet (Setúbal, Maio 2004). Setúbal Arqueológica 13: 253-278. Setúbal.

CARRE, M.-B. y MATTIOLI, S.P. (2003): "Tentativo di classificazione delle anfore olearie adriatiche", Aquileia Nostra Anno LXXIV: 453-476. RomaBari.

CARRERAS MONFORT, C. (2001): "Producciones de Haltern 70 y Dressel 7-11 en las inmediaciones del Lacus Ligustinus (Las Marismas, bajo Guadalquivir)", Ex Baetica Amphorae. Conservas, aceite y vino de la Bética en el Imperio Romano Vol. 1: 419426. Écija.

- (2003): "Haltern 70: a review", Amphorae in Britain and the western Empire. Journal of Roman Pottery Studies 10: 85-91.

- (2004): "Estat de la qüestió sobre els continguts de las àmfores Haltern 70", en VV.AA., Culip VIII $i$ les Amfores Haltern 70, Monografies del Casc 5: 117119. Girona, Museu d'Arqueologia de Catalunya / Centre d'Arqueologia Subaquàtica de Catalunya.

CARRERAS MONFORT, C. y BERNI MILLET, P. (2003): “Ánforas", Astorga IV. Lucernas y ánforas, (Colección de Arqueología Leonesa I. Serie Astorga IV), León: 653-673

CARRERAS MONFORT, C. y MARIMON, P. (2004): "Tipologia d'Haltern 70 del Culip VIII. Verulamium 1908 (Haltern 70 tardana)", en VV.AA., Culip VIII i les Amfores Haltern 70, Monografies del Casc 5: 139-147. Girona, Museu d'Arqueologia de Catalunya / Centre d'Arqueologia Subaquàtica de Catalunya.

CARRERAS MONFORT, C. y MORAIS, R. (eds.) (2010): The Western Roman Atlantic façade- A study of the economy and trade in the Mar Exterior from the Republic to the Principate. BAR International Series 2162. Oxford.

CARRERAS MONFORT, C. y MORAIS, R. (2011): "Las ánforas de Lucus Augusti (Lugo)", Carreras, C., Morais, R., González E., (ed.), Ánforas romanas de Lugo, vol. 3. Consello de Lugo: 34-79. 
CARRERAS MONFORT, C. y GONZÁLEZ CESTEROS, H. (en prensa a): "Las ánforas de los primeros campamentos de Neuss (Renania, Alemania)", Primer Congreso Internacional de la SECAH (Marzo 2011). Cádiz.

- (en prensa b): “Ánforas tarraconenese para el limes germano. Una nueva visión sobre las Oberaden 74”, Cerámicas Hispanorromanas II. Cádiz.

CERDÁ I JUAN, D. (2000): Les Amfores Salseres a le Illes Balears. Col-lecció La Deixa 4. Mallorca, Monografies de Patrimoni Històric. Consell de Mallorca.

CERVERA POZO, L.; DOMÍNGUEZ BERENJENO, E. y GARCÍA VARGAS, E. (2007): "Estructuras de época romana en c/ Santa Verania 22", en E. Ferrer Albelda, A. Fernández Flores, J.L. Escacena Carrasco y A. Rodríguez Azogue (eds.), Ilipa Antiqua. De la Prehistoria a la época romana: 295-310. Alcalá del Río.

CHAVES TRISTÁN, F. (2005): "De la muerte de Sertorio al paso del Rubicón: un período oscuro para la numismática del sur hispano", La moneda al final de la República. Entre la tradició i la innovació. IX Curs d'Història monetària d'Hispània: 95-113. Barcelona, MNAC.

- (2008): "Moneda local en Hispania: ¿Autoafirmación o integración?", Iberia e Italia: modelos romanos de integración territorial. Verdolay 11: 353-378.

CHAVES TRISTÁN, F. y GARCÍA VARGAS, E. (1994): "Gadir y el comercio atlántico a través de las cecas occidentales de la Ulterior", Arqueología en el entorno del Bajo Guadiana: actas del Encuentro Internacional de Arqueología del suroeste [(celebrado en) Huelva y Niebla, 25 a 27 de febrero de 19937: 375-392. Huelva, Universidad de Huelva.

CHIC GARCÍA, G. (1995): "Roma y el mar: del Mediterráneo al Atlántico" en Guerra, exploraciones y navegación : del mundo antiguo a la edad moderna : curso de verano (U.I.M.P., Universidade de A Coruña) : Ferrol, 18 a 21 de julio de 1994 Universidade da Coruña, Servicio de Publicaciones: 55-90.

- (2001): Datos para un estudio socioeconómico de la Bética: marcas de alfar sobre ánforas olearias. Écija Sevilla.

- (2008): "Una perspectiva de la economía en el sur de Hispania durante la república romana", Iberia e Italia: modelos romanos de integración territorial. Verdolay 11: 325-352.

- (2008b): "Los saltus y las explotaciones mineras", Saltus, ¿concepto geográfico, administrativo o económico?", Boletin Arkeolan 15: 143-163.
CHIC GARCÍA, G. y GARCÍA VARGAS, E. (2004): "Alfares y producciones cerámicas en la provincia de Sevilla. Balance y perspectivas", Figlinae Baeticae. Talleres alfereros y producciones cerámicas en la Bética romana (II a. C.-VII d. C.). BAR Internantional Series 1266, vol. 2: 279-348. Oxford.

CIPRIANO, M-T y CARRE, M-B. (1989): "Production et typologie des amphores sur la côte adriatique de 1'Italie", Amphores Romaines et Histoire Économique: Dix Ans de Recherches (Actes du Colloque de Siena, 1986). Collection de L'École Française de Rome 114: 67-104. Roma.

COLLS, D., ÉTIENNE, R., LEQUÉMENT, R., LIOU, B., MAYET, F. (1977): L'Épave de Port-Vendres II et le Commerce de la Bétique à L'Époque de Claude. Archaeonautica 1. Paris, Editions du CNRS.

COMAS I SOLA, M. (1987): "Un tipus d'àmfora Dressel 1 de producció laietana”, Journades d'Arquelogie Romana. Granollers.

CONLIN, E. y ORTIZ NAVARRETE, A (en prensa): "Actividad Arqueológica Preventiva en c/ Dr. Fleming 13-15 de Carmona (Sevilla), Anuario Arqueológico de Andalucía, Actividades de Urgencia.

DAVIES, R.W. (1971): "The roman military diet", Britannia 2: 122-142.

DESBAT, A y LEMAÎTRE, S. (2001): "Les premieres importations d'amphores de Bétique à Lyon", Actas del Congreso Internacional Ex Baetica Amphorae. Conservas, Aceite y Vino de la Bética en el Império Romano (Écija-Sevilha 1998) Vol. III: 793-816. Écija.

DESBAT, A. y MARTIN-KILCHER, S. (1989): "Les amphores sur l'axe Rhône-Rhin à l'époque d'Auguste", Amphores Romaines et Histoire Économique: Dix Ans de Recherches (Actes du Colloque de Siena, 1986). Collection de L'École Française de Rome 114: 203-213. Rome.

DÍAZ GARCÍA, M. (2000): “Tipocronología de los contextos cerámicos tardo-republicanos en Tarraco", Empúries 52: 201-260. Barcelona.

DÍAZ GARCÍA, M. (2009): El Castellum dePuigpelat. Tarragona.

DÍAZ GARCÍA, M. y OTIÑA HERMOSO, P. (2003): "Valoración comercial de Tarraco: importaciones cerámicas entre el siglo III a. C. y la dinastía julio-claudia", XXVII Congreso Nacional de Arqueología, Vol. III Mundo Clásico. Bolskan-Revista de Arqueología del Instituto de Estudios Aragoneses 20: 67-82. Huesca.

DOMERGUE, C. (1969): "La campagne de Fouilles 1966 à Bolonia", X Congreso Nacional de Arqueología: 442-456. Zaragoza. 
- (1973): Belo-I. La stratigraphie. Publicaciones de la Casa de Velazquez 1. Paris.

- (1987): Catalogue des mines et des fonderies antiques de la Péninsule Ibérique. Madrid, Diffusion de Boccard. 2 vols.

- (1990): Les mines de la Péninsule Ibérique dans l'antiquité romaine. Colection de l'École Française de Rome. Rome.

DUŠANIĆ, S. (1989): “The Roman mines of Illyricum: organization and impact on provincial life", en C. Domergue (ed.), Mineria y metalurgia en las antiguas civilizaciones mediterraneas y europeas: 148156. Madrid-Toulouse.

EHMIG, U. (2010): Dangstetten IV. Die Amphoren. Untersuchungen zur Belieferuq einer Militaranlage in augusteischer Zeit und den Grundlagen archaologischer Interpretation von Fund und Befund. Forschungen und Berichte zur vor-und Frithgeschichte in Baden-wurttemberg Band 117. Stuttgart.

ÉTIENNE, R. y MAYET, F. (1995): “À propos de l'amphore Dressel 1C de Belo (Cádiz)", Melanges de la Casa de Velásquez XXX.1: 130-138.

ÉTIENNE, R. y MAYET, F. (2000): Le Vin Hispanique. Trois Clés Pour l'Économie de l'Hispanie Romaine. Paris, Diff. De Boccard.

FABIÃO, C. (1989): Sobre as ânforas do acampamento romano da Lomba do Canho (Arganil). Cadernos da UNIARQ 1. Lisboa, Instituto Nacional de Investigação Científica.

- (1993-1994): "O Azeite da Baetica na Lusitania", Conimbriga 32-33: 219-245.

- (1998): "O vinho na Lusitânia: reflexões em torno de um problema arqueológico", Revista Portuguesa de Arqueologia vol.1, nº1: 169-198.

- (1998a): O Mundo Indígena e a sua Romanizaçao na Área Céltica do Territorio Hoje Português. Tesis de Doctorado en Arqueologia presentada à la Faculdade de Letras de Universidade de Lisboa. Lisboa.

- (2001): "Sobre as mais antigas ânforas romanas da Baetica no Ocidente Peninsular", Actas del Congreso Internacional Ex Baetica Amphorae. Conservas, Aceite y Vino de la Bética en el Império Romano (Écija-Sevilla 1998) Vol. II: 665682. Écija.

- (2004a): "Arqueología militar romana da Lusitania: textos e evidências materiais", Arqueologia Militar Romana en Europa: 53-73. Segovia, Junta de Castilla y León - Universidad SEK.

- (2004b): "Centros oleiros da Lusitânia: balanço dos conhecimentos e perspectivas de investigação", $F i$ glinae Baeticae. Talleres alfareros y producciones cerámicas en la Bética romana (ss. II a.C.-VII d.C.), vol. 1: 379-410. Oxford, Archaeopress.

- (2006): "Las ánforas romanas", Munigua. La colina sagrada: 106-107. Sevilla.

- (2008): "Las ánforas de Lusitania", en D. Bernal Casasola, D. y A. Ribera i Lacomba, A. (eds.), Cerámicas hispanorromanas: un estado de la cuestión: 725-745. Universidad de Cádiz.

FABIÃO, C. e GUERRA, A. (1994): “As ocupações antigas de Mesas do Castelinho (Almodôvar). Resultados preliminares das Campanhas de 1990-92”, Actas das V Jornadas Arqueológicas da Associação dos Arqueólogos Portugueses (Lisboa, 1993) vol. 2: 275-289. Lisboa, Associação dos Arqueólogos Portugueses.

FERNÁNDEZ CACHO, S. (1994): El Campo de Gibraltar en la Antigüedad: una aproximación arqueológica a la estructura económica de un territorio integrado. Tesis de Licenciatura inédita. Sevilla.

FERNÁNDEZ CACHO, S. (1995): "Las industrias derivadas de la pesca en la provincia romana de la Bética: la alfarería de El Rinconcillo (Ageciras, Cádiz)", Spal 4: 173-214. http://dx.doi.org/10.12795/ spal.1995.i4.07

FERNÁNDEZ GÓMEZ, F.; CHASCO, R. y OLIVA, D. (1979): "Excavaciones en "El Cerro Macareno" La Rinconada. Sevilla (Cortes E-F-G. Campaña 1974)", Noticiario Arqueológico Hispánico 7: 7-93. Madrid.

FERNÁNDEZ IZQUIERDO, A. (1984): Las ánforas romanas de Valentia y de su entorno marítimo. Valencia.

FERRER ALBELDA, E. y GARCÍA FERNÁNDEZ, F.J. (2008): “Cerámica turdetana”, D. Bernal Casasola y A. Ribera i Lacomba (eds.), Cerámicas hispanorromanas: un estado de la cuestión: 201-220. Universidad de Cádiz.

FERRER ALBELDA, E. y GARCÍA VARGAS, E. (2001): "Producción y comercio de salazones y salsas saladas de pescado de la costa malagueña en épocas púnica y romana republicana", Comercio y Comerciantes en la Historia Antigua de Málaga. Siglo VIII a.C. - año 711 d.C. (II Congreso de Historia Antigua de Málaga): 547-571. Málaga, Servicio de Publicaciones Centro de Ediciones de la Diputación de Málaga.

FEVRIER, P.A. (1956): "Fouilles de la citadelle méridionale de Forum Julli (Fréjus, Var)", Gallia 14: 35-53.

FIGLINAE MALACITANAE (1997): Figlinae Malacitanae. La producción de cerámica romana en los territorios malacitanos: 61-78. Málaga. Servicio de Publicaciones de la Universidad de Málaga. 
FILIPE, V. (2008a): As ânforas do teatro romano de Lisboa. Tesis de Mestrado presentada a la Faculdade de Letras da Universidade de Lisboa. Policopiado.

- (2008b): "Importação e exportação de produtos alimentares em Olisipo: as ânforas romanas da Rua dos Bacalhoeiros", Revista Portuguesa de Arqueologia vol 11. 2: 301-324.

FINGERLIN, G. (1986): Dangstetten I. Stuttgart.

- (1998): Dangstetten II. Katalogue der Funde. Stuttgart

FOUET, G. (1958): "Pouits funéraires d'Aquitaine: Vieille-Toulouse, Montmaurin", Gallia 16: 115-196.

FREED, J. (1996): "Early roman amphoras in the collection of the museum of Carthage", Echos $d u$ monde classique / Classical Views 15.1: 119-156.

FREED, J. (2000): "Adoption of the form of the Koan Amphora to the production of Dressel 2-4 Amphoras in Italy and Northeastern Spain", $R C R F$ Acta 36: 459-466. Abingdon.

GARCÍA FERNÁNDEZ, M. (2004): Memoria Intervencion Arqueológica de Urgencia. Saneamiento integral del Aljarafe. Colector margen derecha. Inédito.

GARCÍA FERNÁNDEZ, F.J. y FERRER ALBELDA, EDUARDO (2010): "Das turdetanische Emporion Spal. Der punische Handelsverkehr in vorrömischen Sevilla (5.-2. Jh. v. Chr.)", Madrider Mitteilungen 52: 333-372.

GARCÍA FERNÁNDEZ, F.J. y GARCÍA VARGAS, E. (2010): "Entre gaditanización y romanizacion: repertorios cerámicos, alimentación e integración cultural en Turdetania (siglos III-I a.C.)", en C. Mata Parreño, G. Pérez Jordá y J. Vives-Ferrándiz Sánchez (eds.), De la Cü̈na a la Taula. IV Reunió d'economia en el primer mil.leni: 115-134. Valencia.

GARCÍA VARGAS, E. (1996): “La Producción anfórica en la Bahía de Cádiz durante la República como índice de romanización", Habis 27: 49-62.

- (1998): La Producción de Ánforas en la Bahía de Cádiz en Época Romana. (Siglos II a. C. - IV d. C.). Écija, Edtorial Sol.

- (2000): “Ánforas romanas producidas en Hispalis. Primeras evidencias arqueológicas", Habis 31: 235-260.

- (2001): "La producción de ánforas "romanas" en el sur de Hispania. República y Alto Império, Actas del Congreso Internacional Ex Baetica Amphorae. Conservas, Aceite y Vino de la Bética en el Império Romano (Écija-Sevilla 1998): 57-174. Écija, Editorial Sol.

- (2003): "Las producciones de la figlina. Ánforas", en A. Vázquez Labourdette (ed.), Arqueología y Reabilitación en el Parlamento de Andalucía. Investigaciónes Arqueológicas en el Antiguo Hospital de las Cinco Llagas de Sevilla: 200-219. Sevilla.
- (2004a): "Las ánforas del vino bético altoimperial: formas, contenidos y alfares a la luz de algunas novedades arqueológicas", Actas del Congreso Internacional Figlinae Baeticae. Talleres Alfareros y Producciones Cerámicas en la Bética Romana (ss. II a. C.-VII d.C.). BAR International Series 1266: 507-514. Oxford.

- (2004b): "El vino de la Bética altoimperial y las ánforas. A propósito de algunas novedades epigráficas", Gallaecia 23: 117-134.

- (2009): "Las ánforas republicanas de Hispalis (Sevilla) y la"cristalización" del repertorio anfórico provincial", en R.Cruz-Auñon Briones y E. Ferrer Albelda (eds.), Estudios de Prehistoria y Arqueología en Homenaje a Pilar Acosta Martínez: 437-464. Sevilla: Servicio de Publicaciones de la Universidad de Sevilla.

- (2010): "Formal Romanisation and Atlantic projection of amphorae from the Guadalquivir Valley", en C. Carreras Monfort y R. Morais (eds.), The Western Roman Atlantic Façade. A study of the economy and trade in the Mar Exterior from the Republic to the Principat. BAR Internantional Series 2162: 55-65. Oxford.

- (2010b): "Ánforas béticas de época augusteo-tiberiana: Una retrospectiva", en A.M. Niveau de Villedary y Mariñas y V. Gómez (coords.), Las necrópolis de Cádiz: apuntes de arqueología gaditana en homenaje a J.F. Sibón Olano: 581-624. Universidad de Cádiz, Servicio de Publicaciones.

- (en prensa): "Producciones anfóricas tardorrepublicanas y tempranoaugusteas del valle del Guadalquivir. Formas y rimtos de la romanización en Turdetania a través del artesanado cerámico", Cerámicas Hispanorromanas II. Cádiz.

GARCÍA VARGAS, E. y BERNAL CASASOLA, D. (2008): “Ánforas de la Bética", en D. Bernal Casasola, D. y A. Ribera i Lacomba, A. (eds.), Cerámicas hispanorromanas: un estado de la cuestión: 661-687. Universidad de Cádiz.

GARCÍA VARGAS, E.; FERRER ALBELDA, E. y GARCÍA FERNÁNDEZ, F.J. (2008): "La romanización del Bajo Guadalquivir: ciudad, territorio y economía (siglos II-I A.C.)", Mainake 30: 247-270.

GARCÍA VARGAS, E. y GARCÍA FERNÁNDEZ, F.J. (2009): "Romanización y consumo: cambios y continuidades en los contextos cerámicos de Hispalis en épocas turdetana y romano-republicana", Spal 18: 131-165. http://dx.doi.org/10.12795/spal.2009. i18.08

GARCÍA VARGAS, E. y LÓPEZ ROSENDO, E. (2008): "El alfar de Rabatún (Jerez de la Frontera, 
Cádiz) y la producción de ánforas y cerámica común en la campiña del Guadalete en época altoimperial romana", Spal 17: 281-313. http://dx.doi. org/10.12795/spal.2008.i17.12

GARCÍA Y BELLIDO, A. (1972): "Marca de M.Tuccius Galeo hallada en Cádiz", Hommage a Fernand Benoit vol. III: 143-144. Bordighera, Institut International d'Etudes Ligures.

GAUTHIER, B. y JONCHERAY, J.P. (1993): “Le gisement C du Cap Gros", Cahiers d'Archéologie Subaquatique XII: 167-183.

GEBELLÍ BORRAS, P (2008): "La dinámica comercial en época augustal: estudi de les àmfores dels nivells augustals de les intervencions al teatre romà de Tàrraco (UE 2311 i 3120)", Pyrenae. Revista de Prehistòria i Antiguitat de la Mediterrrània Occidental 39, 2: 47-69.

GEBELLÍ BORRAS, P. y DÍAZ, M. (2001): "Importaciones béticas en Tarraco en contextos pre-augusteos", Actas del Congreso Internacional Ex Baetica Amphorae. Conservas, Aceite y Vino de la Bética en el Império Romano (Écija-Sevilha 1998): 13491355. Écija.

GIL DE LOS REYES, M.S.; LINEROS, R.; CARDENETE, R.; GÓMEZ, T. y RODRÍGUEZ, I. (1987): "El espacio extramuros de Carmona romana (Sevi1la) y su uso industrial. El horno de la c/ Doctor Fleming no 25", Annuario Arqueológico de Andalucía 1987 III. Actividades de Urgencia: 586-590. Sevilla.

GÓMEZ SAUCEDO, M.T. (en prensa): “Actividad Arqueológica Preventiva en el solar de C/ Montánchez n 15 de Carmona (Sevilla)", Anuario Arqueológico de Andalucía 2006 III. Actividades de Urgencia.

GONZÁLEZ CESTEROS, H. (2010): “Ánforas del foro tardorrepublicano de Valeria. Una aproximación", Boletín Ex oficina Hispana 2: 43-44. Madrid.

- (en prensa): "Ánforas del Foro tardorrepublicano de Valeria", I Congreso Internacional de la SECAH.

GONZÁLEZ CESTEROS, H. y TREMMEL, B. (en prensa): “Aceite, vino y salazones hispanos en Oberaden”, Coloquio Internacional De vino et oleo hispaniae. Murcia.

GONZÁLEZ-RUIBAL, A. (2004): "Facing two seas: mediterranean and athlantic contacts in the NW of Iberia", Oxford Journal of Archaeology 23(3): 287-317.

GONZÁLEZ-RUIBAL, A.; RODRÍGUEZ MARTÍNEZ, R.; ABOAL FERNÁNDEZ, R. y CASTRO HIERRO, V. (2007): “Comercio mediterráneo en el castro de Montealegre (Pontevedra, Galicia). Siglo II a.C. - inicios del siglo I d.C.", Archivo Español de Arqueología 80: 43-74.
GOUDINEAU, C. y BRENTCHALOFF, D, (eds.) (2009): Le camp de la flotte d'Agrippa à Fréjus: les fouilles du quartier de Villeneuve (1979-1981). París.

GRAN-AYMERICH, J. (1991): Malaga phénicienne et punique. Recherches franco-espagnoles 19811988. París.

GUERRERO AYUSO, V. (1987): La colonia de Sant Jordi (Mallorca). Estudis d'Arqueologia i Epigrafia. Palma de Mallorca, Publications del Centre d'Estudis Gabriel Alomar.

HESNARD, A. (1980): "Un dépôt augustéen d'amphores à la Longarina, Ostie", Memoirs of the American Academy in Rome XXXVI: 141-163. Roma.

- (1998): "S.C.G: (nº 566) et les Dr.1C-Dr.12 de Bétique", Blanc Bijon, V. y otros, Recueil de timbres sur amphores romaines II: 291-293. Aix-en-Provence.

HESNARD, A., RICO, M., ARTHUR, P., PICON, M., TCHERNIA, A. (1989): "Aires de production des gréco-italiques et des Dr.1", Amphores Romaines et Histoire Économique: Dix Ans de Recherches (Actes du Colloque de Siena, 1986). Collection de L'École Française de Rome 114: 21-65. Roma.

IZQUIERDO DE MONTES, R. (2007): “Fortissimum Oppidum. Investigaciones en la muralla romana de Alcalá del Río", en E. Ferrer Albelda, A. Fernández Flores, J.L. Escacena Carrasco y A. Rodríguez Azogue (eds.), Ilipa Antiqua. De la Prehistoria a la época romana: 193-209. Alcalá del Río.

IZQUIERDO PERAILLE, I., KBIRI ALAUI, M., BONET ROSADO, H. y MILOU, B. (2001): "Las fases púnico-mauritanas I (175-150 a 80/50 a. C) y II (80/50 a. C.-15 d. C.)", en C. Aranegui Gascó (ed.), Lixus. Colonia Fenicia y Ciudad Púnico-Mauritana. Anotaciones Sobre Su Ocupación Medieval. SAGVNTVM EXTRA 4: 141-168. Valencia.

KBIRI ALAUI, M. (2007): Revisando Kuass (Asilah, Marruecos). Telleres cerámicos en un enclave fenicio, púnico y mauritano, Saguntum Extra-7. Valencia.

LAGÓSTENA BARRIOS, L. (1996a): Alfarería romana en la Bahía de Cádiz. Cádiz.

- (1996b): "Explotación del salazón en la Bahía de Cádiz en la Antigüedad: aportación al conocimiento de su evolución a través de la producción de las ánforas Maña C", Florentia Iliberritana: 141-169.

LAGÓSTENA BARRIOS, L. y BERNAL CASASOLA, D. (2004): "Alfares y producciones cerámicas en la provincia de Cádiz. Balance y 
perspectivas", Figlinae Baeticae: talleres alfareros y producciones cerámicas en la Bética romana (ss. II a.C.-VII d.C.): actas del Congreso Internacional (Cádiz, 12-14 de noviembre de 2003). BAR International Serie 1266, vol. 1: 39-123. Oxford.

LAGOSTENA, L y MATA, E. (2007): “Oleicultura romana en la cuenca del Guadalete. La almazara de Fuente Grande, Alcalá del Valle", I Congreso de la Cultura del Olivo: 157-176. Jaén.

LAMBOGLIA, N. (1955): "Sulla cronologia delle amphore romane di etá republicane (II-I secolo a.C.)", Revista de Studi Liguri 22: 243-295.

LEMAÎTRE, S.; DESBAT, A. y MAZA, G. (1998): "Les amphores du site du "sanctuaire de Cybèle" à Lyon. Étude preliminaire", SFECAG Actes du Congrés d'Istres: 45-59.

LILLO CARPIO, P. (1986): "Habitats singulares en la Edad Antigua. La Cueva de Las Peñas Blancas en las Lomas de la Carrasca (Cartagena)", Anales de Prehistoria y Arqueología 2: 121-129.

LIOU, B. (1990): "Le commerce de la Bétique au 1er siècle de nocle ère. L'épave Lavezzi 1", Archaeonautica 10: 125-155. París.

- (2001): "Las ánforas béticas en el mar. Les épaves en Méditerranée à cargaison d'amphores de Bétique". Actas del Congreso Internacional Ex Baetica Amphorae. Conservas, Aceite y Vino de la Bética en el Império Romano (Écija-Sevilla 1998) Vol. III: 1061-1111. Écija.

LIOU, B. y DOMERGUE, C. (1990): “Lecommerce de la Bétique au Ier siècle de notre ère. L'épave SudLavezzi 2 (Bonifacio, Corse du sud)", Archaeonautica 10: 11-121. París.

LOESCHCKE, S. (1909): Ausgrabungen bei Haltern. Die Keramische Funde, Mitteilungen der Altertums-Kommission für Westfalen 5. Münster.

LOESCHKE, S. (1942): "Die römische und die belgische Keramik", C. Albrecht (ed.), Das Römerlager in Oberaden und das Uferkastell in Beckinghausen an der Lippe 11.2: 7-148. Dortmund.

LÓPEZ MULLOR, A. y MARTÍN MENÉNDEZ, A. (2007): "Tipologia i datació de les àmfores tarraconenses produïdes a Catalunya", La producció i el comerç de les àmfores de la Provincia Hispania Tarraconensis. Homenatge a Ricard Pascual $i$ Guasch. Monografies Museu d'Arqueologia de Catalunya 8: 33-94. Barcelona.

- (2008): "Las ánforas de la Tarraconense", en D. Bernal Casasola y A. Ribera i Lacomba (eds.) Cerámicas hispanorromanas: un estado de la cuestión: 689-724. Universidad de Cádiz.
LÓPEZ MÁLAX-ECHEVARRÍA, A. (1971-1973): "Malaca romana (yacimientos inéditos)", Malaka 6: 50-60.

LÓPEZ ROSENDO, E. (2008): "El alfar romano altoimperial del Jardín de Cano (El Puerto de Santa María, Cádiz, España), en el contexto económico de "Gades", Revista de Historia de El Puerto 41: 3974. Puerto de Santa María.

- (2010): "Los talleres alfareros del Jardín de Cano (El Puerto de Santa María, Cádiz). La producción anfórica de Gades en torno al cambio de era", Rei Cretariae Romanae Fautorum Acta 41: 411-419. Bonn.

LOUGHTON, M.E. (2003): "The distribution of republican amphorae in France", Oxford Journal of Archaeology 22, 2: 177-207.

LUZÓN NOGUÉ, J. Ma . (1973): Excavaciones en Itálica. Estartigrafía en el Pajar de Artillo (campaña 1970) Excavaciones Arqueológicas en España 78, Madrid.

MANACORDA, D. (1988): "Per uno studio dei centri produttori delle anfore Brindisine", La Puglia in età republicana: 91-108. Galatina.

- (2001): "Le fornaci di Giancola (Brindisi): archeologia, epigrafia, archimetria”, en F. Laubenheimer (ed.), 20 ans de recherches à Sallèles d'Aude di Fanette: 229-240. Sallèles d'Aude.

MAÑÁ, J. Ma . (1951): "Sobre la tipología de las ánforas púnicas", en Crónica del VI Congreso del Sudeste Español, Alcoy 1950. Cartagena: 203-21.

MARÍN DÍAZ, M.A. (1988): Emigración, colonización y municipalización en la Hispania Republicana. Universidad de Granada.

MARLIÈRE, E. (2002). L'outre et le tonneau dans l'Occident romain. Montagnac.

MÁRQUEZ VILLORA, J.C. (1999): El Comercio Romano en el Portus Ilicitanus. El Abastecimiento Exterior de Productos Alimentarios (Siglos I a.C.-V. d.C.). Alicante, Publicaciones de la Universidad de Alicante.

MÁRQUEZ VILLORA, J.C. y MOLINA VIDAL, J. (2001): El Comércio en el Territorio de Ilici. Epigrafia, importación de alimentos y relación com los mercados mediterráneos. Alicante, Publicaciones de la Universidad de Alicant.

MARQUÉZ VILLORA, J.C. y MOLINA VIDAL, J. (2005): Del Hibervs a Carthago Nova. Comercio de alimentos y epigrafia anfórica grecolatina. Collecció Instrumenta 18. Barcelona, Publicacions de la Universitat de Barcelona.

MARTIN-KILCHER, S. (1987): Die römischen Amphoren aus Augst und Kaiseraugst. Vol. I. Augst. 
— (1993): “Amphoren der späten Republik und frühen Kaiserzet in Karthago", Mitteilungen des Deutsches Archäologischen Instituts, Römische Abteilung 100: 269-320. Roma.

- (1994): Die römischen Amphoren aus Augst und Kaiseraugst. Vol. II y III. Augst.

- (1999): Colaboración en C. Schucany, C.; Berger, L.; Paunier, D. (Hrsg.) Römische Keramik in der Schweiz. Antiqua 31.

- (2003): "Wein, Olivenöl, Fischsauce. Amphoren aus den stratifizierten Befunden der 1. und 2. Holzbauperiode", Zur Frühzeit von Vindonissa: 351 360. Brugg.

MARTÍN MENÉNDEZ, A. (2008): “Àmfores tarraconenses i bétiques em els dereclites de mitjan segle I a.C. a la costa catalana", SFECAG (Actes du congres de l'Escala-Empuries). Les productions ceramiques en hispanie tarraconaise (IIe siecle avant j.C.-VIIe siecle apres j.-C.). Actualite des recherches ceramiques: 103-127.

MAS GARCÍA, J. (1985): "Excavaciones en el yacimiento submarino de San Ferreol", VI Congreso Internacional de Arqueología Submarina (Cartagena, 1982): 189-224. Cartagena.

MATALOTO, R. (2008): "O Castelo dos Mouros (Graça do Divor, Évora): a arquitectura "ciclópica" romana e a romanizaçao dos campos de "Liberalitas Iulia Ebora", Revista Portuguesa de Arqueologia Vol. 11, $\mathrm{N}^{\circ} 1$ : 123-147.

MAYET, F. y SILVA, C.T. (1998): L'atelier d'amphores de Pinheiro (Portugal). París.

- (2002): L'atelier d'amphores de Abul (Portugal). París.

Mc CANN. (1987): The roman Port and Fishery of Cosa. Princeton.

MERCANDO, L. (1975-1981): "Rellito di nave romana presso Ancona", Forma Maris Antiqui XIXII: 69-78.

MIRÓ, J. (1988): La producción de ánforas romanas en Catalunya. Un estudio sobre el comercio del vino de la Tarraconense (siglos I $a C-I d C$ ). BAR Internantional Series 473. Oxford.

MOLINA VIDAL, J. (1995): “Las ánforas Lomba do Canho 67. Aportaciones al estudio de un nuevo tipo: difusión y valoración económica", Actas del XXII Congreso Nacional de Arqueología: 419-424. Vigo.

- (1997): La dinámica comercial romana entre Italia e Hispania Citerior. Alicante.

- (2001): "Las primeras exportaciones béticas en el Mediterráneo occidental", Actas del Congreso Internacional Ex Baetica Amphorae. Conservas,
Aceite y Vino de la Bética en el Império Romano (Écija-Sevilla 1998) Vol. II: 637-645. Écija.

- (2002): "La irrupción de Hispania en los movimientos socioeconómicos del Mediterrâneo occidental durante las Guerras Civiles", Gérion: 20: 281-306.

MORAIS, R. (2004): "Bracara Augusta: um pequeno Testaccio de ânforas Haltern 70. Consideraçoes e problemáticas de estudo", Figlinae Baeticae, Talleres Alfareros y Producciones Cerámicas en la Bética Romana (ss. II a.C.-VII d.C.). BAR International Series 1266, II: 545-566. Oxford.

- (2004b): "Problemàtiques i noves perspectives sobre les àmfores ovoides tardo-republlicanes. Les àmfores ovoides de producció lusitana", en VV.AA., Culip VIII $i$ les Amfores Haltern 70. Monografies del Casc 5: 36-40. Girona, Museu d'Arqueologia de Catalunya / Centre d'Arqueologia Subaquàtica de Catalunya.

- (2005): Autarcia e comércio em Bracara Augusta, Bracara Augusta. Excavações Arqueológicas 2. 2 vols. Braga.

- (2007a): "Ânforas da Quinta da Ivanta. Um pequeno "habitat "mineiro em Valongo", Conimbriga XLVI: 267-280.

- (2007b): “Ânforas tipo urceus de produção bética e produções regionais e locais do NW peninsular", Actas del Congresso, Cetariae. Salgas y Salazones de Pescado en Occidente durante la Antigüedad (Cádiz, 7-9 de noviembre de 2005)". BAR International Series 1686: 401-415. Oxford.

- (2008): "Novos dados sobre as ânforas vinarias béticas de tipo urceus", Spal 17: 267-280. http:// dx.doi.org/10.12795/spal.2008.i17.11

- (2010a): “Capítulo 7.5-Ânforas", en J. de Alarcão, P.C. Carvalho y A. Gonçalves (coords.), Castelo da Lousa-Intervenções Arqueológicas de 1997 a 2002. Stvdia Lvsitana 5: 181-218. Mérida, Museo Nacional de Arte Romano / Edia.

- (2010b): "Was there a true Atlantic vocation among the first emperors", en C. Carreras Monfort y R. Morais (eds.), The Western Roman Atlantic Façade. A study of the economy and trade in the Mar Exterior from the Republic to the Principat. BAR International Series 2162: 259-260. Oxford.

MORAIS, R. y FABIÃO, C. (2007): "Novas produções de fabrico lusitano: problemáticas e importância económica", Cetariae 2005. Salsas y Salazones de Pescado en Occidente durante la Antigüedad", BAR International Series 1686: 127-133. Oxford.

MORET, P. y CHAPA BRUNET, T. (2004): Torres, atalayas y casas fortificadas: explotación y control 
del territorio en Hispania (s. III a. de C.-s. I d. de C.). Jaén, Universidad de Jaén.

MORÍN DE PABLOS, J; ALMEIDA, R.R.; BARROSO CABRERA, R. y LÓPEZ FRAILE, F. (2010): “El yacimiento de Pozo Sevilla (Alcázar de San Juan, Ciudad Real) ¿Un ejemplo de casa torre en la Mancha?", en V. Mayoral Herrera y S. Celestino Péres (ed.), Los paisajes rurales de la romanización: arquitectura y explotación del territorio (Museo Arqueológico Provincial de Badajoz, 27 y 28 de octubre de 2008): 287-322. Madrid, Ergástula.

NAVEIRO LÒPEZ, J. L. (1986): “El comercio marítimo en el NO durante la época romana a través de las ánforas", Revista de Arqueología 57: 40-55.

- (1991): El comercio antiguo en el NW Peninsular. La Coruña.

NIVEAU DE VILLEDARY Y MARIÑAS, A.M. (2002): "Las ánforas turdetanas del tipo Pellicer-D. Ensayo de clasificación", Spal 11: 233-252. http:// dx.doi.org/10.12795/spal.2002.i11.12

NIVEAU de VILLEDARY Y MARIÑAS, A.M. y BLANCO JIMÉNEZ, F.J. (2007): “Continuedad púnica en la Gades republicana. La producción vascular del horno de la calle Troilo", Spal 16: 195-224. http:// dx.doi.org/10.12795/spal.2007.i16.10

NOLLA BRUFAU, J-M. (1974): “Las ánforas romanas de Ampurias", Ampurias 36-37: 147-197.

OREN-PASCAL, M. y BERNAL CASASOLA, D. (2001): “Ánforas sudhispánicas en Caesarea Marítima, un ejemplo de importación de vino, aceite y conservas de pescado béticas en Iudaea", Actas del Congreso Internacional Ex Baetica Amphorae. Conservas, Aceite y Vino de la Bética en el Império Romano (Écija-Sevilla 1998) Vol. III: 989-1013. Écija.

PALAZZO, P. (1988): “Aspetti tipologici della produzione di anfore brindisine", La Puglia in età republicana: 109-117. Galatina.

PALAZZO, P. (1989): "Le anfore di Apani (Brindisi)", Amphores Romaines et Histoire Économique: Dix Ans de Recherches (Actes du Colloque de Siena, 1986). Collection de L'École Française de Rome 114: 548-553. Roma.

PANELLA, C. (1973): “Appunti su un gruppo di anfore della prima, media e tarda età Imperiale", Ostia III: Le terme del Nuotatore: scavo dell'ambiente V et di un saggio dell'area. Studi miscellenei 21: 460-633

PASCUAL BERLANGA, G. y RIBERA I LACOMBA, A. (2001): "El consumo de productos béticos en Valentia y su entorno: la continuidad de una larga tradición", Actas del Congreso Internacional Ex Baetica Amphorae. Conservas, Aceite y Vino de la
Bética en el Império Romano (Écija-Sevilla 1998), Vol. II: 565-576. Écija.

PARREIRA, J. C. (2009): As ânforas romanas de Mesas do Castelinho. Tesis de Mestrado presentada a la Faculdade de Letras de la Universidad de Lisboa. Inédita.

PEACOCK, D. P. S. \& WILLIAMS, D. F. (1986): Amphorae and the roman economy. An Introductory Guide. London, Longman.

PELLICER CATALÁN, M. (1978): “Tipología y cronología de las ánforas prerromanas del Guadalquivir según el Cerro Macareno (Sevilla)", Habis 9: 365-400.

PEÑA CERVANTES, Y. (2010): Torcularia : la producción de vino y aceite en Hispania. Tarragona: Institut Catalá d'Arquelogia Clàssica.

PEÑA SANTOS, A. De La (1986): Yacimiento galaicoromano de Santa Trega (A Guarda, Pontevedra). Campaña de 1983. Arqueoloxía / Memorias 5. Santiago de Compostela.

PÉREZ MACÍAS, J.A. y DELGADO DOMÍNGUEZ, A. (2007): "Los metalla de Riotinto en época julio-claudia”, en J.A. Pérez Macías y A. Delgado Domínguez (eds.), Las minas de Riotinto en época julio-claudia: 37-183.Huelva, Universidad de Huelva/Fundación Riotinto.

- (2011): "El castellum de El Castillejo (El Campillo, Huelva). La explotación minera de época romano-republicana", en J.A. Pérez Macías, A. Delgado Domínguez, J.M. Pérez López y F.J. García Delgado (eds.), Riotinto. Histoira Patrimonio Minero y Turismo Cultural: 47-73. Huelva, Universidad de Huelva/Fundación Riotinto.

PÉREZ MACÍAS, J.A.; BUSTAMENTE ÁLVAREZ, M; MARTINS, A. y RIVERO, J.L. (2009): “Ânforas romanas da "Casa do Procurador" (Aljustrel). Hábitos de consumo nos metalla de Vipasca”, Vipasca. Arqueologia e História n ${ }^{\mathrm{o}} 3$, 2a série: 13-26. Aljustrel, Câmara Municipal de Aljustrel.

PÉREZ SUÑÉ, J. M. y REVILLA CALVO, V. (2001): "Las producciones béticas y el consumo urbano: Iluro y su territorio", Actas del Congreso Internacional Ex Baetica Amphorae. Conservas, Aceite y Vino de la Bética en el Imperio Romano (Écija-Sevilla 1998) Vol. II: 593-605. Écija.

PIMENTA, J. (2005): As Ânforas Romanas do Castelo de São Jorge (Lisboa). Trabalhos de Arqueologia 26. Lisboa, Instituto Português de Arqueologia.

PIMENTA, J.; MENDES, H. y ALMEIDA, R.R. (en prensa): "Ânforas romanas da estação arqueológica de Alto dos Cacos - Almeirim". 
PIMENTA, J., SEPÚLVEDA, E., FARIA, J. C. y FERREIRA, M. (2006): "Cerâmicas romanas do lado ocidental do castelo de Alcácer do Sal, 4: ânforas de importação e de produção lusitana", Revista Portuguesa de Arqueologia 9, 2: 299-316.

PONSICH, M. (1969): "Fours de potiers puniques en Maurétaine Tingitane", X Congreso Nacional de Arquologia: 270-279. Zaragoza.

PUIG, A. (2004): “Tipologia de les Àmfores Haltern 70 i Produccions Similars. Evolució de les Haltern 70", en VV.AA., Culip VIII i les Amfores Haltern 70. Monografies del Casc 5: 23-32. Girona, Museu d'Arqueologia de Catalunya / Centre d'Arqueologia Subaquàtica de Catalunya.

QUARESMA, J. C. y CALAIS, C. (2005): "S. Pedro (Coruche): novos dados para o processo de romanização do vale do Sorraia na época augustana e júlio-cláudia”, Revista Portuguesa de Arqueologia 8.2: 429-447.

RAMBLA TORRALVO, J.A. y MAYORGA MAYORGA, A. (1997): "Hornos de época altoimperial en la calle Carretería, Málaga", Figlinae Malacitanae. La producción de cerámica romana en los territorios malacitanos: 61-78. Málaga. Servicio de Publicaciones de la Universidad de Málaga.

RAMÓN TORRES, J. (1994): Las ánforas fenicio-púnicas del Mediterráneo central y occidental, Col. lecció Instrumenta 2. Barcelona, Publications de la Universidad de Barcelona.

- (2004): "La producción anfórica en época feniciopúnica”, Actas del XVI Encuentros de Historia y Arqueología. Las Industrias Alfareras y Conserveras Fenicio Púnicas de la Bahía de Cádiz: 101-130. Ayuntamiento de San Fernando / Publicaciones CajaSur, Córdoba.

REMESAL RODRÍGUEZ, J. (1977-78): “Economía oleícola bética. Nuevas formas de análisis", AEspA 1977-78: 87-142.

REVILLA CALVO, V. (1995): Producción cerámica, viticultura y propiedad rural en Hispania Tarraconensis (siglos I $a C$ - III $d C$ ). Barcelona.

- (2010): "Cultura material y poblamiento en el territorio de Tarraco: los contextos cerámicos de la villa del Vilarenc (Calafell)", en V. Revilla Calvo y M. Roca (eds.), Contextos ceràmics i cultura material d'època augustal a l'occident romà (Actes de la reunió celebrada a la Universitat de Barcelona els dies 15 i 16 d'abril de 2007): 198-220. Barcelona, Universitat de Barcelona / Institut Català d'arqueologia clàssica / Museu d'arqueologia de Catalunya-Empúries.
REVILLA CALVO, V. y ROCA, M. (eds.) (2010): Contextos ceràmics $i$ cultura material d'època augustal a l'occident romà (Actes de la reunió celebrada a la Universitat de Barcelona els dies $15 i$ 16 d'abril de 2007). Barcelona, Universitat de Barcelona/Institut Català d'arqueologia clàssica/Museu d'arqueologia de Catalunya-Empúries.

RIBERA I LACOMBA, A. (2010): "Los materiales de época augustea de Valentia: símbolo de una etapa precaria o muestra del inicio del renacer de la ciudad", en V. Revilla Calvo y M. Roca (eds.), Contextos ceràmics i cultura material d'època augustal a l'occident romà (Actes de la reunió celebrada a la Universitat de Barcelona els dies 15 i 16 d'abril de 2007): 262-292. Barcelona, Universitat de Barcelona / Institut Català d'arqueologia clàssica / Museu d'arqueologia de Catalunya-Empúries.

RIBERA LACOMBA, A. y RIPOLLÉS ALEGRE, P. P. (1977): "Ánforas de Benicarló y su zona costera", Cuadernos de Prehistoria y Arqueologia Castellonenses 4: 159-174.

RIZZO, G. (2003): Instrumenta Urbis. 1, Ceramiche fini da mensa, lucerne ed anfore a Roma nei primi due secoli dell'Impero. Collection de l'École Française de Rome 307, Roma.

RODRÍGUEZ RODRÍGUEZ, I. (2001): "Las áreas artesanales: los alfares", Carmona Romana. Actas del II Congreso de Historia de Carmona (Carmona, 29 septiembre-2 octubre 1998): 294-311.

RUIZ DE ARBULO, J.; MAR, R.; ROCA ROUMENS, M. y DÍAZ AVELLANEDA, M. (2010): "Un contexto cerámico de fines del siglo I a.C. como relleno constructivo de un almacén portuario localizado bajo el teatro de Tarragona", en V. Revilla Calvo y M. Roca (eds.), Contextos ceràmics i cultura material d'època augustal a l'occident romà (Actes de la reunió celebrada a la Universitat de Barcelona els dies 15 i 16 d'abril de 2007): 222-260. Barcelona, Universitat de Barcelona / Institut Català d'arqueologia clàssica / Museu d'arqueologia de Catalunya-Empúries.

RUIZ MATA, D. y CÓRDOBA, I. (1999): “Los hornos turdetanos del Cerro Macareno. Cortes H.I y H.II", XXIV Congreso Nacional de Arqueología (Cartagena 1997) vol. 3: 95-105. Murcia.

SÁEZ FERNÁNDEZ, P., TINOCO MUÑOZ, J., GARCÍA VARGAS, E. y GARCÍA-DILS DE LA VEGA, S. (2001): "Excavación arqueológica de urgencia en el alfar romano de Las Delicias (Écija, Sevilla),1997", Anuario Arqueológico de Andalucía vol. III: 562-575. Sevilla. 
SÁEZ ROMERO, A.M. (2008): La producción cerámica en Gadir en época tardopúnica (siglos -III/-I). BAR Internantional Series 1812. Oxford.

SCHÖNBERGER, H y SIMON, H-G. (1976): Das augusteische Römerlagern Rödgen. Die Funde aus dem Frühkaiserzeitlichen Lagern Rödgen, Friedberg und Bad Nauheim, Limesforschungen XIV. Berlín.

SCHNURBEIN, S. von. (1981): "Untersuchungen zur Geschichte der römischen Militäranlagen an der Lippe", Berichte der Römisch-Germanischen Kommission 62: 5-101. Frankfurt.

SILVA, C. T. (1996): "Produção de ânforas na área urbana de Setúbal: a oficina romana do largo da Misericórdia", Ocupação romana dos estuarios do Tejo e do Sado: 43-54. Seixal, Câmara Municipal do Seixal.

SOTOMAYOR MURO, M. (1969): "Hornos romanos de ánforas en Algeciras", X Congreso Nacional de Arqueología: 389-399. Zaragoza.

STEFANO, A. De (2008): Un contesto ceramico di età repubblicana e primo/medio imperiale dall'area delle due domus. Herdonia X, Ricerche Archeologice a Herdonia: 45-144. Puglia, Edipuglia.

SOUSA, E. y ARRUDA, A. M. (2010): “A gaditanização do Algarve”, Mainaké XXXII (II): 951-974.

TCHERNIA, A. (1968-70): "Premiers résultats des fouilles de juin 1968 sur l'épave 3 de Planier", Études Classiques III: 51-82.

- (1971): Les Amphores vinaires de Terraconaise et leur exportation au debut de l'Empire", Archivo Español de Arqueologia 44: 38-85.

- (1986): Le Vin de l'Italie Romaine. Essai d'Histoire Economique d'Aprés les Amphores. Roma, École Française de Rome.

- (1990): "Contre les épaves", en A. Duval, J.-P. Morel y Y. Roman (eds.), Gaule Interne et Gaule
Méditerranéenne aux IIe et Ier Siécles avant J.-C. Confrontations et Chronologies. Révue Archéologique Narbonnaise Sup. 21: 291-301.

TONIOLO, A. (1991): Le anfore di Altino. Società Archeologia Veneta XIV. Padova.

- (1996): "Anfore", en A.M. Tamassia (ed.), Archeologia di un Ambiente Padano S. Lorenzo di Pegognaga (Mantova): 235-270.

- (2000): Le anfore di Adria (IV-II secolo a.C.). Sottomarina (Ve).

TONIOLO, A. y FAYAS, B. (2002): “Comercio di contenitori di transporto a lungo corso tra Meditarraneo Tirrenico e Mallorca nel III-I secolo a.C.”, en M. Khanoussi, P. Ruggeri y C. Vismara (eds.), L'Africa Romana. Atti del XIV Convegno di Studio (Sassari, Diciembre 2000) vol. 1: 697-710. Roma.

TRINDADE, L. y DIOGO, A.M.D. (1995): “Ânforas romanas de Aljustrel”, Vipasca. Arqueologia e História 4: 11-14.

VAN DEN WERFF, J.H. (1986): "The amphora wall in the house of the porch, Ostia", Bulletin Antieke Beschaving (BaBesch) 61: 96-137. Lovaina.

VÁZQUEZ PAZ, J. (2005): La cerámica romana documentada en la I.A.P “Plaza de la Aviación” de San Juan de Aznalfarache, Sevilla (04/23). Sevilla (Informe Inédito. Delegación en Sevilla de la Consejería de Cultura de la Junta de Andalucía).

VEGAS, M (1975): Novaesium VI. Die augusteischen gebrauchskeramik, Limesforschungen XVI. Berlín.

VIEGAS, C. (2011): A ocupacão romana do Algarve. Estudo do povoamento e economia do Algarve central e oriental no período romano, Estudos \& Memórias. 3. Lisboa, Centro de Arquologia da Universidade de Lisboa / FCT.

ZÉVI, F. (1966): "Apunti sulle anfore romane I. La tavola tipologica de Dressel”, Archaeologia Classica 18: 208-247. 